INTERNATIONAL PHASE OF OCEAN DRILLING (IPOD)

DEEP SEA DRILLING PROJECT

DEVELOPMENT ENGINEERING

TECHNICAL REPORT NO. 12

\title{
DESIGN AND OPERATION OF THE HYDRAULIC PISTON CORER
}

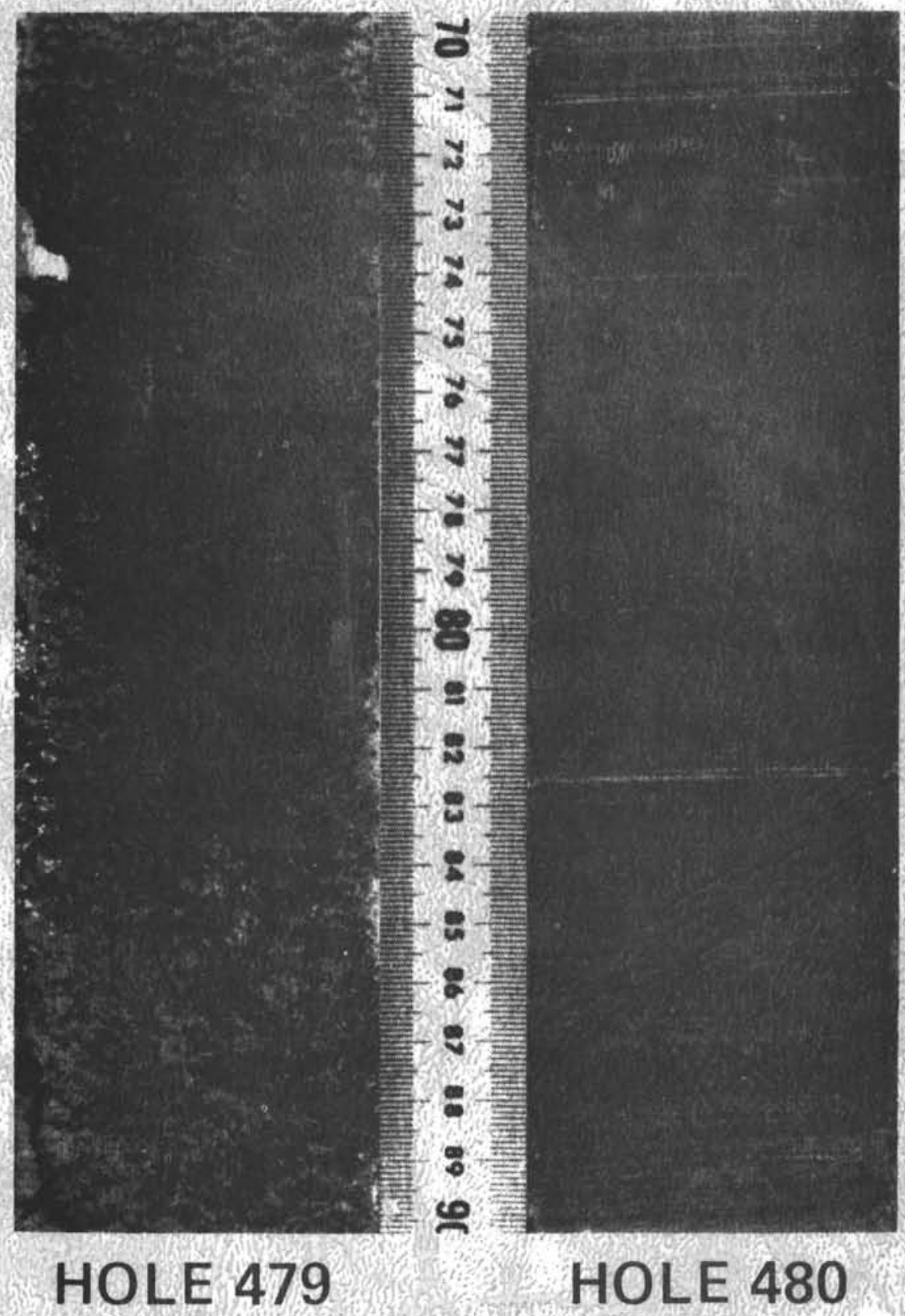

SCRIPPS INSTITUTION OF OCEANOGRAPHY UNIVERSITY OF CALIFORNIA AT SAN DIEGO CONTRACT NSF C-482

PRIME CONTRACTOR : THE REGENTS, UNIVERSITY OF CALIFORNIA 
DISCLAIMER

This report was prepared by the Deep Sea Drilling Project, University of California, San Diego as an account of work sponsored by the United States Government's National Science Foundation. Neither the University nor any of their employees, nor any of their contractors, subcontractors, or their employees, makes any warranty, express or implied, or assumes any legal liability or responsibility for the accuracy, completeness or usefulness of any information, apparatus, product or process disclosed, or represents that its use would not infringe privacely owned rights. 
THE COVER PICTURE

The two cores shown on the cover are from Leg 64, The Guymas Basin. Both cores recovered Quaternary sediments, and despite the great difference in degree of disturbance, the shipboard party concluded that the upper $152 \mathrm{~m}$ is duplicated in the two holes. The following is an excerpt from the shipboard core descriptions:

Site 479, Core 12 Cored Interval: $\begin{gathered}98 \text { to } 107.5 \mathrm{~m} \text { sub-bottom } \\ 100 \% \text { recovery }\end{gathered}$

"Uniform, moderate olive brown (5Y 4/4) muddy diatomaceous ooze, and rare streaks of lighter pale olive (10Y 6/2). Any bedding has been totally disturbed. No evidence of varves, sand or $\mathrm{H}_{2} \mathrm{~S}$ gas."

Site 480, Core 20 Cored Interval: 95 to $99.5 \mathrm{~m}$ sub-bottom $99 \%$ recovery

"Moderate olive brown (5Y 4/4) muddy diatomaceous ooze and pale olive (10Y 6/2) diatomaceous ooze laminae occur together as varve-1ike couplets on a mm-scale. A gray sand layer occurs with a discordant, sharp contact against the varves, but shows no grading. Unconformities and some cross-bedding observed in the varved section."

Core 12, Site 479 was taken using conventional rotary drilling technique. Core 20, Site 480 was taken using the Hydraulic Piston Corer (HPC-15).

(Excerpt from JOIDES Journal

Vol. V, No. 2, June 1979) 
TECHNICAL REPORT NO. 12

\author{
Prepared for the \\ NATIONAL SCIENCE FOUNDATION \\ National Ocean Sediment Coring Program \\ Under Contract $\mathrm{C}-482$ \\ by the \\ UNIVERSITY OF CALIFORNIA \\ Scripps Institution of Oceanography \\ Prime Contractor for the Project
}

May 1983

W. A. Nierenberg, Director

Scripps Institution of Oceanography
M. N. A. Peterson

Principal Investigator and Project Manager

Deep Sea Drilling Project

Scripps Institution of Oceanography 


\section{INTRODUCTION}

This Deep Sea Drilling Project Technical Report No. 12 includes a paper on the design and operation of the Hydraulic Piston Corer authored by M.A. Storms, Wil Nugent and D. H. Cameron. Design analyses and detail drawings are included in an appendix.

The Hydraulic Piston Corer was developed at the Deep Sea Drilling Project in response to a scientific requirement for undisturbed core of the upper unlithified section of the seafloor. Conventional coring practice severely disturbed the soft oozes and clays. The new tool recovered complete and undisturbed cores greatly improving stratigraphic resolution. The device also extended by an order of magnitude, the depth capability of piston coring. Conventional piston and gravity corers were limited to approximately 30 meters of penetration. The hydraulic piston corer, through its repeatable process, has penetrated sediments in excess of 300 meters below the seafloor.

Operational tests of the $4.5 \mathrm{~m}$ Hydraulic Piston Corer conducted on Leg 64 (December 1978-January 1979), obtained an almost totally undisturbed and complete section from a 152 meter hole along the Guaymas slope in the central Gulf of California. The Hydraulic Piston Corer fully penetrated sediments with shear strengths of 1200 grams per square centimeter recovering in excess of $80 \%$ on most cores. Penetration decreased with increasing sediment stiffness. The maximum shear strength of recovered sediment was 3185 grams per square centimeter.

Beginning with Leg 80 (May 1981-July 1981), an improved coring system, referred to as the Variable Length Hydraulic Piston Corer (VLHPC), was utilized. The VLHPC is capable of recovering cores up to $9.5 \mathrm{~m}$ in length. Recovery has averaged more than $93 \%$ with some holes achieving $100 \%$. In addition, an absolute core orientation system was added and a capability to measure heat flow in situ.

Piston coring operations are conducted with the wireline remaining attached to the barrel. This saves the time required to pump down the core barrel and makes for a more efficient coring system.

The VLHPC recovers core in a standard butyrate core liner. The core bit used is a special 11.5" O.D. roller cone core bit with a 3.62 " core throat. Coring must be discontinued when the sediments become too indurated. The VLHPC system is not designed for drilling and coring in hard rock.

A coring system is under development which will be capable of continuing the penetration on to basement. This coring system, called the Extended Core Barrel (XCB), will be compatible with the VLHPC bottom hole assembly. Thus, the XCB will continue coring from that point at which VLHPC coring operations are halted without necessitating a trip of the drill string. 


\section{ACKNOWLEDGEMENTS}

The Hydraulic Piston Corer (HPC) was designed and developed by Mr. M. A. Storms of the Deep Sea Drilling Project's development engineering group. The HPC proved to be a highly successful adaptation of rotary coring capability to the taking of high quality piston cores. The concept of a high-speed hydraulic ram/corer powered by rig pump pressure has extended the reach of high quality piston cores from 30 to 300 meters below the seafloor of the deep ocean. This capability is contributing to improved understanding of the earth's past climate and to geologic processes reaching back some 15,000,000 years. Mr. Wil Nugent contributed to the system through mathematical analysis and design. Mr. D. Cameron assisted with fabrication and sea trials of the HPC. Mr. S. T. Serocki, Chief Development Engineer, provided general direction of the work. Overall supervision was by Mr. F. C. MacTernan, Deputy Project Manager.

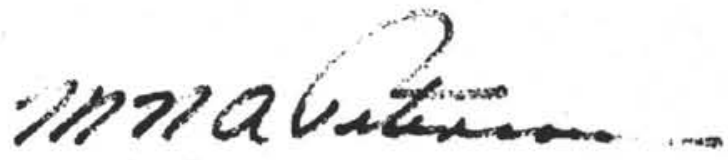

M. N. A. Peterson

Principal Investigator

and Project Manager

IPOD/DSDP/SIO 
CONTENTS

I HYDRAULIC PISTON CORING - A NEW ERA IN OCEAN

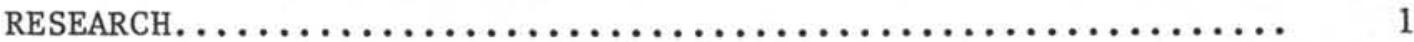

M. A. Storms, W. Nugent, D. Cameron

II HYDRAULIC PISTON CORER - LEG 64 OPERATIONAL REPORT ......... 25

D. Cameron

III APPENDIX A - HYDRAULIC PISTON CORER ANALYSIS . . . . . . . . 33

W. Nugent

APPENDIX B - HYDRAULIC PISTON CORER ORIFICE ANALYSIS........ 53

W. Nugent

APPENDIX C - HYDRAULIC PISTON CORER STRUCTURAL ANALYSIS.......

W. Nugent

APPENDIX D - HYDRAULIC PISTON CORER THREADED CONNECTION

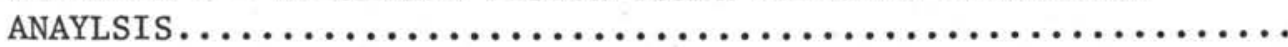

W. Nugent

APPDENDIX E - HYDRAULIC PISTON CORER RETRIEVAL FORCE

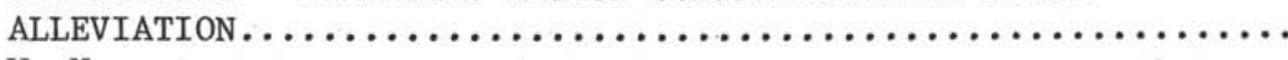

W. Nugent

APPENDIX F - HYDRAULIC PISTON CORER LANDING IMPACT......... 93

IV VARIABLE LENGTH HYDRAULIC PISTON CORER PARTS LIST AND

ASSEMBLY DRAWINGS .............................. 109 


\section{HYDRAULIC PISTON CORING}

\section{LIST OF FIGURES}

1. Hydraulic Piston Corer............................. 11

2. Hydraulic Piston Corer Performance Curve.................. 12

3. Scale Model Load Test.............................. 13

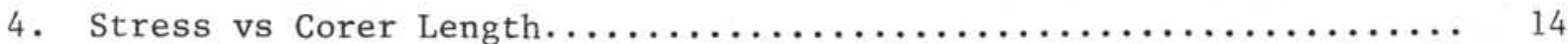

5. Hydraulic Piston Corer Operational Sequences............... 15

6. DSDP Hydraulic Piston Corer Test...................... 16

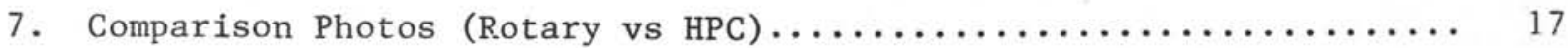

8. Prediction for 9.5 m Hydraulic Piston Corer................ 18

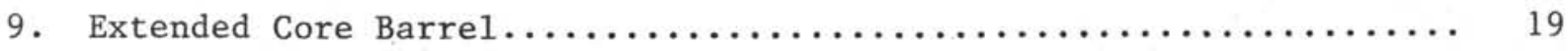

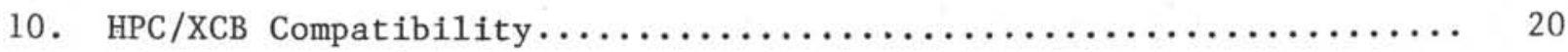

\section{LIST OF TABLES}

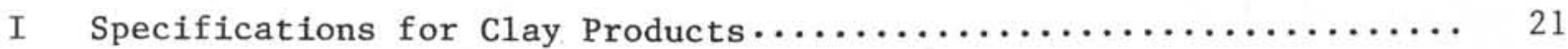

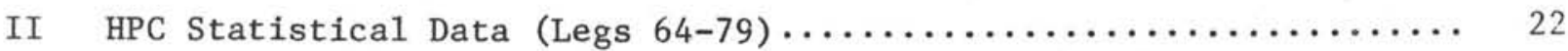

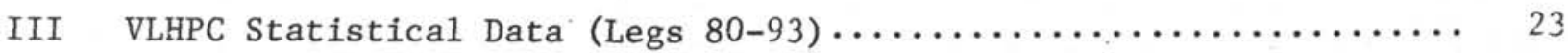




\author{
HYDRAULIC PISTON CORING \\ by \\ M. A. Storms \\ Wil Nugent \\ D. H. Cameron
}

A NEW ERA IN OCEAN RESEARCH

\title{
ABSTRACT
}

In December of 1978, the Deep Sea Drilling Project, International Phase of Ocean Drilling, deployed the first hydraulically actuated piston corer. This coring system utilized a hydraulic piston principle. Fluid was pumped through the drill pipe, activating a piston driven core barrel which was ejected into the sediment at the rate of approximately 20 feet per second. This extremely high penetration rate effectively decoupled the core barrel from the heave induced vertical motion of the drill string. On completion of each coring operation, the core barrel assembly was retrieved by wireline. The core bit was then "washed" down to the next coring point where the piston coring procedure was repeated. Operational tests conducted in 865 meter water depth during Leg 64 obtained an almost totally undisturbed and complete section from a 152-meter hole along the Guaymas slope in the central Gulf of California. Variations in climate, productivity and circulation for more than 250,000 years were recorded. This paper describes the analysis, design, testing and field operation of the hydraulic Piston Coring System.

Deep Sea Drilling Project

The Deep Sea Drilling Project (DSDP) began coring in August of 1968 . Funding and direction was given by the National Science Foundation's (NSF) Ocean Sediment Coring Program. Their mandate was to increase man's knowledge of the earth's development through an ambitious ocean sediment coring program. The Prime Contract for the Project was executed in 1966 between NSF and the University of California (UC) Board of Regents. Scripps Institution of Oceanography, an integral part of the UC system, was to be responsible for management of the Project. Global Marine Inc. (GMI), through a subcontract with Scripps, was to provide the drilling vessel and crew.

Major oceanographic institutions of the United States were called upon to support the proposed drilling program by contributing to the planning of the scientific objectives. The resultant organization became known as "Joint Oceanographic Institutions for Deep Earth Sampling (JOIDES". These institutions for Deep Earth Sampling (JOIDES)". These institutions continue to provide scientific guidance for the drilling effort.

International Phase of Ocean Drilling

Prompted by the vast scientific and technical successes of the first seven years, the Project increased the scope of the coring program to include even 
deeper penetrations into the ocean floor. International interest in the Project was increasing. Several foreign scientific institutions, excited by past scientific results and confident of future successes, were interested in becoming members of JOIDES. These institutions were willing to contribute financially to the Project in exchange for a greater role in the scientific planning. In 1975, the "International Phase of Ocean Drilling", known as IPOD, was born. IPOD was an initial three-year Deep Crustal coring Program supported both scientifically and financially by the governments of France, Germany Japan, England and Russia.

\section{D/V GLOMAR CHALLENGER}

The GLOMAR CHALLENGER, with its unique coring procedures, has 1ong been recognized as a major technical achievement in its own right. The 10,500 metric ton drillship utilizes an advanced on-board computer and dual bow and stern thrusters to dynamically position itself. The CHALLENGER has operated as far north as $76^{\circ}$ latitude; as far south as $77^{\circ}$ latitude and has the capability to maintain its station in 30-knot winds and 7-10 foot seas. Similar to conventional drillships, the vessel incorporates a 43-meter derrick amidship with a hookload capacity of 450 metric tons and can deploy a $7000 \mathrm{~m}$ drill string. The CHALLENGER utilizes an automatic pipe racker capable of handling 7,300 meters of 5-inch S-135 drill pipe, and is equipped with a drill pipe heave compensation system.

Most coring operations are conducted in very deep water and all sites are carefully screened to ensure that there is no possibility of encountering gas or hydrocarbons. For these reasons no riser or blow prevention equipment is used. Circulation while coring is provided by two National 1600 mud pumps and consists of seawater without return circulation. Core barrels are retrieved by wireline utilizing a coring winch equipped with up to $7900 \mathrm{~m}$ of 6 x 16 wire rope. Well equipped shipboard scientific laboratories are utilized to conduct comprehensive core analyses.

\section{SCIENTIFIC OBJECTIVES}

The development of the Hydraulic Piston Corer (HPC) was in response to a basic need in the science community to recover high quality cores, particularly in soft sediments. The upper 200 meters of the sedimentary column were highly disturbed during the rotary drilling process. Attempts at detailed disciplines such as paleoceanography, paleoclimatology, magnetostratigraphy and high resolution stratigraphy were all but impossible. It was apparent that some means to overcome the limitations of rotary drilling in unlithified sediments was required. Piston cores historically have provided a means to distinguish events recorded in sediments as little as one thousand years apart; events that are homogenized by rotary drilling. Oceanographic vessels were routinely taking piston cores of mudline sediments. These "conventional" piston coring systems, however, were limited to just a few tens of meters of the surface material, lacking the capability for any significant penetration.

At the request of the science community, the Deep Sea Drilling Project undertook the development of a wireline retrievable piston coring system. This new coring system was to make use of all the advantages of a "conventional" piston coring system yet be compatible with the GLOMAR CHALLENGER'S coring operation and have the capability to penetrate up to 200 meters below the 
ocean floor.

\section{PROTOTYPE DESIGN}

In responding to the scientific mandate for a CHALLENGER piston corer, a set of design and operational criteria were compiled which would govern the development of this new coring system. The corer was to be operated hydraulically; the driving force for the coring system would be the circulating pumps aboard the GLOMAR CHALLENGER. These pumps would be used to pressure the drill string. When released, the energy would drive the core barrel into the sediment at a high rate of speed (Figure 1). Actuation pressure was limited to the 2800 psi operating pressure of the circulating system. The tool was required to be wireline retrievable through 5" drill pipe with a nominal 4.12 inch inside diameter. Scientific preference dictated the nominal 2.43 inch $(6.20 \mathrm{~cm})$ core size.

Several areas of concern were investigated including potential column and bending loads imposed upon the core barrel itself; what lateral support could be expected from the formation and what penetration rate would have to be achieved to effectively decouple vessel motion from the tool during the coring operation.

It was recognized that occasionally the coring instrument would be ejected at a high velocity into sediment with little or no resistance. For this reason a dampening system had to be incorporated at the end of the stroke, to lower impact forces.

The Hydraulic Piston Corer design criteria was based on using equipment and techniques already developed, and proven successful, in deep sea drilling operations aboard the GLOMAR CHALLENGER. In addition, a review of advanced conventional piston coring operations was conducted with particular emphasis on sediment stiffness and shear strengths encountered in these tests. The information on subsurface foundation material densities and shear strengths compiled in DSDP Technical Report No. 9, dated September 9, 1976, was included in this review.

The design objectives were:

* Assess the friction coefficient of the subsurface material(s) entrained in the Hydraulic Piston Core (HPC) tool, at various penetration velocities, consistent with shipboard pumping capacity.

* Develop mechanization schemes in support of the HPC design.

* Prepare a hydraulic analysis, determine orifice sizes, and flow conditions compatible with the pumping system.

* Establish structural guidelines to ensure safety, repeatability of performance, and fabrication capability using immediately available materials.

* Implement safeguards such as snubbing to reduce end stroke impact. 
* Develop procedures for assembly and handling of the HPC compatible with rig floor operations.

\section{ANALYTICAL ANALYSIS}

Frictional resistance to coring was recognized to result from sediment shear, internal drag resistance of material being entrained in the corer tube, choking or overspilling at the leading edge of the tool, and external friction. Efforts were directed to the development of a single constant which could be used to characterize the total resistance. The shipboard rig pump pressure and available annulus area provided the force on the core barrel column. The displacement volume of the rig pump provided the core barrel penetration rate. A discharge orifice controlled the discharge rate of the seawater from the lower chamber, and established the maximum achievable corer barrel penetration rate.

An input force is applied by pressure on the piston. The frictional resistance consisted of mechanical sliding friction and the frictional resistance or drag due to the rate at which the hydraulic piston corer penetrated into the sediment.

The sediment was characterized as an emulsified substance rather than a slurry containing particles of discrete size suspended in a fluid. These sediments could be ooze and/or unlithified bases with shear strengths ranging from 100 to 300 grams per square centimeter. The particle grain size was small, less than $0.5 \mathrm{~mm}$ average diameter and greater than $50 \%$ seawater saturated.

These conditions were recognized to be outside the bounds of discrete particles, and not absolutely fluidic. The substance was similar to a dough which flows as a homogeneous mass, distinct from a turbulent fluid.

It was essential that the corer penetration velocity be controlled. Too fast a penetration rate could cause structural damage to the corer itself or induce core disturbance such as liquifaction. Too slow a penetration rate would fail to decouple the corer from the drill pipe motion, again inducing excessive core disturbance.

With these restraints in mind a velocity requirement was selected in the range of 20 feet per second and decaying not below ten feet per second during the entire coring operation.

The analysis was based on 2000 psi pump pressure and greater than 350 gallons per minute pump delivery capability to the bottom of the drill string. No allowance for compressibility of fluid was taken into account. Since the pump pressure acting on the annulus produces the coring force, the pump displacement (flow rate) produces the corer velocity. The discharge orifice, required for venting seawater from the lower chamber, was used to control the velocity of the corer. For analytical purposes it was assumed that the upper and lower chamber volumes were approximately equal. The effective pressure which discharges fluid through the orifice then becomes the net pressure, or the force on the annulus less the sediment resistance. 
Other pressure losses which may occur at the discharge orifice were not considered in the analysis.

The discharge orifice is important in controlling the rate of corer penetration. For a given pressure and penetration resistance, presuming that sufficient fluid flow is available to maintain the pressure, the corer tube will travel at a velocity dependent upon the volume rate of discharge through the orifice.

The characteristics of flow through an orifice are well defined, but the behavior of the sediment when producing resistance to the force on the corer piston requires some definition, particularly for variations in sediment compaction, geology, and the depth of penetration desired.

Although the various sediment types behave neither as a fluid nor as a series of discrete particles, it was recognized that they do have a common characteristic during coring, that is the frictional or drag resistance, which is dependent upon the equation $\tau=\mu \mathrm{dv}$ from which the viscosity $(\mu)$ of a homogenous substance may be derived when the shear stress is known.

It was assumed that the sediment was "fractured" at an infinite number of diametrically opposite locations along the circumference of the corer during penetration. Knowledge of the sediment shear strength and density allowed an estimate for a friction coefficient (f). Viscous flow conditions were assumed and the characteristic drag expression $D=\frac{1}{2} \mathrm{pv}^{2} \mathrm{fX}($ area), where $v=$ penetration velocity and $p=$ the mass density of the sediment, were used to define the drag resistance for each successive foot of core barrel penetration. This analytical approach connected the behavior of the material to be cores with the energy available to operate the hydraulic piston corer and the desired rate of penetration.

The drag term represented the sediment resistance to coring, and was a function of velocity. In this approach a theoretical velocity exists prior to establishing equilibrium between the driving force and the resisting force. When penetration resistance equals the force available the piston corer stops (Figure 2). Using these elementary approaches, the performance characteristics of the HPC have to date been predictable within reasonable limits.

A Fortran program was compiled which provided HPC operating forces and computed the working stress level at the critical sections of the piston corer column. This program enabled input changes to sediment shear strength, hydraulic pressure and/or shear pin release, effective piston area, side hole support, and penetration velocity to simulate actual operational conditions.

The computer generated output showed good correlation with the results from coring operations in sediment with shear strengths up to $1200 \mathrm{~g} / \mathrm{cm}^{2}$ $\left(2457 \mathrm{lb} / \mathrm{ft}^{2}\right)$. Experience in operation confirmed that the hydraulic piston corer performed well in water depths of $3500 \mathrm{~m}(11,483 \mathrm{ft})$, and in sediment shear strengths of $2,513 \mathrm{~g} / \mathrm{cm}^{2}\left(5,146 \mathrm{bb} / \mathrm{ft}^{2}\right)$ the piston velocity was reduced to zero. Total stroke indication was not observed, although $3.26 \mathrm{~m}$ $(10.7 \mathrm{ft})$ of core was retrieved. 
Operational results relating shear strength, hydraulic pressure and the length of core recovered, were used to develop an empirical coefficient; which accounted for the observed increase in resistance to coring, with increase in depth of penetration. These sample data were included in an analysis, which yielded the mean values for shear strength, length of core recovered, and applied pressure during coring.

Figure 2 is a data plot predicting the performance of 4.4 meter coring tool used on Leg 68. A sediment drag coefficient was developed using an expression for a uniform two-dimensional flow, which applies the effects of sediment shear strength and mass density.

\section{STRUCTURAL COLUMN}

Deflection of the HPC column, resulting from penetration on sloping faces, or offline impact against rock formation, was included as a constraint and analyzed.

This analytical procedure enabled the stresses to be calculated at critical sections, i.e. thread undercuts, etc., along the corer barrel by predicting the deflection and calculating the bending moment.

Additional analysis and scale model tests were conducted to determine the behavior of the upper shaft and the piston rod, for various lengths of HPC configuration. The corer barrel is unsupported when extended beyond the drill bit, but the upper shaft and the piston rod are constrained against deflection with the drill collar assembly. A moment distribution analysis and a static load test on a scale model (Figure 3) showed good correlation.

The result indicated that the maximum rig pump pressure could be applied on the HPC piston configuration, and that precautions should be taken in instances where hole drift angle or excessive side loads could be encountered. A preliminary computer program was compiled, to generate parametric data relating stress and coring length, to various differential side forces applied midway between the cutting shoe, and the drill bit support on the core barrel. Figure 4 presents the results, which indicate the potential to core into $1200 \mathrm{~g} / \mathrm{cm}$ sediment and retrieve $30 \mathrm{ft}(9.5 \mathrm{~m})$ cores, using core barrels fabricated of $4130 \mathrm{CD}$ steel.

\section{OPERATION}

The Hydraulic Piston Corer consists of two basic assemblies. An inner assembly which remains stationary during activation of the tool and an outer assembly, which scopes down along the inner assembly during tool operation (Figure 5).

When the tool is in the closed position (ready to run), shear pins secure the outer assembly to the inner assembly.

The tool is lowered down the drill pipe on the wireline until the top sub lands in a special head sub located in the bottom hole assembly. Circulation is then initiated. As the drill string begins to pressurize, the seals around the top sub effect a seal in the head sub. Pressurized water is 
directed through the top sub and shaft, and out the lower end of the inner seal sub into the annulus between the inner and outer seal subs.

The pressure increases until the pins shear; then the outer seal sub (attached to the outer assembly) is forced down and away from the inner seal sub (attached to the stationary shaft and piston rod). As the outer body penetrates the mud, the piston head remains stationary, causing the fluid above to be vented to the annulus. At the end of its stroke the inner seal sub, which seals along the outer body, uncovers a set of control orifices drilled through the vent sub body wall. The pressurized fluid can then vent through the orifices to relieve the pressure in the drill string and give the rig floor an indication that the corer has fully stroked. The core barrel is then retrieved, the core bit is washed down to the next coring point, and the sequence begins again.

\section{SHORE BASED TESTING}

Prior to field deployment a comprehensive shore based performance test was conducted. The objectives of this test were to verify the mechanical actuation, operation, and structural integrity of the hydraulic piston corer. Variables included sediment shear strength, flow rate, and shear pressure, i.e. that pressure at which the barrel releases and begins to move into the sediment.

Energy for the test system was supplied by a BJ Pacemaker "Duplex" cementing unit. This unit could supply the minimum flow rate of $350 \mathrm{gpm}$ at 2000 psi required for the test.

Four different mixes of clay products were purchased to provide several variations in stiffness for the test. Table I shows the physical properties and compositions of the products used. For ease of handling, the clay was put into standard "Burke" fiber tubes normally used for pouring concrete columns. The tubes used were 12.0" inside diameter by .225" wall (regular) and were $15^{\prime}$ in length. To support the Burke tubes during handling, a hanger system was fabricated using 16" casing. This "holder" allowed easy insertion and retrieval of the clay filled tubes into and out of the test hole. The test hole was 46-feet deep and lined with 24-inch diameter casing. The piston corer itself was handled with the aid of a 3-ton electric chain hoist located directly over the hole.

An instrumentation system was developed to determine the average penetration velocity of the tool. A pressure transducer was put in line from the BJ Pacemake pump to the test assembly. Input from the transducer was fed as an analog signal into an 8-channel multiplexed data acquisition system connected to an IBM 1130 computer. Figure 6 shows a typical pressure vs time curve obtained during a full sequence of tool operation. From this curve the shoot off point and end of stroke venting can be taken. Knowing the distance traveled and elapsed time, an average penetration velocity was determined. Test data collected with the instrumentation system compared favorably with the previously calculated theoretical data. 
Sea Trials were conducted on the Hydraulic Piston Corer in December 1978 and January 1979, during Leg 64. The new tool was run a total of 52 times on three sites in the Guaymas Basin of the Gulf of California.

At Site 480 (water depth $657 \mathrm{~m}$ ), 32 cores were taken to a subbottom depth of 152 meters with an average of over $80 \%$ recovery (we1l over $90 \%$, if two low recovery cores are excluded). Finely laminated sedimentary sections ranging from soft mud to very firm diatomaceous ooze were recovered virtually undisturbed. The singular success of the HPC on this site is underlined when compared to the poor quality of cores recovered in the upper $100 \mathrm{~m}$ through rotary coring at Site 479 , only $6.8 \mathrm{~km}$ to the southwest (Figure 7 ). Only two cores had little or no recovery. On several of the lower depth runs the core liners returned cracked or partially collapsed. This is believed to have been caused by pull-out suction created when retrieving the HPC from increasingly stiff sediments. The recovery was still good and undisturbed except for the short lengths of liner collapse.

The supply of shear pins was depleted after the numerous runs at Site 480 , so for the 16 runs at Site 481 (water depth $2016 \mathrm{~m}$ ) new pins were fabricated from $3 / 16 "$ brass brazing rod. Sixty four per cent of the $52.25 \mathrm{~m}$ sedimentary column cored was recovered, although six cores, including the last two, recovered over 90 per cent. The intermittently low and high recovery may have been due either to possible wide variations in the shear strength of the new pins, or in the sediment type (e.g., sandy layers.) The latter seems probable since two of the low recovery intervals were recored with the same results. The sediments recovered were, again, undisturbed. The core liners did not collapse or crack on any of these runs.

Throughout the tests, routine maintenance on the HPC consisted of replacing seals as needed and complete breakdown and redressing between sites. The internal seals could not be inspected routinely but were still operable when replaced between sites. The external top sub packing was lost or damaged quite frequently during the earlier runs, but lasted much longer (10 runs) when the retrieval rate was slowed from 300 meters/min to 100 meters/min. Being one-way seals, they tended to flare out and grab at each tool joint if the HPC was retrieved too quickly.

As the rig crew became familiar with handling the HPC, the turnaround time on deck was trimmed to 20 minutes when using a single lower core barrel section. It would have been even faster had they been able to alternate between two lower sections, but one was lost on Site 477A. The time between cores still was only slightly longer than for standard coring operations.

\section{TECHNICAL IMPROVEMENTS}

The objective of developing a capability to recover $9.5 \mathrm{~m}$ undisturbed cores through the $13 \mathrm{~cm}$ (5-inch) drill pipe was not abandoned. An assemblage of components were designed with the purpose of configuring $9.5 \mathrm{~m}, 8 \mathrm{~m}$, $6.5 \mathrm{~m}, 5 \mathrm{~m}$, and $3.5 \mathrm{~m}$ hydraulic piston corer units by rearrangement of common elements adapted to a single seal-sub within the drill pipe. This unit, designated as the Variable Length Hydraulic Piston Corer (VLHPC), enables coring to be accomplished over a wide range of sediment formations to the limit 
of the shipboard rig pumping capacity (Figure 8). To date there has been exceptional success with VLHPC operations. After the initial runs, the drill crew handled the entire operation. The VLHPC does not require extensive redressing between runs, and the turnaround time on deck takes about five minutes. The features of this simplistic design approach have been projected into future designs to develop extended coring capability into stiffer formations.

The available force in deep ocean hydraulic piston coring decreases slightly as the corer barrel extends. In the computer program, the resisting force produced by corer penetration is a function of velocity. When the plot of the product of velocity and effective drag coefficient intersects the curve produced as a function of rig pressure and piston area, the corer stroke is assumed to be arrested. The results from operations have validated the analytic procedure within the range of present usage.

\section{ABSOLUTE CORE ORIENTATION}

The ability to recover undisturbed soft cores without rotating led quite naturally to a request from the scientific community to develop a means of preserving the downhole azimuthal orientation of the cores. This has been achieved by "piggybacking" a Kuster single-shot survey instrument onto the VLHPC. The Kuster tool is actually incorporated into the sinker bar string which latches onto the VLHPC Top Sub. The Kuster unit essentially consists of a transparent compass and reference line overlaying a film disc, a battery operated delay timer, a magnetic sensor, and a light source. An orientation line on the core liner is aligned with the reference line within the Kuster unit. When the VLHPC is landed in the drill string, the Kuster tool is positioned within a special non-magnetic drill collar. The sensor detects the change in the magnetic field and activates the delay timer which, in turn, activates the light source to take a picture of the compass and reference line. The film is later developed to reveal the angle between magnetic north and the reference line.

\section{OPERATIONAL PERFORMANCE}

The original version of the Hydraulic Piston Corer (HPC) was successfully operated aboard the D/V GLOMAR CHALLENGER from December 1978 until May 1981. Its successful performance immediately led to the development of its successor, the Variable Length Hydraulic Piston Corer (VLHPC). This highly improved version has now been deployed in the field for over a year with impressive scientific results. Statistical data for both versions of the HPC can be found in Tables II and III. The application of this new coring technology to the field of earth sciences has unquestionably been a success. Expansion to areas such as geotechnical research and engineering may have even wider reaching ramifications.

Efforts are now underway to develop a coring system which can take over when the HPC system has reached its limitations. This "extended" core barrel ( $\mathrm{XCB}$ ) shown in Figure 9, will be designed to drill down to and into basement, without requiring a pipe trip or change of the HPC bottom hole assembly. The compatibility of these two coring systems is shown in Figure 10. 
The Deep Sea Drilling Project (DSDP) Hydraulic Piston Corer (HPC) was developed in response to a major scientific need to recover undisturbed cores from the deep ocean. The technical success of the HPC quite naturally led to an improved successor known as the Variable Length Hydraulic Piston Corer (VLHPC). Hydraulic Piston Coring has been in operation aboard the GLOMAR CHALLENGER for over four years. The scientific rewards are too numerous to mention. DSDP expeditions centering around the use of the hydraulic piston corer have proven to be major successes. The routine recovery of complete geological sections with little or no disturbance has given rise to many new disciplines within the field of marine geology. These new or expanded fields of study are enabling earth scientists to make quantum leaps in their understanding of the earth and its oceans. The potential of this new technology and its contribution to the advancement of earth science research will probably not be fully determined for many years to come. 
Figure 1

HYDRAULIC PISTON CORER

CONCEPT

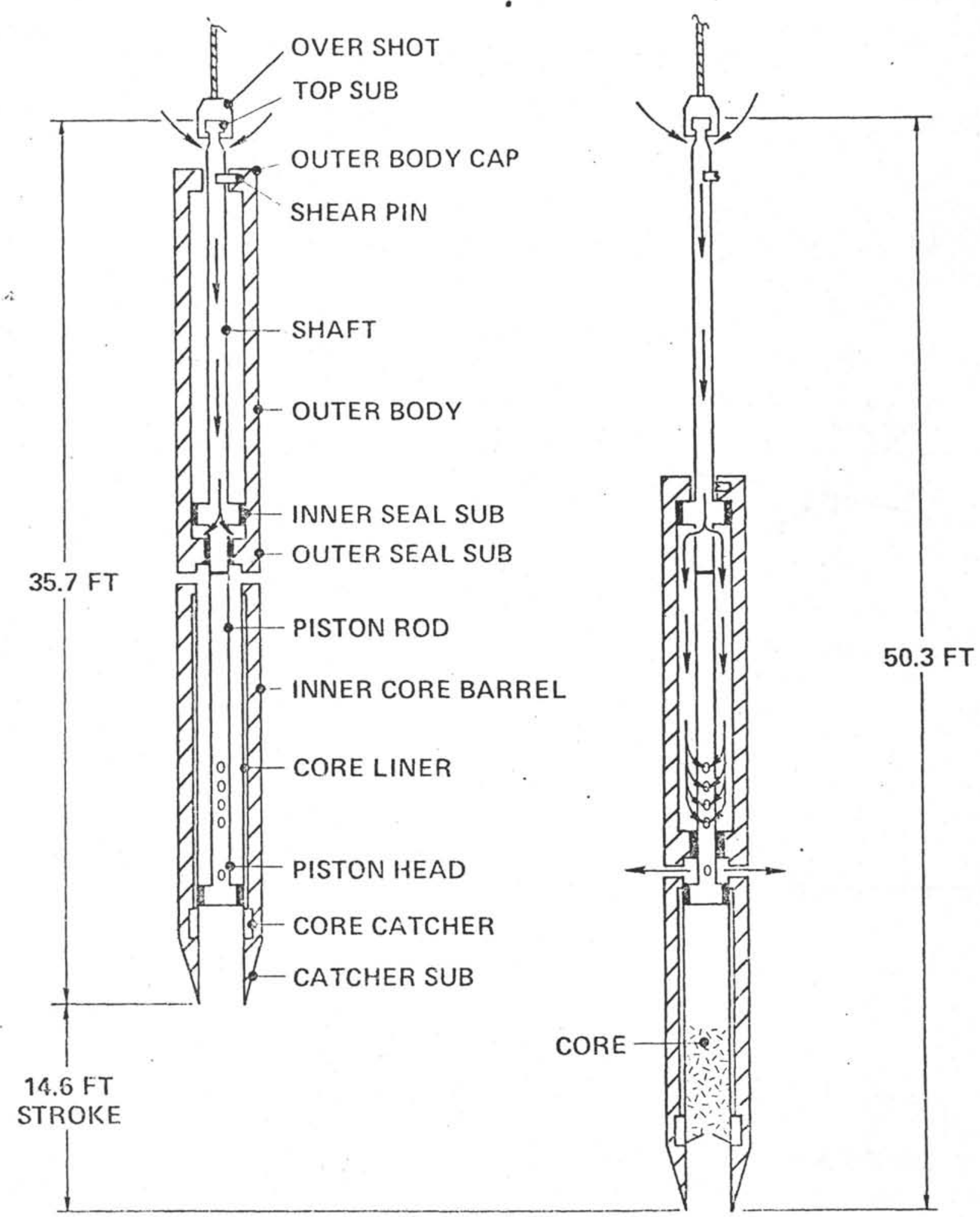


Figure 2

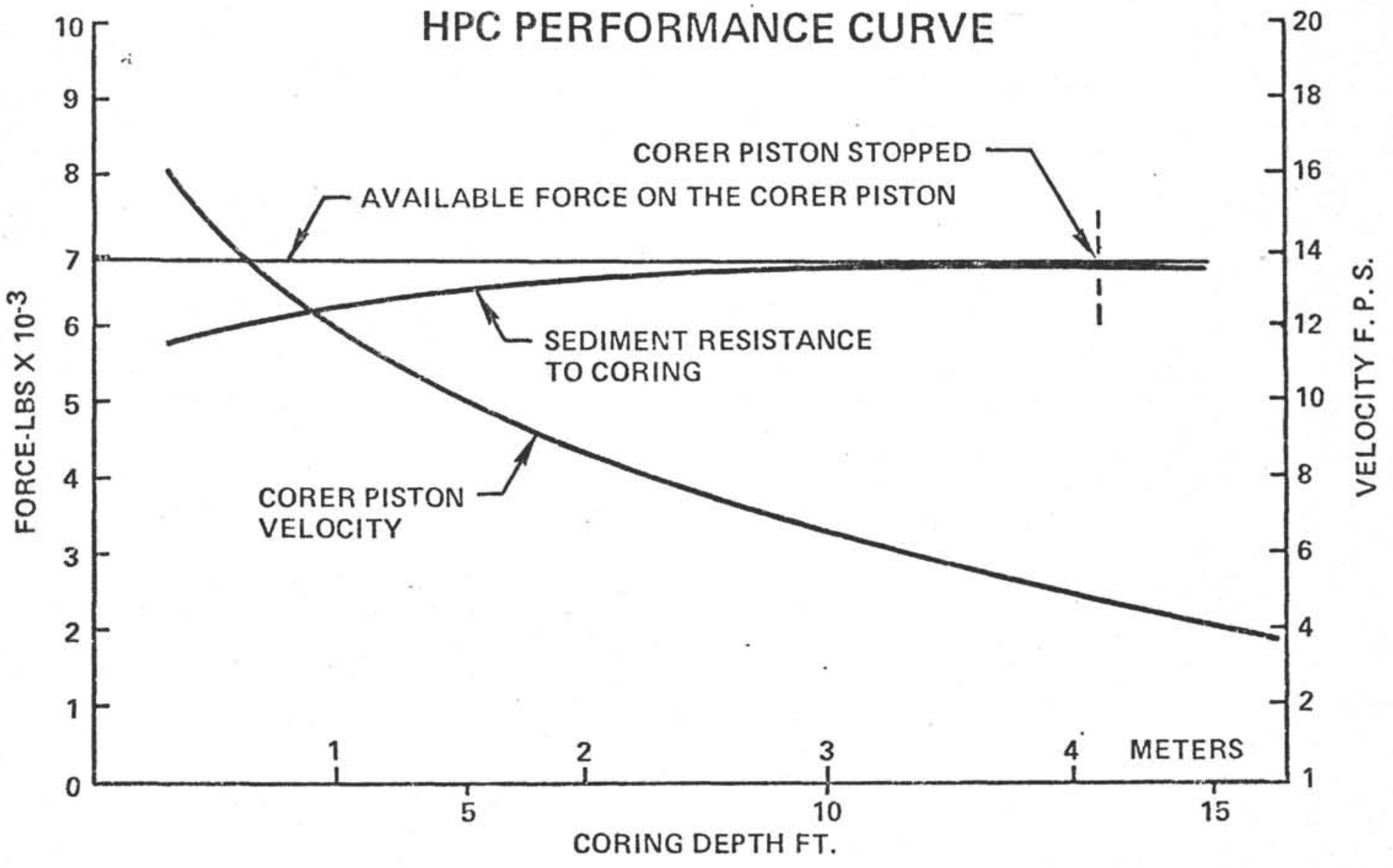


Figure 3

SCALE MODEL LOAD TEST
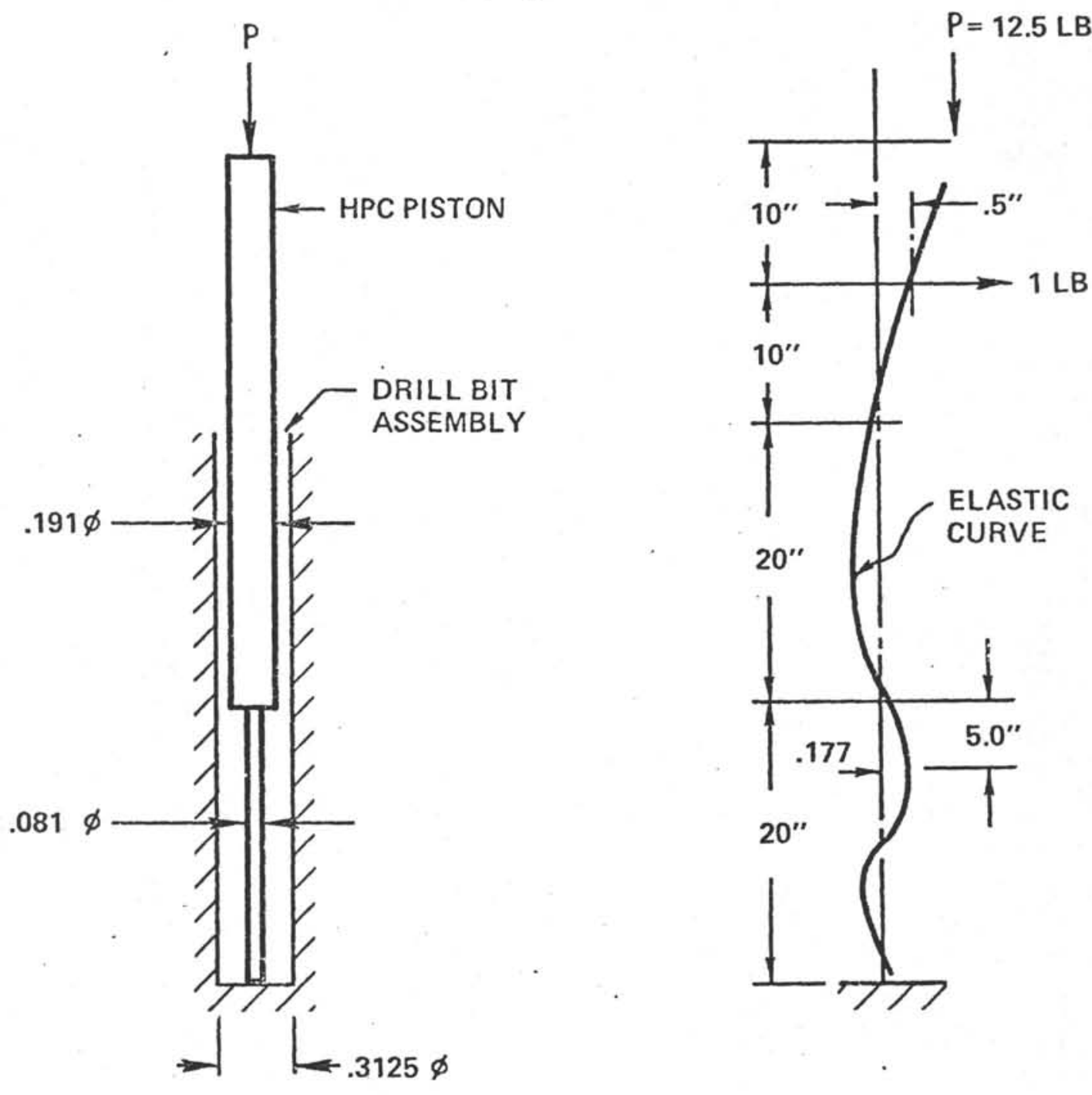

FROUDE SCALING

SCALE FACTOR $\gamma=11$

FORCE FULL SCALE $=\gamma^{3}$ MODEL SCALE

$=12.5(11)^{3}$

AXIAL FORCE $\quad=16,637.5 \mathrm{LB}$

NO SIDE FORCE 
Figure 4

\section{STRESS VS CORER LENGTH}

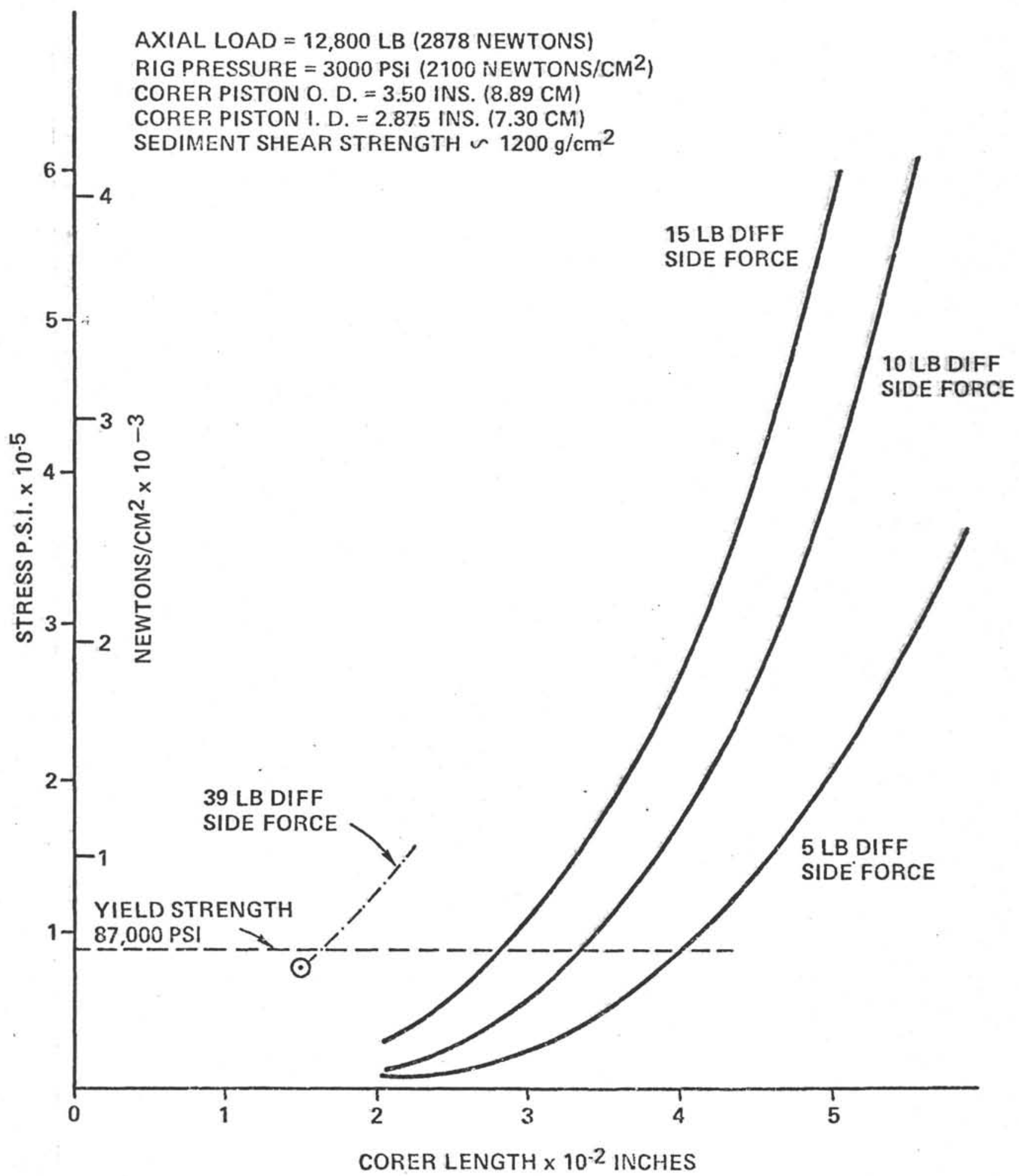


DEEP SEA DRILLING PROJECT

HYDRAULIC PISTON CORER (VLHPC)

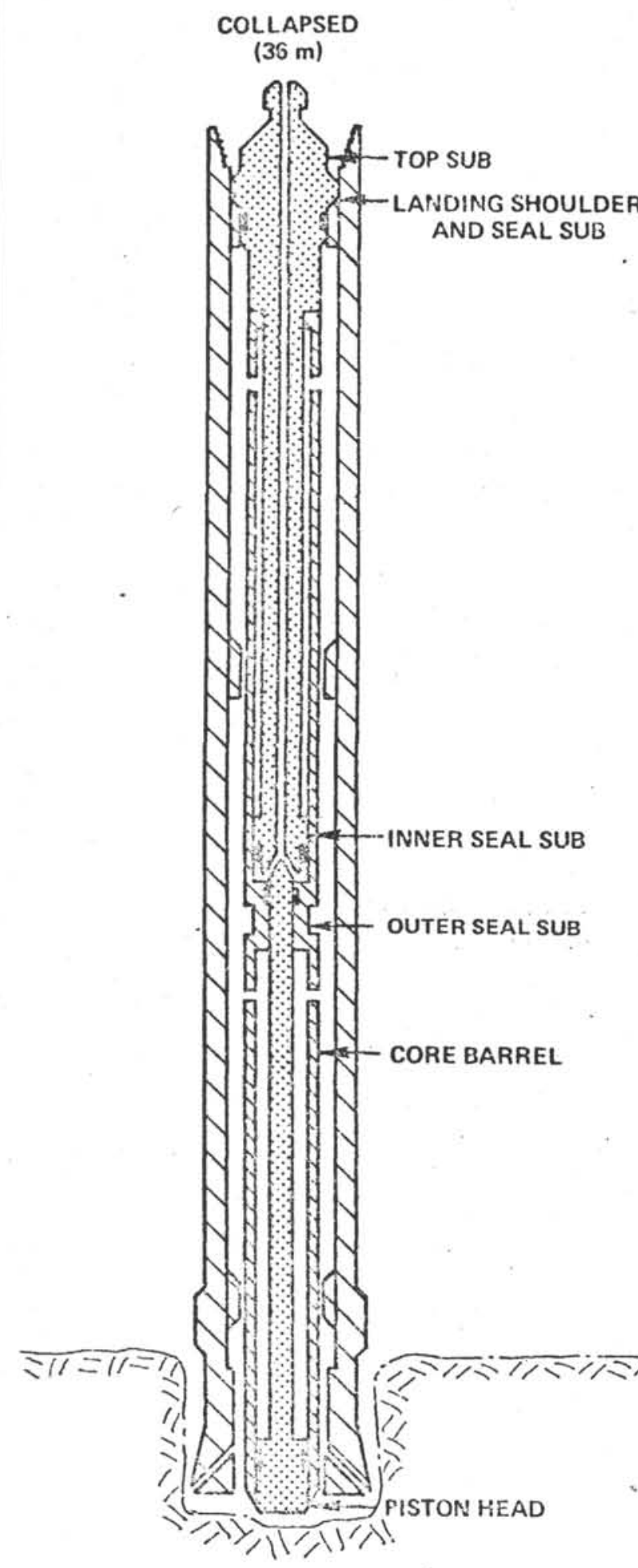

EXTENDED

(50 m)

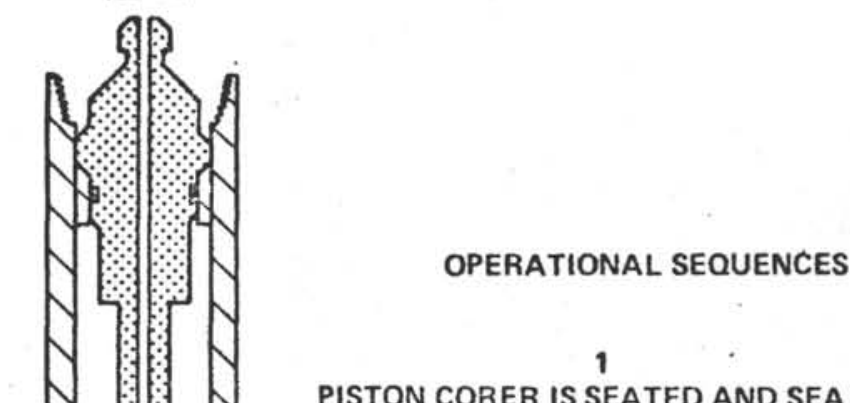

PISTON CORER IS SEATED AND SEA WATER IS PUMPED AT 350 GPM to INITIATE ACTION.

2

LOCKING PINS SHEAR AT A MAX. 2800 PSI THE OUTER SEAL SUB THEN DRIVES THE CORE BARREL INTO THE FORMATION AS FLUID ABOVE THE PISTON HEAD IS VENTED.

3

AT THE END OF THE STROKE DAMPENING PORTS ARE UNCOVERED WHICH VENT THE PRESSURE FLUID AND DECELERATE THE CORE BARREL.

4

RIG FLOOR SEES DROP IN PUMP PRESSURE AS AN INDICATION CORER HAS FULLY STROKED.

5

CORE BARREL IS RETRIEVED. BIT IS WASHED DOWN TO NEXT CORING POINT. PROCESS IS REPEATED UNTIL FORMATION BECOMES TOO INDURATED. 
Figure 6

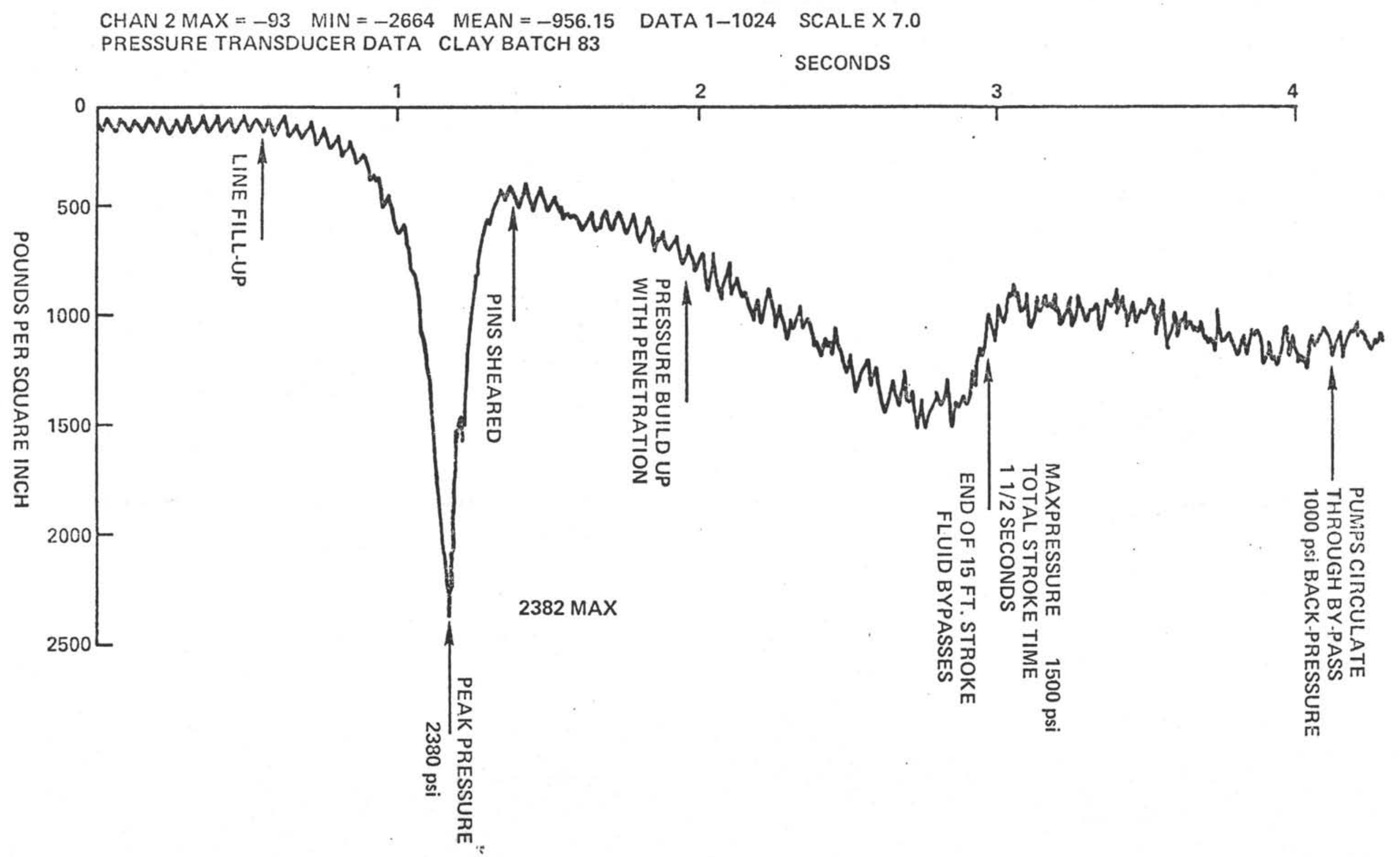


Figure 7

\section{COMPARISON PHOTOS ROTARY CORING VS HYDRAULIC PISTON CORING}

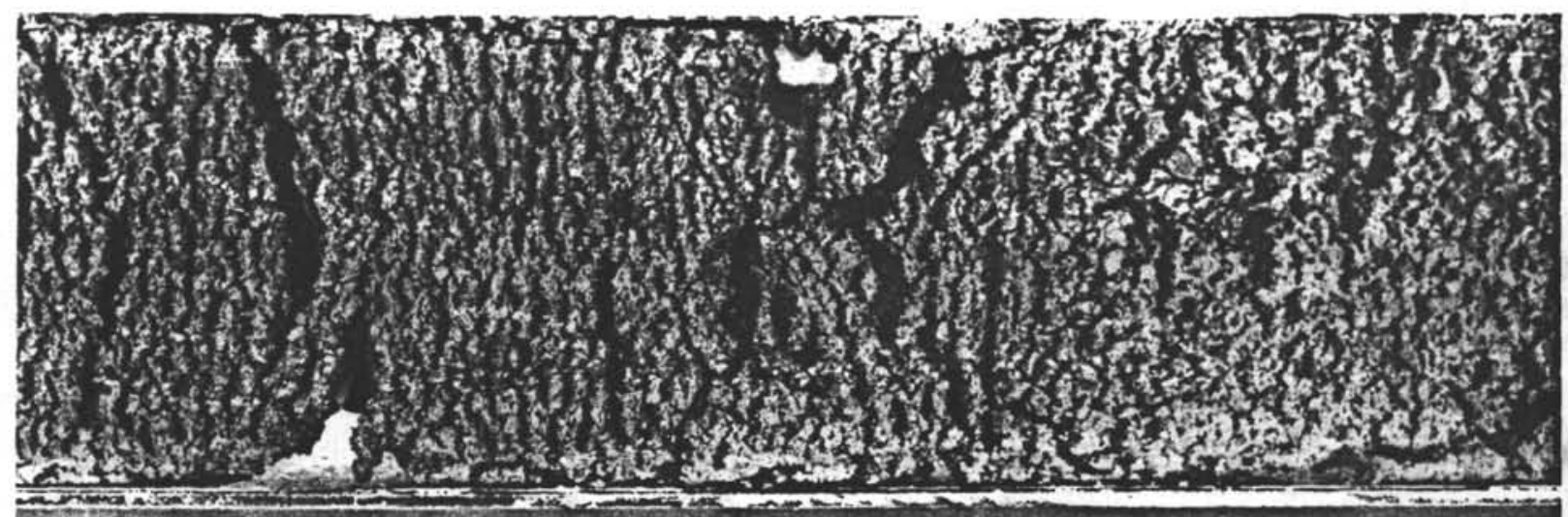

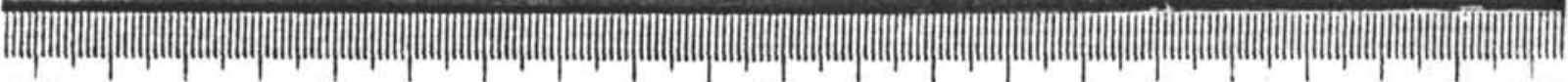
$\begin{array}{lllllllllllllllllllllllllll}70 & 71 & 72 & 73 & 74 & 75 & 76 & 77 & 78 & 79 & 80 & 81 & 82 & 83 & 84 & 85 & 86 & 87 & 88 & 89 & 90\end{array}$ 

\section{STANDARD ROTARY CORE}

HOLE: 479 CORED INTERVAL: 90.0-107.5 m

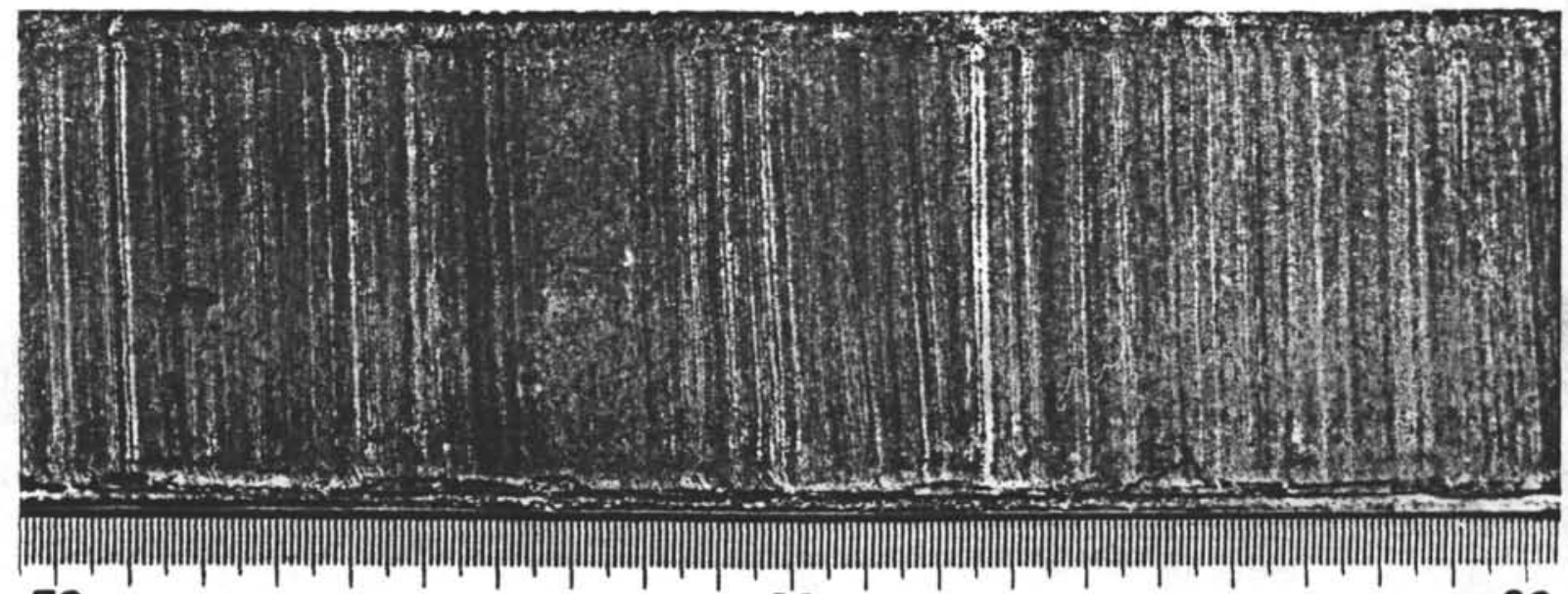

$\begin{array}{lllllllllllllllllllll}70 & 71 & 72 & 73 & 74 & 75 & 76 & 77 & 78 & 79 & 80 & 81 & 82 & 83 & 84 & 85 & 86 & 87 & 88 & 89 & 90\end{array}$

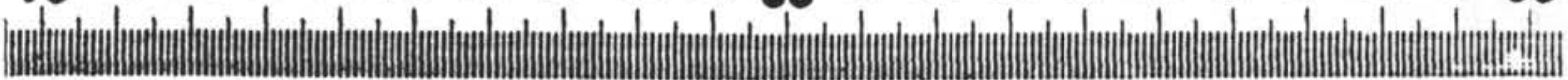

HYDRAULIC PISTON CORE

HOLE: 480 CORED INTERVAL: 95-99.5 m 
Figure 8

PREDICTION FOR $9.5 \mathrm{~m} \mathrm{H}$. P. C.

BASED ON LEG 68 PERFORMANCE

SHEAR PIN RELASE $-536 \mathrm{Kg} / \mathrm{cm}^{2}$

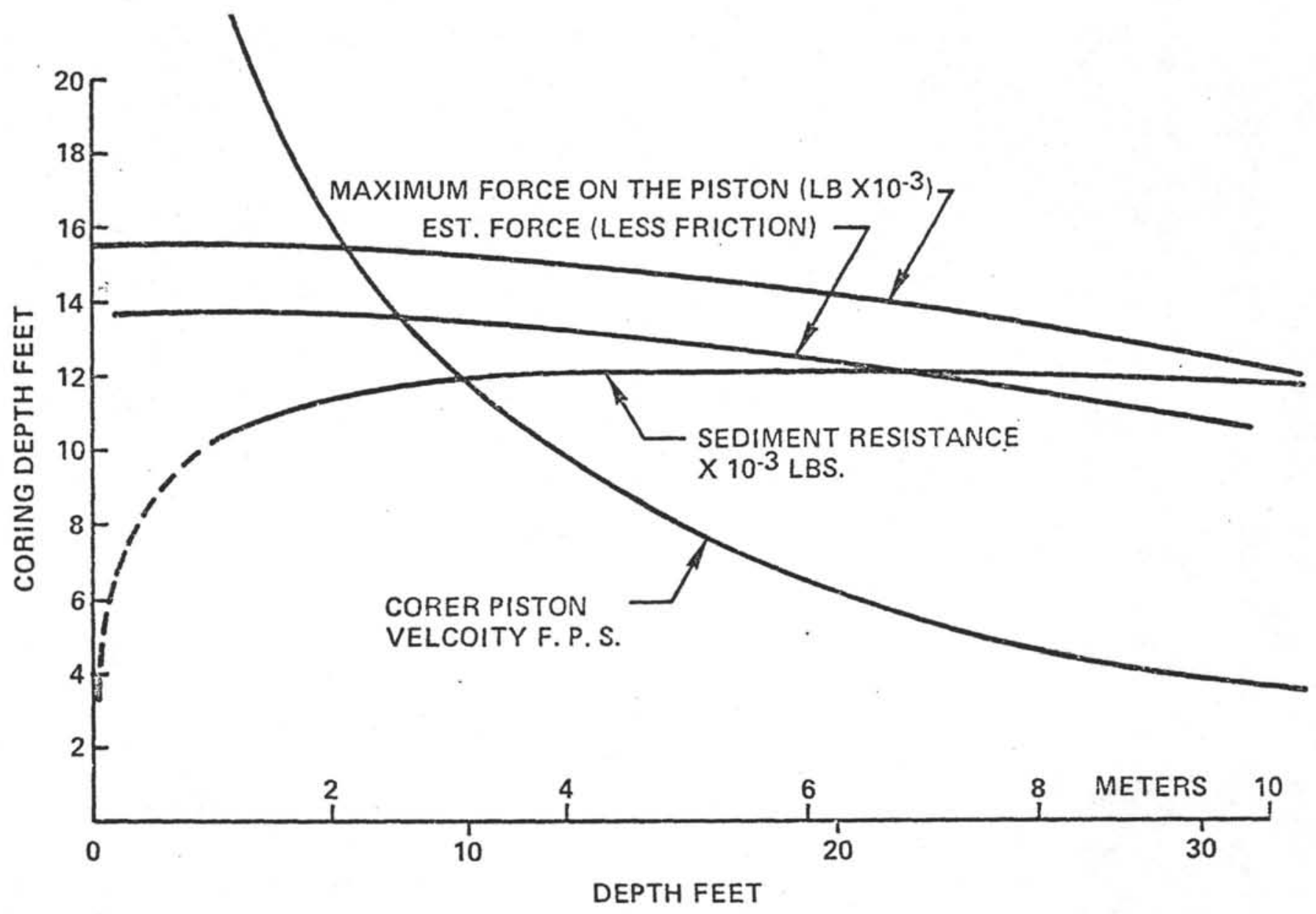


Figure 9

DEEP SEA DRILLING PRO JECT

EXTENDED CORE BARREL

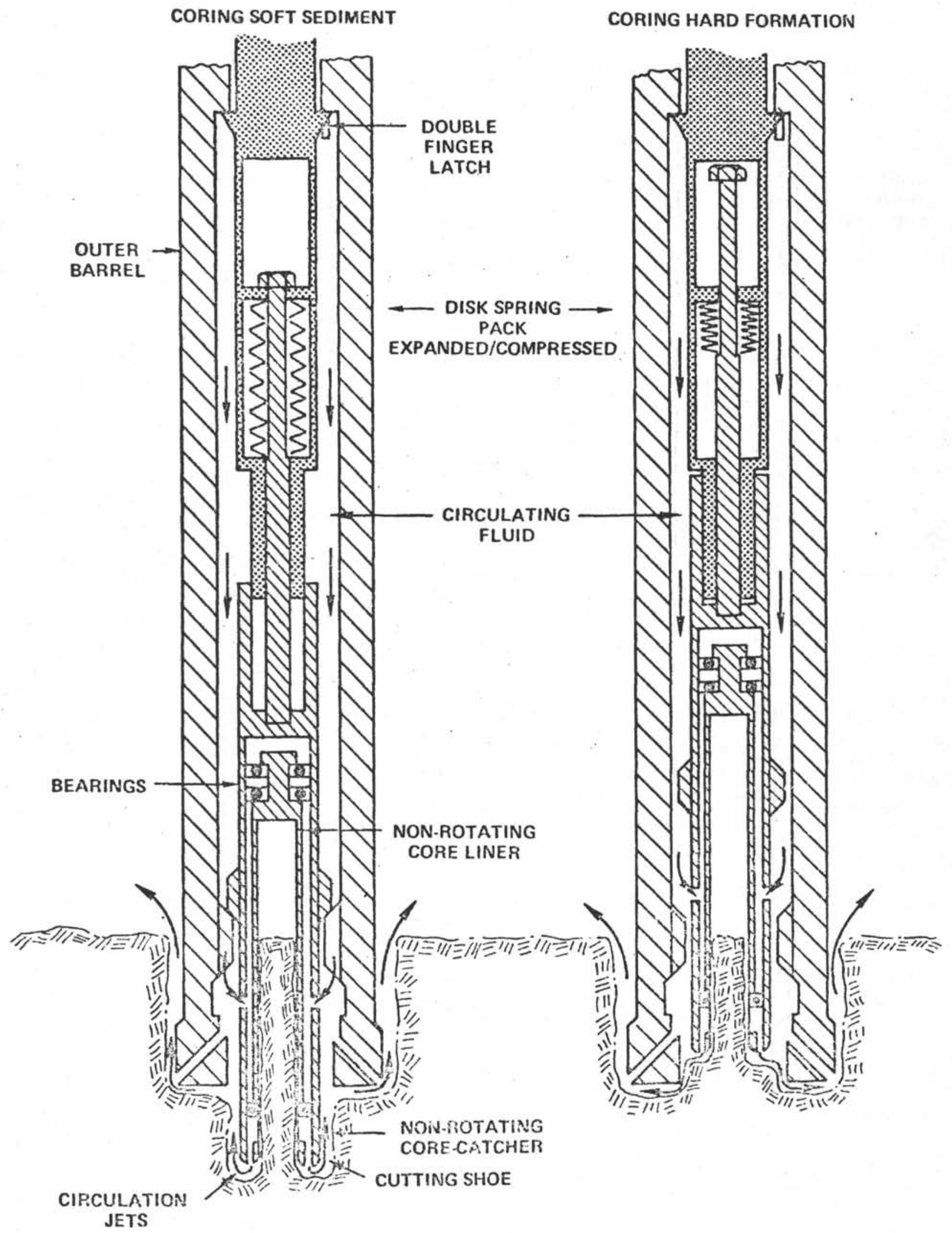


DEEP SEA DRILLING PROJECT

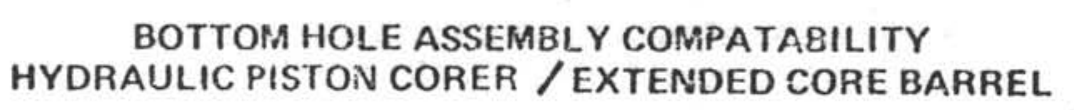

HPC
$0-200 \mathrm{~m}$

$2.44 "(6.20 \mathrm{~cm})$ CORE DIA.

$30^{\circ}(9.5 \mathrm{~m})$ CORE LENGTH

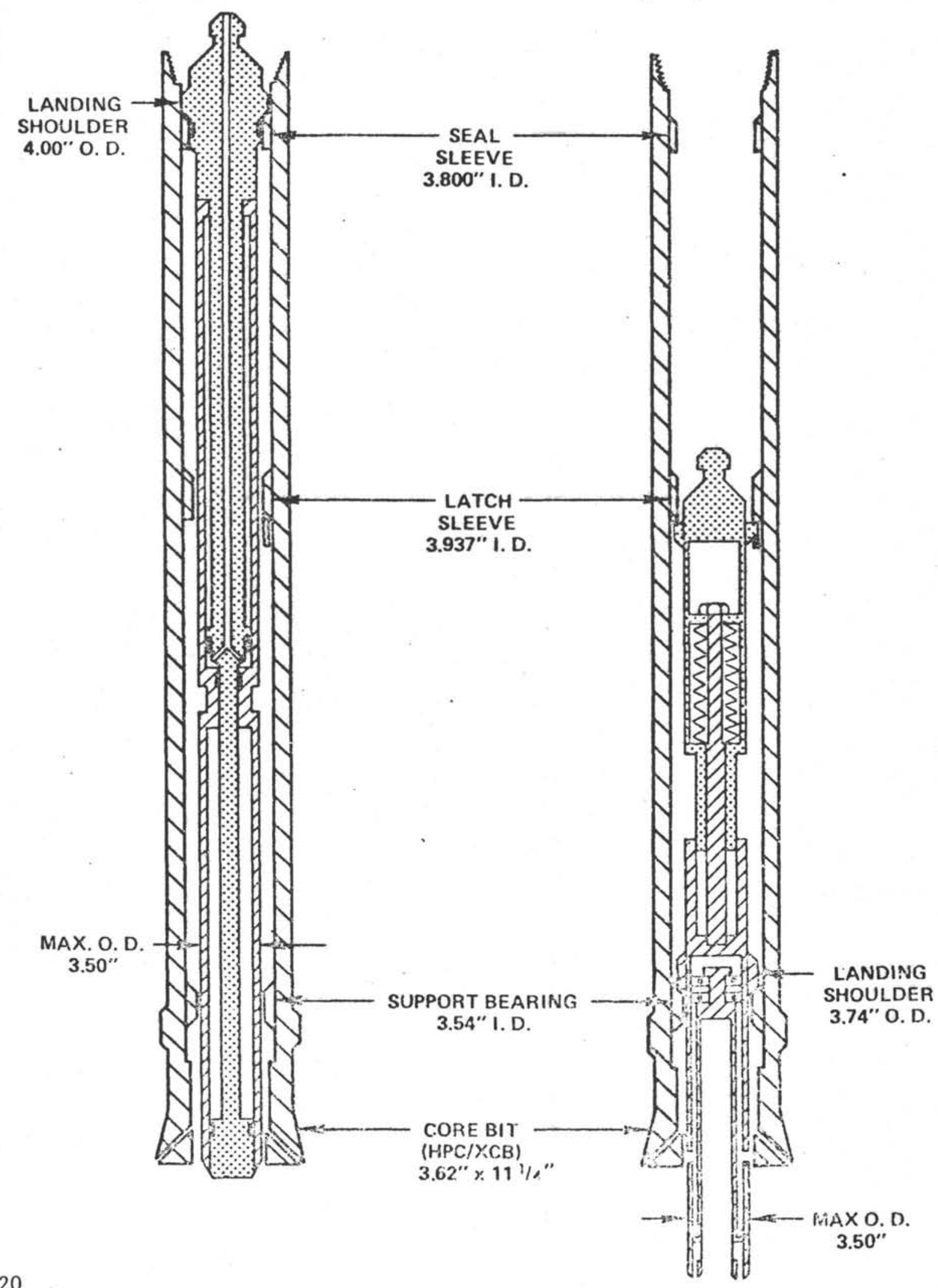




\section{TABLE I}

SPECIPICATIONS FOR CLAY PRODUCTS

DSDP PISTON CORE TEST MATERIAL

\begin{tabular}{|c|c|c|c|c|c|c|c|c|c|c|c|}
\hline $\begin{array}{l}\text { ncsn } \\
\text { 3ntch } \\
\text { No. }\end{array}$ & $\begin{array}{l}\text { J. Clay } \\
\text { Batch } \\
\text { No. }\end{array}$ & Benton1te & Feldspar & $\frac{\ln \mathrm{P}}{\mathrm{Ga} 1}$ & $\frac{\text { unds }}{\text { Clay }}$ & $\begin{array}{l}\text { Batch } \\
\text { Weight } \\
\text { 1bs }\end{array}$ & $\begin{array}{c}\text { In1tial } \\
\text { Penetrometer } \\
\text { Reading (clay only) }\end{array}$ & $\begin{array}{l}\text { Force }^{(1)} \\
\text { Extract }\end{array}$ & $\begin{array}{l}\text { P1ston } \\
\text { Pressure } \\
\text { Requ1red }\end{array}$ & $\begin{array}{l}\text { Hydraulic (3) } \\
\text { Horsepower }\end{array}$ & $\begin{array}{l}\mathrm{K} / \mathrm{SF} \\
\text { Shear } \\
\text { Strength }\end{array}$ \\
\hline 1 & $\mathrm{FB1}$ & 96 & 384 & 72 & - & 1080 & & $<400$ & $<73$ & $<11$ & -- \\
\hline 2 & FB2 & 120 & 480 & 68 & - & 1166 & & 400 & 73 & 11 & .03 \\
\hline 3 & FB3 & 144 & 576 & 63 & - & 1245 & & 1100 & 200 & 30 & .08 \\
\hline 4 & FB4 & 168 & 793 & 57 & - & 1435 & & 2200 & 400 & 60 & .16 \\
\hline $5 *$ & B4 & Clay & Soft & - & 1250 & 1200 & $4.25-4.75$ & 3000 & 545 & 82 & .22 \\
\hline $6 *$ & B3 & Clay & Soft & - & 1250 & 1200 & $4.25-7.75$ & 3000 & 545 & 82 & .22 \\
\hline $7 *$ & $B 2$ & Clay & Medium & - & 1250 & 1200 & $6.15-6.5$ & 8000 & 1455 & 218 & - \\
\hline $8 *$ & $\mathrm{BI}$ & Clay & St1ff & - & 1250 & 1200 & $9.25-9.75$ & 12000 & 2182 & 327 & .9 \\
\hline
\end{tabular}

* Indicntes J, Clay Co. product mix

(1) Excludes welght of barrel estimated at approximately

600 lbs dynamic force during coring 11kely will exceed

steady pull out force; force $1 \mathrm{~s} 15 \mathrm{ft}$ stroke.

(2) Based on force to extract

(3) Not dynamic, based on $257 \mathrm{GPM}(15 \mathrm{ft} / \mathrm{sec})$

NOTES: Annular piston cylinder volume per $15 \mathrm{ft}$ stroke $=4.3 \mathrm{gal}$ Each batch yields approximately $12 \mathrm{cu} \mathrm{ft}$. 
TABLE II

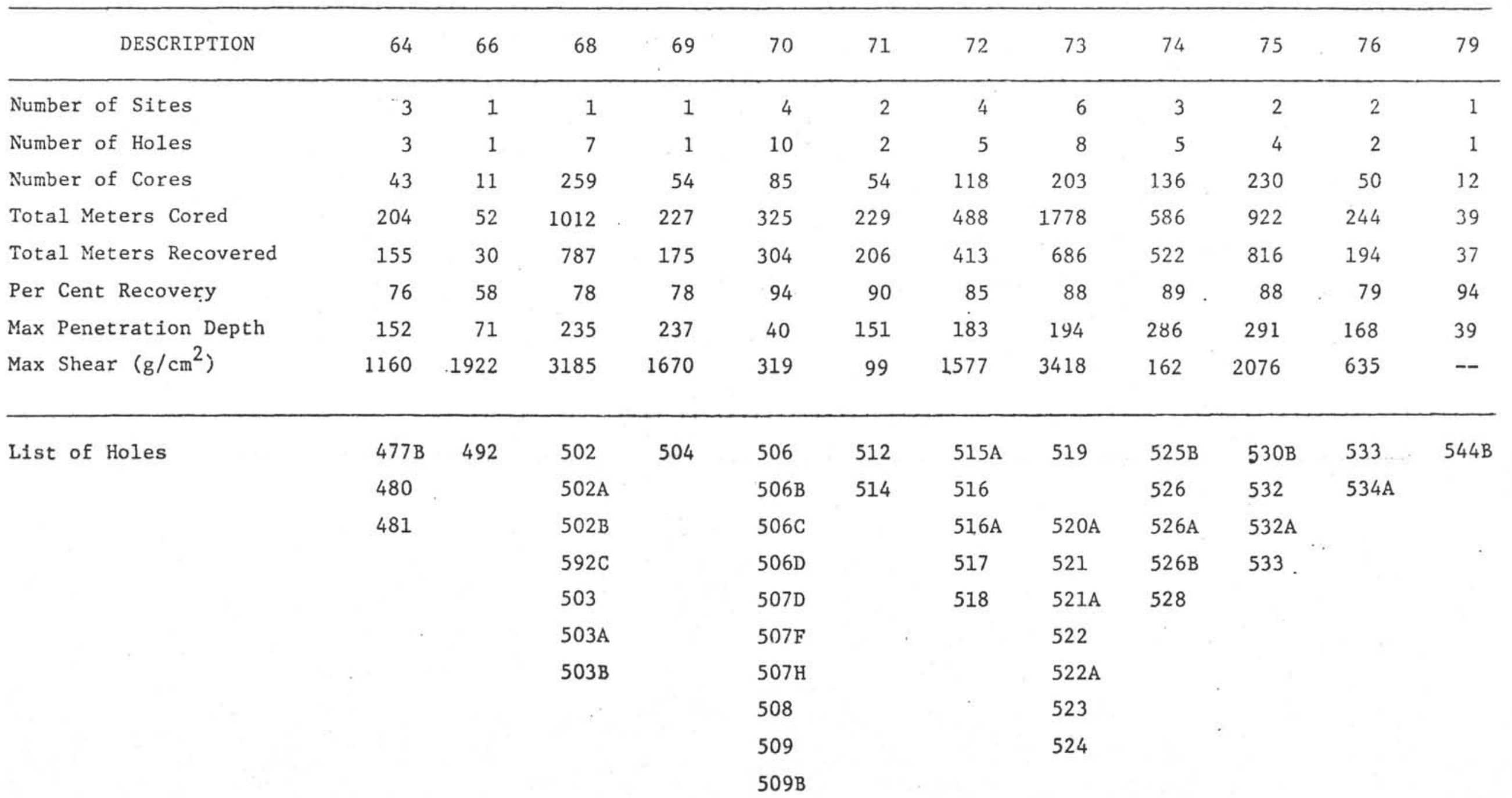

NOTE: HPC, not used on Legs $65,67,77$, , 78 , Shear not measured on Leg 79 , 
TABLE III

VARIABLE LENGTH HYDRAULIC PISTON CORE RECORD (LEG 80-93)

\begin{tabular}{|c|c|c|c|c|c|c|c|c|c|c|c|}
\hline DESCRIPTION & 80 & 81 & 82 & 85 & 86 & 87 & 89 & 90 & 91 & 92 & 93 \\
\hline Number of Sites & 2 & 2 & 1 & 4 & 5 & 1 & 1 & 7 & 1 & 6 & 1 \\
\hline Number of Holes & 2 & 2 & 1 & 13 & 10 & 3 & 3 & 12 & 3 & 11 & 1 \\
\hline Number of Cores & 77 & 42 & 16 & 183 & 11 & 49 & 61 & 358 & 7 & 49 & 11 \\
\hline Total Meters Cored & 407 & 217 & 132 & 1292 & 938 & 258 & 546 & 3,546 & 53 & 346 & 91 \\
\hline Total Meters Recovered & 355 & 216 & 124 & 1206 & 878 & 174 & 531 & 2,812 & 47 & 262 & 90 \\
\hline Per Cent Recovery & 87 & 100 & 94 & 93 & 93 & 67 & 97 & 79 & 89 & 75 & 99 \\
\hline Max Penetration Depth & 211 & 193 & 132 & 206 & 176 & 152 & 305 & 315 & 70 & 55 & 91 \\
\hline Max Shear $\left(\mathrm{g} / \mathrm{cm}^{2}\right)$ & - & - & - & 700 & -- & & -- & & & -- & -- \\
\hline $\begin{array}{l}\text { NOTE: VLHPC not used on Legs } 83 \text {, } \\
\text { Shear not measured on HPC }\end{array}$ & $\begin{array}{l}84,88 \\
\text { cores for Legs }\end{array}$ & $\begin{array}{l}80 \\
89 \text {, }\end{array}$ & $\begin{array}{l}81,82,86 \\
92,93\end{array}$ & $\begin{array}{l}571 \\
572 \\
572 A \\
572 B \\
572 C \\
573 \\
573 A \\
574 \\
574 A \\
\\
575 A \\
575 B \\
575 C\end{array}$ & $\begin{array}{l}576 \\
576 \mathrm{~A} \\
576 \mathrm{~B} \\
577 \\
577 \mathrm{~A} \\
577 \mathrm{~B} \\
578 \\
579 \\
579 \mathrm{~A} \\
580\end{array}$ & $\begin{array}{l}583 \\
583 \mathrm{~A} \\
583 \mathrm{~B} \\
583 \mathrm{C}\end{array}$ & $\begin{array}{l}586 \\
586 \mathrm{~A} \\
586 \mathrm{~B}\end{array}$ & $\begin{array}{l}587 \\
588 \\
588 \mathrm{~A} \\
588 \mathrm{~B} \\
588 \mathrm{C} \\
589 \\
590 \\
590 \mathrm{~A} \\
590 \mathrm{~B} \\
591 \\
591 \mathrm{~A} \\
591 \mathrm{~B} \\
592 \\
593 \\
593 \mathrm{~A}\end{array}$ & $\begin{array}{l}596 \\
596 \mathrm{~A} \\
596 \mathrm{~B}\end{array}$ & $\begin{array}{l}597 \\
597 \mathrm{~A} \\
598 \\
599 \\
599 \mathrm{~B} \\
600 \\
600 \mathrm{~A} \\
600 \mathrm{~B} \\
600 \mathrm{C} \\
601 \\
602 \mathrm{~A}\end{array}$ & $603 \mathrm{C}$ \\
\hline
\end{tabular}




\section{HYDRAULIC PISTON CORER (HPC-15) LEG 64}

\section{ABSTRACT}

The Hydraulic Piston Corer (HPC) was brought aboard on the evening of December 22, 1978 during a mid-cruise personnel/equipment transfer. Fourteen hours later it had its first test. It was operated a total of 51 times on three sites at depths ranging from 675 meters to 2100 meters. The tool proved fully operational, recovering a near continuous section totaling 152 meters of beautifully laminated, undisturbed cores on Site 480 .

The HPC does not need extensive redressing between runs; the turnaround time on deck is about 20 minutes (when no seals have to be changed), using and redressing the same core barrel. After the initial runs, the drill crew handled the entire operation.

The one recurring problem was the frequent destruction of top sub packing. Some modifications are suggested to facilitate operation and handling of the tool.

\section{SUMMARY OF TESTS}

Details of each run can be obtained from the notes following the report. The intent of this section is to summarize the results of the tests and the problems encountered at each site.

The Cameron relief valve was not used in the system. On the first site (477B), the blowout was not used. The Saunders line stripper packing was considered adequate to maintain pressure up to $3000 \mathrm{psi}$. The wiper packing blewout on Run No. 3 when the system overpressurized. The blowout preventer was used from then on.

Once the tool was landed in the head sub, the normal activation procedure was to:

1) Close the blowout preventer.

2) Start pumping at $40 \mathrm{SPM}$. After about 30 seconds, the pressure in the drill string would begin to rise, first slowly, then quickly as the HPC seated.

3) When the pressure reached $1500-1700 \mathrm{psi}$, a slight deflection on the gauge would signal the driller that the pins has sheared and he would shut off the pump.

4) The pressure would then drop as it escaped through the vent holes which are open at the end of the HPC stroke. 
Water Depth - $2020 \mathrm{M}$

Number of Runs - 3

Blowout Preventor - Not Used

At this water depth, the HPC was pumped down on the wireline to approximately 300 meters from the bottom, then lowered the rest of the way with the pumps off.

Run No. 1, the tool seated and activated, but the pressure did not drop afterwards. Later, it was discovered that the piston rod was 10 inches too long, thus at the end of its stroke, the vent holes were not aligned on either side of the outer seal sub and the HPC could not vent. Somewhere along the return trip, the lower core barrel section below the double pin sub backed off and was lost downhole. The threads were not damaged so it is assumed that the connection was not made tight enough.

On Run No. 2, the tool did not seat. Assuming that the lower core barrel from the initial run was still in the pipe, the HPC was retrieved and an unsuccessful fishing attempt was made. Then a regular core barrel, the same length as the HPC, was sent down. It seated so the pipe was thought to be clean.

On the third run, the HPC again did not seat. The pump rate was slowly increased to 60 SPM with gradual pressure rise. Suddenly the tool seated, shot off, and the pressure rose to $3000 \mathrm{psi}$, at which time the line wiper packing blewout.

The HPC was retrieved and found to have recovered four meters of very soft mud (using the spring leaf catcher). In the catcher was an eight-inch piece of the upper liner support from the missing core barrel. It was neatly sheared in half. When the pipe was pulled, the other half of this piece was found in the outer core barrel. It had been splayed out to the shape of the I.D. of the outer core barrel.

\section{Problems Encountered}

1) The top sub ring packing was destroyed or lost on each run. It is suspected that they are destroyed as the tool is pulled back up the pipe, and the lips of the seals snag at the pipe joints (a 1000 pound increase in weight was noted each time a joint was passed until the packing was gone). Each time the HPC was retrieved without pumping and at one half the rate of regular core barrel retrieval.

2) The sectioned piston rod, later found to be ten inches too long, was used for all three runs. After the first run, we replaced the 9-3/4" 1ower sub with a 15" lower sub to keep the piston head from jamming through the core xatchers. But, as stated earlier, this also caused misalignment of the venting holes in the rod.

3) The piston head packing had to be replaced after the second run. 
4) After the first run, great care was taken to torque tight the pin sub/ core barrel connection. Chain tongs were braced against the standing-off section of drill pipe and a $26^{\prime \prime}$ pipe wrench with cheater was used to tighten the connection.

5) After the split locking collar is removed and the cap sub connection is broken, it is still very hard to unscrew the cab sub, since the shaft above the connection cannot be kept straight enough to keep it from binding the cap sub. Therefore, the locking collar was not removed after Run No. 2 . Tension was ekpt on the top sub via the tugger while unscrewing the cap sub.

6) The $3 / 8 "$ set screw locks are too soft. They frequently jam in their hole, making it necessary to use an easy out to back them out.

Site 480

Water Depth - $765 \mathrm{M}$

Number of Runs - 32

Blowout Preventor - Used

HPC operation on this site was a total success. One hundred fifty two meters of core were drilled with over $90 \%$ recovery. The beautifully varved sedimentary sections, ranging from soft mud to very firm diatomacous ooze, were virtually undisturbed.

Prior to this site, the HPC was totally dismantled and redressed. Both the inner and outer sub seals were worn but still good. They were replaced. There were no damaged parts, but the piston rod was corroded. It was sanded, greased, and stowed away. The outer body was swabbed with solvent and greased on the inside. the HPC was reassembled with the one piece piston rod. The head sub landing surface was filed to smooth the rough edges where the metal had "rolled" slightly.

In an attempt to preserve the top sub packing, the six packing rings were oriented such that they faced each other in sets (i.e., the first ring pointing up; the second pointing down; the third pointing up; etc.). The brass ring was situated between the upper four and lower two packing rings.

To test this configuration, the HPC was run 200 meters down pipe, then retrieved. The lower three packing rings were gone. In order to remove the top connector to change the packing, the eight pins had be sheared (it is impossible to pull them out once they are set). The method used is as follows:

1) Lay down the upper section HPC and unscrew the outer body cap to pul1 the shaft about a foot out of the outer body.

2) With a sledge and a wedge, force the outer body cap away from the top sub to shear the pins.

3) Slide the outer body cap down the shaft to reveal the set screw locking the top sub to the shaft. The rest is easy. 
The packing was replaced in the original configuration and the tool run down the pipe. No pumping was needed in this shallow water.

The first two runs had excellent core recoveries, but the packing was 1ost each time. On the third run, however, all the packing returned intact. The derrickman had been continually reducing the rate of retrieval, and finally found a slow enough speed to preserve the packing (just under $100 \mathrm{~m} / \mathrm{min}$ ). The packing had to be changed, again, after Runs Nos. 12, 20, and 25.

The piston head " $\mathrm{V}$ " packing was changed after Run No. 3. They were replaced with polypaks. The polypaks did not inhibit the tool from scoping together during assembly. This packin g had to be changed, again, after Runs Nos. 12, 25, and 27. On Runs Nos. 3, 25, and 27, the core 1iner had partially collapsed and cracked. This may have caused the damage to the piston head packing.

Runs Nos. 12 and 13, had low recovery. Each of these runs was also characterized by an absence of pressure relief after tool activation. It was suspected that a sandy layer was keeping the HPC from fully extending during actuation. Some sand was recovered on Run No. 13. The driller washed down 4.75 meters in an attempt to get through the sandy section. Also, the inner and outer seals were changed, though after 13 runs, the old ones still looked OK. On the subsequent runs, the recovery increased and the tool actuated normally.

The core liner returned cracked or partially collapsed after Runs Nos. 3, $21,24,25,28$ through 32 . This may have been caused by the increasing stiffness of the sediment. The recovery was still good. The liners usually collapsed just ahove the lower liner support. The cracks were longitudinal and usually at the upper end of the liner.

\section{Site 481}

Water Depth - 2016 M

Number of Runs - 25

Blowout Preventor - Used

Prior to this site, the HPC was totally dismantled and redressed. The outer sub seals were badly damaged. The "V" packing on the inner seal sub was worn but undamaged. The piston rod was corroded. It was sanded and regreased. We had run out of shear pins, so we made more out of $3 / 16$ " brass brazing rod. They worked very well, shearing at a slightly higher pressure 1700-1900 psi).

On this site, the HPC was pumped down (as it was on Site 477B). The first two runs were water cores. The recovery was good on the next three runs. On the sixth run, the recovery dropped to 1.7 meters; the eighth and ninth runs produced zero recovery. Starting with Run No. 5, the pressure did not drop quickly after the pins sheared. The pressure would build up to 2000 psi, but no deflection registered on the pressure gauge. The driller said there was no evidence of a hard or sandy layer. Suspecting that the inner or outer seals were leaking, the HPC was overhauled. Seals were undamaged. 
Runs Nos. 9 and 10, attempted to recore lost intervals from the two previous runs. No recovery on Run No. 9, and 0.2 meters was recovered on Run No. 10. Recovery picked up to 4.57 meters with Run No. 11. On Run No. 12, the HPC came back with pins unsheared. Runs 13 through 16 had good recovery.

The blowout preventer, which had been in use since the beginning of Site 480 , was by this time leaking badly (there was no spare packing). This may have had an effect on the driving force behind the HPC as it sheared, thus inhibiting complete extention and proper venting.

The top sub packing had to be changed after Runs Nos. 4 and 14 .

\section{CONCLUSIONS}

The HPC was an operational and scientific success.

Advantages

1) Good recovery of undisturbed sediments.

2) Relatively fast turnaround time on deck.

3) No major tool damage or breakdowns after extensive use.

4) Entire operation can be handled by rig crew.

\section{Disadvantages}

1) The necessity of using a special large diameter drill bit and head sub for HPC coring requires tripping the pipe to change the bottom hole assembly when piston cores are desired.

2) Top sub ring packing lasts from two to ten runs before becoming lost or damaged. The HPC is retrieved at a very slow speed in order to save the packing. In deep water holes this will be time consuming.

3) When making up the double pin sub/cab sub connection (the lower core barrel section is hung off in the pipe, and the upper HPC section is on the tugger line), a rig hand has to ride up on the harness to hold the shaft straight to keep from binding the threads. This is dangerous when the ship is rolling. If the shaft swings out of his grasp, it can swing back and smash him against the drill pipe.

\section{Suggestions}

1. Changing shear pins was the most time consuming phase of the turnaround routine. The pins should be made stronger to reduce the number needed. Also, threaded shear pins should be considered. They would eliminate the necessity of lining up the outer body cap with the shear groove to punch out the used stubs. Eliminating the set screw backers would mean less small parts to keep track of during turnaround operation. 
2) Several ratchet drive allen keys and a set of easy outs should be purchased. Also need spares for all of the special assembly tools (i.e., handling clamp, special spanner wrench for outer seal sub).

3) Need a reciprocating seal for the top sub.

4) Several spare upper liner supports should be on hand. These damage easily with rough handling on rig floor.

5) Consider machining pin thread at one end of outer body. This would facilitate installation of inner seal sub without damaging seals. An additional double box sub could be used to make the connection.

6) Use the "V" packing only on the inner seal sub. The piston head works fine with polypak packing. Polypaks were tried on the inner seal sub when the "V" packing spares were depleted, but the increased friction makes it very hard to scope the tool together during assembly.

7) Fabricate a special support plate to hang shaft in pipe so the top sub can be removed to change packing without having to lay down the upper section of the HPC. The existing shear pin groove could be used to hang the shaft, or a new groove could be cut about one foor from the top of the shaft.

8) A method should be devised to keep shaft from binding when the double pin sub/cab sub connection is made up or broken when the HPC is hung off in the pipe.

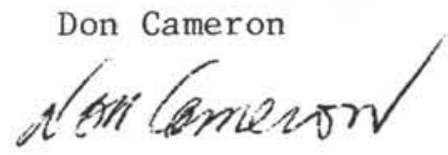


APPENDICES 
HYDRAULIC PISTON CORER.

ANALYSIS

CONTENTS

Problem Statement

Work Done

Discussion

Conclusion

Topics

Giant Piston Corer Comparison

Sediment Resistance to Coring

Shore Test Results of H.P.C. penetrating sediment.

H.P.C. coring velocity and resistance to penetration

prediction and comparison with operational results.

Development of empirical approaches for H.P.C. performance in varying sediment shear strength and compaction.

Prepared by. Wil Nugent 
SUsJECT Hydraulic Corer

SECTION:

ENGIHEER: W. Nugent

CHECXER:
H. NUGEHT

3736 GAYLE STREET

SAN DiEgo, CA 92115
MODEL.

PAGE:

REPORT:

DATE: L.aY 26 . 1978

1.0 Problem Statement

Durine Deep Sea Drilling operations there is a need to take undisturbed core samples from the drilling site. The design of the corins tool $30 \mathrm{f}$ 't. long compatible with the drill string, is to be hydraulically actuated by sea water pumped at a pressure of $2500 \mathrm{psi}$ and with a flow rate of $350 \mathrm{gmm}$; thus pressurizing the drill string and acting on the corer tool piston. Firure 1 . presents the details.

1.1 objectives.

The objectives of the analyses is to:

(a) Fredict the velocities, column loads and criteria for the corer tool when penetrating the sub-surface to depths of $100 \mathrm{~m}$.

(b) Determine the structural adequacy of the corer tool.

(c) Fredict the end of stroke snubbing and recommend devices

(d) Develop shear pin positioning / latching devices.

(e) Predict the load to be reacted by the tension rod.

2.0 Work Done.

1) A review of the Giant Piston Corer (GPC) test conducted by the University of Hawaii.

2) Review of the sub-surface foundation material densities and shear strength. Reference DSDP Technical Report No 9 September 19 ?6

3) Predict friction coefficients for sub-surface materials entrained into the the corer tool at various velocities consistent with the surface pump capacity.

4) Develop mechanization schemes in support of the corer tool desigr

5) Prepare hydraulic analysis to determine orifice sizes, diametral clearances to ensure an out flow compatible with the pump inflow

6) Analyze and recommend snubbing devices.

7) Conduct structural analysis of critical components.

3.0 Discussion

The GFC tests (University of Hawaii letter) provided velocity, acceleration, and depth of penetration data. With knowledge of the mass of each GPC test, the force developed during corer penetration was calculated. Data from Flates 15 and 19 of DSDF Technical Report no 9 provided soil shear strength, and density values at comparable depths of penetration. An estimate of the sub-surface material viscosity was made, and friction coefficients were developed using the Reynolds Number of a plate simulating the circumference of the pipe. This approach yielded loads and velocities for the hydraulic coring tool which show favourable comparison with the GPC tests.

The resistance ( $\mathrm{dra}$ ) ) of the material passine throu h the pine was calculated by the expression $R=1 / 2 \Gamma V^{2} f$ ner foot penetration. The resistance in terms of $v^{2}$ was used in the equation $V=\frac{C_{d} a}{A 3 r^{2}}\left(\frac{29}{\sigma}\right)^{1 / 2}[F-(\mu F+R)]_{\text {to }}^{1 / 2}$

as a function of the orifice characteristics.

The procedure rields velocities with reasonable accuracy. 
SUBJECT

SECTION:

ENGINEER

CHECKER:

\section{H. NUEERT \\ 3736 Gayle StreEt \\ SAN DiEgo, CA 92115}

MODEL

PAGE.

REPORT

DATE:

The loads predicted for the hydraulic corer appear to be 12 per cent

higher than anticipated when compared to the GPC data.

4.0 Conclusions.

1) Coring operations 0 to 50 feet below the surface are predicted as follows:

$\begin{array}{ccccc}\begin{array}{c}\text { Depth of } \\ \text { enetration } \\ \text { Ft. }\end{array} & \begin{array}{c}\text { Column } \\ \text { Stress } \\ \text { psi }\end{array} & \begin{array}{c}\text { 30 Ft.Column } \\ \text { Buckling Stress } \\ \text { psi }\end{array} & \begin{array}{c}\text { Deflection } \\ 30 \text { t. Column } \\ \text { ins }\end{array} & \begin{array}{c}\text { Safety } \\ \text { liargin }\end{array} \\ 15 & 1353 & 2831 & 1.67 & 2.08 \\ 20 & 1739 & 2831 & 2.17 & 1.63 \\ 25 & 2077 & 2831 & 2.55 & 1.36 \\ 30 & 2406 & 2831 & 3.00 & 1.17 \\ * 30 \text { at } 100 \mathrm{~m} . & 2602 & 2831 & 3.25 & 1.08\end{array}$

Taking cores greater than $25 \mathrm{ft}$. in length with the 3.5 inch diameter barrel is not recommended prior to full scale test.Figure 2 presents a plot of the column stress, corer end load, and penetration velocity versus penetration depth.

2) Coring at $100 \mathrm{~m}$. is accomplished by limiting the surface pump pressure to 1000 psi and $200 \mathrm{gpm}$.

3) Orifice Characteristics. 2- 0.5 inch diameter orifices below the corer piston, Refer to Figure 1. provide fluid flow out from the core chamber at $410 \mathrm{gpm}$. This added flow compensates for the release of additional fluid stored during pressurization of the drill string. A diametral clearance not less than .023 inches is required to disharje the fluid from the top side of the corer barrel. Refer to Figure 1.

4) Snubbing is provided by a double stack of Bellville washers .19 thickness ( a total of 20) to dissipate $2255 \mathrm{ft} 1 \mathrm{bs}$ which results in

$40,0001 \mathrm{~b} /$ inch? to be reacted by the tension rod.

5) Shear Pin(s) are provided to retain the corer barrel in the lockshut position during deployment, and to be released under $2000 \mathrm{psi}$ pump pressure

A $\cap .37$ inch diameter single pin is required.

Two pis having 0.213 inch diamer are required as alternatives to one pin. The material 4130 steel HT F tu 125,000 psi with a yield value 109,000 psi is required. 
HYDRALLIC PISTON CORGR TOOL FIGURG 1

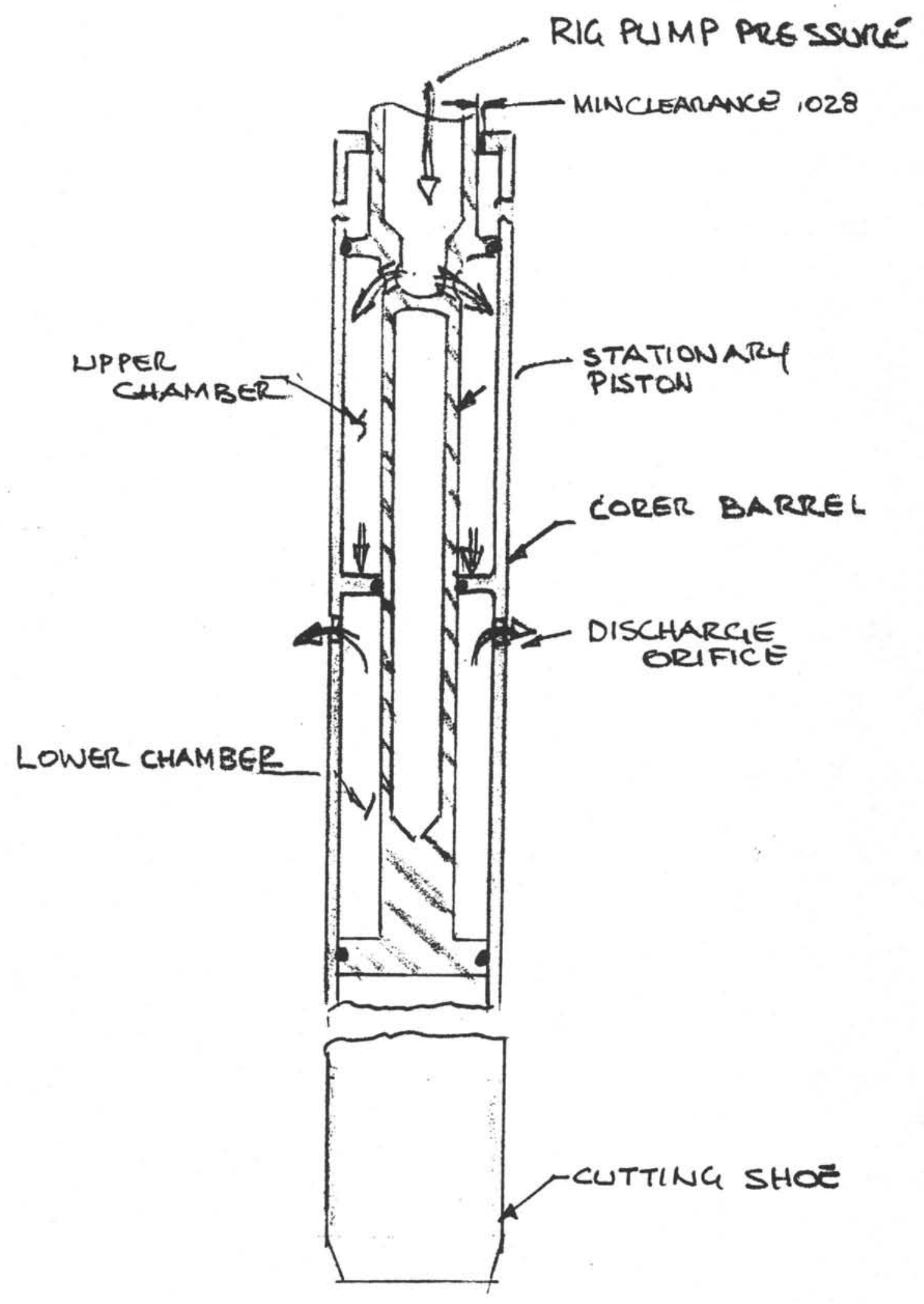

36 


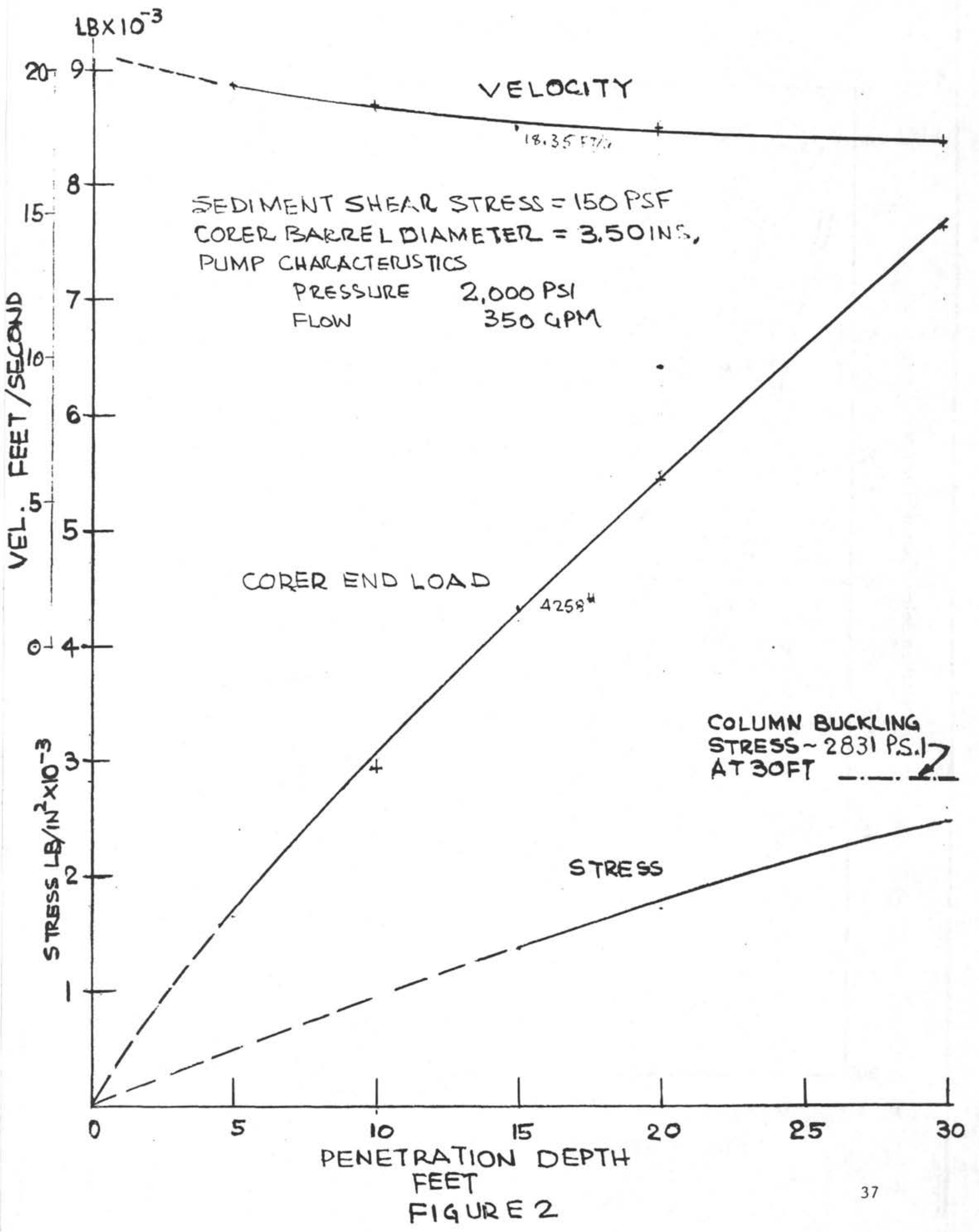


Shear Strength, ksf

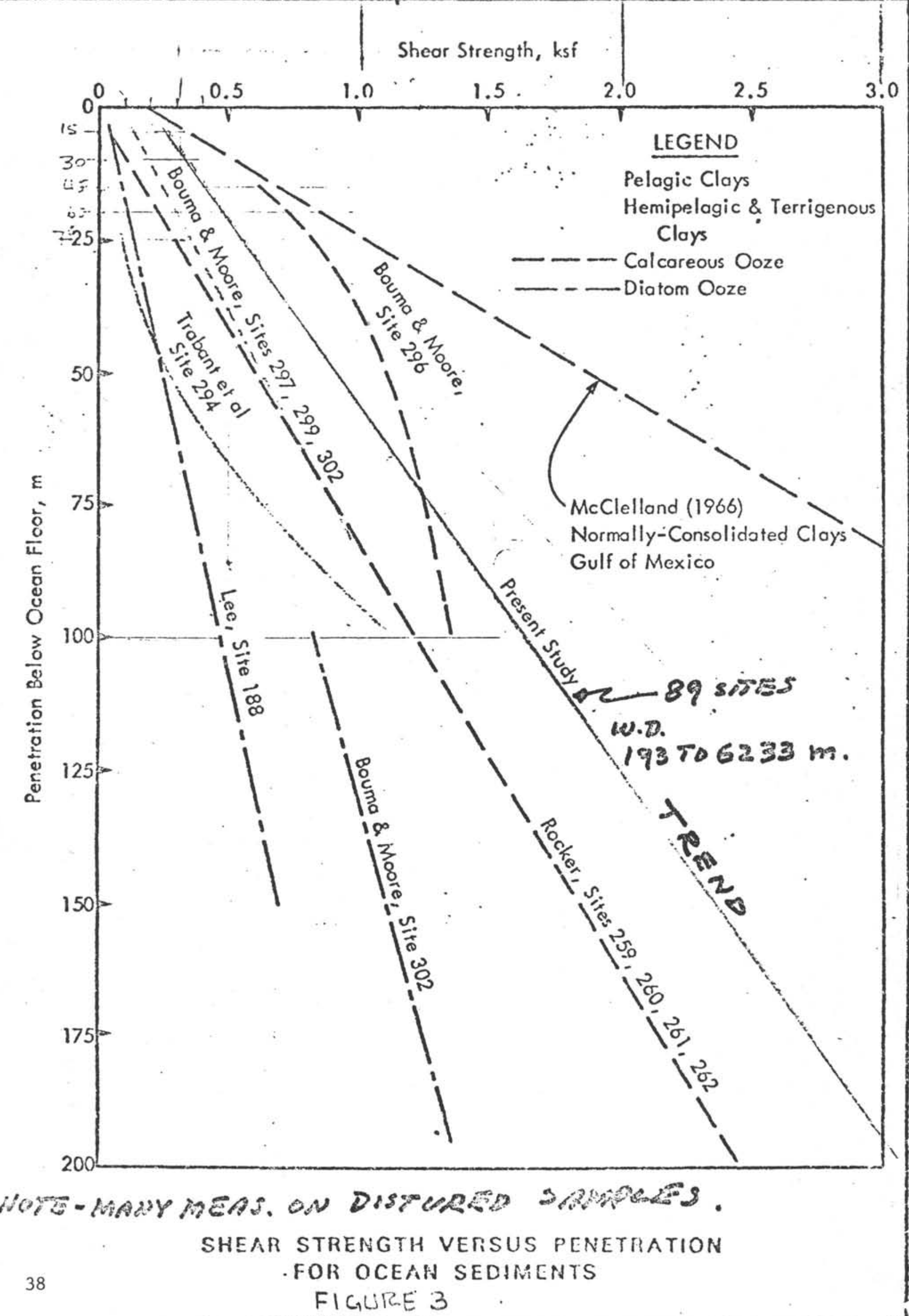


MAY 261978.

COMPARISON OF G,P.C TEST No 4 UNIU. HAWAII

WITH UNIV CAUFORNIA STRIPS INST. HYDRAULIC PISTON CORER PROPOSED CONFIGURATION

HYDRAULIC PISTON CORER CASE I

\begin{tabular}{|l|l|c|c|}
\hline & DIMENSIONS & AREA IN 2 & AREA FT 2 \\
\hline $\begin{array}{c}\text { CORER PISTON } \\
\text { ANNULUS }\end{array}$ & $(2,88$ ID $=1,12$ ROD $)$ & 5,5 & .0382 \\
\hline DRILL MOLAR & 4,125 & 13,364 &, 0928 \\
\hline
\end{tabular}

VOLUME OF DRILl STRING $18000(.0928) \quad 1670.5 \mathrm{FT}^{3}$

COMPRESSION OF FRESH WATER.0065VOL@2000PSI THEN $\frac{\Delta V}{V}=10065$

COMPRESSED VOLUME IN $18000 \mathrm{FT}$ STRING $=10.86 \mathrm{FT}^{3}$

INCREMENTAL CORER PISTON LORD $(10.86 \times 64.3)=698.3$

INCREASED PISTON PRESSURE $6983 / 5.5=126 \mathrm{PSI}$

EQUIVALENT WATER COLUMN IN DRILL PIPE = 117 FE

DATA FROM G.P.C. TEST NO 4

\begin{tabular}{|l|l|l|c|c}
\hline DISPL,DEPTH & ACCEL $(y)$ & $\begin{array}{c}\text { VELOCITY } \\
\text { F.P.S }\end{array}$ & $\begin{array}{c}\text { SHEAR STR } \\
\text { MECLELLAND DATA }\end{array}$ & $\mu=T\left(\frac{d x}{d v}\right)$ \\
\hline 10 & 0.6 & 18 & 50 & \\
20 & 0.8 & 20 & 75 & \\
30 & 1.1 & 22 & 114 & 9.45 \\
40 & 1.4 & 18 & 152 & \\
50 & 1.6 & 16 & 190 & \\
\hline
\end{tabular}

FRICTION ESTIMATE

$$
f=1.328 \sqrt{\frac{\mu}{\rho V X}}=1.328 \sqrt{\frac{9.45}{3.85(18)(1.12}}=.463
$$

A VALUE OF 18 FEET PER SECOND HAS BEEN USED IN

39 THE ESTIMATE FOR THE AVERAGE PENETRATION VELOCITY. 
DYNAMIC PRESSURE (SEDIMENT RESISTANCE TO CORING)

$$
\begin{aligned}
D & =1 / 2 \rho V^{2} f \text { PSF. } \\
& =1.925(.463) V^{2}=.892 V^{2} \text { PSF }
\end{aligned}
$$

SINCE TI DIAM) OF THE PIPE $\approx 12 \mathrm{IN}$

$D=1892 V^{2}$ (PSF) I RESISTANCE PER FOOT LENGTH OF PENETRATION

THE FOLLOWING EXPRESSION IS USED TO RELATE THE PENETRATION VELOCITY AND THE RESISTANCE OF THE SEDIMENT TO CORING,

$$
\begin{aligned}
V & =\frac{C_{d}^{a}}{A}\left(\frac{2 g}{\sigma}\right)^{1 / 2}[R I G \text { PRESSURE - DYNAMIC IMPACT PRESSURE }]^{\frac{1}{2}} \\
& =\frac{C_{d} a}{A}\left(\frac{2 g}{\sigma}\right)^{1 / 2}\left\{\left[\frac{F-\mu F}{A}\right]^{1 / 2}-[D(P S F)]^{1 / 2}\right\}
\end{aligned}
$$

WHERE:

$$
\begin{aligned}
& V=\text { PISTON VELOCITY FPS (TaD) } \\
& A=\text { PISTON ANNULUS AREA }=5,51 \mathrm{~N}^{2}=\left(0,0382 \mathrm{FT}^{2}\right) \\
& \sigma=\text { SEA WATER DENSITY }=64,3 \mathrm{LB} / \mathrm{FT}^{3} \\
& P=\text { HYDRAuLIC PRESSuRE }=2,000 \text { PSI }(288,000 \text { PST) } \\
& F=\text { FORcE ON PISTON }=11,000(.8)=8800 \mathrm{LB} \\
& \mu=\text { COEFFICIENT OF SLIDING FRICTION }=0.2 \\
& \sigma=\text { SEDIMENT MASS DENSITY }=3.85 \text { SLUGS/FT }{ }^{2} \\
& a=\text { ORIFICE AREA }=2 \cdot 1 / 21 \mathrm{NDIA}=0.00273 \mathrm{FT}^{2} \\
& C_{d}=\text { ORIFICE DISCHARGE COEFFICIENT }=0.62 \\
& Q=\text { VOLUMETRIC DISCHARGE }=.62(.00773) \sqrt{2126(144)}=0.9365 \mathrm{FT}^{3} \\
& =448.83(0.9365)=420 \mathrm{gPm} \text {. }
\end{aligned}
$$

$D=$ RESISTANCE OF THE EMINENT (ASSUMED TO BE CONSTANT FOR LIQUIIIIL SEDIMENTS IN THE FIRST ORDER ANALYSIS.)

THEN FOR 5 FEET, PENETRATION

$$
\begin{aligned}
V & =.04426\left\{[230,400]^{1 / 2}\left[5(.892) V^{2}\right]^{1 / 2}\right\} \\
& =\quad 21.24-.0935 \mathrm{~V} \\
& =
\end{aligned}
$$


THE COLUMN LOAD ON THE CORER $=5(1892) \mathrm{V}^{2}$

$$
=1682 \mathrm{LB} \text {. }
$$

CORING TO 40 FEET PENETRATION

$$
\begin{aligned}
V & =.04426[230,400]^{1 / 2}-\left[40(.892) r^{2}\right]^{1 / 2} \\
& =16.8 \mathrm{FT} / \mathrm{sEC}
\end{aligned}
$$

THE COLUMN LOAD ONTHE CORER $=10,006 . \mathrm{LB}$.

FIGURE 4 shoWs a PLOT of the data Generated BY THE FIRST TRIAL ANALYSIS.

THese data were compared with the results of THE GIANT PISTON CORER TESTS NOS 4 AND 5

* allow added mass as the core is taken

G.P.C DATA

\begin{tabular}{|l|l|l|l|l|}
\hline VELOCITY (F.P.S) & 20 & 22 & 18 & 16 \\
\hline PENETRATION(FT) & 10 & 20 & 30 & 40 \\
\hline ACCELERATION(G) & 8 & 1,1 & 1.4 & 1.6 \\
\hline TOTAL MASS SLUGS) 141 & 146 & 152 & $157 *$ \\
\hline RESISTANT (LBS) & 3632 & 5171 & 6852 & 8095 \\
\hline H.P.C. (CASE) & 2990 & 5450 & 7640 & 10006 \\
\hline
\end{tabular}

THE RESULTS OF THE H.P.C. FIRST ORDER ANALYSIS compare favorably WITH the results OF the GIANT PISTON CORER RECORED.TEST CONDITIONS,

FIGURE 5 SHOWS THE RESULT OF A TYPICAL SHORE TEST, WHEN THE H,P,C IN THE OPERATIONAL CONFIGURATION WAS "SHOT" INTO A STIFF $C \therefore$ MIX $20.9 \mathrm{~K} / \mathrm{SF}$.

41 
FIGURE 4

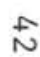

HYDRAULIC PISTON CORER CASE I

SEDIMENT SHEAR STRENGTH = 152 P.S.F

CORER BARREL DIAMETER = 2,88 INCHES 1,0 ,

ORIFICES $2-0,5$ INCHES DIAMETER

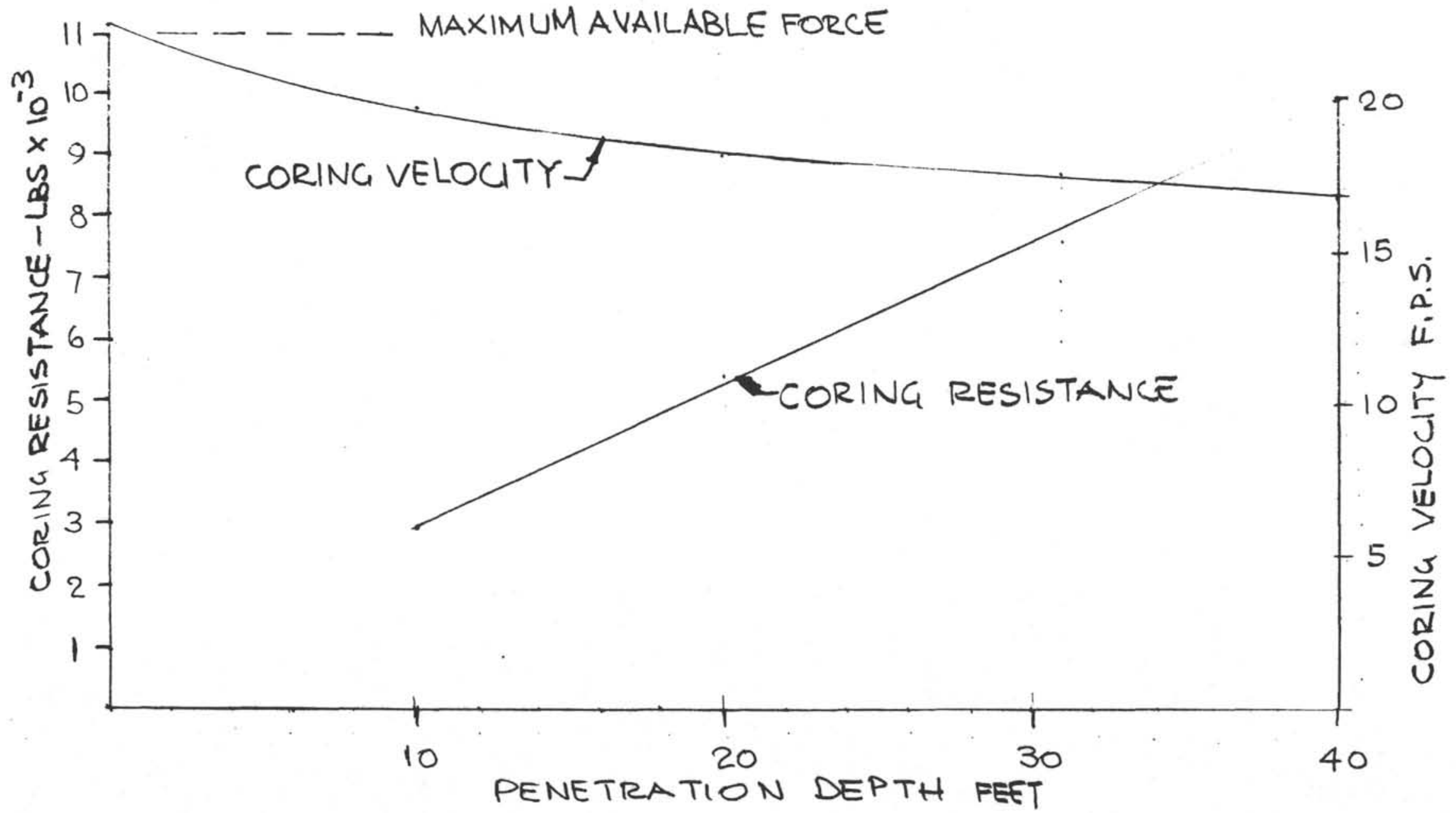


D. S. D. P. HYDRAULIC PISTON CORER TEST

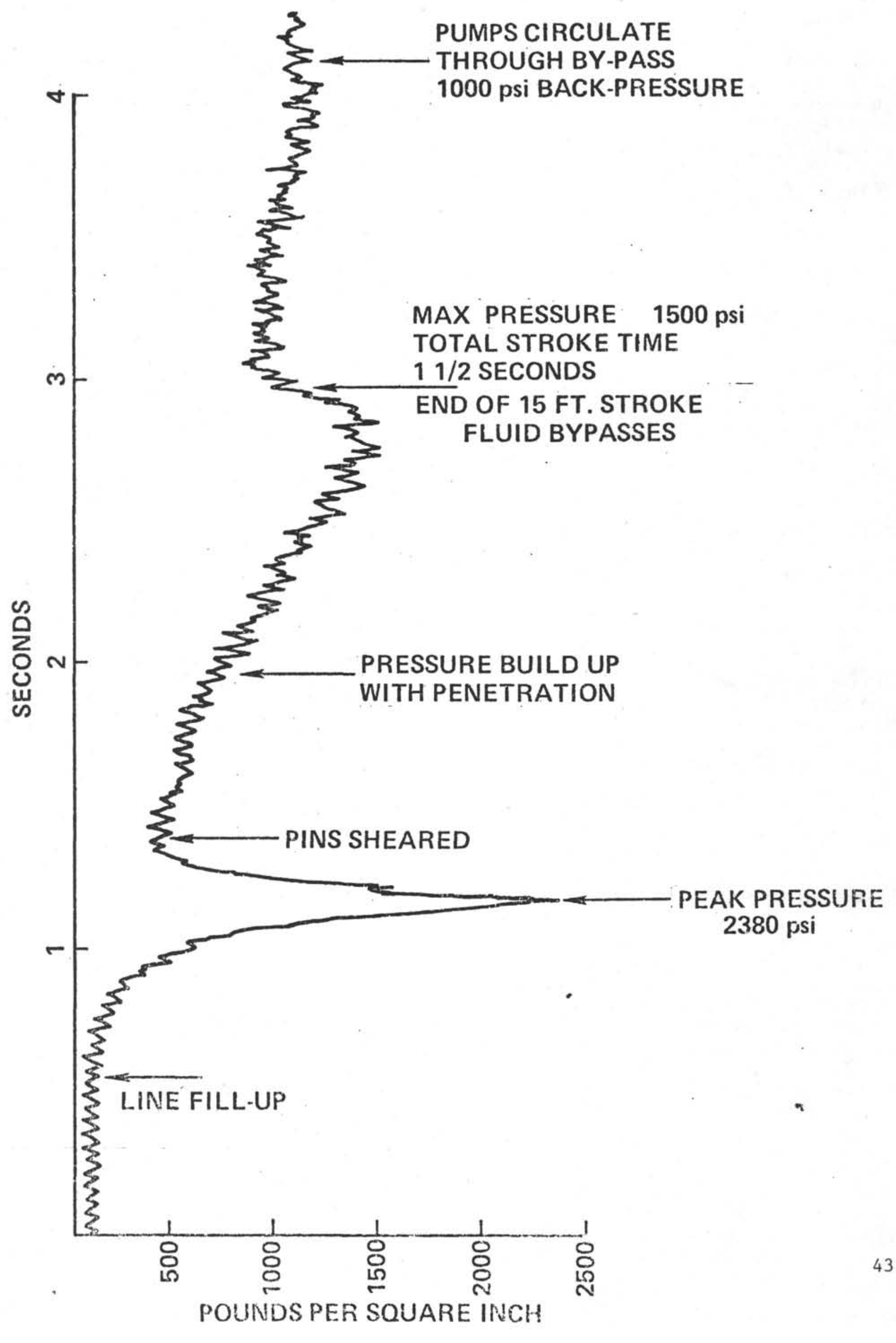




\section{HYDRAULIC PISTON CORER ANALYSIS}

Alternative methods for determining the forces and velocities developed during coring were investigated. One suggestion recommended the use of a friction factor in a Darcy Equation of .08 which was extrapolated from test data obtained from evaluating the characteristic of slurry pumped through a continuous loop.

The approach was as follows:

$$
\begin{aligned}
\text { Head loss } & =\text { Entrance loss }+ \text { Friction loss } \\
\mathrm{h} & =[0.5+\mathrm{f} .(\mathrm{l} / \mathrm{d})] \mathrm{V}^{2} / 2 \mathrm{~g}
\end{aligned}
$$

Nomenclature:

$$
\begin{aligned}
& \mathrm{h}=\text { Head loss in feet } \\
& \mathrm{f}=\text { Friction factor } \\
& \mathrm{l}=\text { Length of pipe in feet } \\
& \mathrm{d}=\text { Diameter of pipe in feet } \\
& \mathrm{V}=\text { Velocity of flow (rate of penetration) in feet } \\
& \mathrm{Q}=\text { Flow rate of circulating fluid in gpm. } \\
& \mathrm{g}=\text { Gravitation acceleration in feet/ second }
\end{aligned}
$$

The flow was assumed to be laminar

The density of the sediment was taken to be $118 \mathrm{lbs} / \mathrm{ft}^{3}$

$$
h=[0.5+0.08(30 / 0.24)] \mathrm{v}^{2} / 64.4
$$

From previous shore testing the control of the penetration velocity within the limits of $20 \mathrm{ft} /$ second was achieved. Using this value in the above equation, yields a head loss of 65.22 feet. Expressing pressure as a function of head loss and density, a value of $7696 \mathrm{lbs} / \mathrm{ft}^{2}$ is obtained.

Let 7696 lbs/Ft $2^{2}$ be the corer barrel internal pressure

The friction force on the inner wall $=(.753)(30)(7696)=173,777$ Lbs which appears unrealistic, in relation to the test results. This approach was was abandonded in favor of expression

$$
\mathrm{V}=\frac{\mathrm{Cda}_{\mathrm{da}}}{\mathrm{A}^{3} / 2}\left(\frac{2 \mathrm{~g}}{\mathrm{p}}\right)^{1 / 2}[\text { Force }- \text { Drag }]^{1 / 2}
$$

0 perational data from leg 68 indicated that full cores were not retrieved repeatedly in sediment with shear stress in excess of $3000 \mathrm{~g} / \mathrm{cm}^{2}$. Figure 5 shows the predicted plot of a data sample. CaseI is the mean of ten trials where partial cores were retrieved. Case II represents a condition where $95 \%$ of a full core was retrieved. The curves are defined by the law

$$
y=a+b x^{n}
$$


HYYDRAULIC PISTON CORING

ESTIMATE OF CORING RESISTANCE FROM OPERATIONS REPORT. LEG No 68

CASE I

MEAN VALUE OF DATA FROM CORES No 37 THROUGH No 47

Mean Sediment Shear Strength

$2,666.28 \mathrm{~g} / \mathrm{cm}^{2}$

Mean Corer Release Pressure

2,103 p.s.i.

Nean Length of Core Recovered

2.3114 meters

CASEII

DATA FRON CORE 29

Sediment Shear Strength

$1,170 \quad \mathrm{~g} / \mathrm{cm}^{2}$

Corer Release Pressure

1,650 p.s.i.

Length of Core Recovered

4.43 meters

FIGURE 5

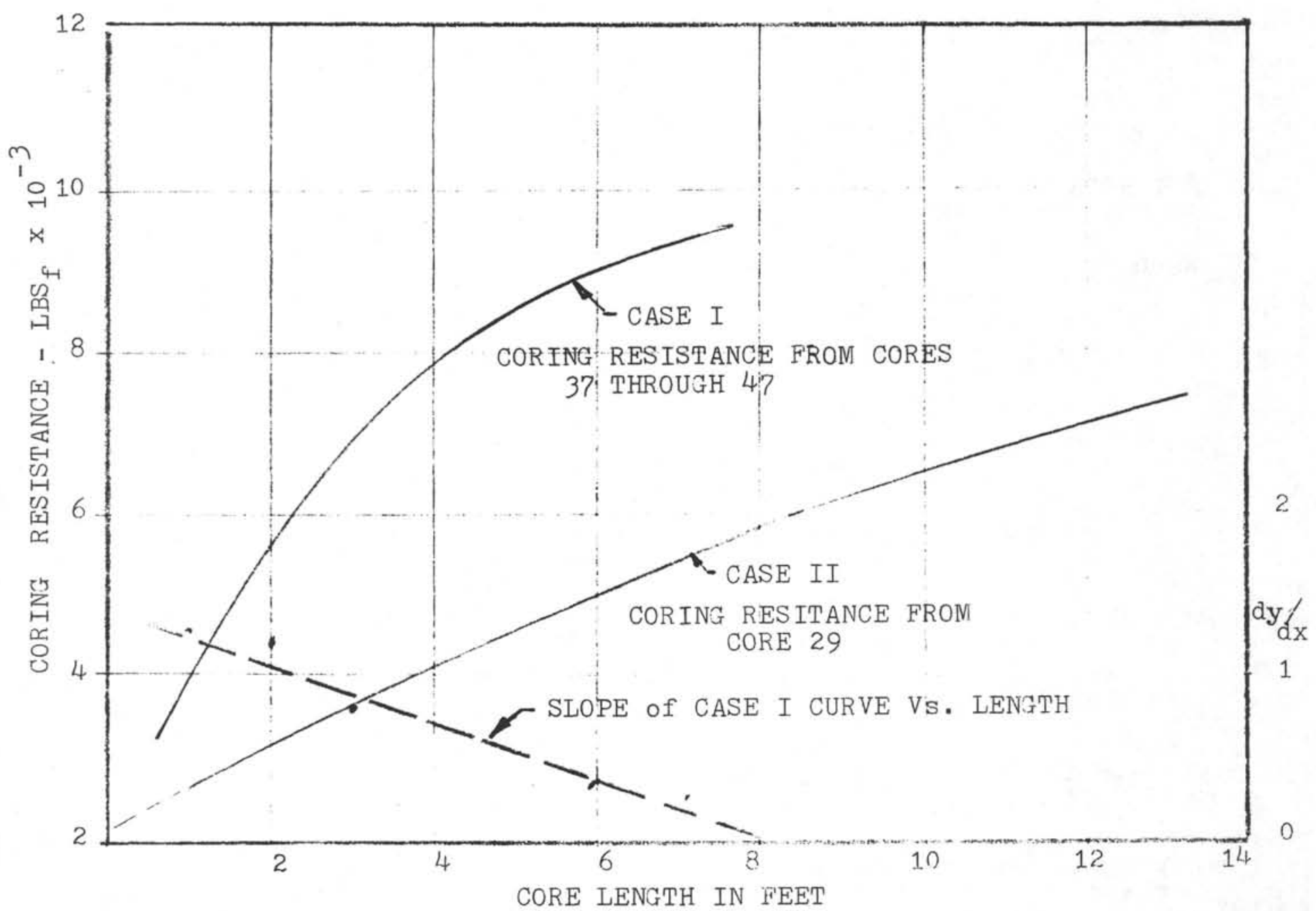


Derivation of Coring Depth Exponent

Refer to Case I

$$
\text { When } \begin{array}{lll}
\mathrm{x}=2, & \mathrm{y}=5600 & \mathrm{a}+\mathrm{b} 2^{\mathrm{n}}=5600 \\
\mathrm{x}=4 & \mathrm{y}=7800 & \mathrm{a}+\mathrm{b} 4^{\mathrm{n}}=7800 \\
\mathrm{x}=8 & \mathrm{y}=9600 & \mathrm{a}+\mathrm{b} 8^{\mathrm{n}}:=9600
\end{array}
$$

Subtract (1) from(2)

b $2^{n}\left(2^{n}-1\right)=2200$

(2) from (3)

b $2^{\mathrm{n}} 2^{\mathrm{n}}\left(2^{\mathrm{n}}-1\right)=1800$

$$
\begin{aligned}
2^{\mathrm{n}} & =\frac{1800}{2200}=.81818 \\
\mathrm{n} & =-.2895 \\
\mathrm{~b} & =\frac{2200}{\left.2^{\mathrm{n}\left(2^{\mathrm{n}}\right.}-1\right)}=-14788 \\
\mathrm{a} & =5600-\left(-14788 \times 2^{-.2895}\right)
\end{aligned}
$$

$$
y=17700-14788 x^{-.2895}
$$

Applying these principles to the ratio of $\mathrm{x}_{1}, \mathrm{x}_{2}, \mathrm{x}_{3}$, to $\mathrm{L}$ the length of core retrieved.

when $\mathrm{x}$

$$
\left(-\frac{I}{L-x}\right)
$$

2

1.225

$a+b 2^{n}=1.225$

4

1.583

$a+b 4^{n}=1.583$

8

3.665

$a+b 8^{n}=3.665$

$$
\begin{aligned}
2^{\mathrm{n}} & =-\frac{2}{.} \cdot \frac{0}{358}- \pm 5.8156 \\
\mathrm{n} & =2.539 \\
\mathrm{~b} & =0.01278 \\
\mathrm{a} & =1.225-.01278 \times 2^{2.539}
\end{aligned}
$$

$$
y=1.151+0.0128 x^{2.539}
$$

A program was compiled to calculate the constants and the exponent for a number of cases. During this proess a variable for the effect of sedimert shear strength was applied. 
HYDRAULIC PISTON CORING.

On Leg 6810,000 feet of drill string was deployed and pressurized to approximately 3,000 p.s.i. which compressed the water column an equivalent $10 \mathrm{cub}$. ft. The volume of the corer piston barrel is 0.55 cub. ft. The force on the corer piston is assumed to be constant under these conditions. From shore test results the force available for coring is around $8,500 \mathrm{lb}$. when friction and orifice control are considered.

The resistance to coring (drag) increased with depth as evidenced from the operations report from Leg 68. An exponent was developed as a depth factor using the expression:

$$
\mathrm{y}=\mathrm{a}+\mathrm{b} \mathrm{x}^{\mathrm{n}}
$$

Where $\mathrm{x}=$ The coring $\operatorname{depth}\left(\mathrm{x}_{1} \cdot \mathrm{x}_{2} \cdot\right.$ etc. $)$

$$
\begin{aligned}
& \mathrm{n}=1.3+.00044 \mathrm{~J} \\
& \mathrm{~J}=\text { The sediment shear stress in } \mathrm{g} / \mathrm{cm}^{2} \\
& \mathrm{a}=\text { Constant }=1.3 \\
& \mathrm{~b}=\text { Constant }=0.01
\end{aligned}
$$

This emperical expression was developed by general determination laws connecting a set of tabular values which yielded a regular curve. The slope of the curve at regular intervals was plotted against the predicted value of the Coring Resistance, to give a straight line. A ratio of $\mathrm{L} /(\mathrm{L}-\mathrm{x})$ relating the $\mathrm{x}_{1} \ldots \mathrm{x}_{2} \ldots$ and the total length of core

\begin{tabular}{|c|c|c|c|}
\hline Sediment & $0 \mathrm{~g} / \mathrm{cm}^{2}$ & Sediment 266 & $6 \mathrm{~g} / \mathrm{cm}^{2}$ \\
\hline $\begin{array}{c}14=9 \\
2=\end{array}$ & length & Core $\begin{array}{r}10.864 \\
2=\end{array}$ & length \\
\hline 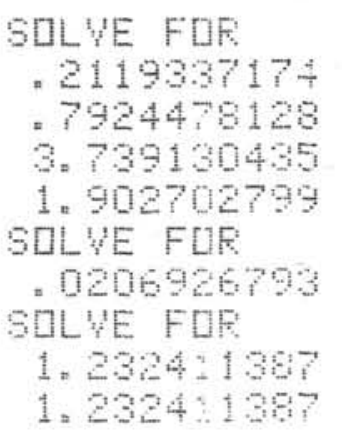 & $\begin{array}{l}\mathrm{B} \\
\mathrm{H}\end{array}$ & 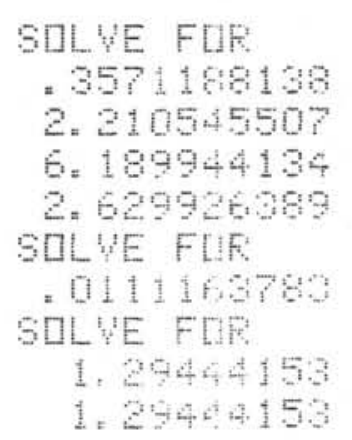 & $\begin{array}{l}B \\
H\end{array}$ \\
\hline
\end{tabular}
recovered also yielded a straight line plot, which indicated that $\mathrm{y}=\mathrm{a}+\mathrm{bx}$ might be used to provide a solution.

A program was compiled and the results of the extreme conditions reported from Leg 68 are shown. 
HYDRAULIC PISTON CORING

Background,

Designs for the Hydraulic Piston Corer (HPC.) were completed in 1978. The performance was predicted on the basis of controlling the penetration velocity between the limits of $20 \mathrm{Ft} . / \mathrm{sec}$ and $10 \mathrm{Ft} . / \mathrm{sec}$. The available shipboard rig pump pressure and flow were 2500 psi. and $350 \mathrm{gpm}$ respectively。

An expression $v=\frac{C_{d} / 2}{A 372}\left(\frac{2 g}{f}\right)^{1 / 2}[\text { Piston Force - Sediment Drag }]^{1 / 2}$ was used as an initial analytical tool.

Laboratory testing in a deep hole with a uniform sediment showed good co relation between the analysis and test. Operation in stiffer sediments indicated that the resistance to penetration increased exponentially with depth. A second "lump" factor in addition to the drag coefficient was.developed by evaluating the operational data, as previously discussed.

The drag values were based on an apparent viscosity, applicable for Ooze and unlithifide sediment, the terms used were:

$$
\begin{aligned}
& \mu=J\left(\frac{d x}{d v}\right) \\
& \text { Where } Y=\text { Sediment shear strength } \\
& \mathrm{dx}=\text { the distance between surfaces } \\
& \mathrm{dv}=\text { the velocity change } \\
& \mu=\text { viscosity }
\end{aligned}
$$

Substituting these terms in a friction equation where $\sigma=$ Sediment density $f=1.328 \sqrt{\frac{\mu}{\sqrt{(x)} \sigma}} \quad f=1.328\left(\tau / \mathrm{v}^{2} \sigma\right)^{\frac{1}{2}} \quad$ slug $\mathrm{ft}^{2}$

is obtained

Relating the friction to Hydrodynamic Drag by $D=\frac{1}{2} \sigma \mathrm{V}^{2}$ f $\mathrm{S}$ where $S$ is the surface area. A step function analysis was developed which considered each foot of corer penetration and the circumference of the barrel as a unit area. $(3.5 \pi) \mathrm{x}$ each foot of penetration allows the $\mathrm{S}$ term to be neglected numerically。

The drag term can be written $\frac{1}{2}(\sigma) \mathrm{v}^{2} 1.328\left(\mathrm{~T} / \mathrm{v}^{2} \sigma\right)^{\frac{1}{2}}$

which reduces to $D=0.664(\text { J } \sigma)^{\frac{1}{2}}(\mathrm{~V})$

then $\mathrm{V}=\frac{\mathrm{C}_{\mathrm{d}}}{\mathrm{A}} \mathrm{3} / 2\left[\text { Piston Force }-0.664(\mathrm{~T} \sigma)^{\frac{1}{2}}(\mathrm{~V})(\mathrm{D}) \exp \right]^{\frac{1}{2}}$

which is solved as a quadratic in the form of $\mathrm{aV}^{2}+\mathrm{bV}-\mathrm{c}=0$

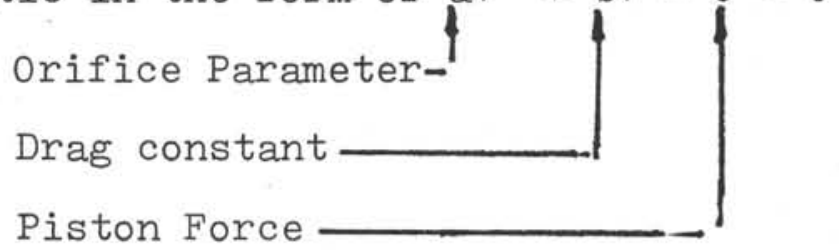

Figures 6 and 7 are analytical solutions which compare with the results obtained during actual coring operations. 
NUMERICAL EXAMPLE PREDICTING THE VALUES FOR VELOCITY AND RESISTANCE

CONDITIONS

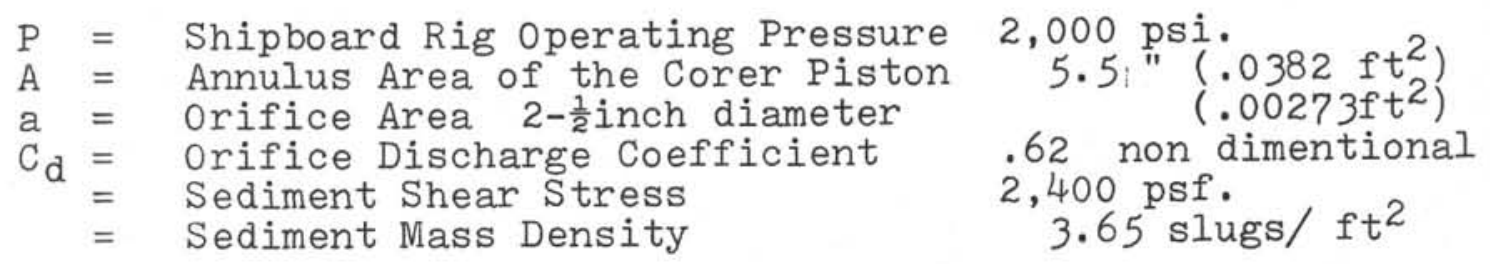

The Sediment Resitance $=.664(2400 \times 3.65)^{\frac{1}{2}}(\mathrm{~V})=61.7 \mathrm{~V}$

Then $\quad V=\frac{.00273(.62)}{(.0382)^{3 / 2}}(11000-67.7 \mathrm{~V})^{\frac{1}{2}}$

$$
\begin{aligned}
& =.2265(11000-67.7 \mathrm{~V})^{\frac{1}{2}} \\
19.49 \mathrm{~V}^{2} & =11000-67.7 \mathrm{~V}
\end{aligned}
$$

Solution of the quadratic by completion of the square

$$
\begin{aligned}
19.49\left(\mathrm{~V}^{2}+3.47 \mathrm{~V}-564.32\right) & =0 \\
\mathrm{~V}^{2}+3.47 \mathrm{~V}+(1.737)^{2} & =564.32+(1.737)^{2} \\
\mathrm{~V}+1.737 & =23.81
\end{aligned}
$$

After one foot penetration $V=22.08 \mathrm{ft} / \mathrm{second}$

The Sediment Resistance to Coring $=67.7(22.08)$

for the first foot depth

$$
=1494.81 \mathrm{lbs} \text {. }
$$

At a Coring Depth of 10 feet $\begin{aligned} \mathrm{n} & =1.3+(.00044 \times 1200)=1.828 \\ \text { Exponent } & =1.3+.01(10) \exp 1.828 \\ & =1.973\end{aligned}$

The Sediment Resistance to Coring $=67.7 \times 10^{1.973}(\mathrm{~V})$

$$
\begin{aligned}
19.49\left(\mathrm{v}^{2}+326 \mathrm{v}-564\right) & =0 \\
\mathrm{v}+163.2 & =164.9
\end{aligned}
$$

At 10 Feet penetration $\mathrm{V}=1.7$ Feet $/$ Second

The Sediment Resistance to Coring $=10,939 \mathrm{Lbs}$. 


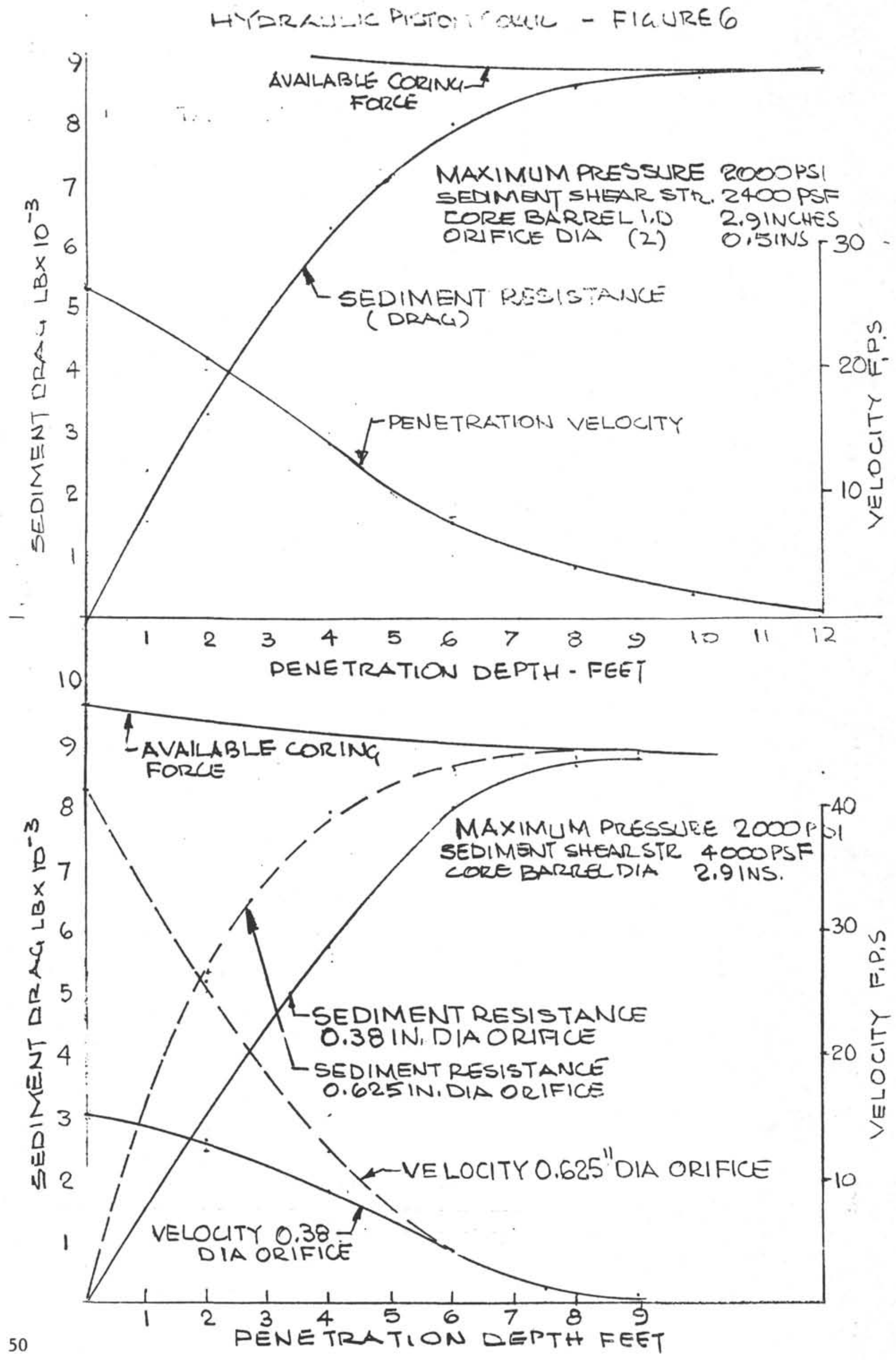


HYDRALLIC PISTON CORER FIGURE 7 MAXIMUM PRESSURE 3000 PSI

SEDIMENT SHEAR STRENGTH 1200 DSF

CORE BARREL I.D 2.90 INCHES

ORIFICE DIA METER 0.50 INCHES

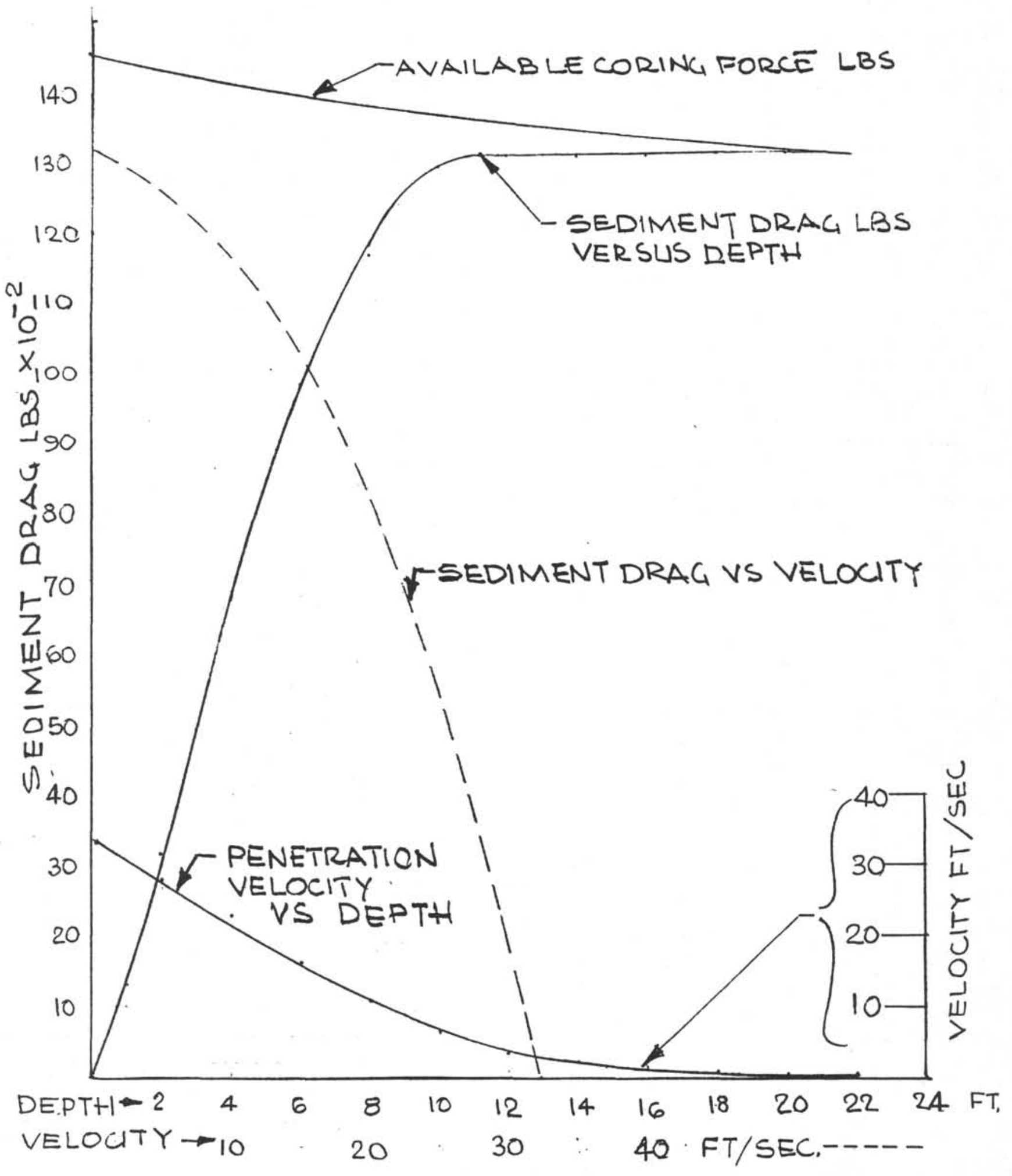


HYDRAULIC PISTON CORER

\section{ORIFICE ANALYSIS}

CONTENTS

Problem Statement

Work Done

Discussion

Conclusions

\section{Topics}

Orifice Sizing to control the H.P.C. penetration rate during coring. This control feature enables the recovery of high quality undisturbed cores to be retrieved.

An arrangement of Vent Orifices provides an efficient method for regulating the end of stroke velocity of the H.P.C, and effects a method of snubbing with reduced impact forces.

A data plot shows the decay in velocity vs the H.P.C. travel (snubbing stroke)。

Prepared by: Wil Nugent- 
HYDRAULIC PISTON CORER ORIFICE ANALYSIS

PROBLEM STATEMENT

Velocity control was a prime design factor in the development of the Hydraulic Piston Corer. A method for regulating the rate of penetration of H.P.C. into a variety of sub-surface foundation materials was essential.

The procedure should be accomplished at the assembly or redress of the H.P.C. on the drill deck.

Protection against impact damage as the H.P.C. is scoped out to the full extended length should be provided.

\section{OBJECTIVES .}

Modification of the H.P.C. consistent with operation requirements, shear pin release, and related configuration build-up, should be accomplished in the sea state environment, from the drill deck.

WORK DONE.

The velocity control is accomplished by discharging the fluid through an orifice in the Lower Chamber.

The Expression:

$$
\begin{aligned}
& v=\left(\frac{C_{d a}}{A^{3} / 2}\right)\left(\frac{2 g}{p}\right)^{\frac{1}{2}} \\
& v=c_{d a} \sqrt{\frac{2 g}{p}}
\end{aligned}
$$

is derived from

The piston Force is the product of the pressure and the area.

The Drag is a function of the dynamic impact pressure when penetrating the sediment.

The snubbing orifices function to reduce the rate of displacement of the H.P.C. barrel at the end of the end of the stroke, thus alleviating the impact forces.

DISCUSSTON

The results of the orifice analysis indicate that the H.P.C. can be equipped with a range of velocity control orifices for both sediment penetration control, and end stroke impact avoidance. 


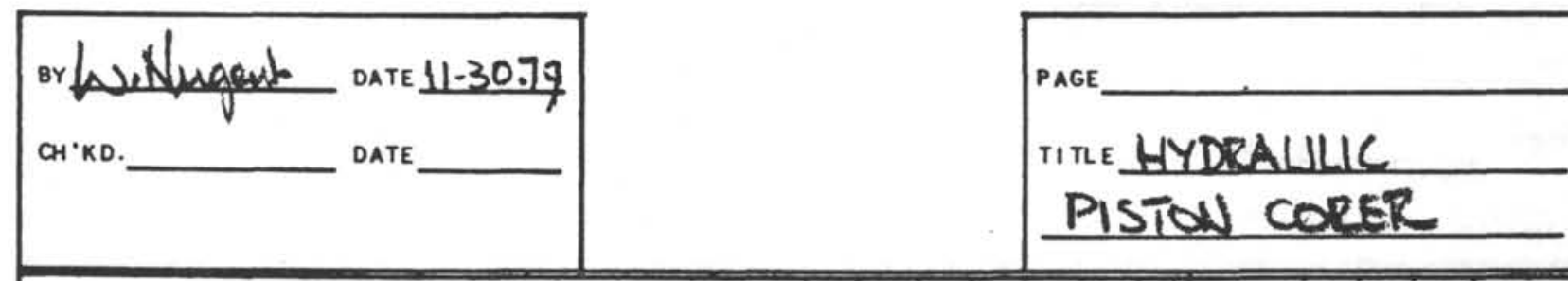

HYDRAULIC PISTON COKER ORIFICE REVIEW. .

1. CONTROL OWIFICES IN THE UPPER SHAMBER

BETWEEN THE OUTER BCDY EI THE UPPER SHAFT.

2. THE ORIFIE S FUNCTION THROUGHDUT THE ACTUATION, THAT IS, THE COMEHUED DISGHARGE RATE CONTROSS THE RATE OF PENETRATIOU. THEREFORETHE OQIFICES ARE SIZED TO PERFORM THAT FUNUIION.

3. SNUBBING ORIFICES LOLATED AT THE END OF THE TELESCOPING OUTER BODY ABOVE THE STATIONARY PISTON ENABLE VELOCITY CONTROL. AND DAMPILA TO BE AORO MPLISHED SIMULTANEOUSLY.

E.G. WHEN THE FIRST HOLE-IN-LINE PASSES BELOW THE PISTOH, FLUID DISCHARGE FROM THE UPPER CHAMBER \& ABOVE STATIONARY PISTON, PRODUKES DAMPING. THE FIRST HOLE-IN- LINE NOW BELOW THE PISTON BLEEDS RIG FLUID \& PRESSURE. THE RESULT: REDUCED FORCE ON THE PISTON, REDUCED DISPLACEMEN: ANO REDUCED DISCHARGE RATE FROM THE UPPER CHAMBER, (REF FIGURE 1) REPEATING THIS SEQUENCE WITH 4 OR 5 ORIFICES PROVIDES AN EFFECTIVE CONTROL DEVICE.

4; THE CONTROL OCCURS AT THE END OF THE STROKE, THE SNUBBINGORIFICES HAVE CAPABILITY TO REDUCE THE VELOCITY TO $15 \mathrm{FT/SECOND}$ FROM $46 \mathrm{FT} /$ SECOND WITHIN 6 INCHES OF STROKE

5. THE RESLITS OFTHE ANALYSIS ARE SUMMERIZEDIN FIG 2

6. ESTIMATE THAT IMPACT FORCE CAN BE CONTROLLED over THE LAST 0.5 INCH OF STROKE $K E=\frac{12 \times 400}{2}=2400 \mathrm{FT} L B$

FORCE $=60,000 \mathrm{LB}$. 


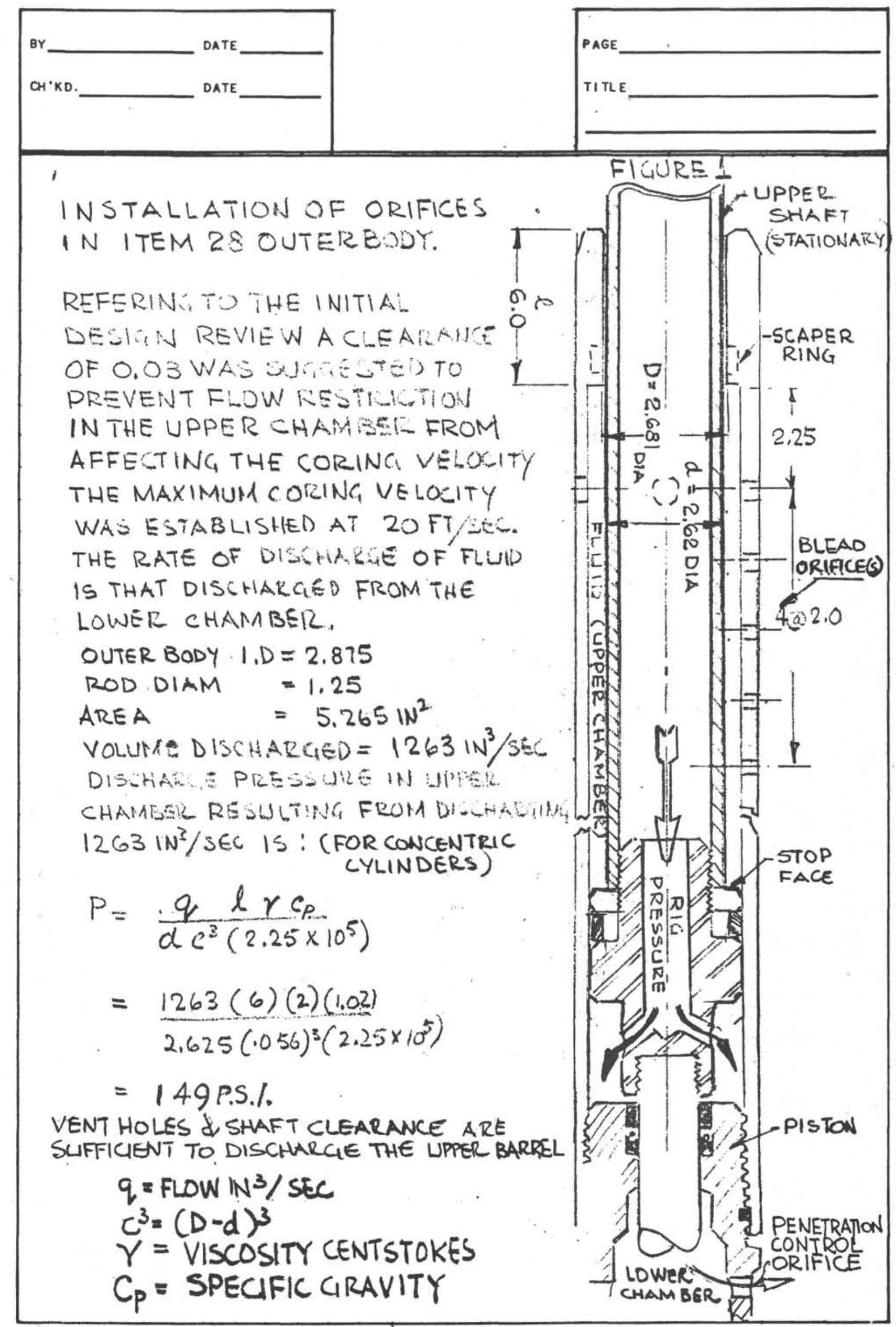




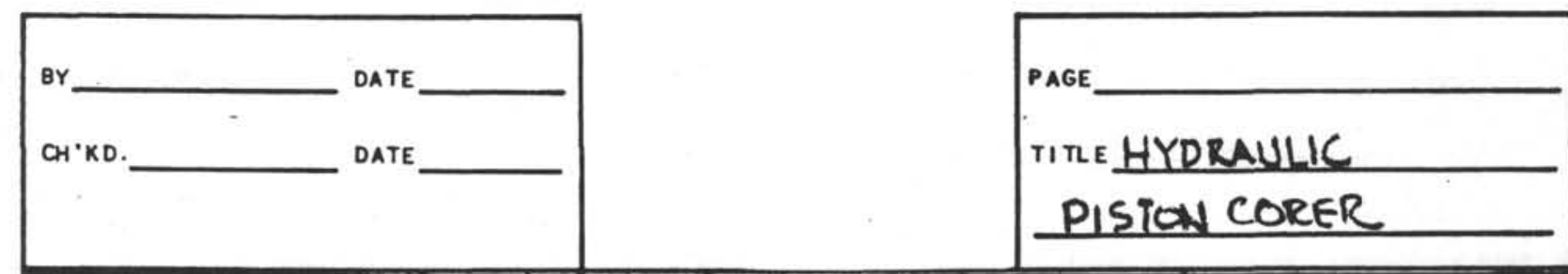

\section{SNUBBING ORIFICE ANALYSIS}

CONDITION: TAKING A CORE IN SEA WATER.

PRESSURE. $=3000$ P.S.l

PISTON AREA (ANNLLUS) $=5.261 \mathrm{~N}^{2}\left(.03656 \mathrm{FT}^{2}\right.$ )

CONTROL ORIFICE $=2 \times 5 / 3=.0447$

$C_{d}$ ORIFICE $=.62$

SLURRYMASS DENSITY $\sigma=3,6$ SLUGS/FT'

SLURRY SHEAR STRENGTH $\tilde{q}=100 \mathrm{LB} / \mathrm{FT}^{2}$

THEN RESISTANGE TO CORING $=.644 \sqrt{(100 \times 3.6)} \mathrm{V}$

$$
\text { SAY }=15 \mathrm{~V} \text {. }
$$

$$
\begin{aligned}
V= & 13779[15,780-15 V]^{1 / 2} \\
& 7\left[V^{2}+2.14 V-2253\right]=0
\end{aligned}
$$

$$
\begin{aligned}
V^{2}+2,14 V+(1,07)^{2} & =2254,9 \\
V+1,07 & =47,48 \\
V & =46.41
\end{aligned}
$$

WSE $46 \mathrm{FT} / \mathrm{SEL}$ AS THE CRITICAL VELOUTY FOR SNUBBING.

$Q=$ FLOW IN THE CORER BARREL $=46(.03656)$ :

$$
=1,682 \mathrm{FT}^{3} / \mathrm{seC}
$$

CONSIDER VENTING THE FLOW FROM ABOVE THE PISTON TO REDUCE THE VOLUME OF FLOW IN THE CORE BARREL 
BY DATE

PAGE

$C H^{\circ} K D$. DATE

TITLE

SNUBBING ORIFICE ANALYSIS

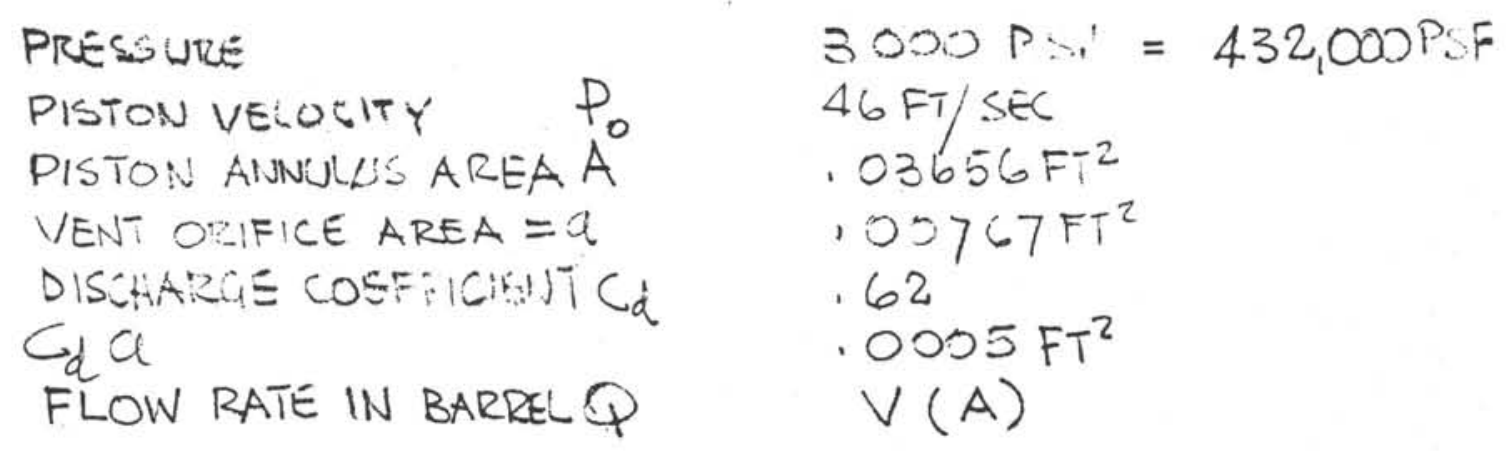

INITIAL VELOCITY 46 FT/SEC

$$
\begin{aligned}
Q_{0} & =46(.03656)=1.682 \mathrm{FT}^{3} / \mathrm{stC} . \\
q & =\text { ESTIMATE FOR FLOW THROUGH } 3 / 8 \mathrm{HINCH} \text { DI ORIFICE } \\
& =.0005 \sqrt{43,2 \times 10^{4}}=.3286 \mathrm{FT}^{3} / \mathrm{SEC} \\
v & =\text { VELOCITY THROUGH ORIFICE }=.3286 / .0005=657 \mathrm{FT} / \mathrm{SE} .
\end{aligned}
$$

WHEN THE FIRST VENT IS EXPOSED BELOW THE STATIONARY PISTON

$$
\begin{aligned}
& Q_{1}=1,682-.3286=1.353 \mathrm{FT}^{3} / \mathrm{sEC} \\
& V_{1}=1,353 / .03656=37 . \mathrm{FT} / \mathrm{SEC}
\end{aligned}
$$

SOLVE FOR $P_{1}$

$$
\begin{aligned}
37 & =.068[P-555]^{\frac{1}{2}} \\
299,082 & =P_{1}=2,077 \text { P.S.1 }
\end{aligned}
$$

WHEN SECOND VENT IS EXPOSED

$$
\begin{aligned}
C_{d a}^{a} & =.001 \\
Q_{2} & =.001 \sqrt{299082}=.547 \mathrm{FT}^{3} / \mathrm{sEC} \\
V_{2} & =1.682-(.3286+.547) / .03657 \\
& =22.06 \mathrm{FT} / \mathrm{sEC}
\end{aligned}
$$

58 
BY DATE

PAGE

CH 'TD. DATE

TITLE

SNUBBING ORIFICE ANALYSIS

SOLVE FOR $P_{2}$

$$
\begin{aligned}
& 22=.136[P-330]^{1 / 2} \\
& 26497=P=184 P . S !
\end{aligned}
$$

WHEN THIRD HOLE IS EXPOSED.

$$
\begin{aligned}
C_{d a} & =.0015 \\
Q_{3} & =.0015 \sqrt{26497}=.2442 \mathrm{FT}^{3} / \mathrm{SEC} \\
V_{3} & =1.686-(.3286+.547+.2442) / .03656 \\
& =15.37 \mathrm{FT} / \mathrm{SEC}
\end{aligned}
$$

SOLVE FOR $P_{3}$

$$
\begin{aligned}
& 15.37=.2139\left[P-15(15,37]^{1 / 2}\right. \\
& 5391=P_{3}=37.43 P .5,1
\end{aligned}
$$

FINAL VENT 4-0.5IN DIS HOLES EXPOSED

$$
\begin{aligned}
c_{d a} & =.0074 \\
Q_{4} & =.0074 \sqrt{5391}=.5433 \\
V_{4} & =1.682-(.3286+.547+.2442+.5433) / .03656 \\
& =0.517 \mathrm{FT} / \mathrm{SEC}
\end{aligned}
$$

FORM NO. 1360-0

59 
CHART NOZ

SNUBBING CHARACERISTICS

CONDITIONIS: 3000 PSI RIG PRESSLILE

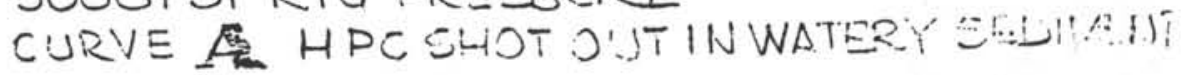

CURVE B CORING IN 400 PSF SEDIMAENT NUITH

I5FT H.P.C.

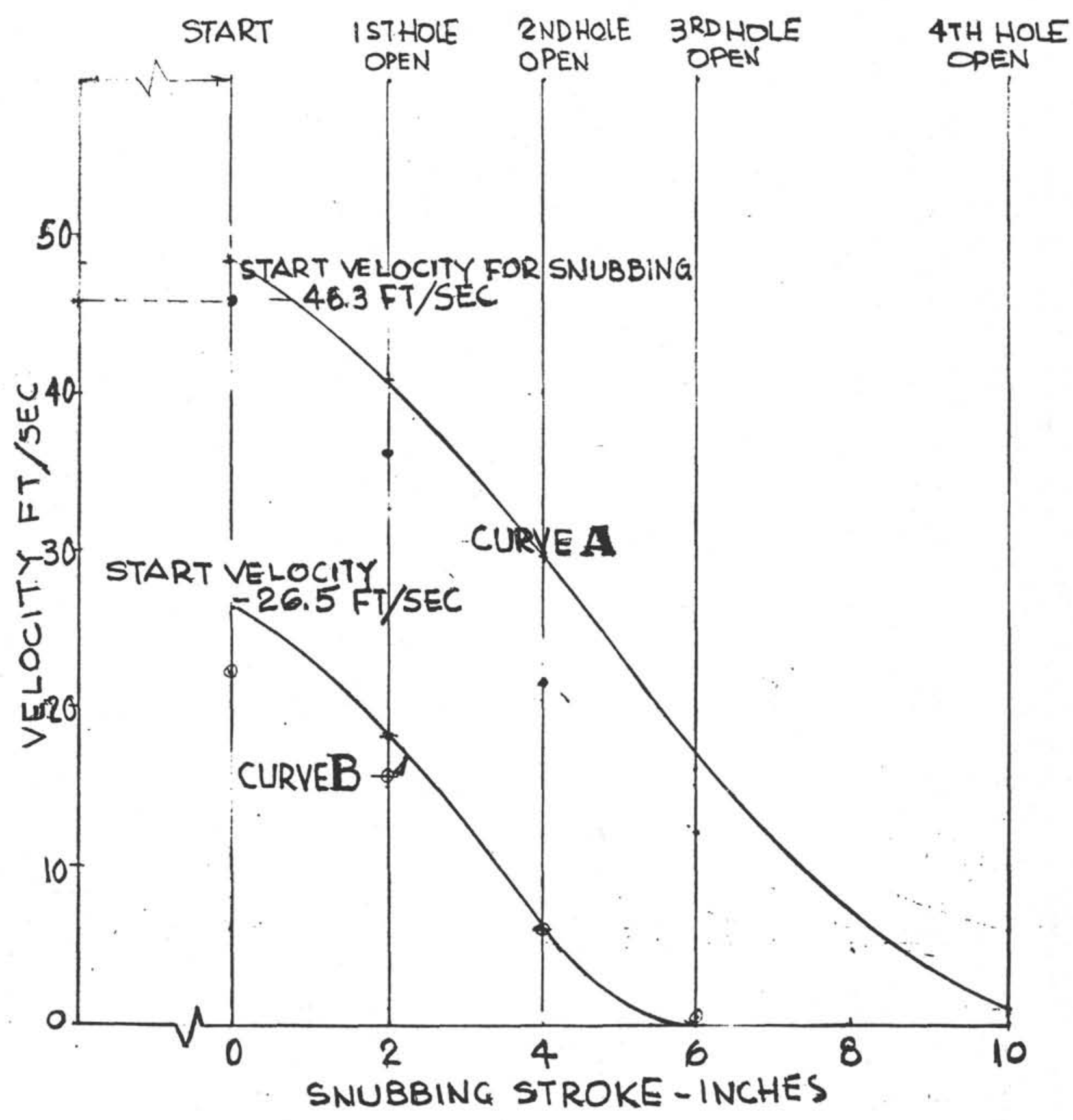

r.: 15

Het $\div-1200$. 
HYDRAULIC PISTON CORER

STRUCTURAL ANALYSIS

CONTENTS

Problem Statement

Work Done

Discussion

Conclusion

Topics

Beam-Column Analysis of the Drill Collar and extended H.P.C. Corer Barrel.

Flexural Model Test. A unit load applied on a scale model to demonstrate the deflection characteristics of the H.P.C.

Froude Scaling Techniques applied to predict the magnitude of the full scale H.P.C. structural loads and stresses.

A Moment Distribution Analysis for the scoped-out H.P.C 9 M column.

A parametric analysis for varying distributed transverse loads Shows H.P.C. barrel length vs stress due to axial and transverse load application.

Prepared by: Wevel Nugend. 
Problem Statement

Requirements for coring into increasingly stiff sediment introduced the posibility of slant angle penetration, or other related conditons which could produce side load effects in addition to column loading. The increase in stresses on both the H.P.C. components and the drill collar were considered critical.

Ob,jective

The objective of the analysis was to :

Predict the ability to recover long cores in stiffer sediment.

Preclude the possibility of yielding the H.P.C. core barrel thus preventing the retrieval of the H.P.C. through the drill pipe.

Providing guidelines for safe operation.

Work Done

A Beam-Column analysis was made to determine the combined bending characteristics of the H.P.C. and the Drill Collar. Particular attention was given to the location where the H.P.C. barrel exited the Drill Collar.

The Upper Shaft of the H.P.C. and the stationary piston were analyzed for similar loading conditions by moment distribution methods.

Scale models of equivalent dimensions were tested with axial and transverse loads applied. The reaction at the supports and contact points were observed and measured.

A Froude Scaling technique was used to calculate comparative values for full scale conditions.

Discussion

The results of these analyses and tests are presented herein. A parametric study was made which used the beam-column analysis approach to indicate the penetration depth ( H.P.C. corer length) and differential side loading capability within the limits of the corer barrel yield stress.

Conclusions.

The analysis and the test show good co relationship considering that the model unit load test produced a 7.5 inch deflection and the analysis developed a 10.5 inch deflection.

The H.PC. core barrel and stationary upper shaft have sufficient flexural stability to be considered suitable for use in a 9 meter ( 30 Feet long) coring tool. 
9.0 M. H.P.C. SCORED OUT

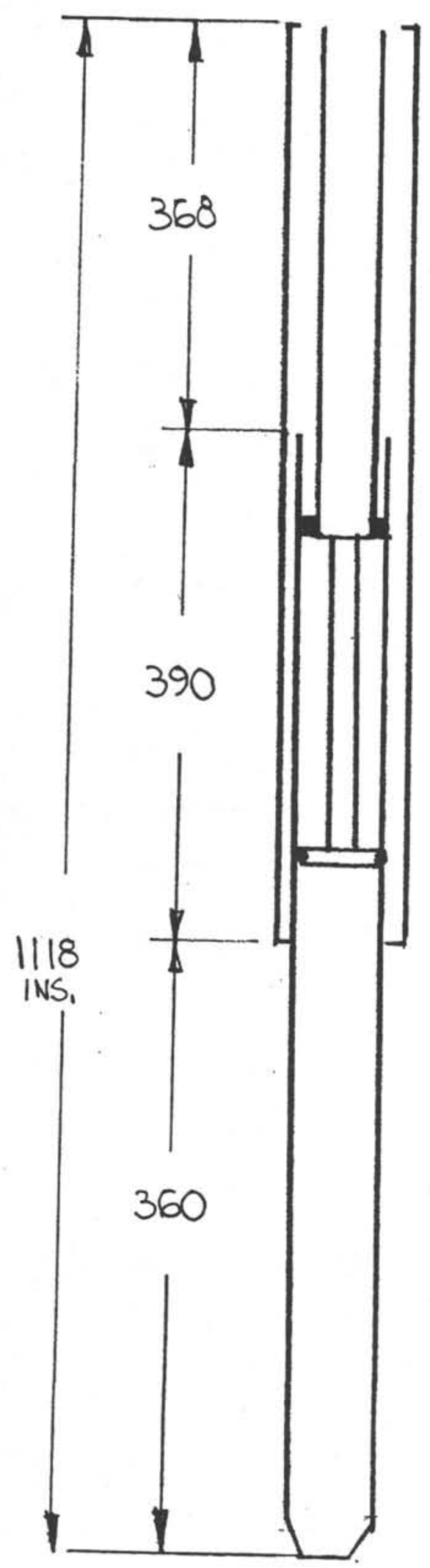


HY DRALLIC PISTON CORER STRUCTURAL ANALYSIS CORE BARREL ANALYZED AS A BEAM COLUMN CONDITIONS:

PISTON EXTENDED 30 FEET

END LOAD $=12,044 \mathrm{LB}$.

DIMENSIONS OF CORE BARREL

3.50 O.D: 2.875 I.D. ANNULUSAREA $3.1293 \mathrm{IN}^{2}$

$I=4.005 \mathbb{N}^{4}, Z 2.2886 \mathrm{NN}^{3}, \ell=1.1323 \mathrm{IN}^{2}$

DIMENSIONS OF DRILL COLLAR

$4.750 .0,4.12$ I.D. ANNULUS AREA $4.357 \mathrm{IN}^{2}$

$I=10.82 \mathrm{iN}^{4}, Z=2.473 \mathrm{iN}^{3}, P=1.576 \mathrm{iN}^{2}$
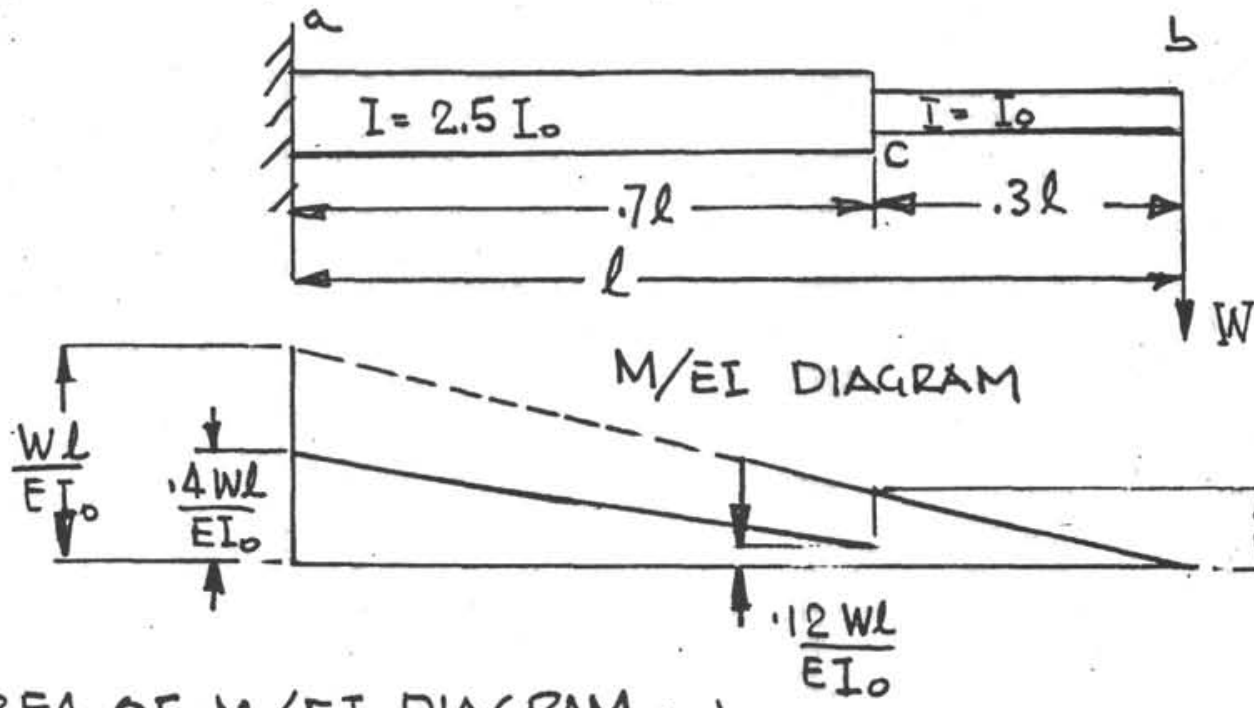

AREA OF M/EI DIAGRAM $a-b$

$$
\text { EIo }
$$

$\theta_{b}=1 / 2\left(\frac{.3 W l}{E I_{0}} \times .3 l\right)+\left(\frac{.12 W l}{E I_{0}} \times .7 l\right)+1 / 2\left(. \frac{28 W l}{E I_{0}} \times .7 l\right)$

STATICAL MOMENT

$\delta b=\frac{1}{E I_{0}}[1 / 2(.2 l)(.3 W l)(.3 l)]+\left[.35 l(.12 W l)(.7 W l)+\left[\frac{1}{2}(.77 l)(.28 W l(.7 l)]\right.\right.$

$=\frac{1}{E I_{0}}\left[.009 \mathrm{Wl}^{3}+.0294 \mathrm{Wl}^{3}+.07546 \mathrm{Wl}^{3}\right]$

$=\frac{.11386 \mathrm{Wl}^{3}}{E I_{0}}=$ DEFLECTION DUE TOW

$E Q 1$ 


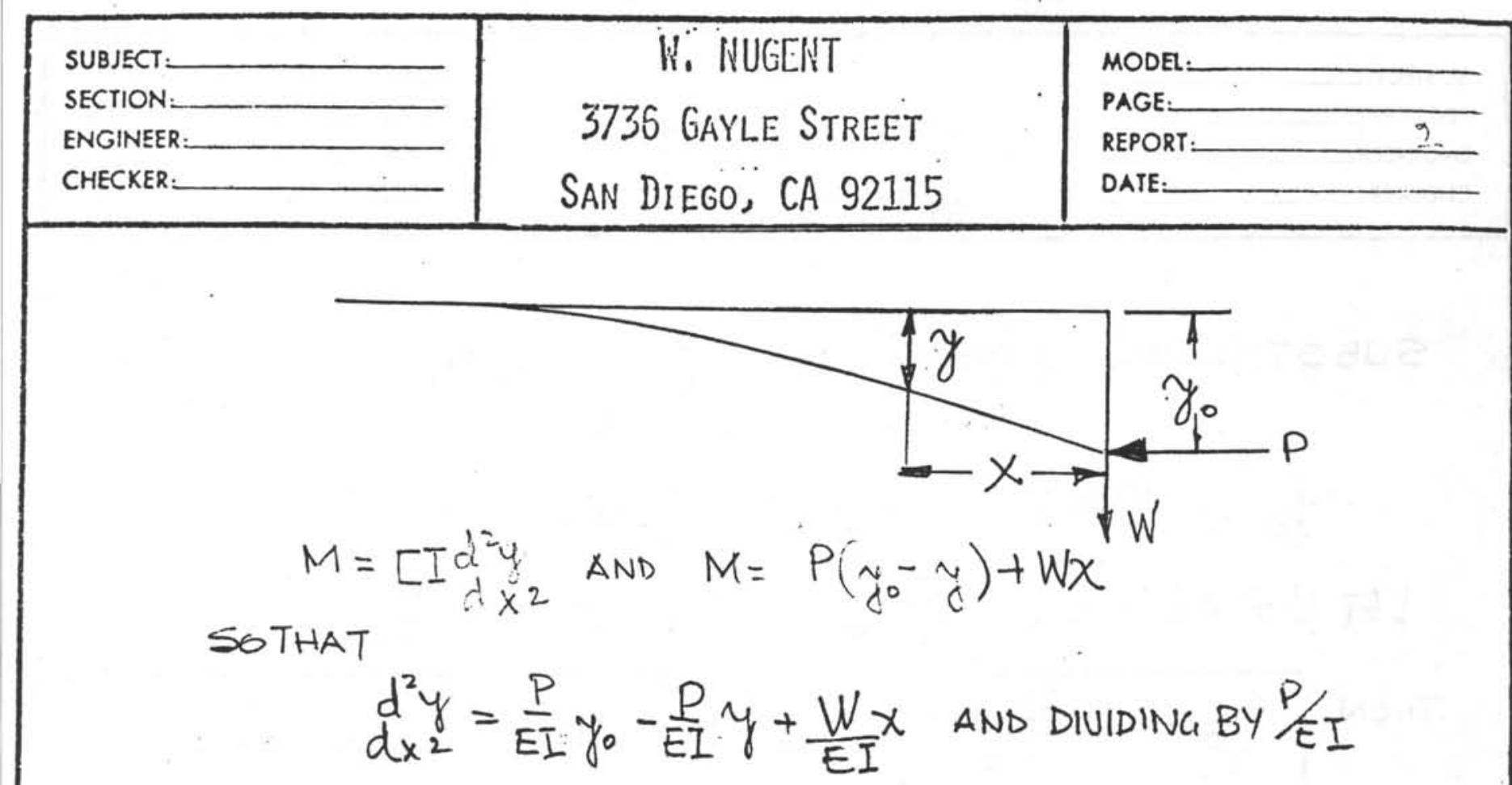

ANDUSING ASA SOLUTION $y=\Delta \sin W_{x}+B \cos W_{x}+\frac{W_{x}}{P}+y_{0}$ EQ 2

$$
\begin{aligned}
\frac{d^{2} y}{d x} & =-W^{2} A \sin W x-W^{2} B \cos W x \\
& =-W^{2}(A \sin W x+B \cos W x) \cdot W \text { HEN } W^{2}=P / E I
\end{aligned}
$$

AND WHEN $x=l, y=0$, THEN $\frac{d y}{d x}=0$; WHEN $x=0 \quad y=y_{0}$

$$
\begin{aligned}
\therefore \quad 0 & =A \sin W l+B \cos W l+\frac{W l}{P}+y_{0} \quad A N D \\
0 & =W A \cos W l-W \sin W l+\frac{W}{P} \\
y & =0 \quad-B+y_{0} ; s_{0} B=0
\end{aligned}
$$

AND $A=\frac{W}{P W \cos W l^{A L S O}} A \sin W l=\left(-\frac{W}{P W(\cos W l)}\right) \operatorname{sm} W l$ THEN $\frac{W}{P W} \tan W l+\frac{W l}{P}+y_{0}=0$ or

$$
\begin{aligned}
& y_{0}=\frac{W}{P}\left(\frac{\tan W l-W l}{W}\right) \text { NOTE }_{E I} \frac{P}{W}=W^{2} \& \frac{P l^{3}}{E I}=W^{2} l^{3} \\
& y_{0}=\frac{W}{P} \frac{P l^{3}}{E I}\left(\frac{\tan W l-W l}{W^{3} l^{3}}\right) \quad E Q .3 .
\end{aligned}
$$

65 


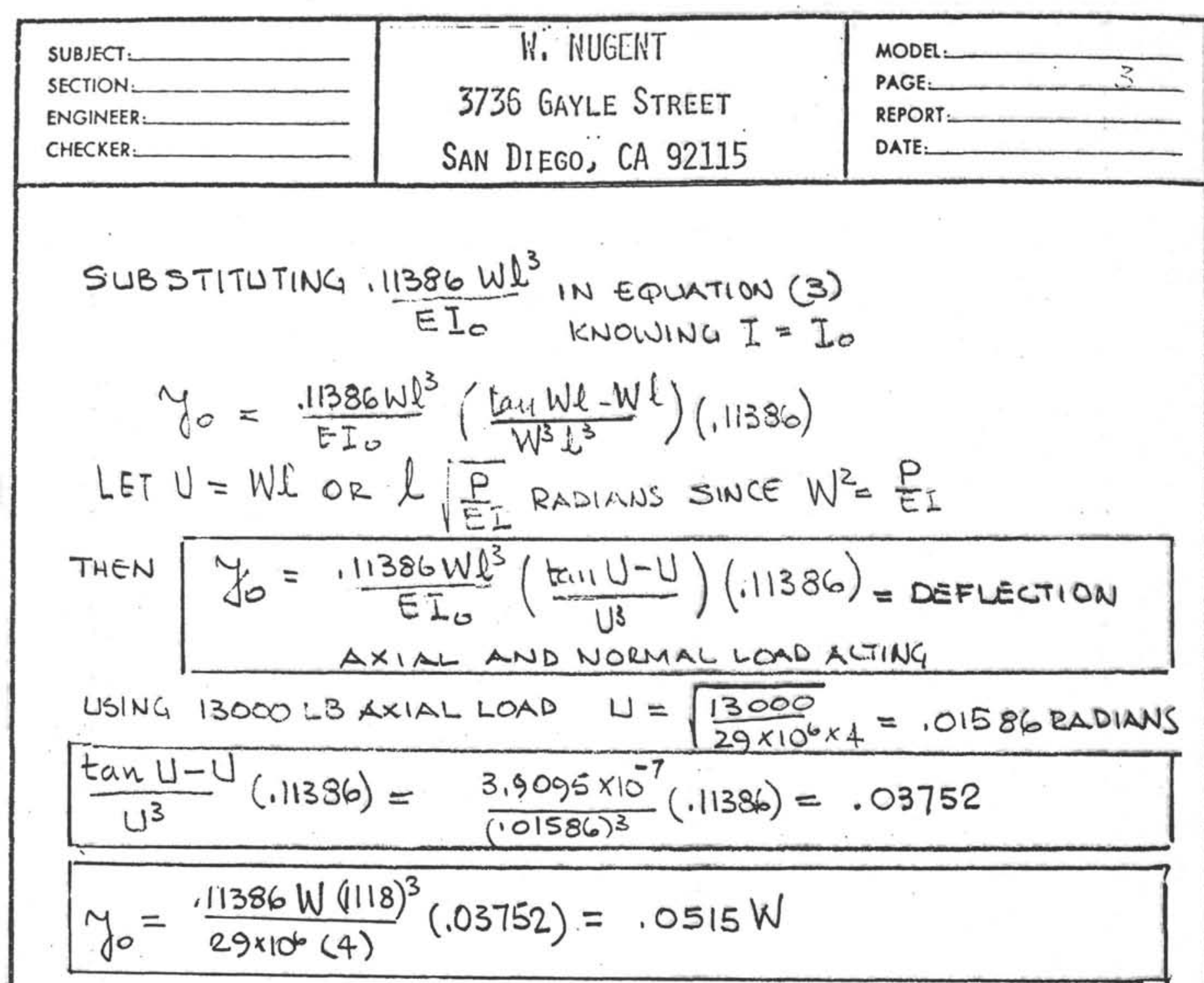

BENDING MOM. ON HP,C DRILL COLLAR

AXIAL LOAD $=13,000 \mathrm{LB}$

TRANSVERSE LOAD APPLIED AT $W=150 \mathrm{LB}$.

$$
\begin{aligned}
B, M=P y_{0}+W l & =13,000(.0515) 150+150(1118) \\
& =268,125 \mathrm{IN} \mathrm{LB} .
\end{aligned}
$$

BENDING MOMENT ON H,P.C PISTON (STEP ' $C$ ')

REF.' M/EI DIAG. , $\frac{4 W l}{E I}$ MAX BM. . $\frac{3 W l}{E I}$ BIM AT STEP'C'

$$
\begin{aligned}
& B . M=268,125(3 / 4)=201,004 I N \cdot L B \\
& f_{b}=\frac{201,094}{4} \times 1,75=87,978 \text { PSI. }
\end{aligned}
$$

66 


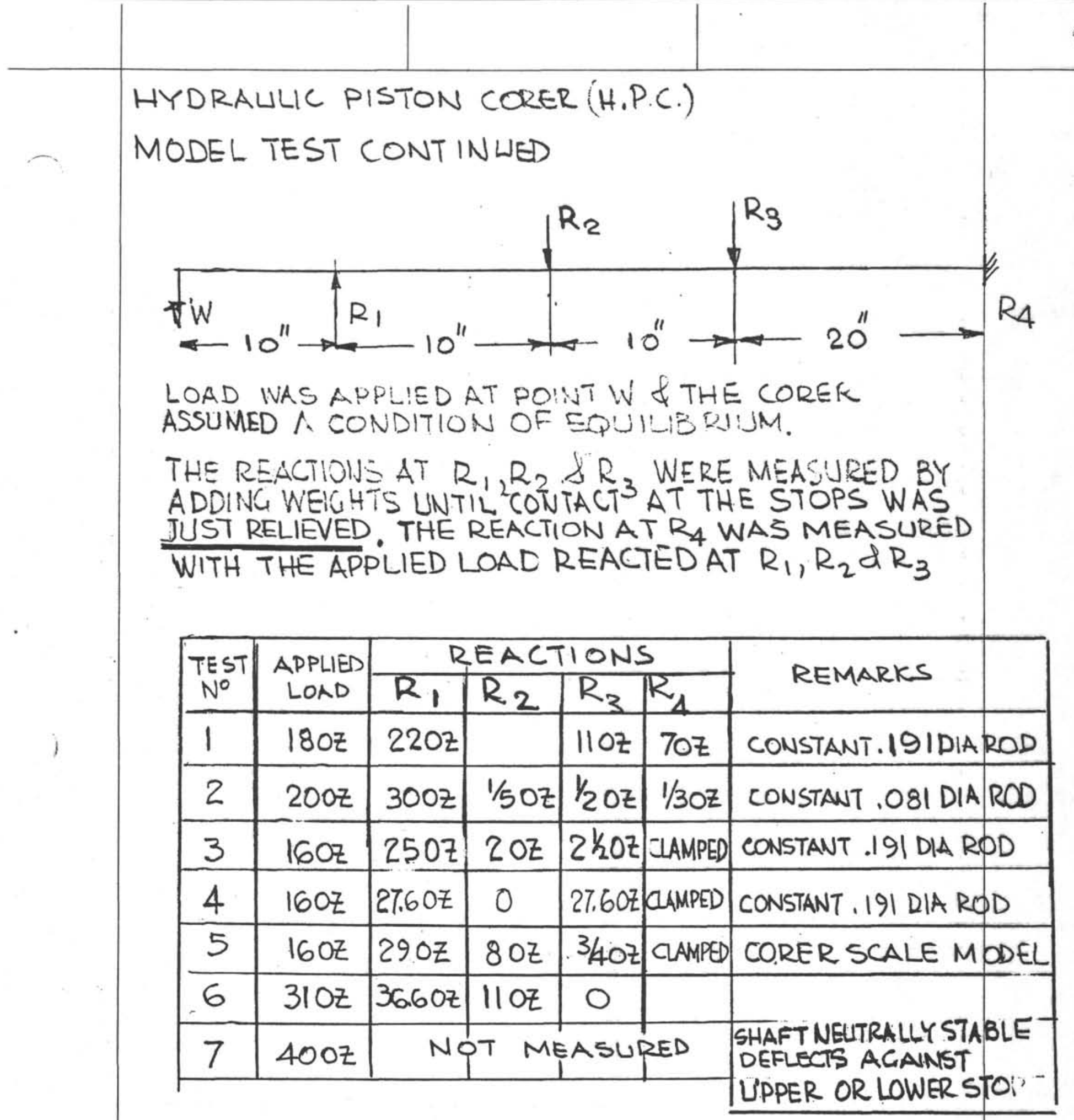

THIS TEST TENDS TO INDICATE THAT THE FORCE \& MOMENT DISTRIBUTED TO THE UPPER SHAFT IS RELATIVELY SMALL COMPARED TO THAT EXISTING AT THE DRILL BIT. 


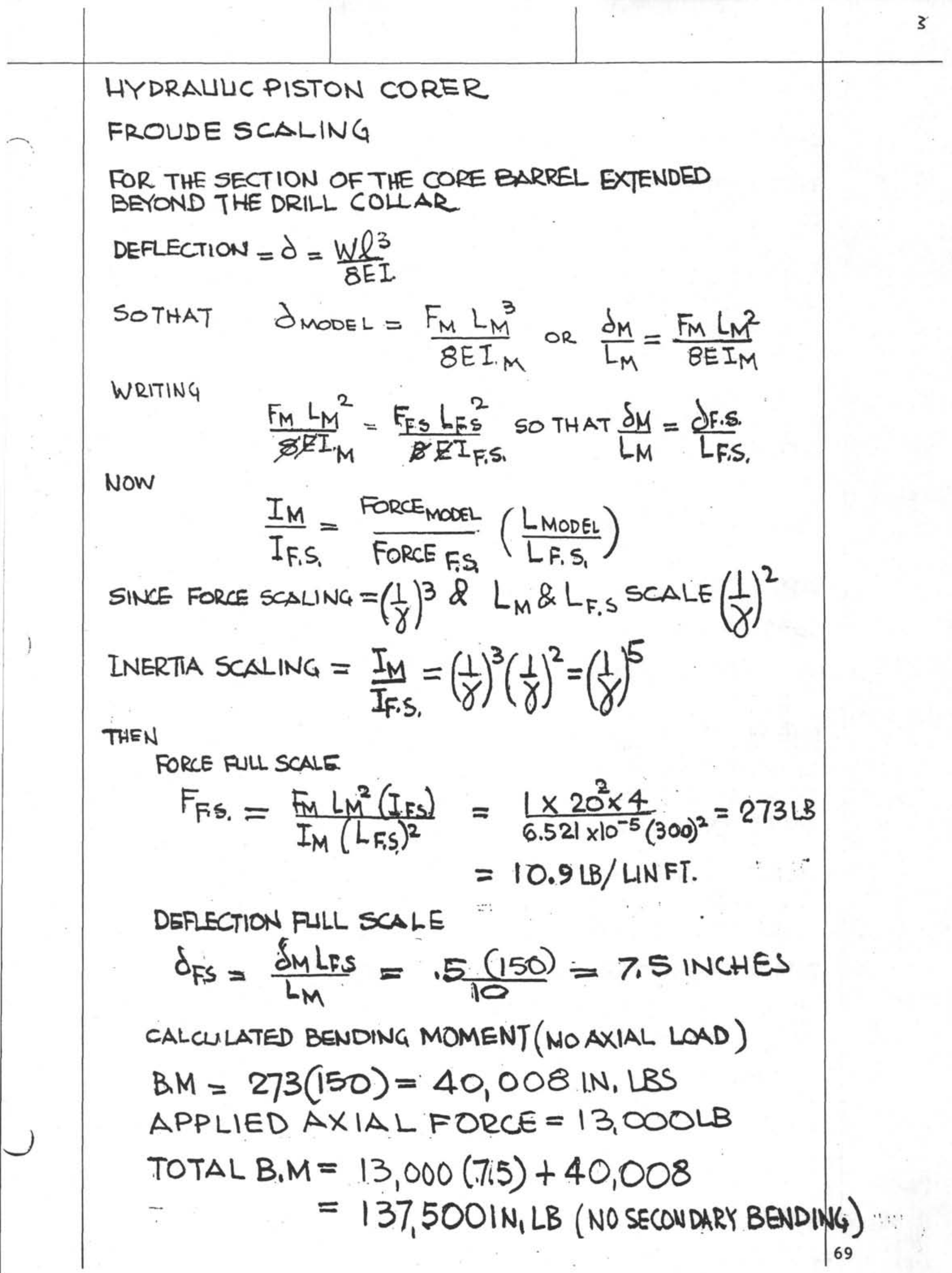




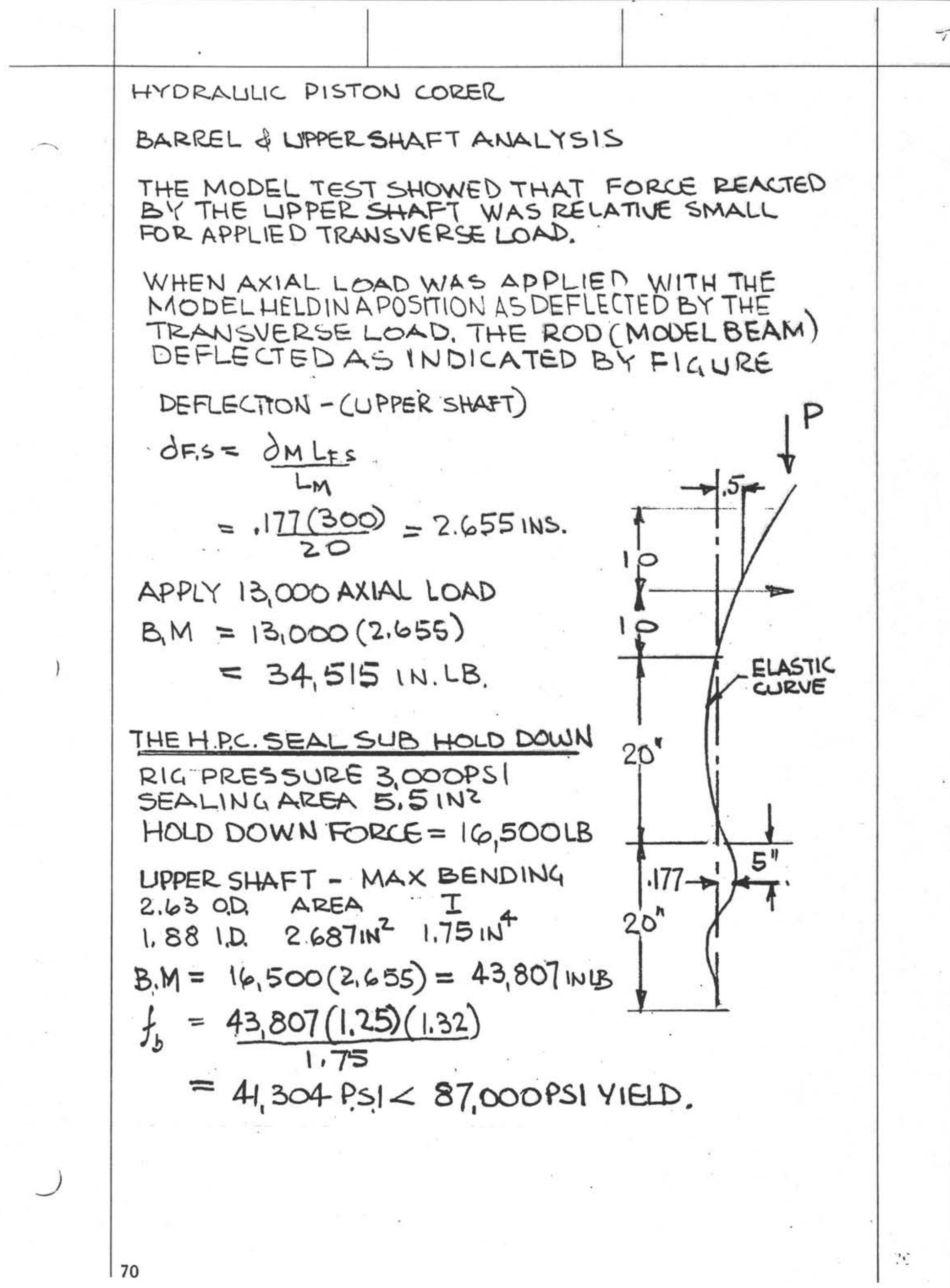




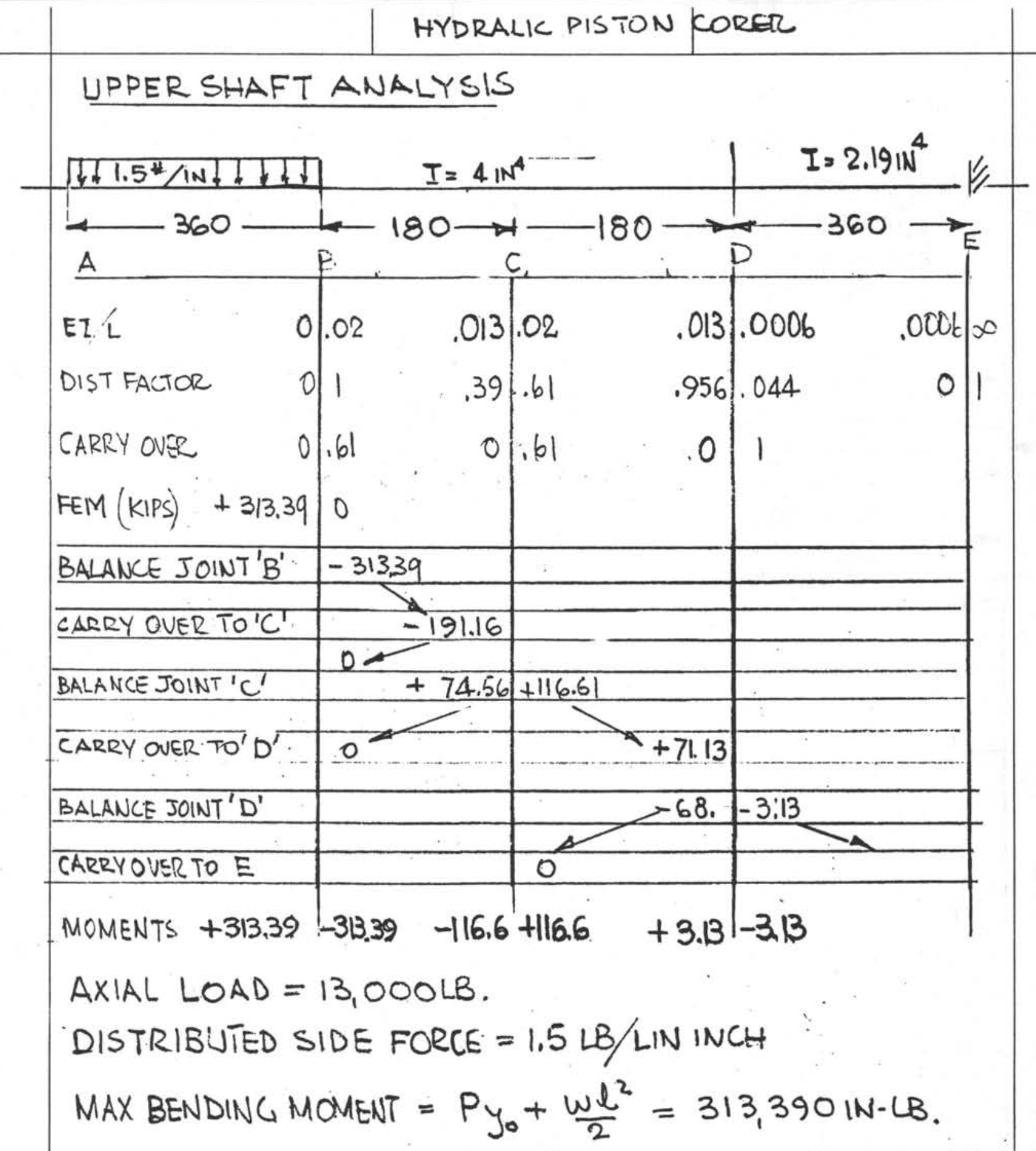

DERIVATION OF, CONSTANTS (CORRECTION FOR STIFFNESS FACTOR) REFERENCE: BRUIN ENE. AIRCRAFT STRUCTURES A,11,21. 1952

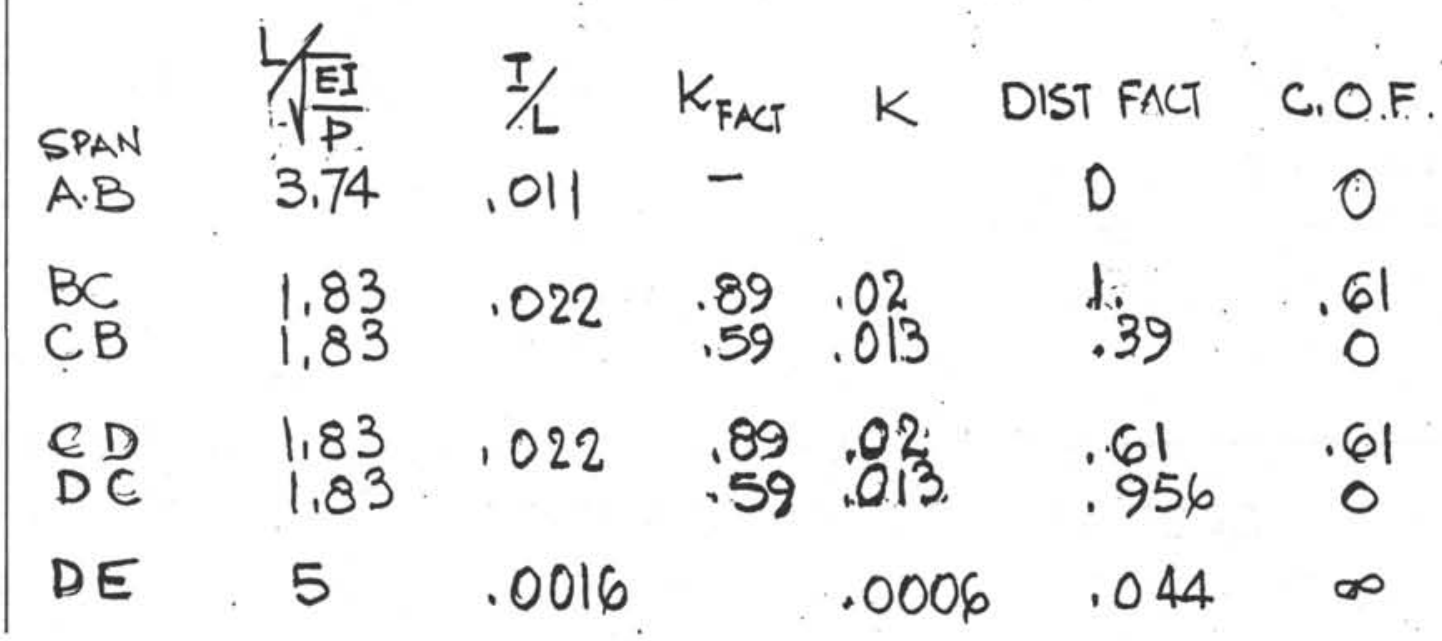




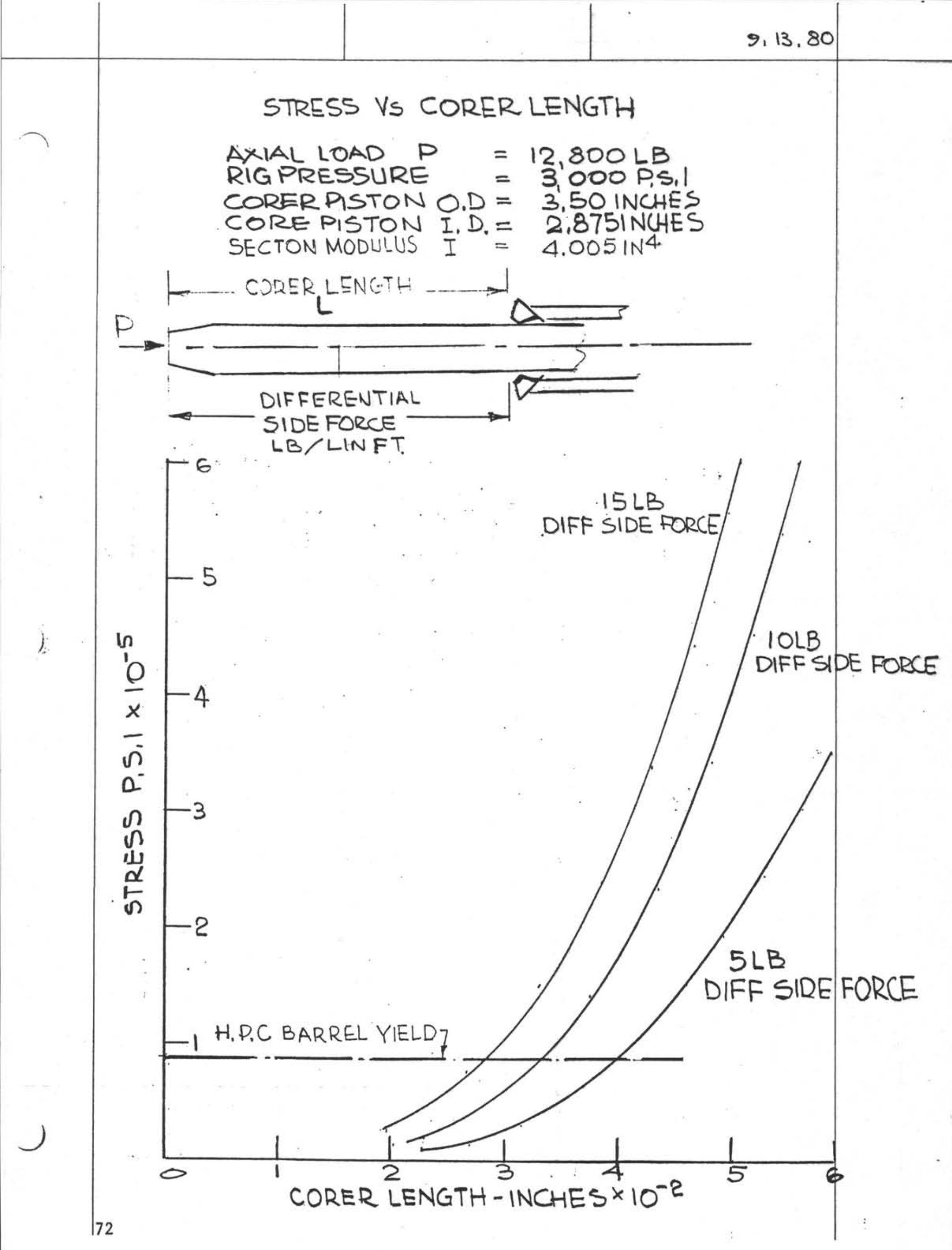


HYDRAULIC PISTON CORER

THREADED CONNECTIONS ANALYSIS

CONTENTS

Problem Statement

Work Done

Discussion

Analysis Summary

\section{Topics}

Taper threads in relatively thin section pipe. Methods for reacting couping forces by shoulder abuttment.

The effects of reduced cross sectional area due to thread relief and pressure seal grooves.

The effects of "snatch" forces during H.P.C. make up and redress. Stopping of the travelling mass when taking inadvertent water cores. Corrosion alleviation by substituting Nimonic stainless steel.

Prepared by: Wil Wuegent 


\section{PRO BLEM STATEMENT}

The connecting thread elements used in the H.P.C, are generally consistent with thosed used in the drill string. In the H.P.C. function there are additional loads applied to the threads which result from load reversal, impact stop forces and pull-back. The available envelope ( diameter of the drill collar and spacing of the components) is a constraining factor。

Lengthening of thread engagement can be accomplished without severe change to the configuration. The critical regions are in the area of thread relief, necessary to achieve shoulder-to-shoulder abutment, and the recesses for the seal rings.

The alleviation of corrosion and the substitition of material to meet that objective was were also included.

\section{O BJECTIVES}

The object of the analysis was to determine the feasibility of using corrosion resistant metal which may have lower working yield stress capability. The purpose was to investigate potential improvement in service life of the H.P.C., to reduce the time to redress the components between sucessive coring deployment; to improve the cost effectiveness and life expectancy of the equipment.

\section{Work Done}

Nimonic 60 stainless steel was proposed in an effort to combat corrosion and improve operational turn-around for the H.P.C. Particular attention was required in the areas of undercutting and recessing which create "notch sensitivity" especially when impact and load reversal conditions apply. These critical sections were subjected to detail analysis. The end stroke snubbing which involves methods for venting pressure and discharging the flow of fluid through drilled holes in the barrel had significant impact on the analysis.

\section{Discussion}

The analysis indicates that Nimonic 60 stainless steel in the mill condition was satisfactory but a reduced margin of safety resulted. The impact design case used showed the inner seal sub to have a negative margin. The condition can be solved by improvement in the snubbing system. A summary of the results of the analysis is included along with recommendations for limiting the applied pull-out force. 
CY.KD.

PAGE

TITLE

SUMMARY OF ANALYSIS

ITEM DWGNO DESCRIPTION

REMARKS

31 $1084 \quad$ TOPSUB BOOY

REF PAGE ।

CONTROL IMPACT $=70 O O L E$

STRESS ON THREAD

CONNECTION TO LIPPER SHAF"

$f_{t}=42,169 \mathrm{PSI}$

MARCIIN $=1.3$ ON YIELD

FOR NITRONIC 6OS.S

$271210 \quad$ SHAFT

1213

UNDER CUT GROOVE FOR

SHEAR PIN.

2.36 DIA - 1.875 DIA

IMPACT FORCE $=70,000 \mathrm{LB}$

43,392 P.S.I.

MARGIN 1.29 ON YIELD FOR

NITRONIC 60 ST. STL.

$23 \quad 1214$ INNER SEAL SUB IMPACT FORCE $=70,000: \mathrm{B}$

STRESS ON THREAD

CONNECT WNITH 1210

MARGIN 2.7 ON VIELD FOE

NITRONIC 60 ST. STL.

IMPACT 210,000 LB

NEG 1.11 MARGIN ONYIELD

FOR NITRONIC 60 ST.STL.

111231 DOUBLE PIN SUB NOCHANGE

MARGIN ADEQUATE FOR

4130 .

8? 1212 LONER OJTER BDDY IMPACT FORCE 210,000 LB.

$$
\begin{aligned}
& f_{t}=158,447 \text { P.S.1. } \\
& \text { IMPACT }=70,000 \\
& f_{t}=52,830
\end{aligned}
$$


BY DATE

CH'KD. DATE

TITLE

ITEM

DUG NO. DESCRiPTION

REMARKS

12,16 OUTER SEAL SUB

THREAD RELIEF

IF IMPACT $\approx 70,000$ LB

$f_{t}=31,715$ P.S.l.

MAG IN ON YIELD FOR NITRONIC

STAINLESS STEEL $=1.76$

$10 \quad 1219$ PISTON ROD

LIMIT PULL OUT FORCE

1232

NOT TO EXCEED 20,000 LB.

THE CRITICAL AREAS ARE THREAD RELIEF \& UNDER CUT GLOVES.

THREAD LENGTHS CAN BE INCREASED TO PRODUCE INCREASED MARGIN.

REVIEW I AE CONTROL ORIFICES IN UPPER CHAMBER

76 


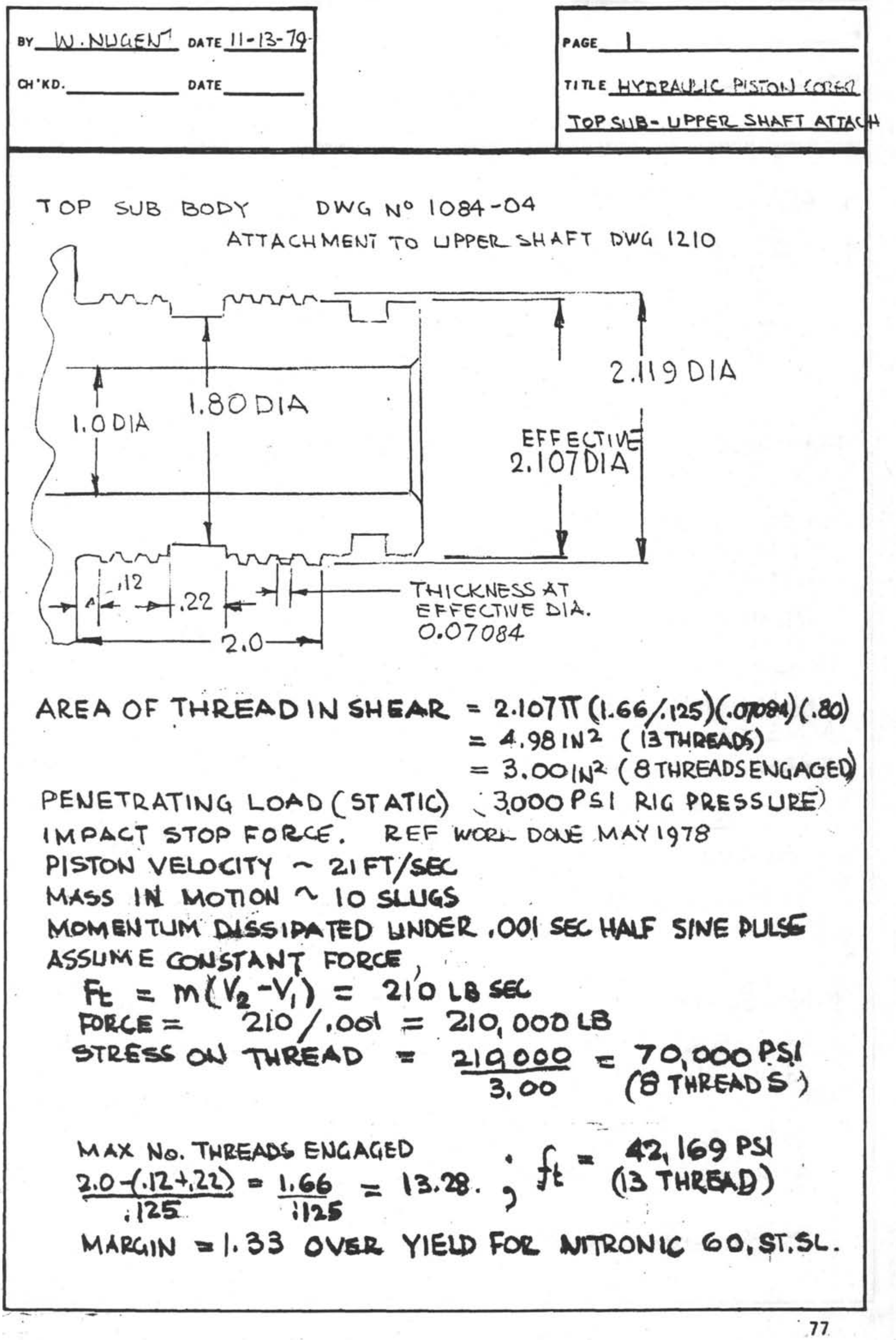




DY
ACME- 8 THREAD


UPPER SHAFT DWG 1210

LOWER SHAFT DWG 1213

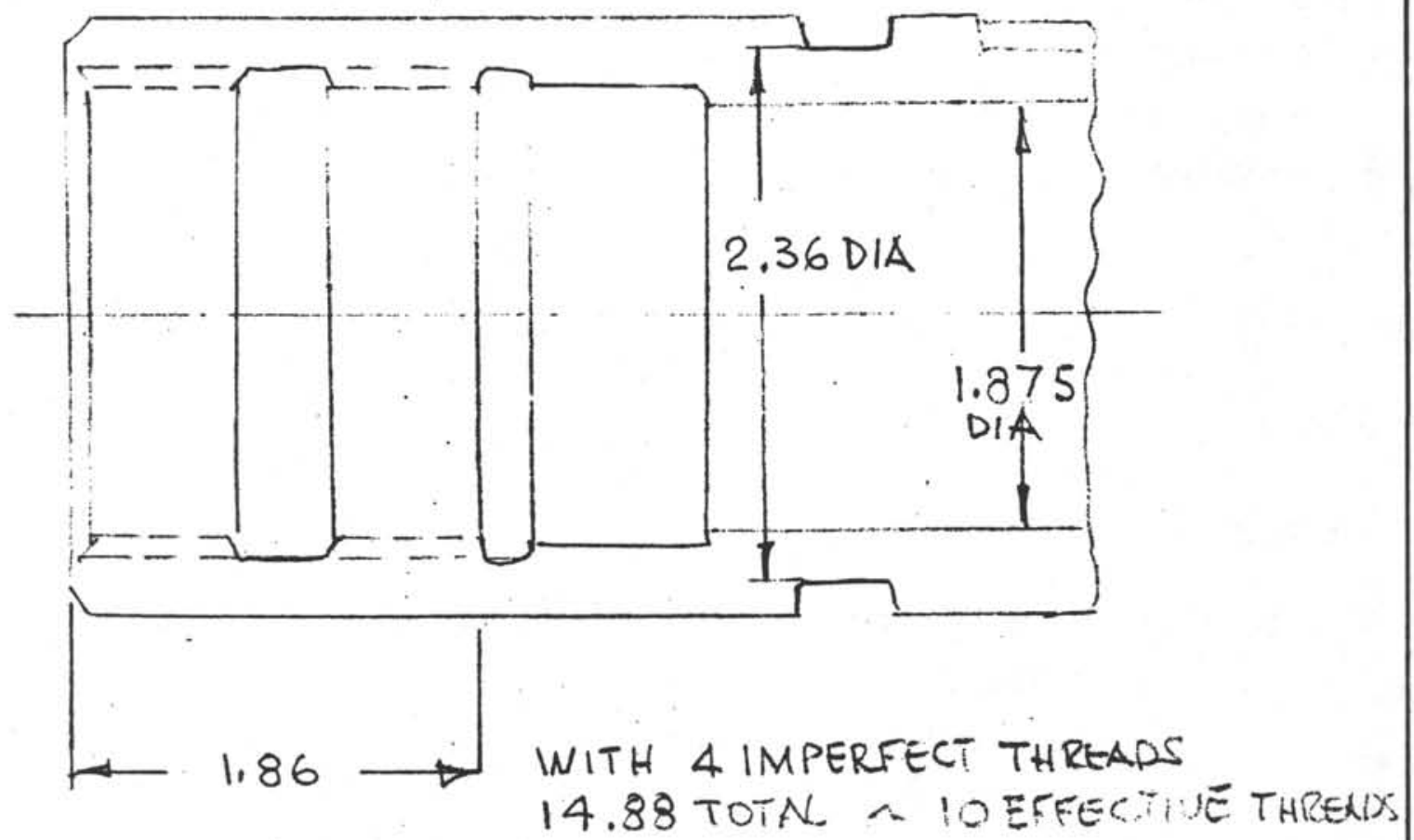

THREAD AREA $=3,75 \mathrm{in}^{2}$

1 MPACT FORCE $=210,000 \quad$ IMPACT FORCE $=210 \% .003$

$$
f_{t}=56,000 \text { P.S.I }
$$

UNDER CUT AREA

$$
\begin{aligned}
& =70,000 . \\
f_{t} & =18,667 \text { P.S. }
\end{aligned}
$$

1 MPACT FORCE $=210,000$

$$
f_{t}=130,177 \text { PSI }
$$

$1 \mathrm{MPACT}$ FORCE $=70,000$

$$
f t=43,392 P, S_{1} 1
$$

LOWER SHAFT MAY SEE SOME RELIEF FROM THE IMPACT, BUT FOR THE SAKE OF UNIFORMITY THE DESIGN WILL BE STANDARDIZED. 
CH'KD.

DATE

TITLE

INNER SEAL SUB. B. $1214-00$

THREADED CONNECTION TO UPPERSHAFT

PARTS BIZ14-DO- B $1210-00$

THREAD $2 \frac{1}{9}$ STUB ACME LENGTH OF ENGAGG MANT

$3.75-(.75+.44+1.00)=1.50$ WITH 4 DISCONTINUDUS THDS.

EFFECTHUE AREA OF THKEAO.

FULL THREADS ENGGGED $=9(2.10 \% \pi 1) \times .071 \times .80=3.3 \times 3$

corang d PULL OUT Force $\equiv 5.5(3000)=16,500$

$\begin{aligned} f_{t} & =4876 \text { PSI } \\ \text { NOT CRITICAL } & \end{aligned}$

IMPACT STOP (ASSUME SNUBBINA EFFECTIVE IN,OOB SEC)

$F_{t}=m\left(V_{2}-V_{1}\right) j=21 \times 10$ THEN

$F=210 / .003=70000 \mathrm{LB}$

$f_{t}=\quad 20,691$ PS.I. (MORE PROBABLE)

NOTE: THE EFFECT OF SNURBING "SPREADING THE IMPAG over a longer time period reduces the force BUT THAT FORCE IS STILL TO BE REACTED BY THE UPPER SHAFT.

INNER SEA SUB FOR ITEM (18) PIN

$O . D=1.795 \quad$ AREA $=1.2935 \mathrm{NN}^{2} \quad f_{t}=54.114 \mathrm{PS} /$

I. $D=1.255$ NOT CRITICAL THREADS BEAR THE LOAD.

INNER SEN SUB- ROD CONNECTION

DWG B $1214-\infty$ \& B 1217-0

PULL OUT CONDITION $=.8(16500)=13,200 \mathrm{LB}$

THREAD AREA $=1.066 \pi(1.125 / .125) \times .07084 \times .8=1.708$

$$
f t=7728 \text { P.S.1 }
$$

NOT CRITICAL 


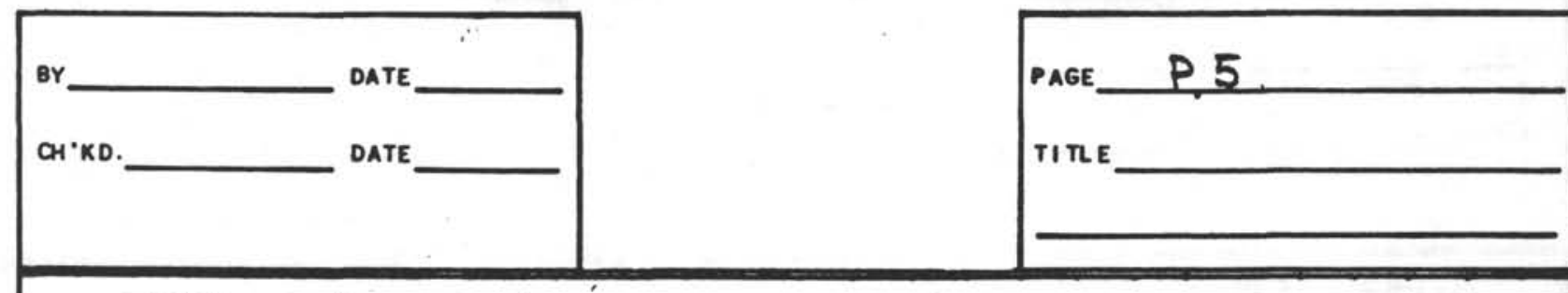

DOUBLE PIN SUB DWG,BI231-OO

ESTIMATE 5 STUBACME

THtreAD AREA $\sim 3.13 T(2 / .2)(.13)(.80)=10.3 \mathrm{iN}^{2}$ PENETRATION (STATIC ANALYSIS) $=16,500 \mathrm{LR}$

$$
\begin{aligned}
& S_{t}=1601 \mathrm{PSI} \\
& \text { NO COTICLL }
\end{aligned}
$$

IMPACT FORCE (STOO ON UPPER AMIRE )

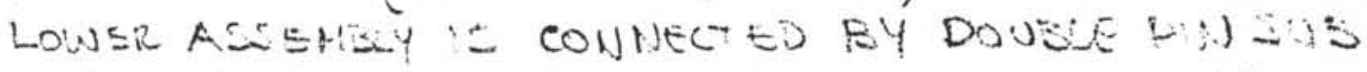
IMPACT FORCE

$$
=210,000 \mathrm{LB}
$$

$$
f t=20,388 \text { PS! }
$$

NOT CRITICAL FOR MAX IMPACT.

UNDERGUT MIL SLOTS

O.D 3.5 AREA SLOT ETFECTIVEXRE

I.D. $2.875 \quad 3.1293 \quad .165 \quad 2.96$

IMPACT $F_{t}=m\left(v_{2}-v_{1}\right)=$

IF IMPACT IS REDUCED TO

$$
\begin{aligned}
& 210,000 \mathrm{LB} \\
& f_{t}=70,842 \text { P.S.1 } \\
& 70,000 \text { LR } \\
& f_{t}=23,649 \text { P.S.1 }
\end{aligned}
$$

LOWER OUTER BODY - B1212

sIMILAR cONNECTION TO 81231 DOUBLEPIN THREAD NOT CRITICAL

LNERCUT AT THREAD TERMINATION

$$
\begin{array}{rlrl}
\text { O.D } 35 & \text { AREA IMPACT FORCE } & =210,000 \mathrm{LB} \\
I D 3.25 & 1.325 \text { ft } & =158,441 \mathrm{pS} ! \\
\text { IF IMPACT FORCE IS REDUCED TO } & =70,000 \mathrm{LB} \\
f_{t} & =52,830 \mathrm{PSI}
\end{array}
$$

THIS SECTION WAS CRITICAL IN 4130 STEEL. 
By DATE PAGE $P, 6$ OH'KD. DATE TITLE

OUTER SEAL SUB R- $1216-00$

THREAD CONNECTION TU OUTER BODY

3INCH-8-STUE ACME.

$$
\begin{aligned}
& \text { MASOn DIAn 3.O0 EFFECTIVE DIs WIDTHEFFECTIVE } \\
& \text { MINOR } 2.872 \quad 2.636 \quad 0.07084 \\
& \text { AREA IN CONTACT }=2.636 \pi(2,00 \% 125)(07084)(.80) \\
& =7.501 \mathrm{~N}^{2} \\
& \text { IMPACT'FORCE } \quad-210,000 \mathrm{LB} \\
& f_{t}=28,000 \text { P.JI NOT CRITICAL }
\end{aligned}
$$

Thread relief

$$
\begin{aligned}
& O . D=2.63 \\
& \text { InD }=2.020 \\
& \text { AREA }=2,201 \mathrm{~N}^{2} \\
& 3 \text { iMPACT FORCE } 210,000 \\
& f_{t}=\frac{210,000}{2.20}=95,145 \\
& \text { IF IMPACT IS REDUCED } \\
& \text { TO } 70,000 \text { LB } \\
& \sum f_{t}=31,715 \text { PS! } \\
& \text { PUL OUT FORCE }=.8(16500)=13200 \\
& f_{t}=6000 \mathrm{PSI} \text { NOTCRITKAL }
\end{aligned}
$$

THREAD CONNECTION TO SHOULDER SUB .(RO919-01)

2.0 INCH - 8-STUB ACME

LENGTH OF THREAD ENGAGEMENT $=1,50$ INCHES

AREA $=4,51 \mathrm{~N}^{2}$

IMPACT FORCE 210,$000 ; f_{t}=46,667$ PS!

MARIN $=1.2$ OVER YIELD FOR NITRONIC 60 ST: STEEL.

82 
BY. DATE

PAGE P 7

CH'KD. DATE $11-16-79$

TI TE

CENTER PISTON ROD DUG BI219

LOWER PISTON ROD DUG R.1232

THE IMPACT FORCE IS REACTED ABOVE THE PISTON ROD CONNECTIONS.

THE CRITICAL LOADING CONDITIONS APPEAR TO BE PENETRATION \& PULL ONT PLUS SNATCH LOADS PENETRATION - COLUMN LOADING FULL FIXITY BOTHEINDS PISTON ROD IN TENSION BY VIRTUE OF SLIDING FRICTION HENCE ALLOW FRICTION COEFFICIENT $=0,2$ PRESSURE MAXIMUM PISTON AREA $\sim$ FORCE $=3000$ PAS. AREA

$\sim 5,51 \mathrm{~N}^{2}$

$\sim 3300 \mathrm{LB}$

ft $=\begin{aligned} & 1.22721 \mathrm{~N}^{2} \\ & 2689 \text { PS! }\end{aligned}$

EXTRATION FORCE USUME $3 \mathrm{~g}$ JERK AT PULL OUT

$$
\begin{aligned}
i f_{t}=\frac{16500 \times .8 \times 3}{1.2272} & =32,268 \mathrm{PS} / . \\
\text { STRESS AT REDUCED SECTION } & =39,560 \mathrm{PSI}
\end{aligned}
$$

THREADED CONNECTIONS R 1232 , A 1218, \& B 1219

THREAD $7 / 8$ NS, COARSE 9 TAI LENGTH 1.12 ( 8THREADS. ENGAGED)

$$
\text { AREA }=0.42 \mathrm{IN}^{2} \quad f_{t}=94,285 \mathrm{P}_{1} \mathrm{~S}_{1}
$$

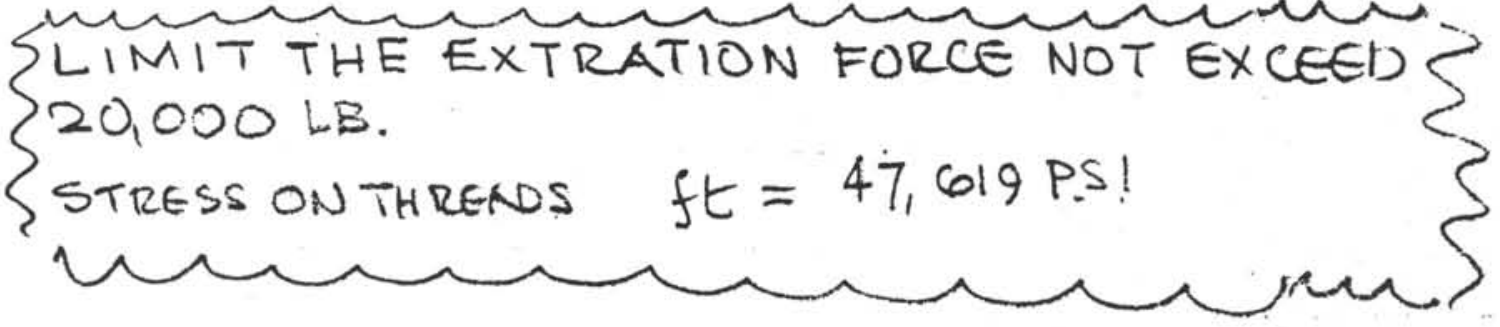

83 


\section{HYDRAULIC PISTON CORER}

\section{RETRIEVAL FORCE ALLEVIATION}

CONTENTS

Problem Staement

Candidate Approaches

Study Matrix

Discussion

Category Grouping.

\section{Topics}

Study Matrix a listing and first order evaluation of proposed approaches for the solution.

Sketches for design concepts。

Description of a cursory test and scaling technique.

Prepared by: Wil Nugeuh

Wilfred Nugent. 


\section{RETRIEVAL FORCE ALLEVIATION}

Problem Statement Hydraulic Piston Coring into increasingly stiffer sediment, produces greater resistance to pull-out. These H.P.C. pull-out forces are approaching the capacity limits of ship-board auxilliary equipment.

The objective of this study is to evaluate methods for the alleviation the holding force of the corer barrel when driven into the sediment.

Candidate Approaches

Cutting shoe profile (shaping)

Fluid flow to the shoe tip \& annulus.

Expendable sheath.

Rotation of the lower barrel.

Vibration \& Jarring of the corer

Retrievable sheath.

Coated lower barrel.

Flexible shoe.

Study Matrix.

The study matrix presents a description, functional analysis, a statement on the available equipment, fabrication factors, test requirements and competitive criteria comparison.

Discussion

Sketches which show the configurations are shown to aid in the selection process of candidate concepts.

There appears to be a possibility of grouping concepts which involve similar design and/or functional approach.

Category Grouping

The shaping of the shoe may be designed to compress or splay the cored hole (sidewall) thus relieving the retention condition. Items No1 \& No 8 may be evaluated on competitive terms. The expendable and retrievable sheath configurations 3 \& 6 and the coated barrel No 7 have similar end approaches.

The Deep Sea Drilling Project has significant advantage over"gravity drop" oceanographic coring tools in that jarring and pull-back can be accomplished by raising the drill pipe. 


\begin{tabular}{|c|c|c|c|c|c|}
\hline$\overline{\text { CONCEPT }}$ & DESCR IPTION & FUNCTION ANALYSIS & FAB. FACTORS & TEST REQMTS & REMARKS \\
\hline $\begin{array}{l}\text { Cutting Shoe } \\
\text { Profile }\end{array}$ & $\begin{array}{l}\text { Shape the external } \\
\text { profile of the } \\
\text { cutting shoe }\end{array}$ & $\begin{array}{l}\text { Hydrodynamic } \\
\text { shaping. } \\
\text { Flow testing of } \\
\text { models }\end{array}$ & $\begin{array}{l}\text { Machine } \\
\text { Test parts }\end{array}$ & $\begin{array}{c}\text { Flow Channel } \\
\text { Stab tests }\end{array}$ & $\begin{array}{l}\text { No operation- } \\
\text { al risk }\end{array}$ \\
\hline $\begin{array}{l}\text { Fluid flow } \\
\text { to shoe \& tip }\end{array}$ & $\begin{array}{l}\text { Cut spiral flutes } \\
\text { Cut flutes axially } \\
\text { along core barrel }\end{array}$ & $\begin{array}{l}\text { Break the side } \\
\text { of the cored } \\
\text { hole. } \\
\text { Neg. Press. in } \\
\text { puli-back draws } \\
\text { in water lub.effect }\end{array}$ & $\begin{array}{l}\text { Machine } 0 . \mathrm{D} \text {. } \\
\text { of barrel }\end{array}$ & $\begin{array}{l}\text { Test in } \\
\text { operation }\end{array}$ & $\begin{array}{l}\text { Notches the } \\
\text { barrel }\end{array}$ \\
\hline $\begin{array}{l}\text { Expendable } \\
\text { Sheath }\end{array}$ & $\begin{array}{l}\text { On 0.D. of Barrel } \\
\text { Instal a sliding } \\
\text { element }\end{array}$ & $\begin{array}{l}\text { Provide initial } \\
\text { sliding at start } \\
\text { of pull-out }\end{array}$ & No impact & $\begin{array}{l}\text { Test in op- } \\
\text { ation } \\
\text { Stab tests }\end{array}$ & $\begin{array}{l}\text { Left in core } \\
\text { hole could } \\
\text { cause problem }\end{array}$ \\
\hline $\begin{array}{l}\text { Rotation of } \\
\text { Lower barrel }\end{array}$ & $\begin{array}{l}\text { Unlock a thread } \\
\text { connection \& } \\
\text { allow the barrel } \\
\text { to rotate }\end{array}$ & $\begin{array}{l}\text { Rotate the barrel } \\
\text { to break the } \\
\text { side hole bond }\end{array}$ & $\begin{array}{l}\text { New design } \\
\text { to unlock } \\
\text { the cutting } \\
\text { shoe in pull } \\
\text { out }\end{array}$ & $\begin{array}{l}\text { Model test } \\
\& \text { shore test } \\
\text { in sediment }\end{array}$ & $\begin{array}{l}\text { Core barrel } \\
\text { must not rotate } \\
\text { around core } \\
\text { Destoy alignmt. } \\
\text { or twist core }\end{array}$ \\
\hline $\begin{array}{l}\text { Vibration \& } \\
\text { Jarring }\end{array}$ & $\begin{array}{l}\text { Use drill deck } \\
\text { equipment }\end{array}$ & & & & $\begin{array}{l}\text { Limit force } \\
\text { on drill string }\end{array}$ \\
\hline $\begin{array}{l}\text { Coated lower } \\
\text { barrel }\end{array}$ & $\begin{array}{l}\text { Hard smooth } \\
\text { surface on lower } \\
\text { barrel }\end{array}$ & $\begin{array}{l}\text { Provide an } \\
\text { inpenetrate- } \\
\text { able surface on } \\
\text { the barrel }\end{array}$ & $\begin{array}{l}\text { Electroplate } \\
\text { Flame sp ay }\end{array}$ & $\begin{array}{l}\text { Test in oper- } \\
\text { ation }\end{array}$ & $\begin{array}{l}\text { No risk } \\
\text { involved. }\end{array}$ \\
\hline $\begin{array}{l}\text { Corer barrel } \\
\text { O.D. config- } \\
\text { urations }\end{array}$ & $\begin{array}{l}\text { Refer to } \\
\text { sketches } \\
8,9,810\end{array}$ & $\begin{array}{l}\text { Enlarge core hole } \\
\text { during penetration } \\
\text { relax during }\end{array}$ & $\begin{array}{r}\text { New shoe } \\
\text { Design }\end{array}$ & $\begin{array}{l}\text { Stab test } \\
\text { Test in oper- } \\
\text { ation }\end{array}$ & $\begin{array}{l}\text { No risk } \\
\text { involved. }\end{array}$ \\
\hline
\end{tabular}




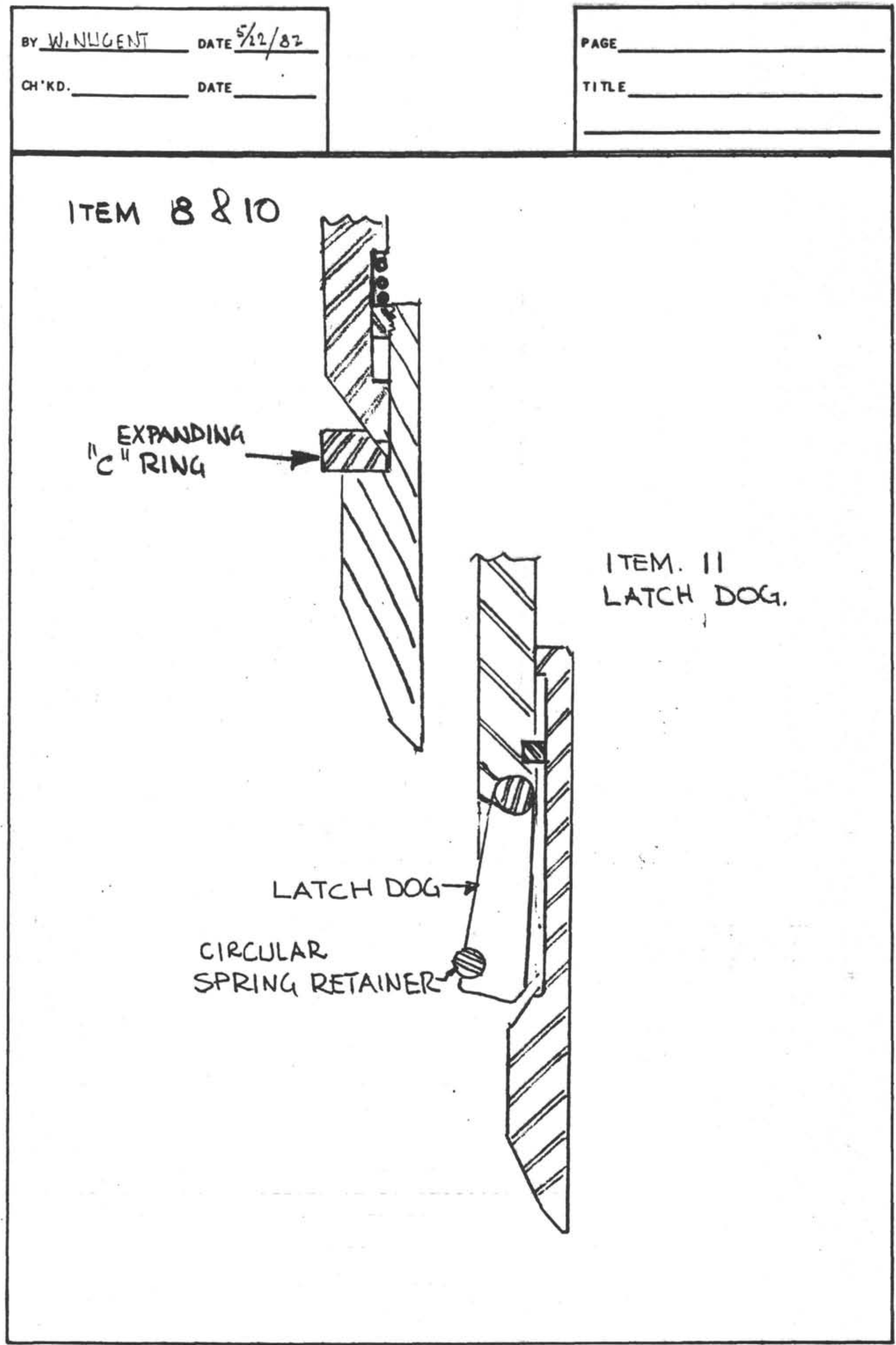




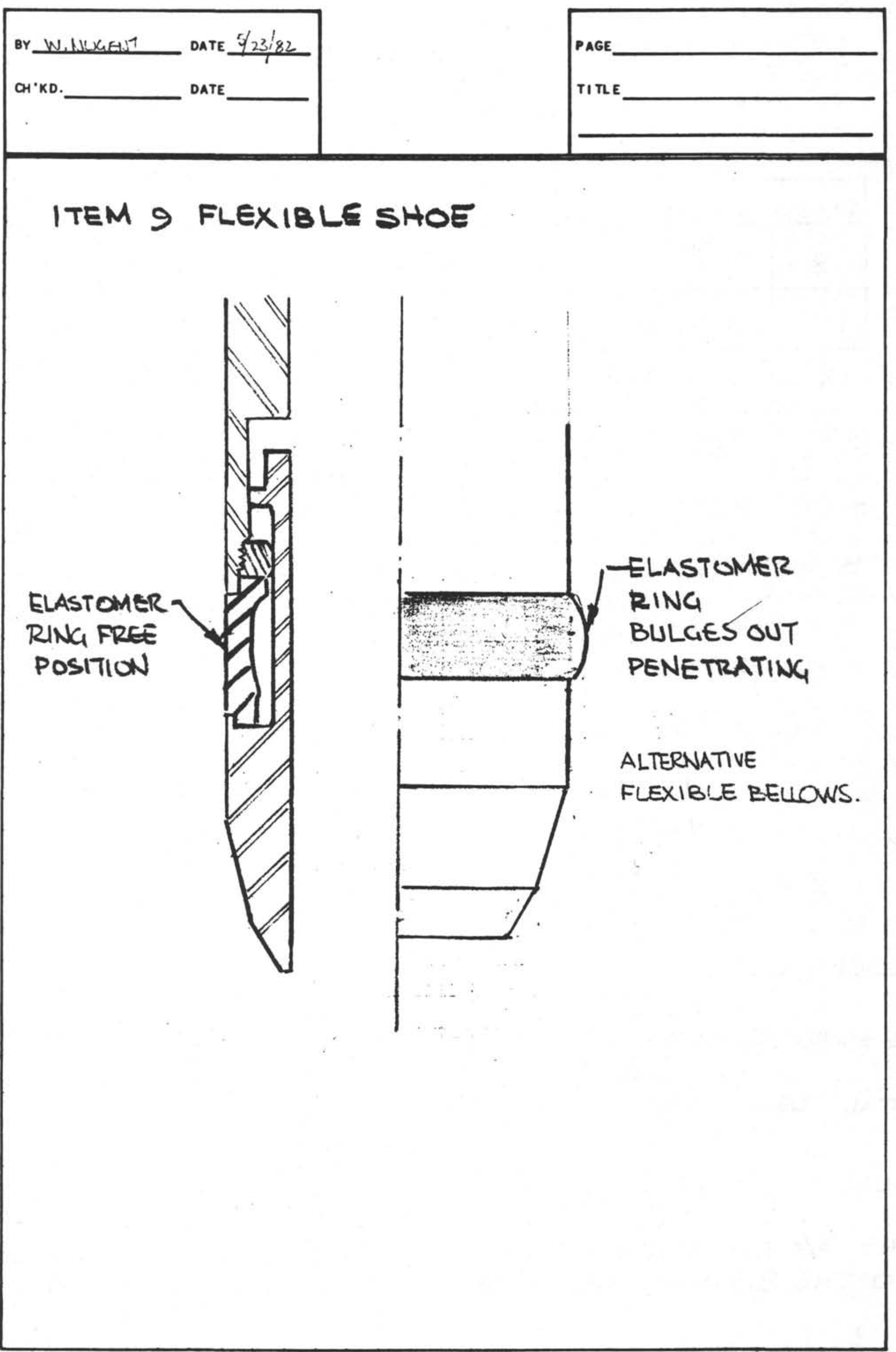


scale test

A CUR'BOKY TEST. WAS RUN to quALITATIVELY OBSERVE THE ETFULIS OE PULL BACK FORCE ON FOUR SECTIONS OF TIES, DRIVEN INTO SATURATED GARDEN CLAY, the results are tabulated. As. Follow'!

\begin{tabular}{|l|l|c|c|c|c|}
\hline DIAINS CIRCUMF & \multicolumn{2}{|c|}{ FORCE INCH LENGTH } & \multicolumn{2}{c|}{ FORCE ${ }^{12}$ INCHLENGTH } \\
\hline LOAD IN \\
\hline $3 / 8$ & 1.178 & 6 & .85 & 12.5 & .884 \\
\hline 1. & 3.1416 & 13 & .69 & 25 & .663 \\
\hline $1 / 4$ & 3.927 & 15.5 & .637 & 33 & .70 \\
\hline $13 / 4$ & 5.977 & 18 & .5019 & - & - \\
\hline
\end{tabular}

THE (FORCE) LOAD PER INCH APPEARS TO DECREASE WITH INCREASE IN DIAMETER. HOWEVER IT SHOULD BE NOTICED THAT THE LID RATIO IS 32 FOR A 12 INCH LENGTH OF $3 / 8$ DIN TUBE WHEREAS THE LID REDUCES TO 9.6 FOR A $121 \mathrm{NCH}$ LENGTH OF $1 / 4$ DI TUBE.

APPLYING FROUDE SCALING FACTORS $l=$ LENGTH

$$
\begin{aligned}
& F_{m}=V_{m}^{2} / L_{m} g \quad N^{2}=A R E A \\
& F_{F}=\frac{V_{F}^{2} / L_{m g}}{F_{F}}>\frac{F_{M}}{F_{F}}=\frac{V_{m}^{2} L_{F} g}{V_{F}^{2} L_{m} g}, l^{3}=\text { FORCE } \\
& \begin{aligned}
\frac{V \text { model }}{\sqrt{\text { model }}} & =\frac{V_{\text {Fol scale }}}{\sqrt{\text { LFullscale } g^{\prime}}} \\
V_{\text {mold }} & =\sqrt{\frac{L_{m}}{L_{F}}}\left(V_{F}\right)
\end{aligned}
\end{aligned}
$$

VELOCITY SCALING
PRESTON PRESE SCALING $=\sqrt{\frac{1}{\gamma}}\left(V_{\text {PUL SCALE }}\right)$

PRESSURE SCALING
P model

TOTAL FORCE $W=\frac{1 / 2 P V^{2} S f \quad \text { AREA }}{2}=\left(\frac{1}{\gamma}\right)^{2}$

THEN $\quad W_{\text {Model }}=\left(\frac{1}{\gamma}\right)^{3} W_{\text {FOU SCALE. }}$

PRESSURE $=\left(\frac{1}{\gamma}\right)$

THE $3 / 3$ DI $\times 12$ INCH TUBE MORE CLOSELY CONFORMS TO THE $3.5 \mathrm{INCH} \times 180 \mathrm{INCH}$ CORER BARREL, \& WILL

90 
bE REVIEWED for COMPARISION USING FROUDE

7 SCALING TECHNIQUES.

3/8 DIA T.JBE

SCALE FACTOR $l=9.334$

force varies as the cube of the scale factor

$F_{\text {Full scale }}=F_{\text {Model }} l^{3}$

$$
=12.5(9.334)^{3}=10,165 \mathrm{LB}
$$

THIS COMPARISON NEGLLCTS THE LENGTH FACTOR 180/12 $=15$. TO COMPENSATE For THIS DIFFERENCE USE THE RATIO of circumference 9,334 AND. THE area scaling factor $l^{2}$, AND THE PULL BACK FORCE PER INCH,

FOR THE 3/3 DIA $\times 12$ INCH TUBE USE, 884 LB/ INCH

THEN

$$
\begin{aligned}
F_{\text {Fuluscale }} & =F_{\text {model }} l^{2} \\
& =.884(9.334)^{2}=77 \mathrm{LB} / \mathrm{INCH}
\end{aligned}
$$

FOR 15 FEET LENGTH OF 3.5 INCH DA CORER BARREL

THE PROBABLE PULL BACK FORCE $=13,863, \mathrm{LB}$.

THERE IS A HIGH PROBABILITY THAT THE PULL BACK FORCE INCREASES EXPONENTIALLY WITH THE DEPTH OF CORER PENETRATION.

91 


\section{HYDRAULIC PISTON CORER}

LANDING IMPACT

CONTENTS

Problem Statement

WorkDone

Discussion

Conclusions

Topics

A H.P.C. instrumented core barrel was to be landed onto a suuport bearing within the Drill String to a depth of 20,000 feet.

Terminal velocity estimates with varying hydrodynamic drag values An evaluation of the impact on the instrument package.

Transmissibility of shock.

Testing of the shock mitigation device.

Prepared by: lial oreugouk

Wilfred Nugent. 
i.r.S.T.Serocki. Chief Engineer

Deep Sea Drilling Froject.

university of California at San Diego.

La Jolla, California

\section{W. NUGENT}

Reo. Pronessional Eno.neEs

Asscciate faLLOW AIAA

Subject: Impact of the Core Barrel on the Support Bearing Nount.

1.0 Problem Statement.

During coring operation an instrumented core barrel is allowed to fall within the drill pipe at its terminal velocity, estimated to be 500 feet per minute.

The purpose of this analysis is to define the impact acceleration and make a prepction as to the shape of the curve.

2.0 Work Done.

A check on the range of the terminal velocity was made, with variation in hydrodynamic drag coefficient.

An estimate of the spring rate for the elements and the characteristics at the impact face was made and used in the solution of a spring

mass system.

Damping factors were developed and used intuitivezy

Five Cases were examined as follows:

I.Free fall of the mass at $10 \mathrm{ft} / \mathrm{sec}$. no damping.

II" " $18 \mathrm{ft} / \mathrm{sec}$. light damping

III " " $10 \mathrm{ft} / \mathrm{sec}$. more heavily damped

IV same as III, but with reduced damping coefficient \& spring rate.

$\mathrm{V}$ same as IV, dut with reduced damping coefficient.

An additional analysis evaluates the effect of the impact on the

instrument package installed within the core barrel.

3.0 Conclusions.

The conclusions drawn from the work done are:

1) Case I an undamped system does not occur in reality, but serves to indicate the maximum impact condition for the selected case.

2) Case II was developed to examine the effects of increased descent velocity ( $18 \mathrm{ft} / \mathrm{sec}$.

3) Cases III, IV, and V, vary mainly by the degree of damping coefficient applied.

4) Case II presents the most severe condition.

5) The instrument package can be protected against exposure to high positive or negative acceleration if the mounting has a

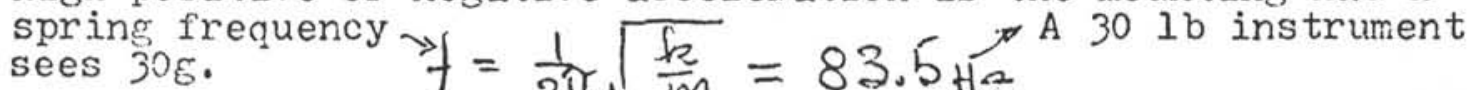

$$
f=\frac{1}{2 \pi} \sqrt{\frac{k}{m}}=83.5 \mathrm{H}=
$$

The data fenerated is plotted for Cases I, II, III, IV, \& V.

The plotted data shows the Change in Velocity versus Time and enables the acceleration to be derived as a tangent to points on the curve. 
VALUES FOR C AND K.

THE CORE BARREL PACKAGE FALLS AT A TERMINAL VELOCITY ATTAINED WHEN THE STATE O EQUILIBRIUM. IS REACHED BETWEEN THE TOTAL DRAG FORCE ACTING (FRONTAL \& SURFACE FRICTNN) AND THE WEIGHT. THEN $W=D$.

IN A FLUID MEDIUM DIRAC IS EXPRESSED AS $1 / 2 \rho C_{D S} V^{2}$

THEN

$$
\begin{aligned}
& W=1 / 2 \rho_{C D} S V^{2} \\
& V=\left(\frac{W}{1 / 2 \rho C_{D} S}\right)^{1 / 2}
\end{aligned}
$$$$
\text { AND }
$$

FrOM THE GEOMETRY OF THE CORE BARREL A CD OF 2 IS USED THE MASS DENSITY OF SEA WATER 22 FRONTAL AREA

$$
\sum_{12} 1 N^{2}=1 / 12 F T^{2}
$$

$$
\left(\frac{360 \times 12}{2}\right)^{1 / 2}=46.47 \mathrm{FT} / \mathrm{seC}
$$

THE VALUE FOR DRAG COEFFICIENT FOR A LONG, SLENDER BODY MOVING WITHIN A CYLINDER IS SIGNIFICANTLY MICHEL THAN THE MARETERISIIC CASE OF 2.0 THEREFORE CONSIDER AN INCREASE BY ORDER OF MAGNITUE, AND WE GET $14,7 \mathrm{FT} / \mathrm{SEC}$ SPECIFIED VELOCITY IS $500 \mathrm{FT} / \mathrm{MIN}$. USE $10 \mathrm{FT} / \mathrm{SEC}$

DAMPING CONSTANT ZERO TO ESTABLSH MAXIMUM IMPACT

SPRING RATE

WISING 180,000 PSI BEARING STRESS AND.80 OF THE ANNULUS AREA OE THE IMPACT STOP. $22,641 \mathrm{H}^{2}$

ASSUME THE COLUMN DEFLECTS 0.12 (BOWING I DURING IMPACT)

DEFLECTION OF CONTACT 0.005

BEARING DEFLECTION 0.005

TOTAL. DEFLECTION O. 13 inCHES

ALLOWABLE SURFACE LOAD $=180,000 \times 2.64=475,2001 \mathrm{~b}$.

SPRING RATE LE/FT = 47,520,000

THE PLOT OF THESE DATA POINTS WILL INDICATE A CONTINIAINA CYCLE WHICH IN REALITY DOES NOT OCCUR.

95 


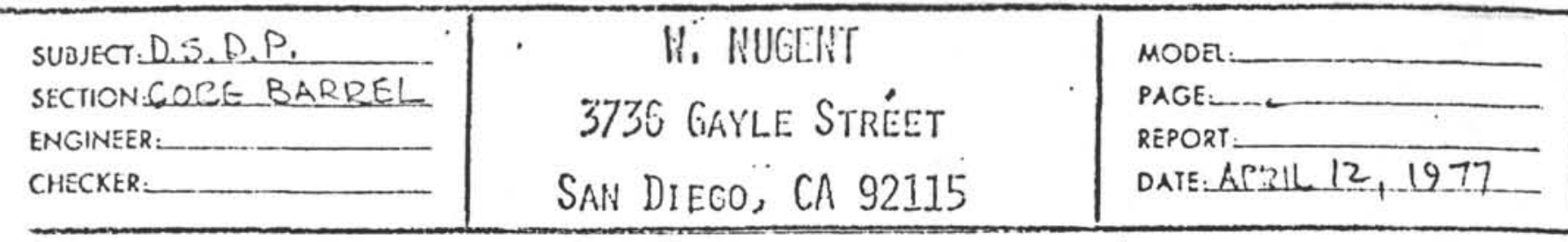

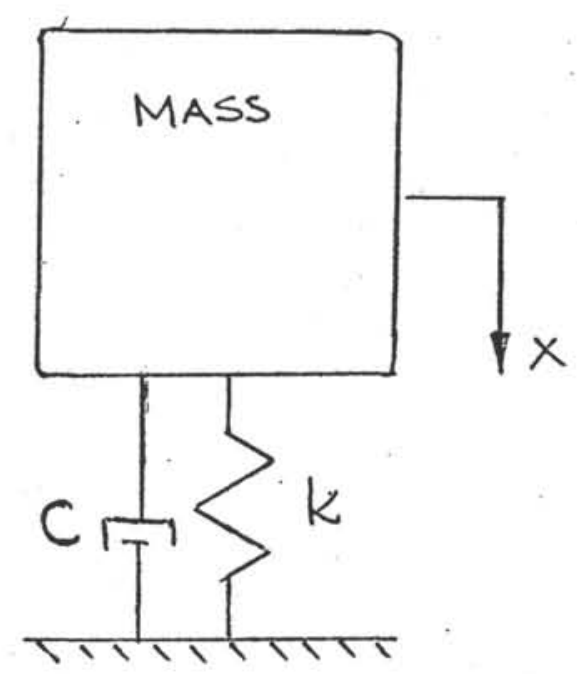

WRITING THE EQUATION OF MOTION IN TERMS OF THE DISPLACEMENT $X$ A DAMPING CONSTANT $C$ AND A SPRING RATE $K^{\prime}$, THE FollOWING EQUATION' IS DEVELOPED

$$
c \dot{x}+k x=-m \ddot{x}
$$

OR $\frac{d^{2} x}{d t^{2}}+\frac{\varepsilon}{m} \frac{d x}{d t}+\frac{k}{m} x=0 \quad E Q U(1)$

LET $C / m=2 a$ AND $K / m=b^{2}$

THEN EQU(1) CAN BE WRITTEN AS $\frac{d^{2} x}{d t^{2}}+2 a \frac{d x}{d t}+b^{2} x$

SOLVING THE quaDRATIC USING $A_{e}^{\alpha t}$

$$
\begin{aligned}
& \alpha^{2}+2 a+b^{2}=0 \\
& \alpha+a= \pm \sqrt{a^{2}-b^{2}} \\
& \alpha_{1}=-a-\sqrt{a^{2}-b^{2}} \\
& \alpha_{2}=-a+\sqrt{a^{2}-b^{2}}
\end{aligned}
$$

THEN $x=A e^{\alpha_{1} t}+B e^{\alpha_{2} t}$ IS THE COMPLETE SOWUINI

96 
NUMELLCAC. ANALYST CASE $N^{2} 1$

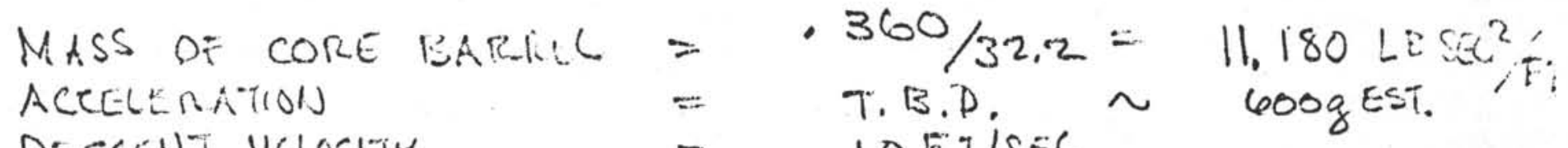

DESCENT VELOCITY SPRING RALE

DAMPING CONSTANT

$$
\begin{aligned}
& =10 \mathrm{FT} / \mathrm{SEC} \\
& =47.5 \times 10^{\circ} \mathrm{b} / \mathrm{FT} .
\end{aligned}
$$

FROM PACE (I)

$$
=0
$$

LET $b=2000$ for numerical analysis

$$
\begin{aligned}
\alpha & =-a \pm \sqrt{a^{2}-b^{2}} & \text { WHEN } a & =0 \\
& := \pm 2000 i & b^{2} & =4,000,000 \\
\alpha & = \pm & &
\end{aligned}
$$

THEN

$$
\begin{aligned}
x & =A e^{(2000 i) t}+B e^{(-2000 i) t} \\
& =e^{t}\left(A e^{2000 i}+B e^{-2000 i}\right) .
\end{aligned}
$$

AND WHEN COD ARE CONSTANTS DEPENDING ON THE INITIAL CONDITIONS, $x=e^{t}(C \cos 2000 t+D \sin 2000 t)$

$$
\begin{aligned}
\frac{d x}{d t}= & e^{t}(C \cos 2000 t+D \sin 2000 t) \\
& +e^{t}(-2000 C \sin 2000 t+2000 D \cos 2000 t)
\end{aligned}
$$

FOR THE INITIAL CONDITIONS $x=0, v=10$, \& $t=0$

WHEN $t=0, x=0$. THEN $C=0$

WHEN $E=0, V=10$. THEN $D=, 005$

PUT THESE VALUES IN $x=e^{t}(c \cos 2000 t+D \sin 2000 t)$

$$
\begin{aligned}
= & e^{t}(.005 \sin 2000 t) \\
\frac{d x}{d t}= & e^{t}(.005 \sin 2000 t+10 \cos 2000 t) \\
\frac{d^{2} x}{d t^{2}}= & e^{t}(.005 \sin 2000 t+10 \cos 2000 t) \\
& +e^{t}(10 \cos 2000 t-20000 \sin 2000 t)
\end{aligned}
$$


$30-250-1 \quad(9-51)$

$\infty$

VELOCITY VS TIME

CONDITIONS:

CORE BARZEL
DEECENTVELOCITY $\approx$ 3GOLES
1OFT/SEC

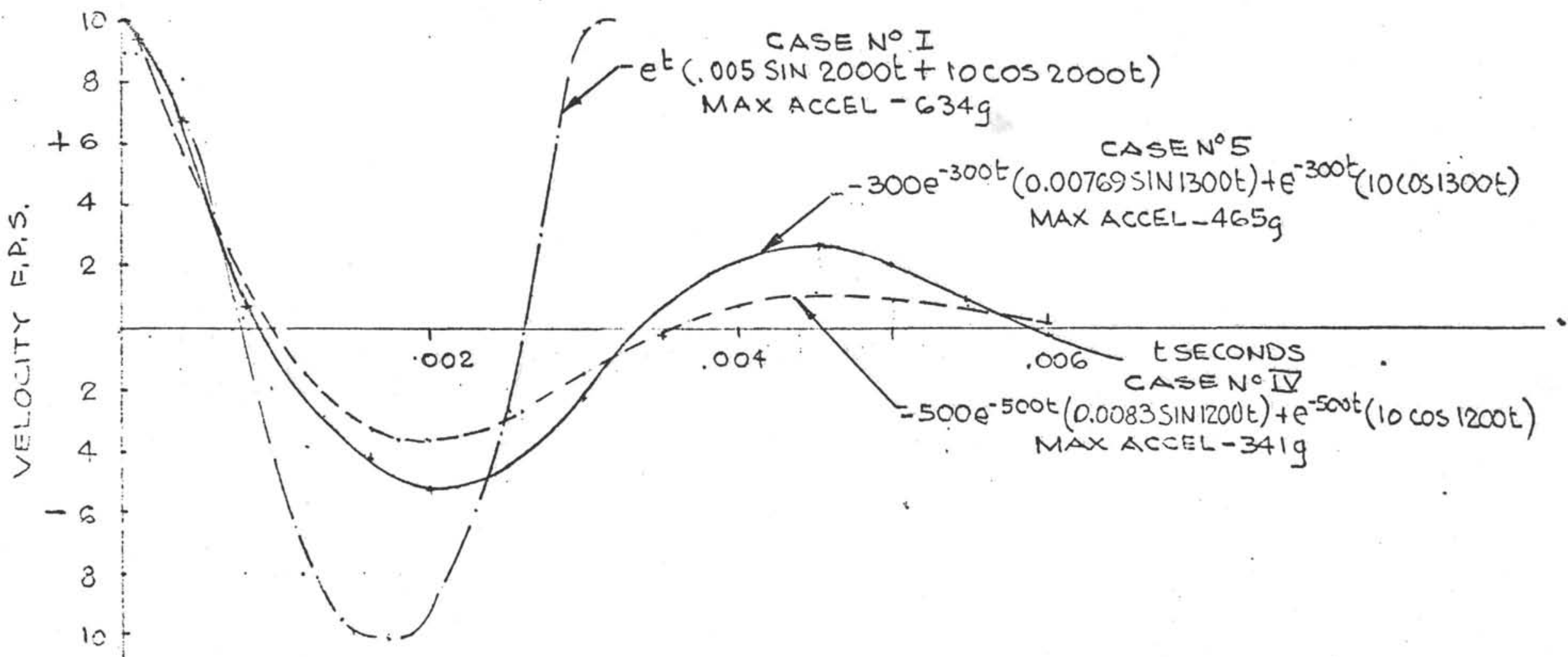

127

FICIUREI WN 4.22 


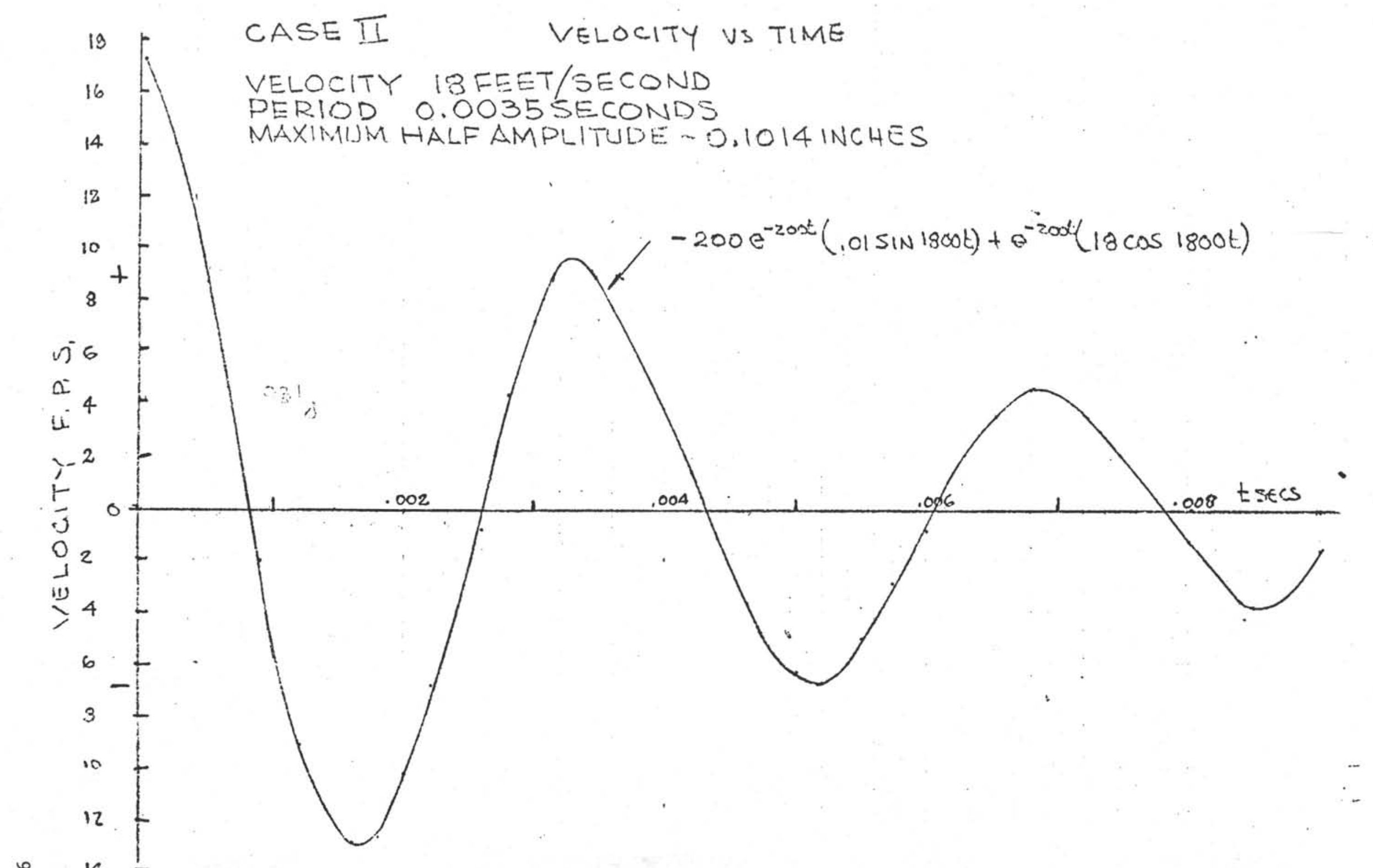




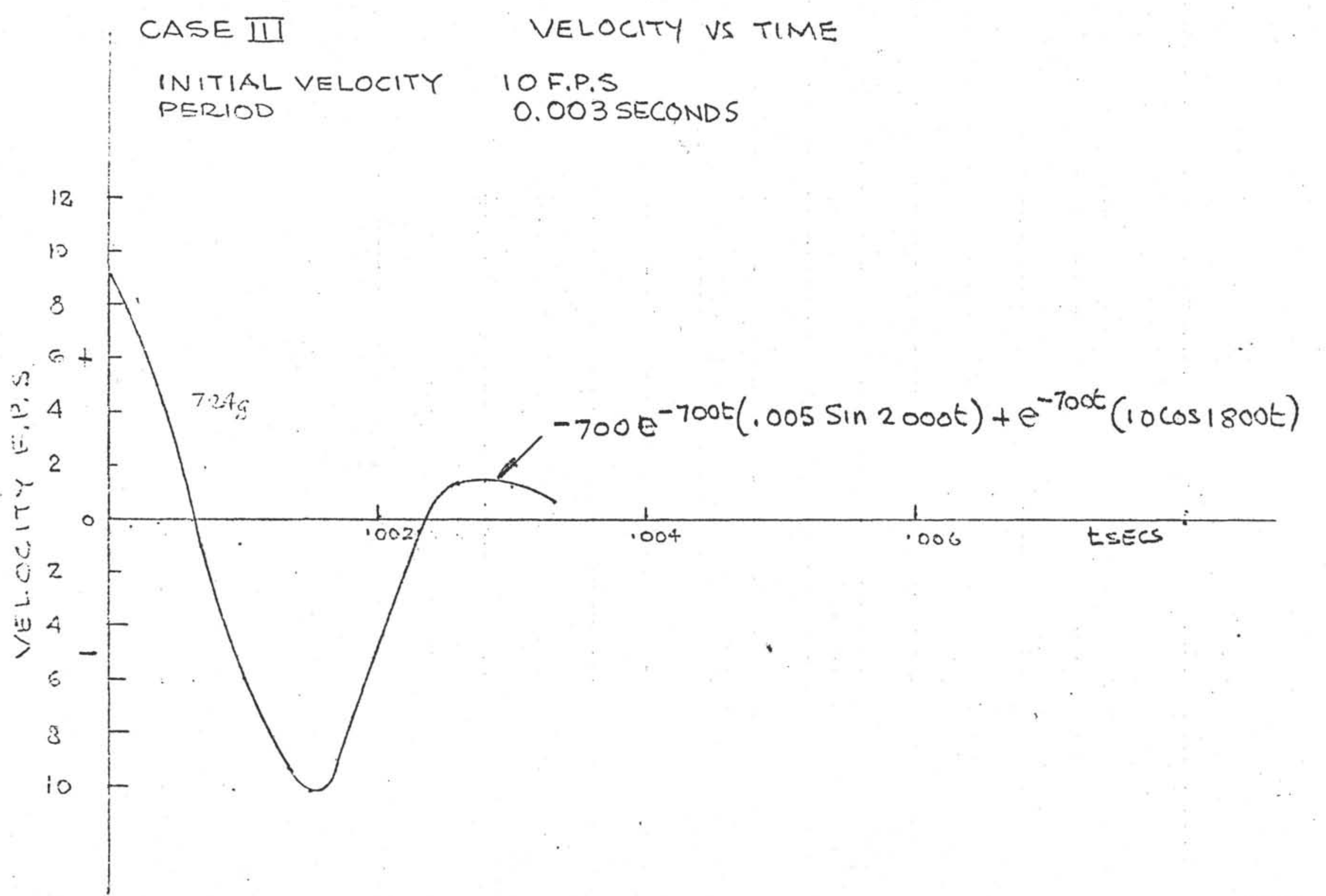


APQ1L 19.1977

MEETING WITH MR ST. SEROCK.1.

MR BURT ADAMS

MR MLMAELSTORHS

SUBJECT' CORE BARREL: DROP TEST

1. DATA PRESENTed ROUGH DRAFT OF REPORT DSDPH.2 general conclusion of meeting FORCE OF IMPACT $\sim 335,000 \mathrm{LB}$ THEORETIC CIS ' TRANSMITTED CIS $\sim 900 \mathrm{~g}$
T $90 \mathrm{~g}$.

2. CORRECTION TO ESTIMATE FOR DETERMINING SPRING CONSTMTI limit the allowance stress at the face' of the LANDING SUB \& THE BEARING BLOCK TO 120,000 PSI THIS PRODUCES $(120,000 \times 1,35) 162,000$ LB END FORCE THE END FORCE $360(400 \mathrm{~g}) / 1.35=106,666 \mathrm{PSI}$.

CASE IV

MASS OF CORE BARREL ACCELERATION DESCENT VELOCITY SPUING RATE \&, DAMPING CONSTANT RE OF BARREL $=1 / 2 M V^{2}$

$$
\begin{aligned}
& =11.18 \text { LOSEL } 2 / F \\
& =10 \mathrm{FT} / \mathrm{SEC} \\
& =18.84 \times 10^{\circ} \mathrm{LB} / \mathrm{FT} \\
& =11952 \mathrm{LB} \cdot S \mathrm{SE} / \mathrm{F} \\
& =560 \mathrm{FT} \mathrm{LB} .
\end{aligned}
$$

DISPLACED VOLUME IN LOWER CHAMBER $3.5 \pi$

PULSE PRESSURE IN COWER CHAMBER $\eta^{+}$ ANNULUS AREA

LENGTH OF THE LOWER CHAMBER

FLOW VELOCIYYTHCOUEA TEE CONSTRICTOr

$$
\begin{aligned}
(6) /(1728) & =0.033 F^{3} \\
& =16,733 \text { PSF. } \\
& =0.001 \mathrm{FT}^{3} \\
& =0.5: T_{T} \\
& =242 \mathrm{FT} / \mathrm{S}=\mathrm{C}
\end{aligned}
$$

FLOW THROUGH CONCENTRIC CYLINDERS $Q=\frac{d(c)^{2} P}{l v 3} \times 1.3 \times 10^{2} \mathrm{FT} / \mathrm{sEC}$

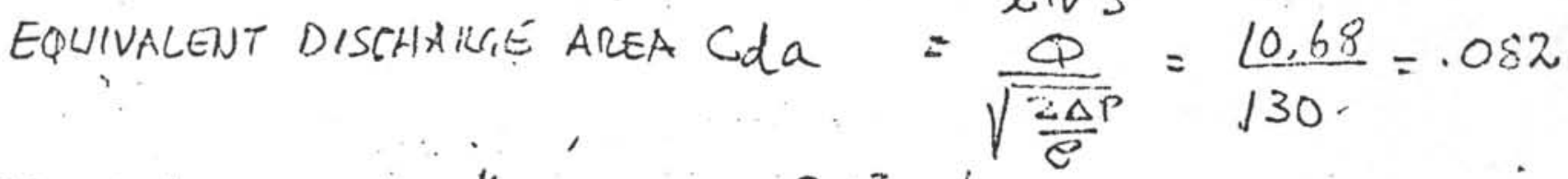

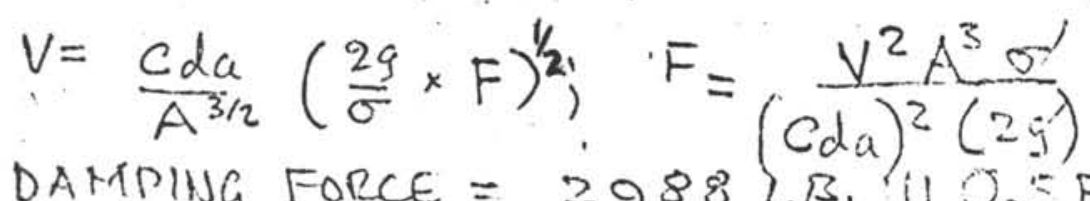

DAMPING FORCE $=2988 \mathrm{LB}$. WI O.SFT IN. OS SECOND

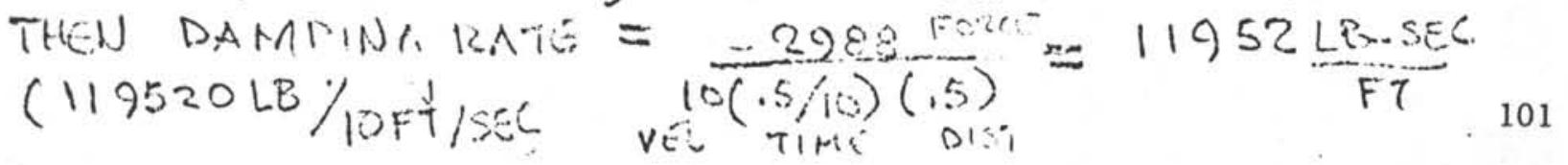


numerical analysis case iv

$$
\begin{aligned}
x & =A e^{\alpha_{1} t}+B e^{\alpha_{2} t} . \\
c / m & =2 a=1069 ; \text { te rpm }=b^{2}=16.85 \times 10^{5} \\
\text { Let } a & =500 \\
\alpha & =-a \pm \sqrt{a^{2}-b^{2}} . \\
& =-500 \pm 1198.87 i
\end{aligned}
$$

THEN

$$
\begin{aligned}
x & =A e^{(-500+1200 i) t}+B e^{(-500-1200 i) t} \\
& =e^{-500 t}\left(A e^{1200 i}+B e^{-1200 i}\right) \\
& =e^{-500 t}(C \cos 1200 t+D \sin 1200 t)
\end{aligned}
$$

$$
V=\frac{d x}{d t}=-500 e^{-500 t}(C \cos 1200 t+D \sin 1200 t)
$$

$+e^{-500 t}(-1200 c \sin 1200 t+1200 D \cos 1200 t)$

INITIAL CONDITIONS:

$$
x=0, \quad v=10, \quad t=0
$$

WHEN $t=0, x=0$, AND $c=0$

WHEN $t=6, V=10$ THEN $D=.0833$

$$
\begin{aligned}
x= & e^{-500 t}(-00833 \sin 1200 t) \\
\frac{d x}{d t}= & -500 e^{-500 t}(.00833 \sin 1200 t)+e^{-500 t}(10 \cos 1200 t) \\
\frac{d^{2} x}{d t^{2}}= & 25 \times 10^{4} e^{-500 t}(.00833 \sin 1200 t)-500 e^{-500 t}(10 \cos 1200 t) \\
& -500 e^{-500 t}(10 \cos 1200 t)+e^{-500 t}(-12000 \sin 1200 t)
\end{aligned}
$$

PERIOD

$$
\begin{aligned}
\tau & =2 \pi \sqrt{\frac{m}{\sqrt{2}}} \\
& =5.22 \times 10^{-3} \text { SECONDS }
\end{aligned}
$$

102 
CORE BARREL ASSEMBLY IMPACT CONDITION

A PREVIOUS DROP TEST OF A CYLINDRICAL SHAPED BODY WITH A POINTED SPIKE ON A FLAT STEEL PLATE PRODUCE A $700 \mathrm{~g}$ ( 0.4 MILLISECOND) HALF SINE WAVE PULSE THE SHOCK RESPONSE OF A SPRING MAAS SYSTEM WAS CALCULATED BY THE FOLLOWING PROCEDURE $f=\frac{1}{2} \pi \sqrt{\frac{l_{c}}{m}}$ NAT FRET

THE ET LATIN OF. MOTION IS $=Q u(1) \quad m\left[\ddot{d_{x}}+\ddot{v}(t)\right]-k_{2} d t=0$

Where $S_{x}$ is the relative acc $=(\ddot{x}-\ddot{v})$

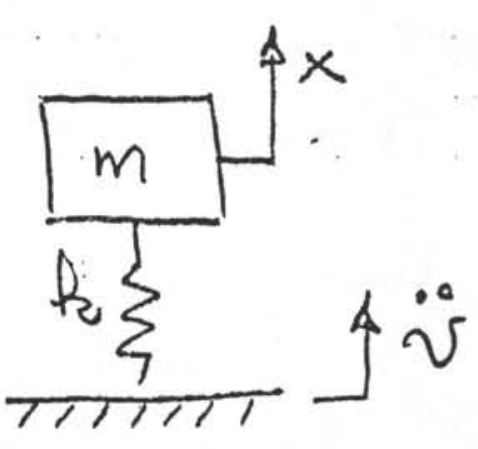

$$
\begin{aligned}
\text { iv IS THE INPUT ACC } & =\ddot{v}_{\max } \sin \frac{\pi}{E} \text { when } 0 \leq t \leq \tau \\
& =0 \text { when } J \leq t
\end{aligned}
$$

IS TIE ACCELERATION PULSE WIDTH IN SECONDS THE SOLUTION OF EQU(I) IS:

Eq (2) $\partial_{x}=\xi_{p} \frac{1}{1-T^{2} / 4 \tau^{2}}\left(\operatorname{Sin} \frac{\pi t}{\zeta}-\frac{I}{2 J} \sin \omega_{n} t\right)[0 \leq t \leq \tau$

EQV (3) $d_{x}=\xi_{P} \frac{(T / T \cos (\pi T / T)}{\left(T^{2} / 4 \tau^{2}\right)-1} \sin \omega(t-T / 2)[\tau \leq t$ Where $\xi$ is The static deFlection of the Mass
assuming a STEAdY LOAD

$\delta_{x}$ is MAXIMOM WHEN $t>T$

$T$ is $\frac{1}{f_{n}}$

ASSUMPTION. LET THE INSTRUMENT PACKAGE WEIGH ES LE.

AND THE POTTINT COIMPONI HAVE A COIAPRESSIUE Y'IELD = 3,000 $\mathrm{p}$ il THE SUPDRT AREA = ISP INCH AND TIE TOM DEFLECTION BE .O FINCHES FOR. THE PLIED STRIKE LOAD OF 3000 LE $f=\frac{1}{2 \pi \sqrt{2.63}} \sqrt{\frac{72 \times 10^{4}}{2.2}}=83,2 \mathrm{t}$

103 
IF the core BARREL AND THE BOTTOM DRILL COLIA"/SI ARE CONSIDERED AS A SPRING MASS SYSTEM I CASE III

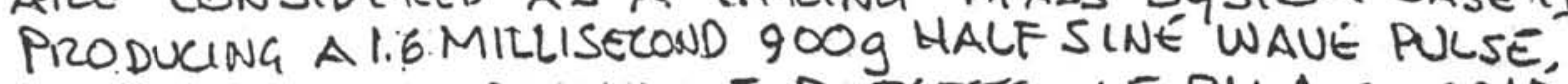
THE INSTRUMENt, RECEPTACLE DEFLECTS 105 BY A $6000 \mathrm{LIS}$ STATIC LOAD $6000 / 80=75$ GRAVITIES

$$
\begin{aligned}
& f=83.2 \text { Hz } \quad T=.0130 \% \text { SECONDS } \\
& T=.0016 \text { MILLISECOND, } T / T=8.15
\end{aligned}
$$

$$
\begin{aligned}
\omega_{n} & =\frac{2 \pi}{T} \\
& =\sqrt{\frac{l_{2}}{m}} \therefore \text { NATURAl FREQUENCY RADS/SEC }
\end{aligned}
$$

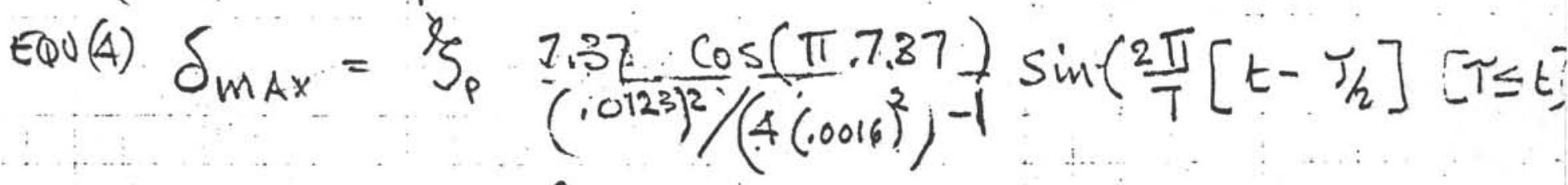

$$
=.03463 \xi_{p}
$$

LOOK. FOR MAXIMUM PRODUCED EU FUNCTIONS OF $t$ $\sin \left(\frac{2 \pi}{T}\left[t-\frac{J}{2}\right] \quad\right.$ LET THIS $=1 \ldots$ if

THEN $\sin (\pi / 2)$ IS PROBABLY A MAXIMUM $\frac{2 \pi}{7}\left[t-\frac{\pi}{2}\right]=\frac{\pi}{2}$

AND $t=\frac{\pi}{2}\left(\frac{I}{2 \pi}\right)+\frac{\tau}{2}$

$$
\sin \pi=\sin \left(\frac{2 \pi}{T}\left[t-\frac{T}{2}\right]\right.
$$$$
t=.00391
$$

$$
\begin{aligned}
t=\frac{T}{4}+\frac{1}{2} \quad 00326 \\
0008
\end{aligned}
$$

$31.16<\quad .03463(000)$

$31.16<35.29$

104 
W. Nugent 10.1279

1. FRGQUAOF CQUMN AT IMPACT

$$
f=\frac{1}{2 \pi} \sqrt{\frac{\hbar z}{m}}=\frac{1}{2 \pi} \sqrt{\frac{19 \times 10^{6}}{11.18}}=207 \mathrm{~Hz}
$$

ESTIMATE $\longrightarrow$ RANGE $\sim 200$ TO $400 \mathrm{HZ}$

2. TRANSUERSE BENDING FREE EREE BEANA

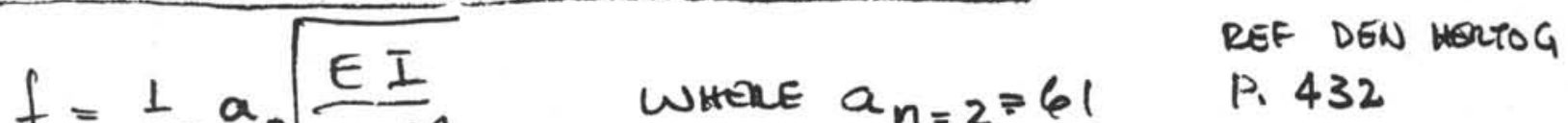

$$
\begin{aligned}
& a_{n}=3=131 \\
& Z_{N D} \text { MODE }=\frac{61}{2 \pi}(1.6476)=16 \mathrm{~Hz} \quad \begin{array}{l}
a_{n}=5=298.2 \\
M=\omega / g l=2.588 \times 10^{-3}
\end{array} \\
& 3 \text { HOOE }=\frac{131}{2 \pi}(1.6476)=34 \mathrm{~Hz} \\
& l=360 \text { wentes } \\
& \omega=360 \\
& 5 \text { THMODE }=\frac{298.2}{2 \pi}(1.6476)=78 \mathrm{HZ} \\
& g=386.4 \mathrm{in} / \mathrm{sec}^{2}
\end{aligned}
$$

3. ANALYSIS LISING ANALOGY OF A WA TER COLUMN IN A CLOSGD PIPE REFERONCE MELASNICA VIBRATION DEN HERTOG. P. 431

$$
f=(1+2 n) \frac{14,200}{l}
$$

$\begin{array}{ll}\text { ZND MODE } & \sim \\ \text { 3RD MODE } & \sim \\ 200 \mathrm{~Hz} \\ 276 \mathrm{HZ} \\ 434 \mathrm{HZ}\end{array}$

4. IMPACT CONDITIONS

$K^{\prime} E=560 \mathrm{FT}$ LB; DEFECTION AT CONTACT $\sim .01 F T$

ESTIMATE AREA UNDER CURUE = KE

$$
\begin{aligned}
\text { THEN FORLE } & =2(560 / .01)=112,000 \mathrm{LB} \\
\text { ACCLERATION g'S } & =112000 / 360=311 \mathrm{~g}
\end{aligned}
$$

5. TRANSMISIRILITY

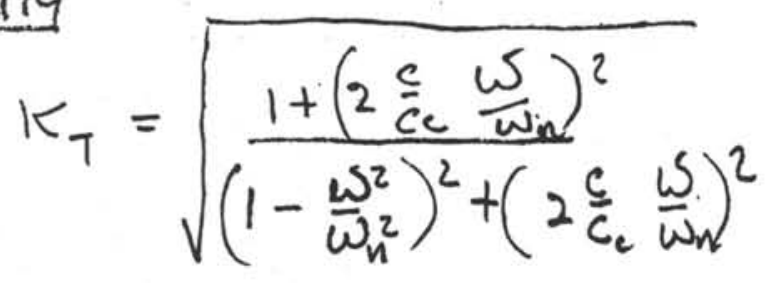

105 
W. Nugent 10,12,79

FrOM THE tranSMISSIBILITY EXPRESSION IT IS SEEN THAT THE TRANS MISSIBILTY IS INFINITE AT reSONANCE

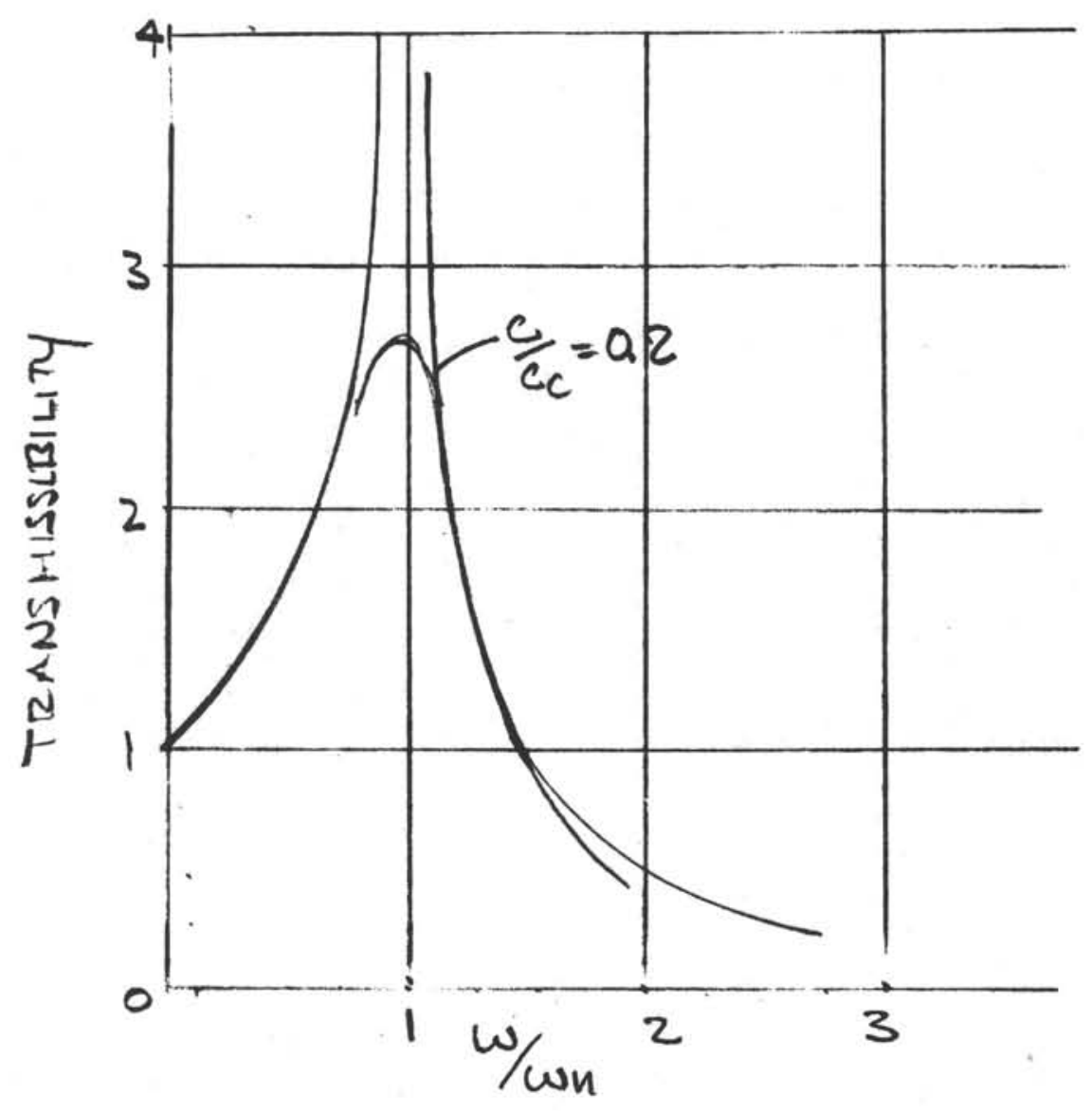

FrOM ANAYYSIS AND TEST THE DAMPING RATE IS SMALl the frequency ratio $\omega / w_{n}$ appears to be $\sim 0.95$ as a consequence the conditions are near resonance consider the damping ratio $/ G_{c}=0.2 \omega / \omega_{n} \sim 1.0$

$$
K_{T}=\sqrt{\frac{1+\left(2(0.2)^{2}\right.}{\left(2 .(0.2)^{2}\right.}}=2.693
$$

W HaN

$$
c_{c_{C}}=0.15 \quad k_{T}=3.5
$$

106 
CONCLUSIONS:

W. Nugent 10. 17.79

1. From tills and previous analysis it is SEen that THE IMPACT CONDITIONS APPROACH OR EXCEED THE BOUNDARY CONDITIONS ( $500 \mathrm{~g}$ AND $5 \mathrm{MS}$ PULSE - $3000 \mathrm{~g}$ INS PULSE) OE THE ACCELEROMETER.

Note! BUlg and 4.85 ms half sine pulse at impact this case. $930 \mathrm{~g}$ AND $1.6 \mathrm{MS} "$ "
$2400 \mathrm{~g}$ AND $2.0 \mathrm{MS} "$ CASE II STUDY
CASE IV STUDY

THE TRANSMISSIBILITY $\sim 2.5$ TO 3 CUD PRODUCE $\sim 1000 \mathrm{~g}$

THE VIBRATION DUE TO FLOW THROUGH DURING DESCENt/ $200-400 \mathrm{~Hz}$ IT IS NOT APPARENT THE THE LOAD FACTOR WOULD BE EXCEED in THIS case

WITHOUT SPECIAL HANDLING \& OR SHOCK I VIBRATION PROTECION THERE APPEARS TO BE HIGH RISK DEPLOYING THE INSTRUMENT package (particularly the accelerometer) In this environment

107 


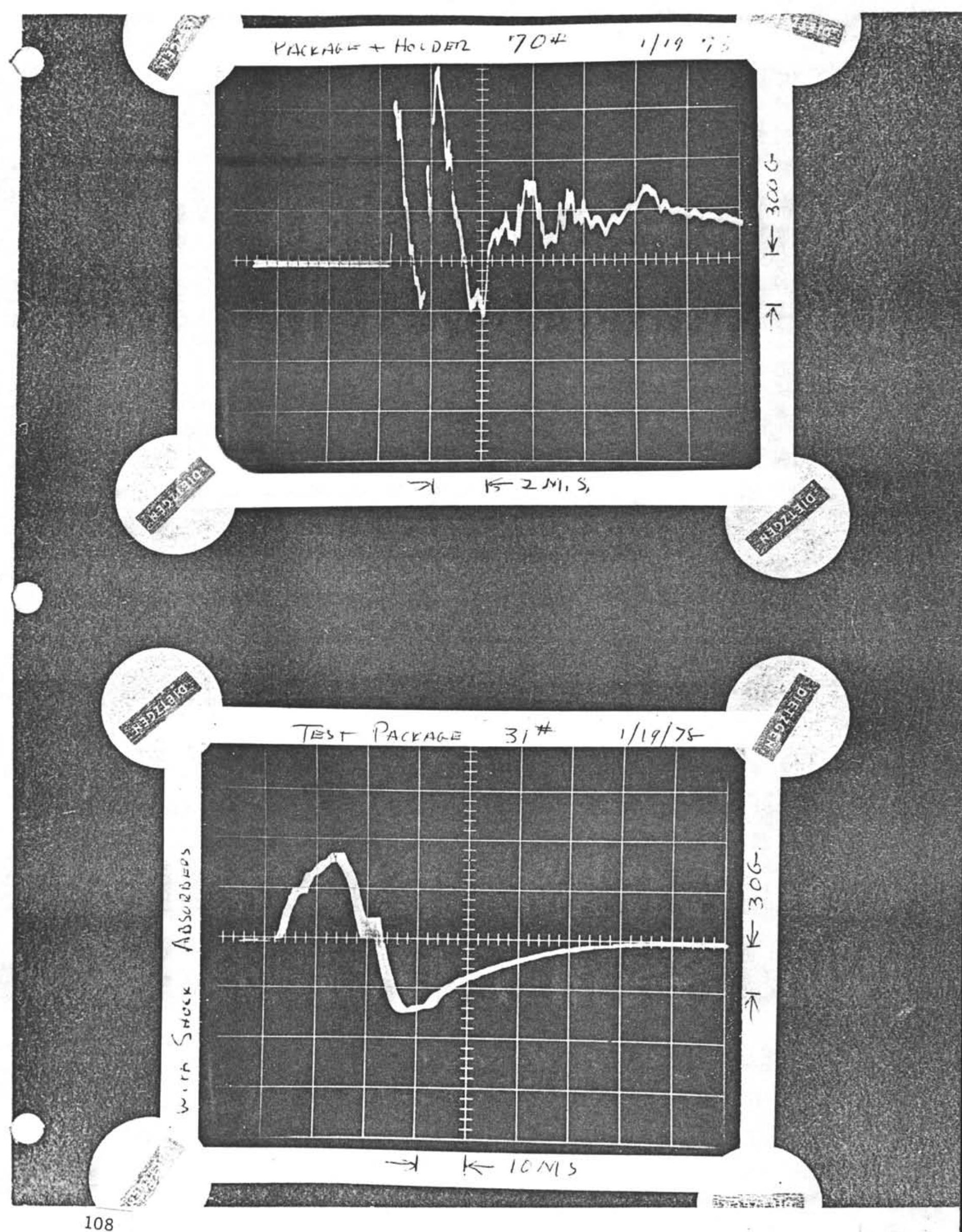


VARIABLE LENGTH HYDRAULIC PISTON CORER (VLHPC)

PARTS LIST AND ASSEMBLY DRAWINGS 
VARIABLE LENGTH HYDRAULIC PISTON CORER (VLHPC)

\section{PARTS LIST - COMPONENTS}

PART

NUMBER

OL 1019

OP 4309

OP 4307

OP 4156

OP 4157

OP 4155

OP 4365

OP 4366

OP 4367

OP 4329

OP 4317

OP 4314

OP 4320

OP 4354

OP 4355

OP 4150

OP 4151

OP 4324

OP 4325

OP 4326

OP 4364

OP 4371

OP 4335

OP 4341

OP 4344

OP 4381

OP 4345

OP 4383

OP 4390

OP 4391

OP 4392
DESCRIPTION

Seal Sleeve

TOP SUB ASSEMBLY

Top Sub Cap

Top Sub Body

Male Adapter F/Top Sub

Female Adapter F/Top Sub

V-Spacer F/Top Sub

SWIVEL ASSEMBLY

Inner Swivel Body

Swivel Retainer

Outer Swive1 Body

SHAFT ASSEMBLY

Bypass Sub (7/32")

Shear Bushing (7/32) F/Bypass Sub

Shaft Connector

$4.5 \mathrm{~m}$ Shaft Link

$3.0 \mathrm{~m}$ Shaft Link

Lower Shaft

INNER SEAL SUB ASSEMBLY

Inner Seal Sub

Inner Sea1 Retainer

Male Adapter F/Inner Seal Sub

Female Adapter F/Inner Seal Sub

V-Spacer F/Inner Seal Sub

PISTON ROD ASSEMBLY

Upper Piston Rod

$4.5 \mathrm{~m}$ Piston Rod Link

$3.0 \mathrm{~m}$ Piston Rod Link

Rod Connector

Lower Piston Rod

PISTON HEAD ASSEMBLY

Q-R Piston Head

Q-R Piston Seal Retainer

Lock Pin - Piston

Male Adapter F/Piston Head

Female Adapter F-Piston Head

V-Spacer F/Piston Head
DRAWING

NUMBER

B-1030

N/A

R-0P4309

B-OP 4307

A-1264

A-1256

A-1266

N/A

B-0P4365

B-OP4366

B-OP4367

R-OP4329

A-OP4317

B-OP 4314

B-OP 4320

B-OP 4354

B-0P4355

N/A

B-0927-0

B-0928

A-OP 4323

A-OP 4325

A-0P4326

N/A

B-0P4364

B-OP4371

B-OP4335

A-OP4341

B-OP4344

N/A

B-0P4381

A-0P4345

A-OP 4383

A-0P4390

A-OP4391

A-OP 4392 
PART

NUMBER

$\begin{array}{ll}\text { OP } & 4312 \\ \text { OP } & 4310 \\ \text { OP } & 4321 \\ \text { OP } & 4318 \\ \text { OP } & 4357\end{array}$

OP 4313

OP 4343

OP 4356

OP 4328

OP 4160

OP 4363

OP 4394

OP 4395

OP 4396

OP 3055

OP 4338

OP 4337

OP 4340

OP 4342

OP 3210

OP 4353

OP 4360

OP 3400

OP 4382

OP 4376

OP 4109

OP 4112

OP 4113

OR 7020
DESCRIPTION

SHEAR PIN ASSEMBLY

Sleeve - Outer Body Cap

Sleeve Ring - Outer Body Cap

Outer Body Cap (7/32)

Shear Bushing (7/32) F/Outer Body Cap

7/32" Dia. Shear Pin

OUTER BODY ASSEMBLY

Outer Body Vent

4.5 m Outer Body Link

3.0 m Outer Body Link

Lower Outer Body

OUTER SEAL SUB ASSEMBLY

Outer Seal Sub

Outer Seal Retainer

Male Adapter F/Outer Seal Sub

Female Adapter F/Outer Seal Sub

V-Spacer F/Outer Seal Sub

QUICK DISCONNECT ASSEMBLY

Q/R Shoulder Sub

Q/R Cap Sub

Sleeve - Q/R Shoulder Sub

Dogs - Q/R Shoulder Sub

INNER BARREL ASSEMBLY

Upper Liner Sea1 Sub

$4.5 \mathrm{~m}$ Inner Core Barrel

$3.0 \mathrm{~m}$ Inner Core Barre1

Lower Liner Seal Sub

Core Liner

Plastic Tube Support (VLHPC)

CORE CATCHER ASSEMBLY

Catcher Sub

Spring, Flapper Core Catcher

Flapper, Flapper Core Catcher

Cylinder, Flapper Core Catcher

Dog (8) Type Core Catcher
DRAWING

NUMBER

N/A

A-OP 4312

A-OP 4310

A-OP4321

A-0P4318

A-OP 4357

N/A

B-OP 4313

B-OP 4343

B-0P4356

B-OP4328

N/A

C-0921

A-OP 4363

A-0P439.4

A-0P4395

A-0P4396

$\mathrm{N} / \mathrm{A}$

R-OP 3055

C-OP4338

B-OP4337

B-OP 4340

$\mathrm{N} / \mathrm{A}$

B-OP4342

B-WL-21

B-0P4353

B-0P4360

A- 1230

A-0P4382

N/A

B-OP4376

A-1290

B-1296

B-1297

A-0191 
VARIABLE LENGTH HYDRAULIC PISTON CORER (VLHPC) PARTS LIST - WIRELINE

PART

NUMBER

OP 4347

OP 4350

OP 4349

OP 4358

OP 4351

\section{DESCRIPTION}

Single Shot Pressure Case

Single Shot Top Plug F/Pressure Case

Single Shot Bottom Plug F/Pressure Case

Pipe Plug F/Bottom Plug

Non-Magnetic Sinker Bar

KUSTER SINGLE SHOT ASSEMBLY

0-20 Angle Unit (short)

Battery Case, 5 Cell*

Electronic Timer**

Main Frame, Short

Spacer Tube, Short

E.T. Test Sleeve

Anchor

Plug

Tang

Anchor Screw

Set Screw

Nose Spring 6"

$0-$ Ring

Film Disc Loader

Developing Tank

Carrying Case - S.S.

Disco Reader

Orientation Reader

Non-Steel Jacketed Batteries (1.5 V C-size

(Hot Shot Prod. Col.)
DRAWING NUMBER

B-0P4347

B-OP 4350

B-OP 4349

A-OP 4358

B-OP4351

KUSTER P/N

2299-101

4030-105

3600-101

4100-102

4104-101

3601-000

6221-001

6221-002

6221-003

6221-004

791-049

6221-001

6205-001

4301-100

4401-100

4600-000

4602-000

4604-000

*Battery Case, 3-Ce11

4030-103

**Clock, 90 minutes

3201-101

Flash Unit

4025-101 
VARIABLE LENGTH HYDRAULIC PISTON CORER (VLHPC)

PARTS LIST - SET SCREWS, ETC.

PART

NUMBER

OP 4302

OP 4301

OP 4369

OP 4361

OP 4185
DESCRIPTION

1/2-13 × 3/4 Socket Set Screw F/Top Sub Cap

1/2-13 x 3/4 Socket Set Screw F/Q.R. Sleeve

1/2-20 x 3/4 Socket Head Cap Screw F/Overshot Alignment

5/8-11 x 1/2 Socket Set Screw F/Outer Swivel Body A-OP4369

3/8-16 x 3/8 Socket Set - Half Dog

Core Liner Retainer Screw F/Upper Liner Seal Sub

3/8-16 $\times 3 / 8$ Socket Set Screw Fi4.5 m Shaft Link

3/8-16 x 3/8 Socket Set Screw F-3.9 m Shaft Link

3/8-16 × 3/8 Socket Set Screw F/Inner Seal Sub

3/8-16 × 3/8 Socket Set Screw F/Lower Outer Body

$3 / 8-16 \times 3 / 8$ Socket Set Screw F/Outer Shaft

3/8-16 $\times 3 / 8$ Socket Set Screw F/Outer Sea1 Sub

3/8-16 × 3/8 Socket Set Screw F/Swivel Retainer
DRAWING

NUMBER

A-OP 4302

$\mathrm{A}-\mathrm{OP} 4302$

A-0P4301

A-OP4361

A. -1471

A- 1471

A-1471

A- 1471

A-1471

A-1471

A-1471

NOTE: All set screws are alloy steel with cadmium plating and nyloc locking. 
VARIABLE LENGTH HYDRAULIC PISTON CORER (VLHPC)

PARTS LIST - ANCILLARY TOOLS

PART

NUMBER

OP 4192

OP 4330

OP 4331

OP 4332

OP 4334

OP 4389

OP 4327

OP 4384

OP 3615

OP 4305

OC 1080

OP 4333
DESCRIPTION

Hang Off Plate

Sighting Bar - Baseline Orientation

Telescope Frame - Baseline Orientation

Sighting Bar Reducer

Orientation Hold Down Strap

Dril1 Jig - Core Liner Orientation Lock

Quick Release Nose Guard

Assembly Bar for Swivel Assembly

Face Spanner Wrench F/Outer Seal Retainer Assembly

Parmelee Wrench (1.25 dia) F/Piston Rod Assembly

Parmelee Wrench (2.18 dia) F/P Case Assembly

HPC - Handling Clamp

Non-Magnetic Drill Collar

Magnetic Pickup \& Stud Finder (Craftsman 94001)

Spanner Wrench

Seal Installation Tool-Single Shot Pressure Case

XCB Core Bit (10 7/32 × $313 / 16)$

Core Orientation Baseline Adjustment
D-1694

DRAWING

NUMBER

B-0942

C-OP4330

C-0P4331

B-OP 4332

A-OP4334

A-0P4389

R-OP 4327

A-OP4384

C-OP3615

A-0P4305

B-OP4333 
VARIABLE LENGTH HYDRAULIC PISTON CORER (VLHPC)

PARTS LIST - ANCILLARY DRAWINGS

PART

NUMBER

OP 4300

OP 4311

OP 4348
DESCRIPTION

Variable Length Hydraulic Piston Corer Assembly

VLHPC System Schematic

VLHPC Single Shot Assembly
DRAWING

NUMBER

R-OP4300

C-OP4311

$\mathrm{R}-0 \mathrm{P} 4348$ 
VARIABLE LENGTH HYDRAULIC PISTON CORER (VLHPC) PARTS LIST - SEALS, 0-RINGS, BACK-UP RINGS

PART

NUMBER

OP 4158

OP 4154

OP 4393

OP 4179

OP 4148

OP 4165

OP 4147

OP 4306

OP 4385

OP 4303

OP 4304

\section{DESCRIPTION}

Top Sub Seal (3.63 x 2.87)

Inner Seal Sub Seal $(2.87 \times 2.25)$

Outer Seal Sub Seal ( $1.87 \times 1.25)$

Piston Head Seal (2.00 x 2.62)

O-Ring F/Shaft Connectors

0-Ring F-Alternate Bypass Sub - 7/32

o-Ring F/Inner Seal Sub

0-Ring F/Outer Seal Sub

0-Ring F/Upper Liner Seal Sub

O-Ring F/Lower Liner Seal Sub

0-Ring F/Single Shot Bottom Plug

o-Ring F/Single Shot Top Plug

Parbac F/Single Shot Bottom Plug

Parbac F/Single Shot Top Plug

Polypac F/Inner Swivel

Polypac Alt. F/Single Shot

Top \& Bottom P1ugs
VENDOR

NUMBER

$37502850 \mathrm{VP}$

$31202250 \mathrm{VP}$

$31201250 \mathrm{VP}$

31202000VP

2-326

2-326

2-326

2-231

2-232

2-232

2-324

2-324

8-324

8-324

18702375

18701375 


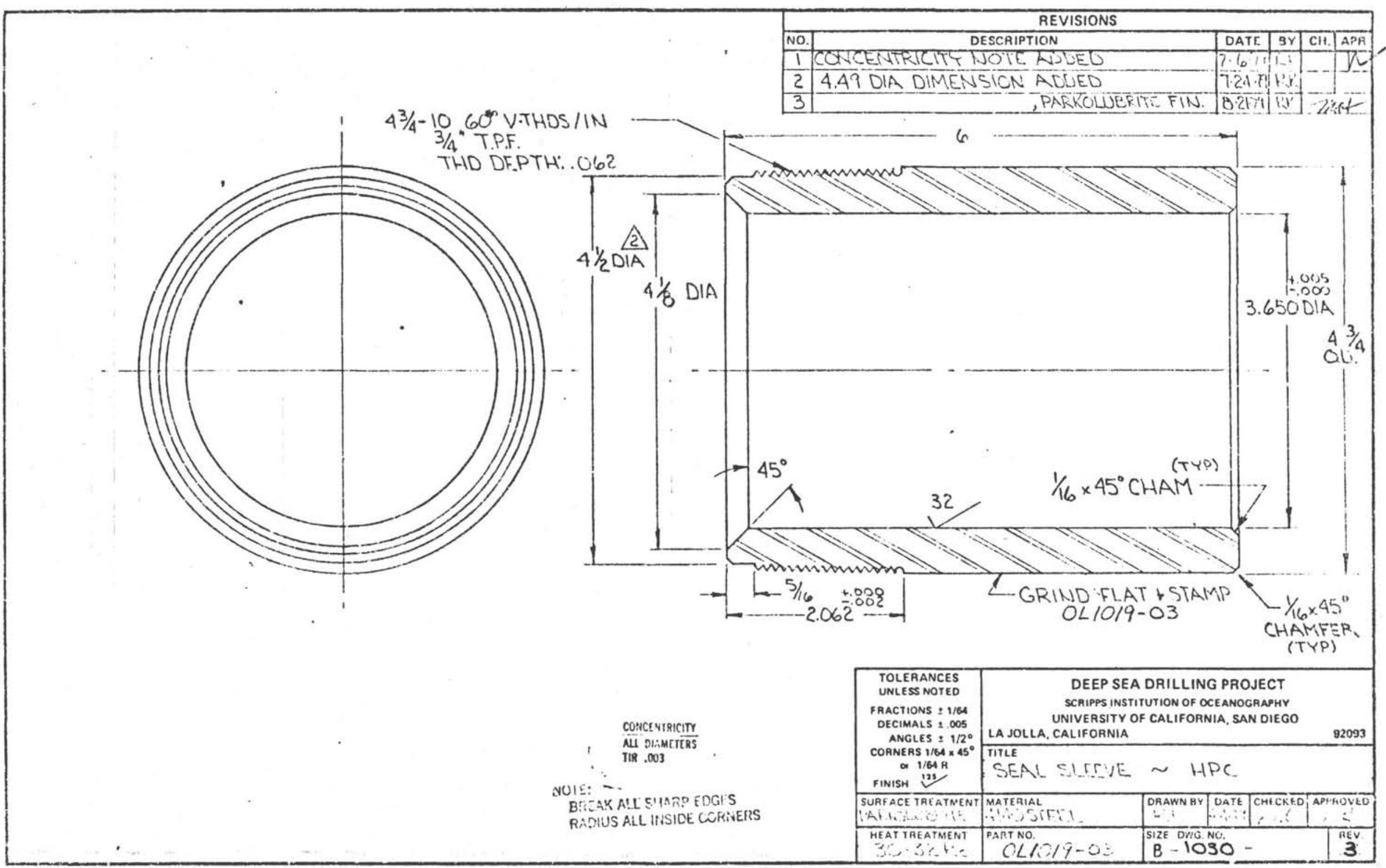




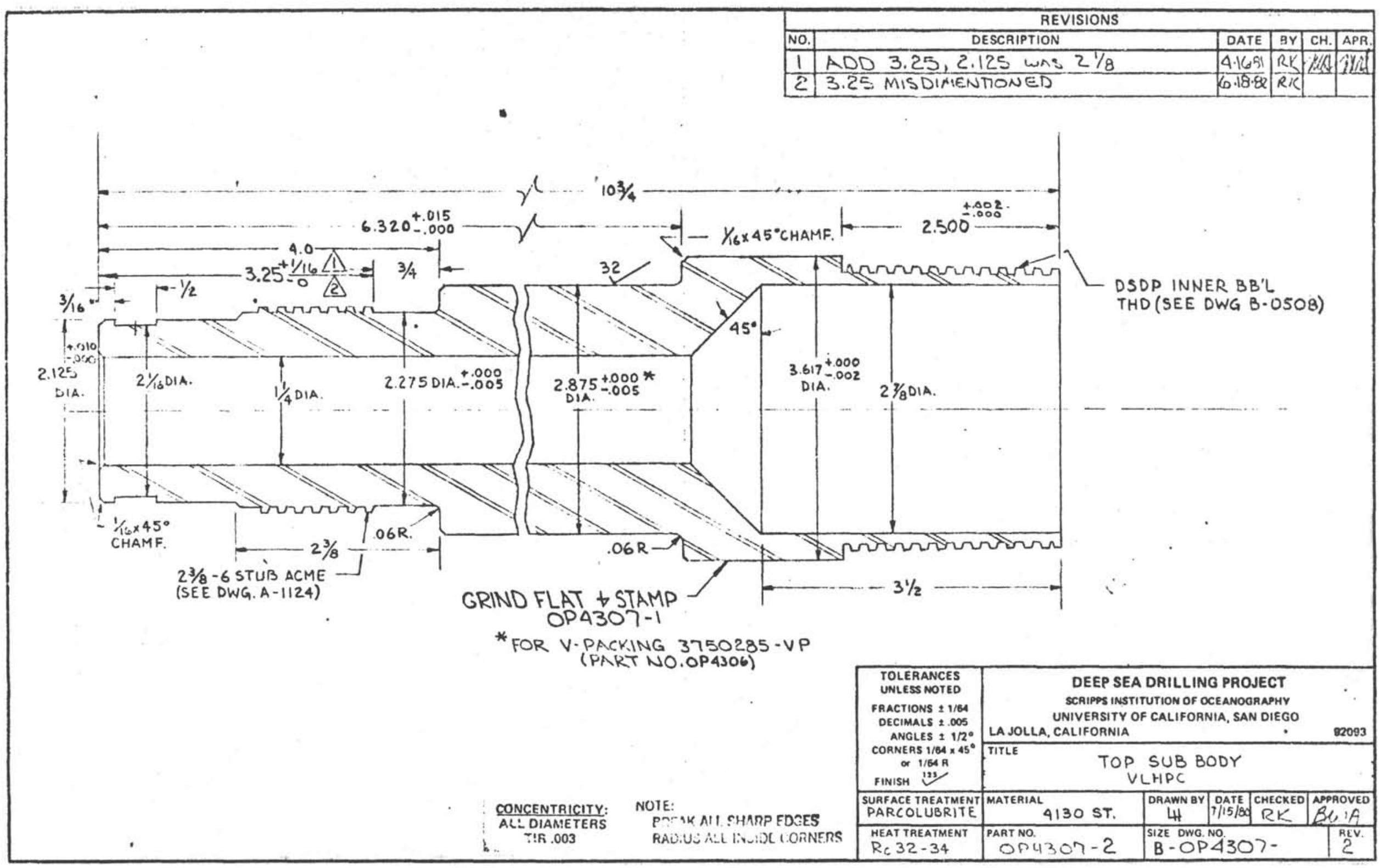




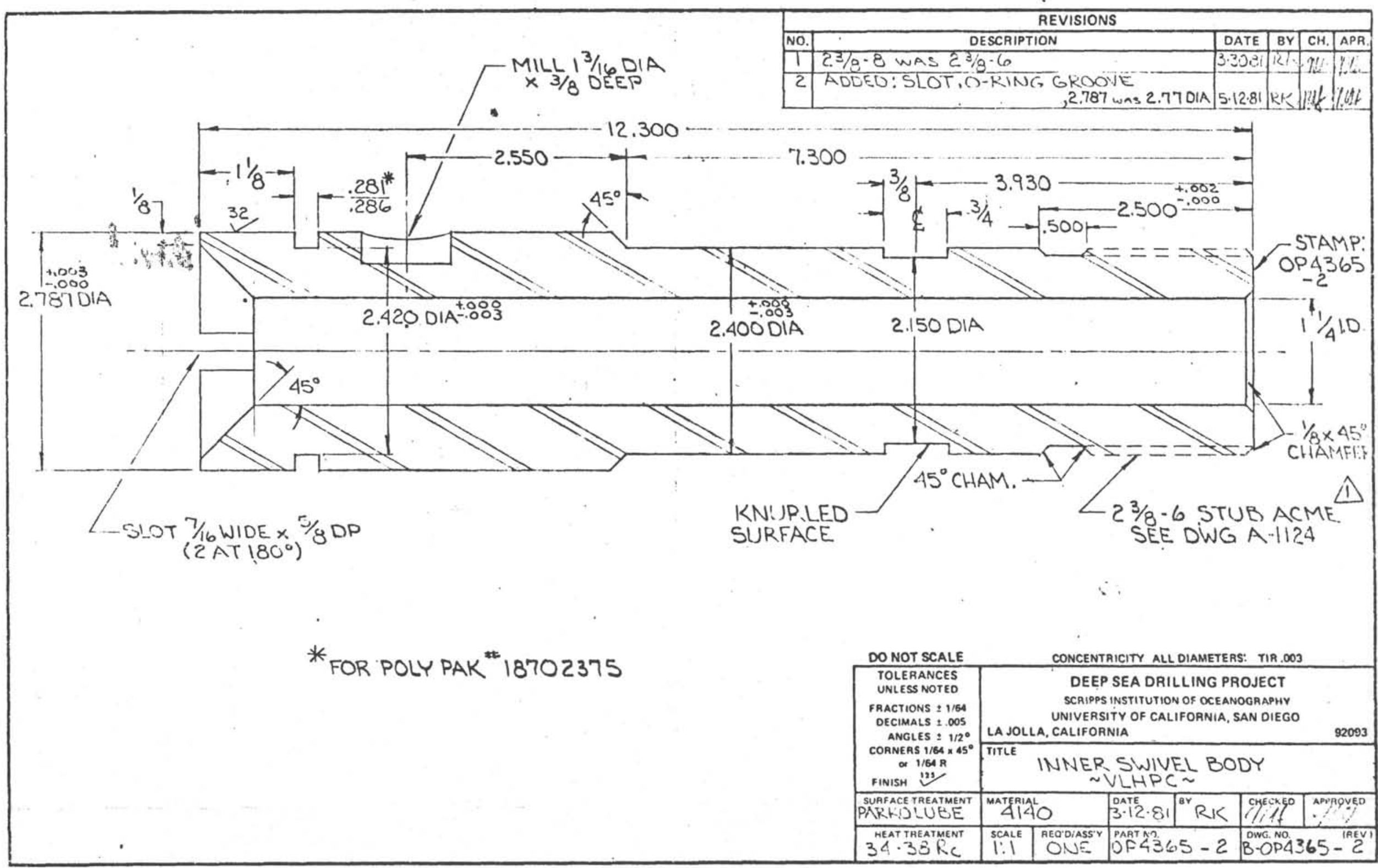




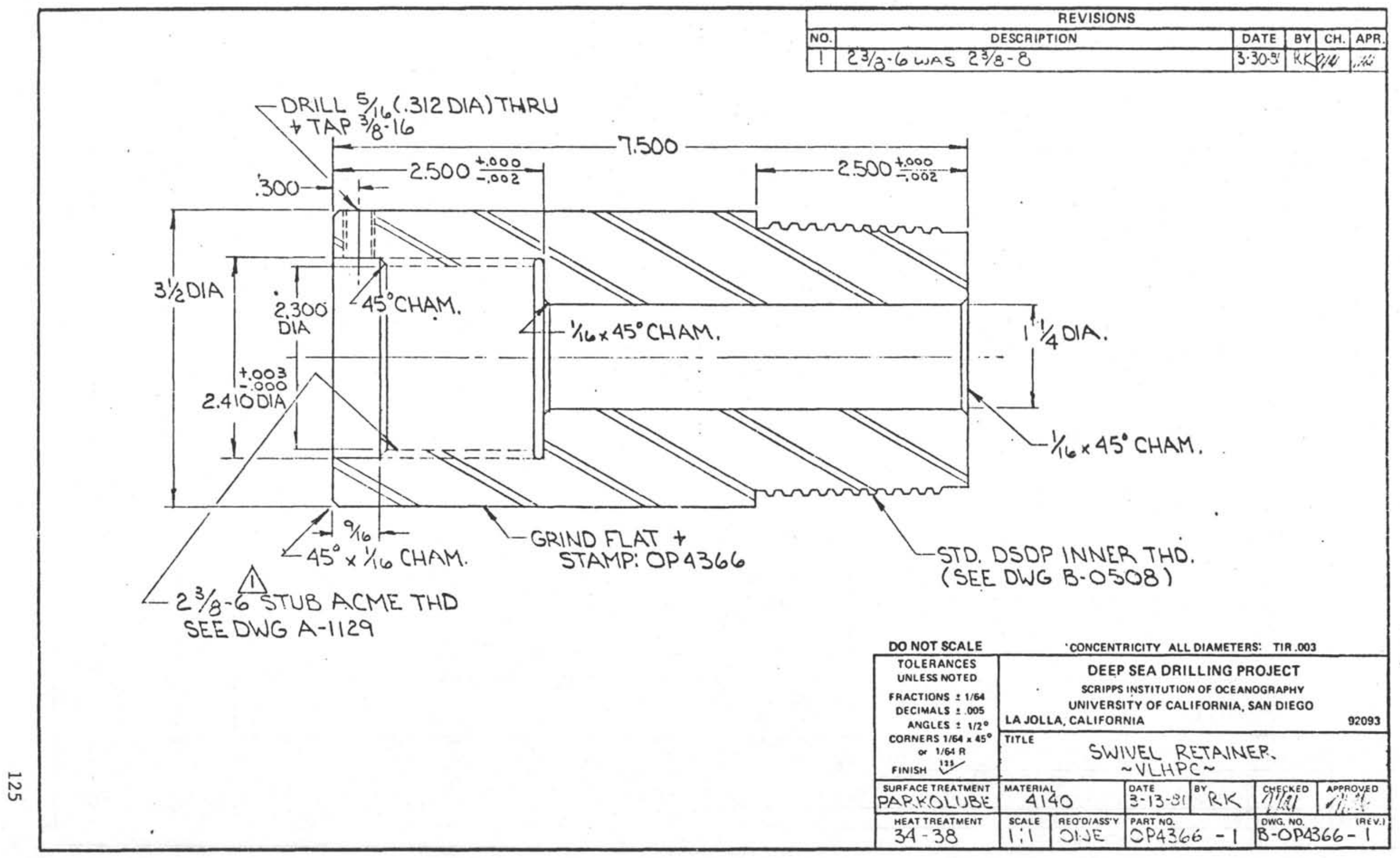




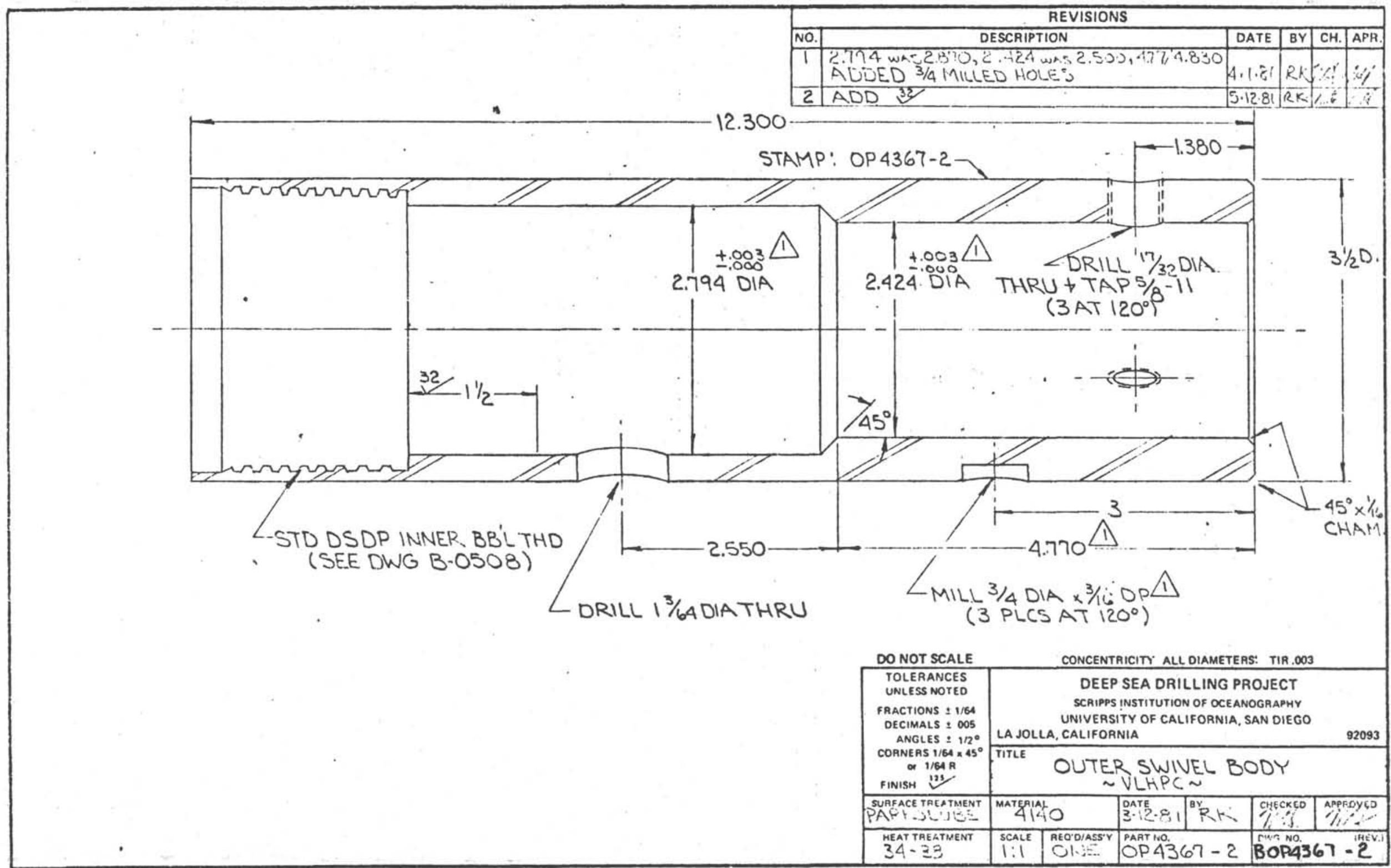




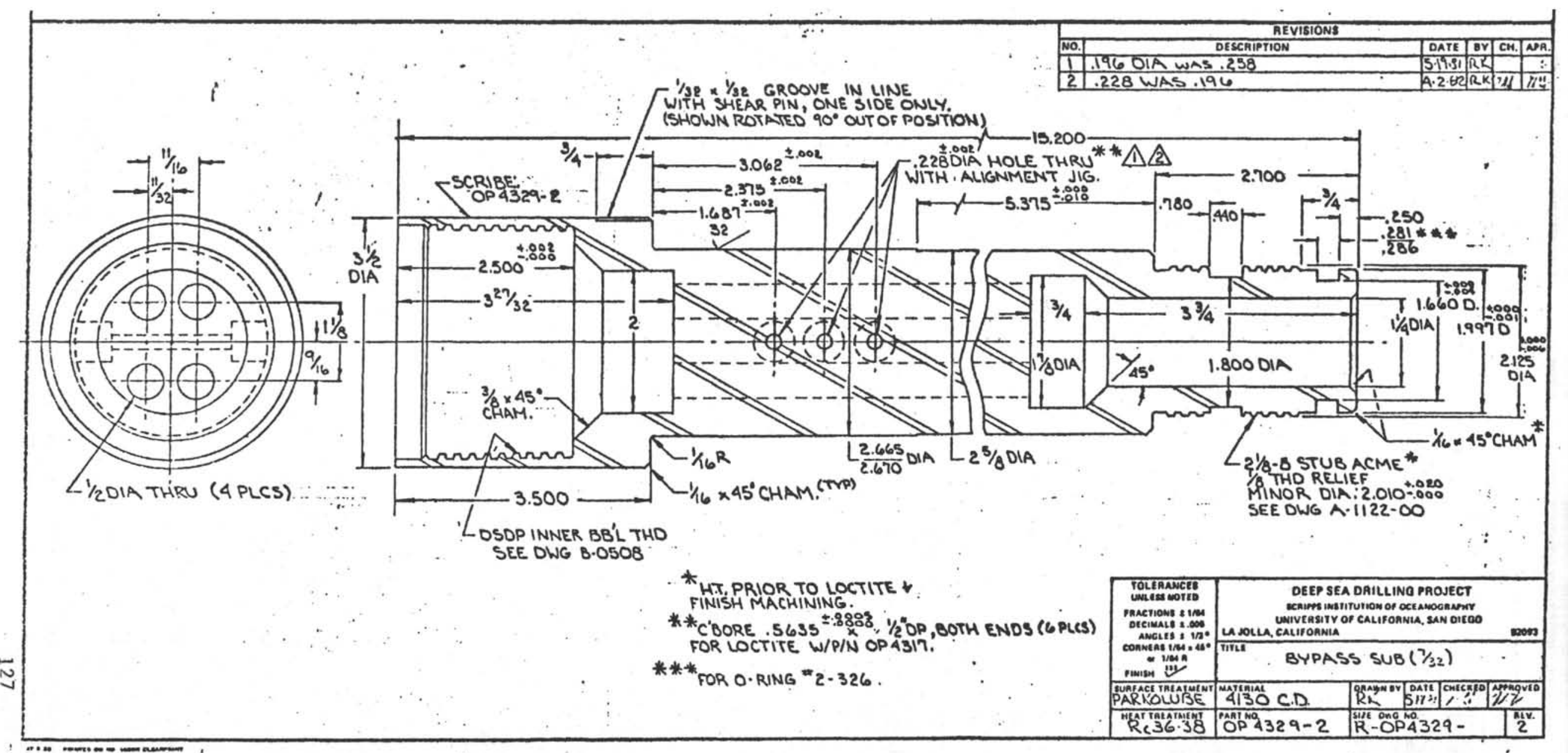




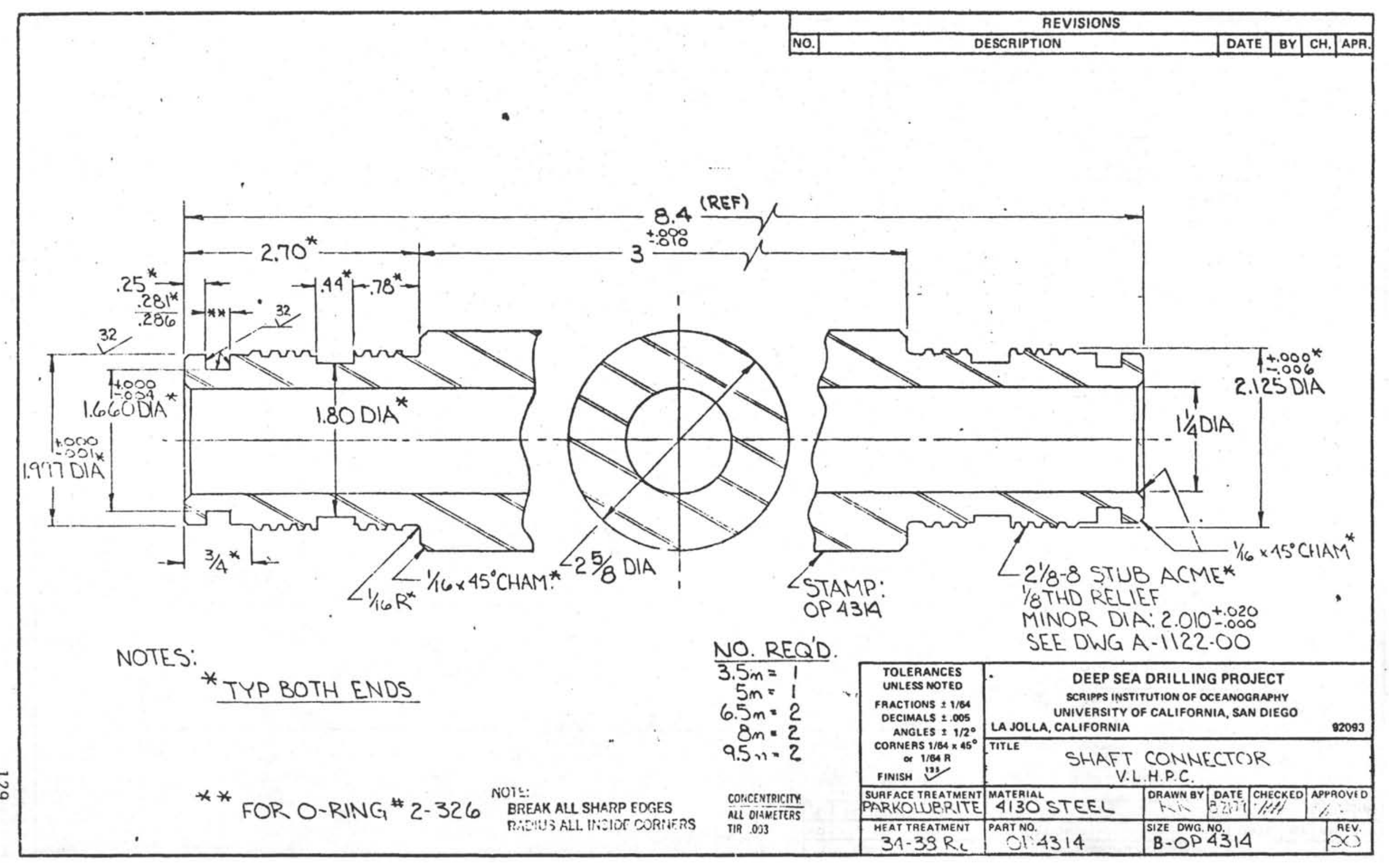




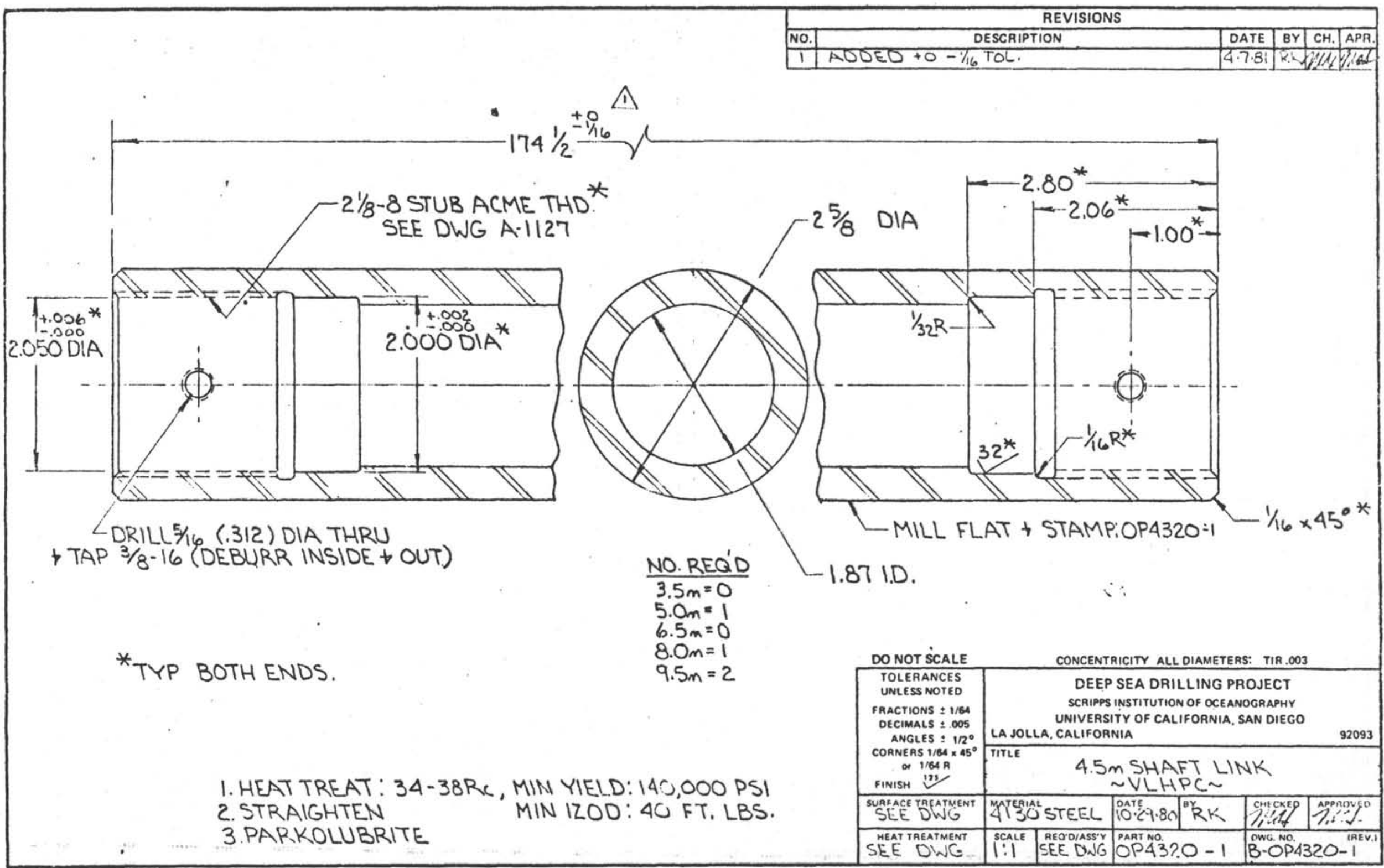




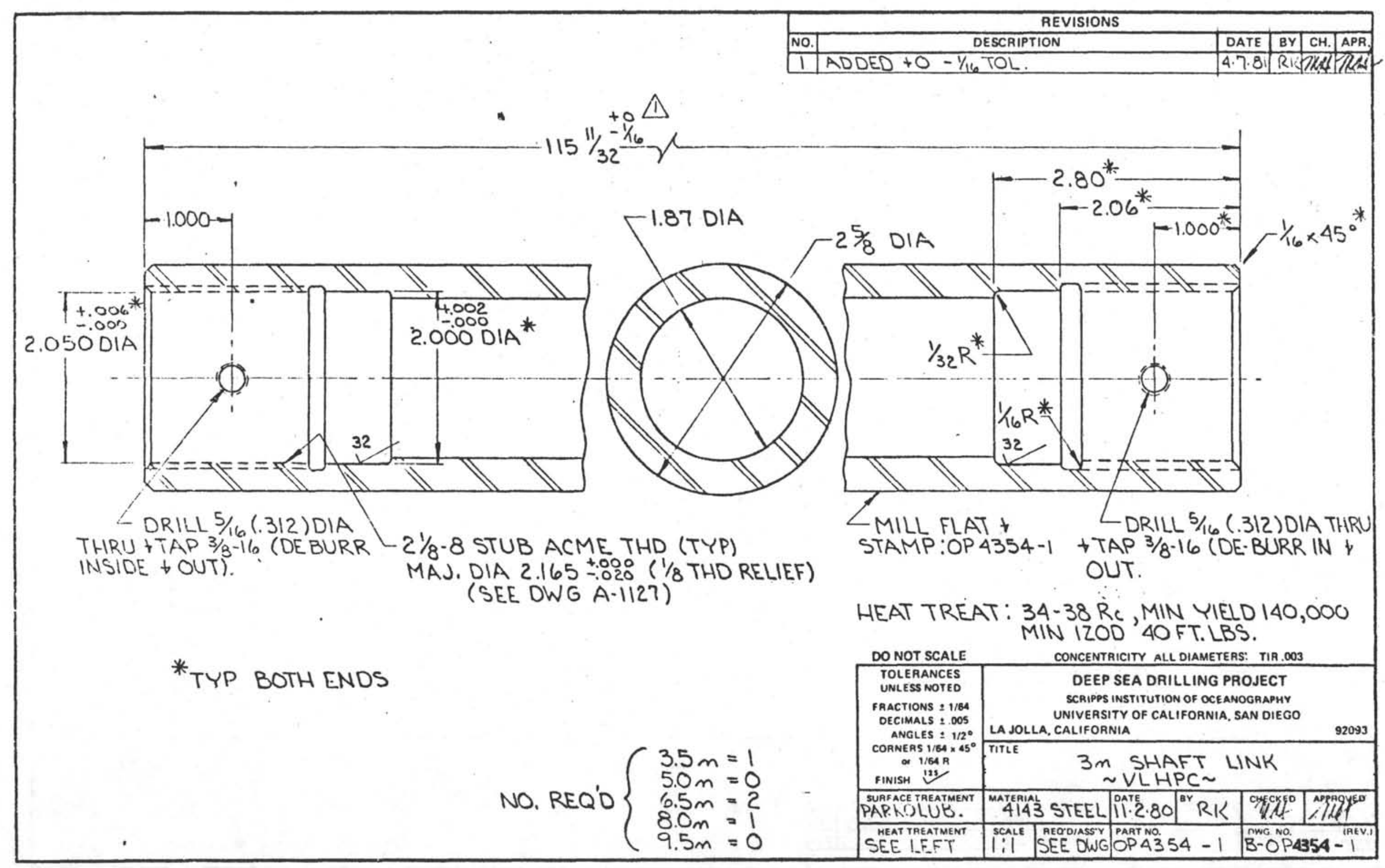




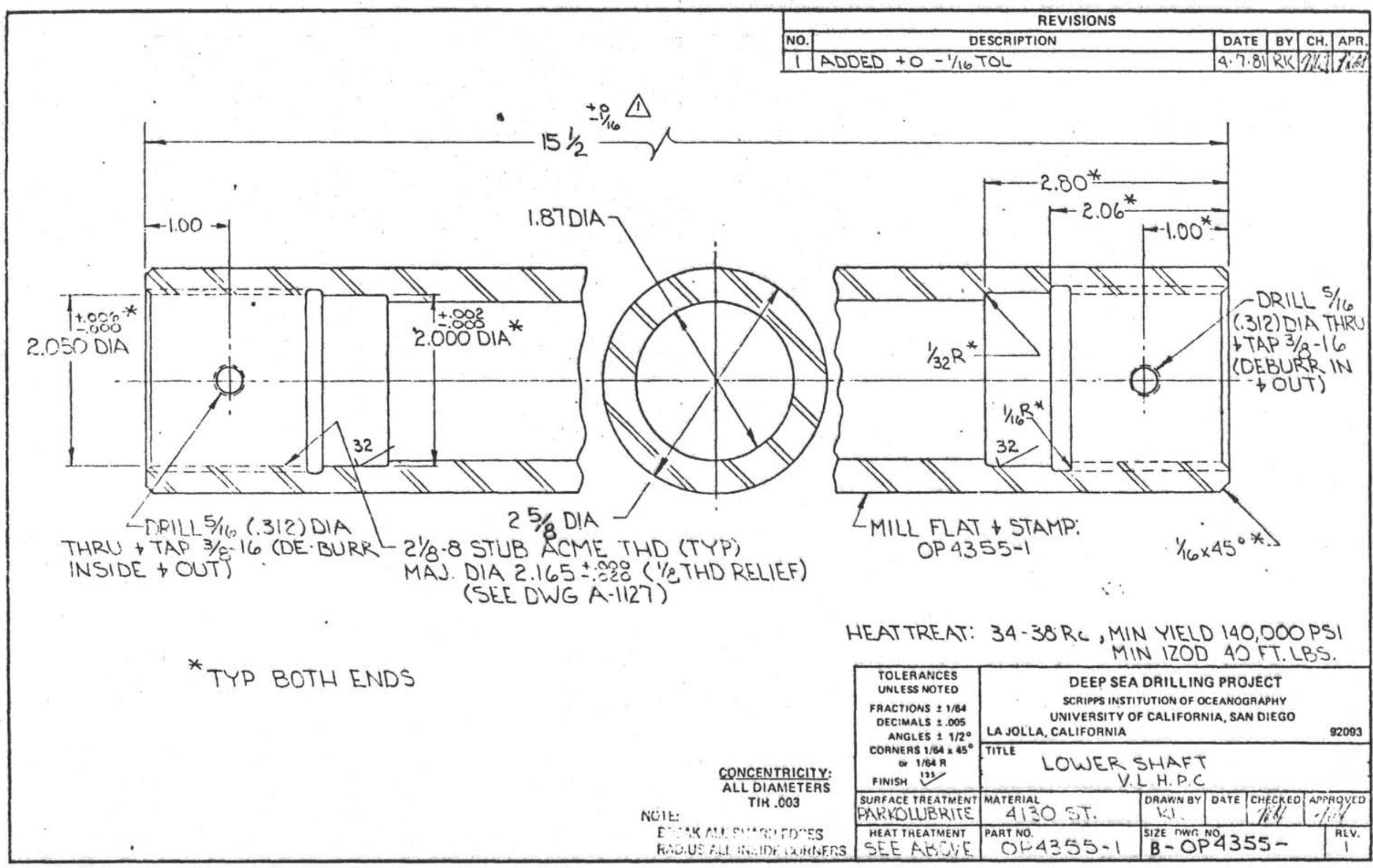




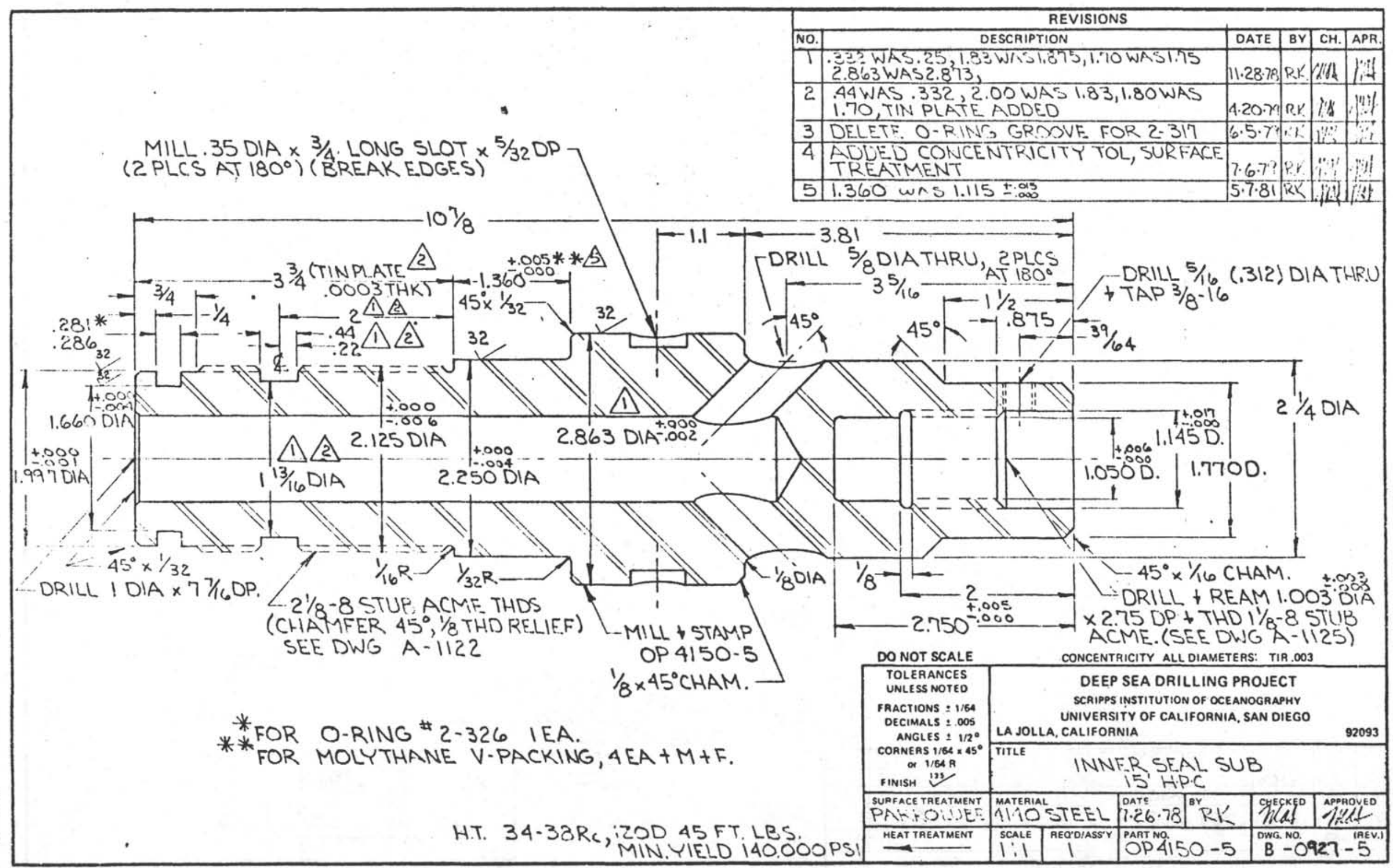




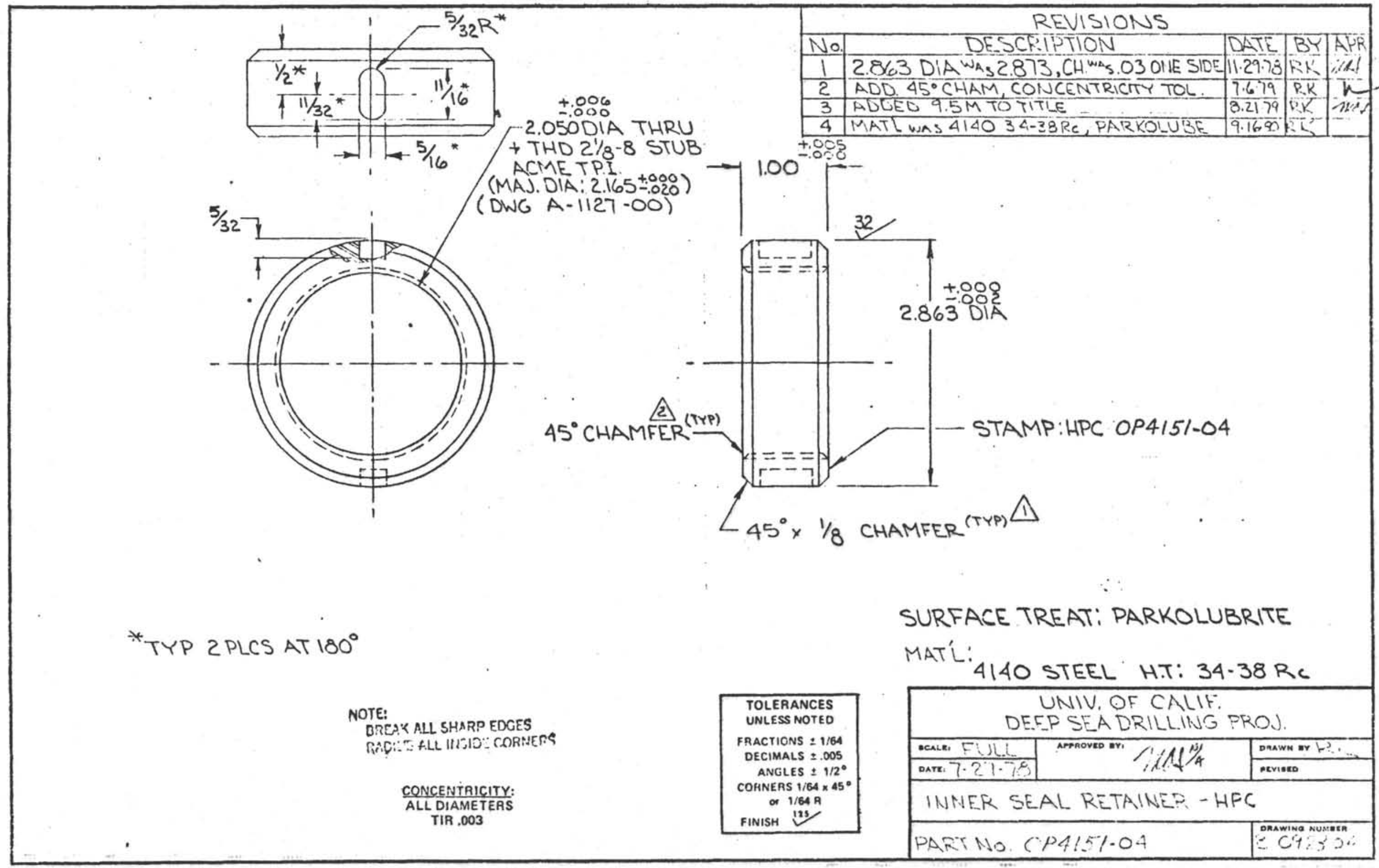




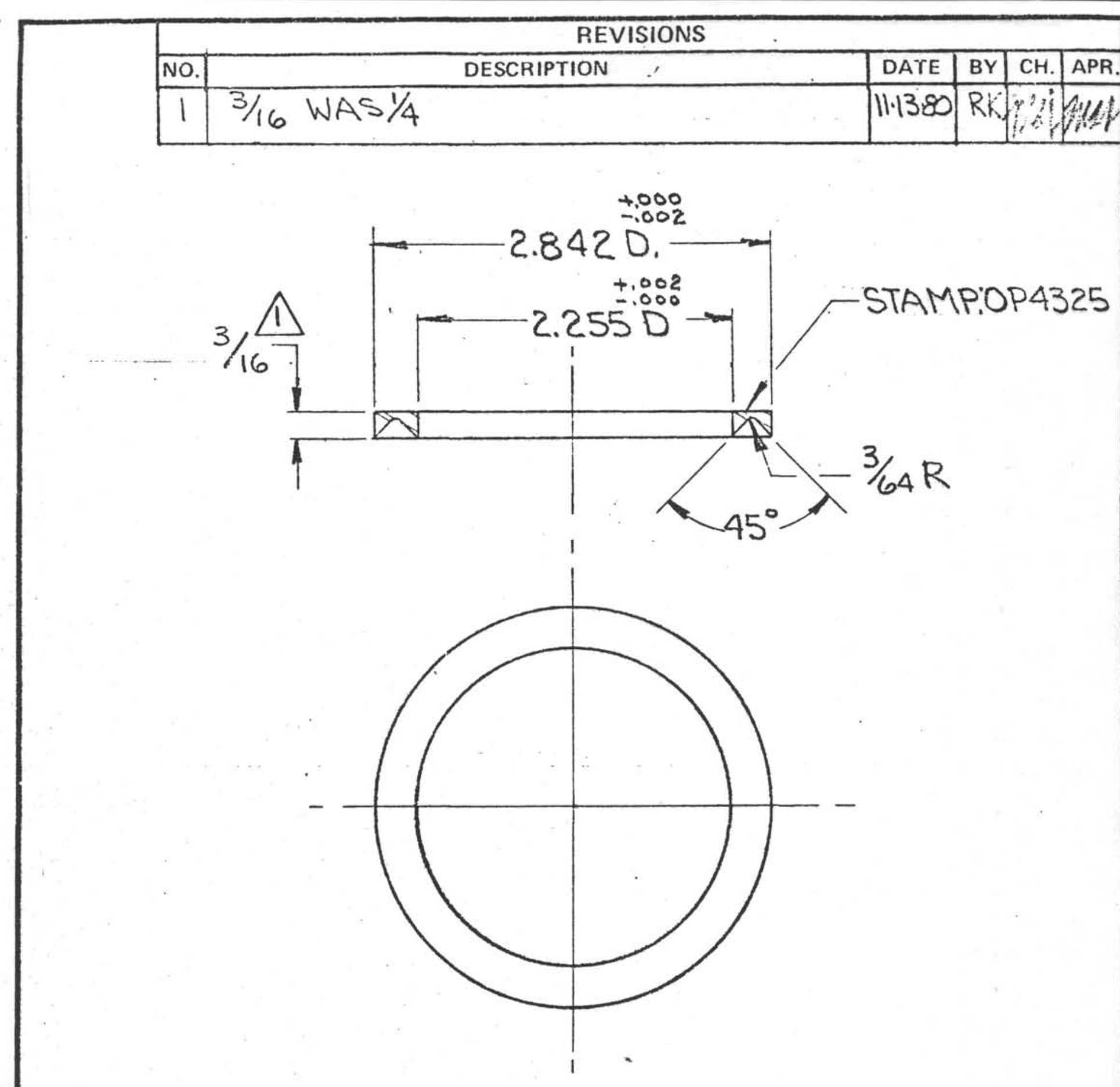




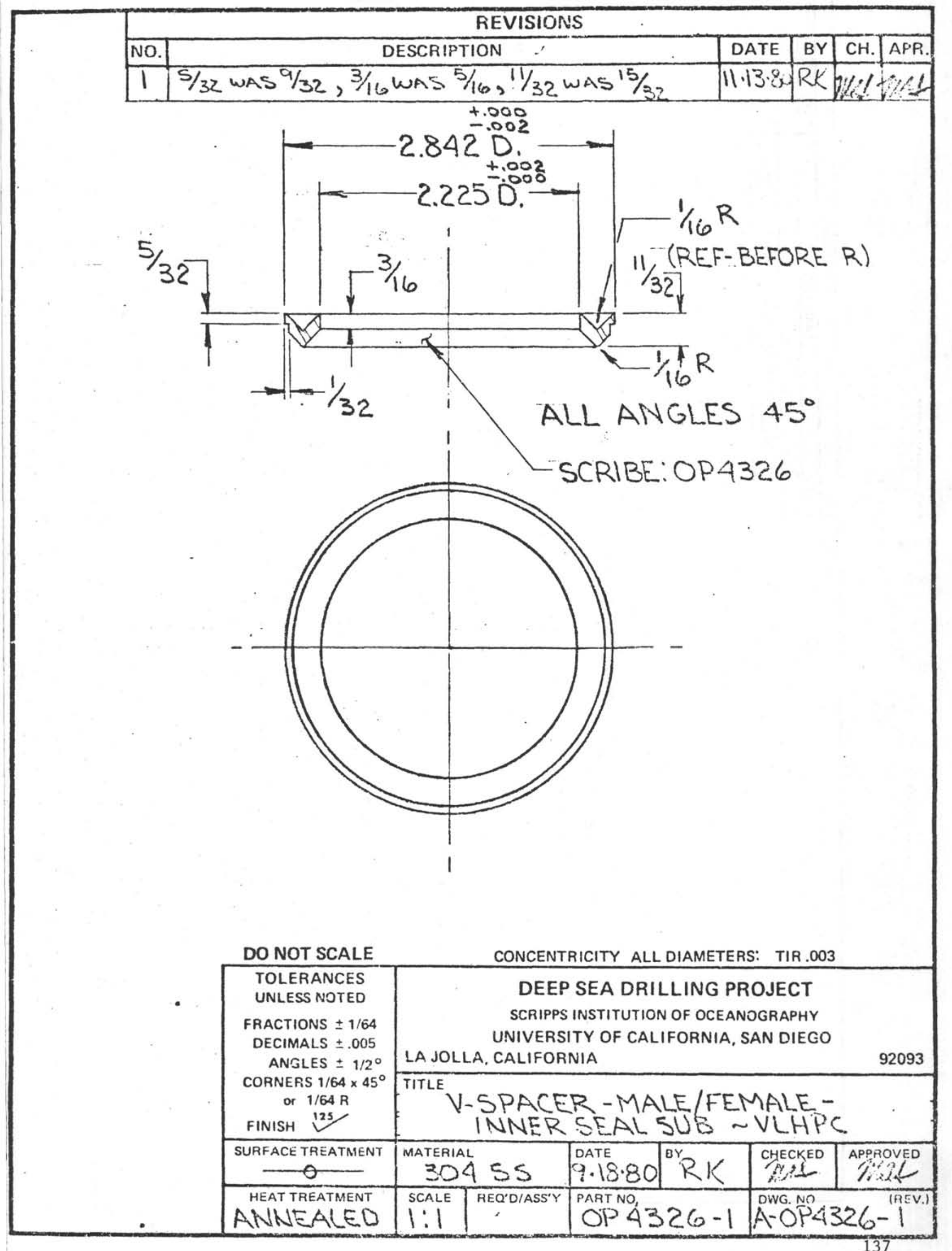




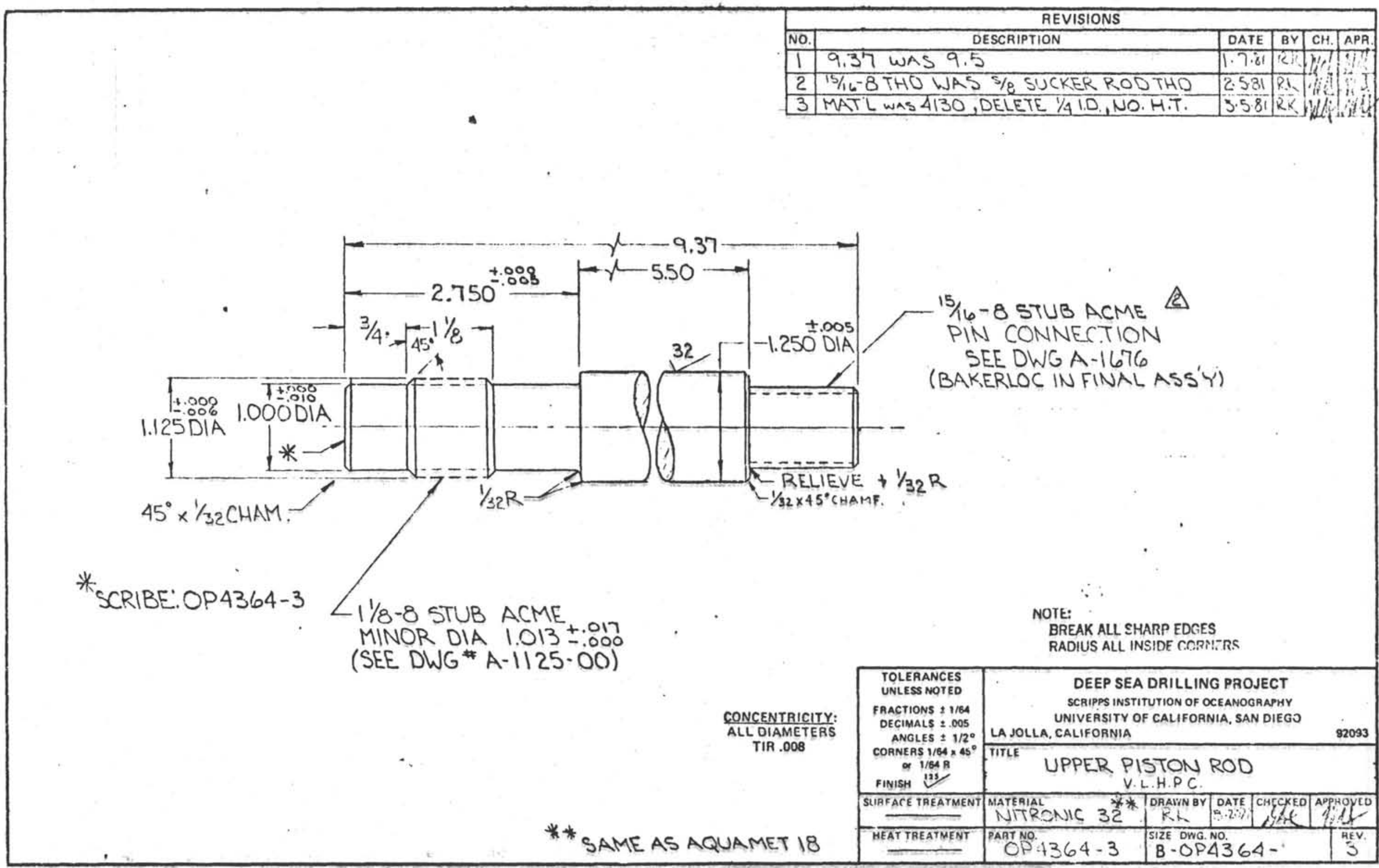




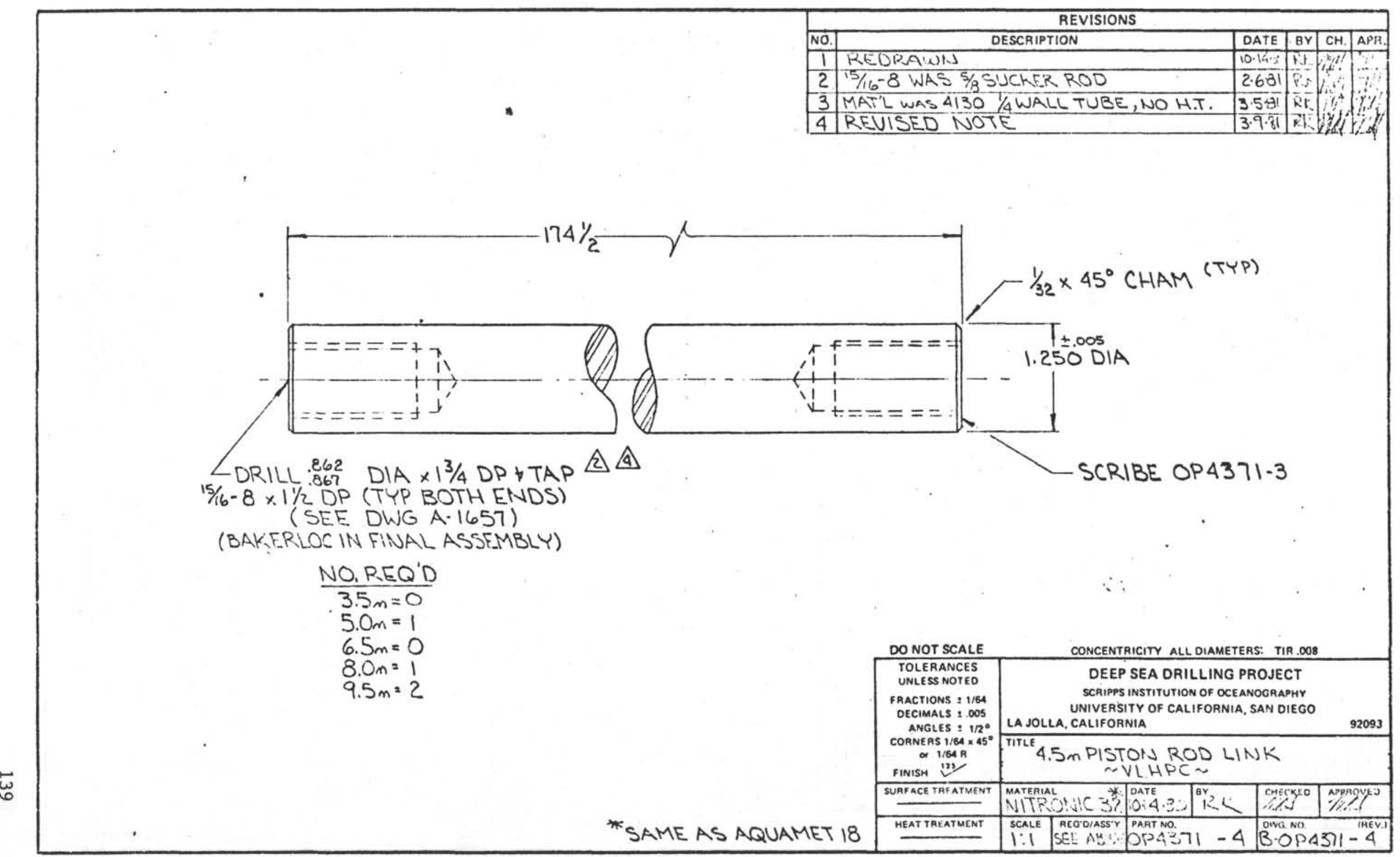




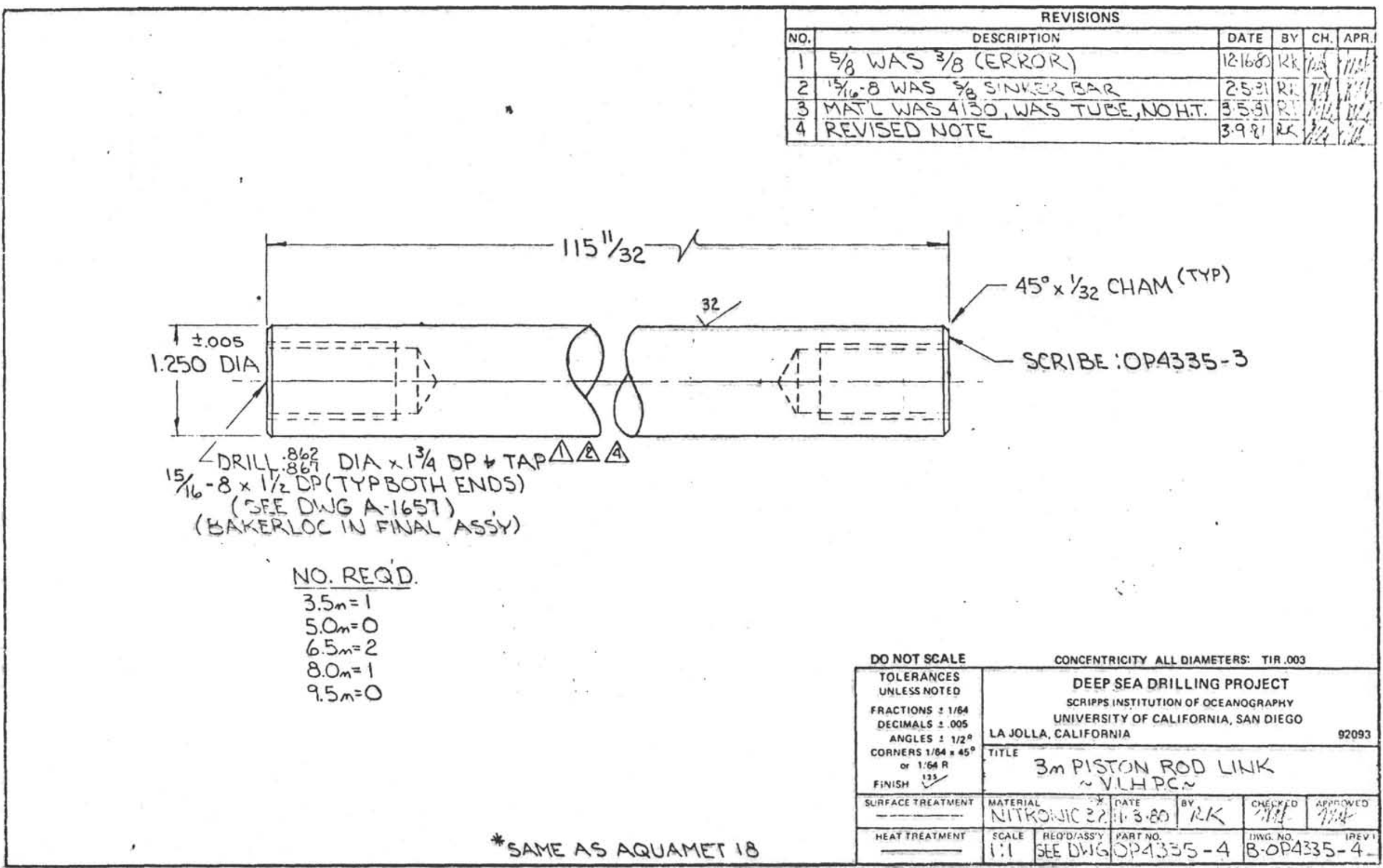




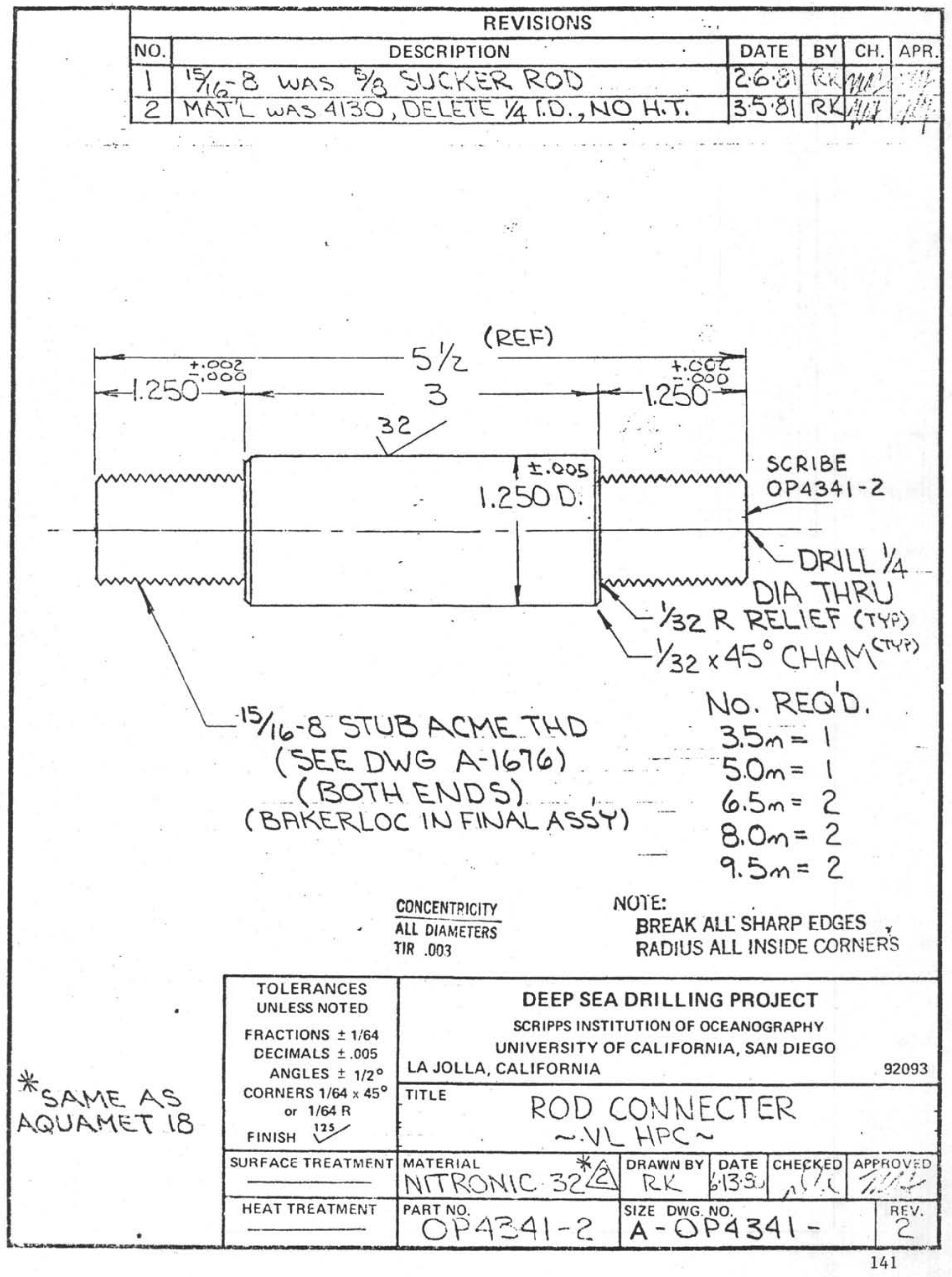




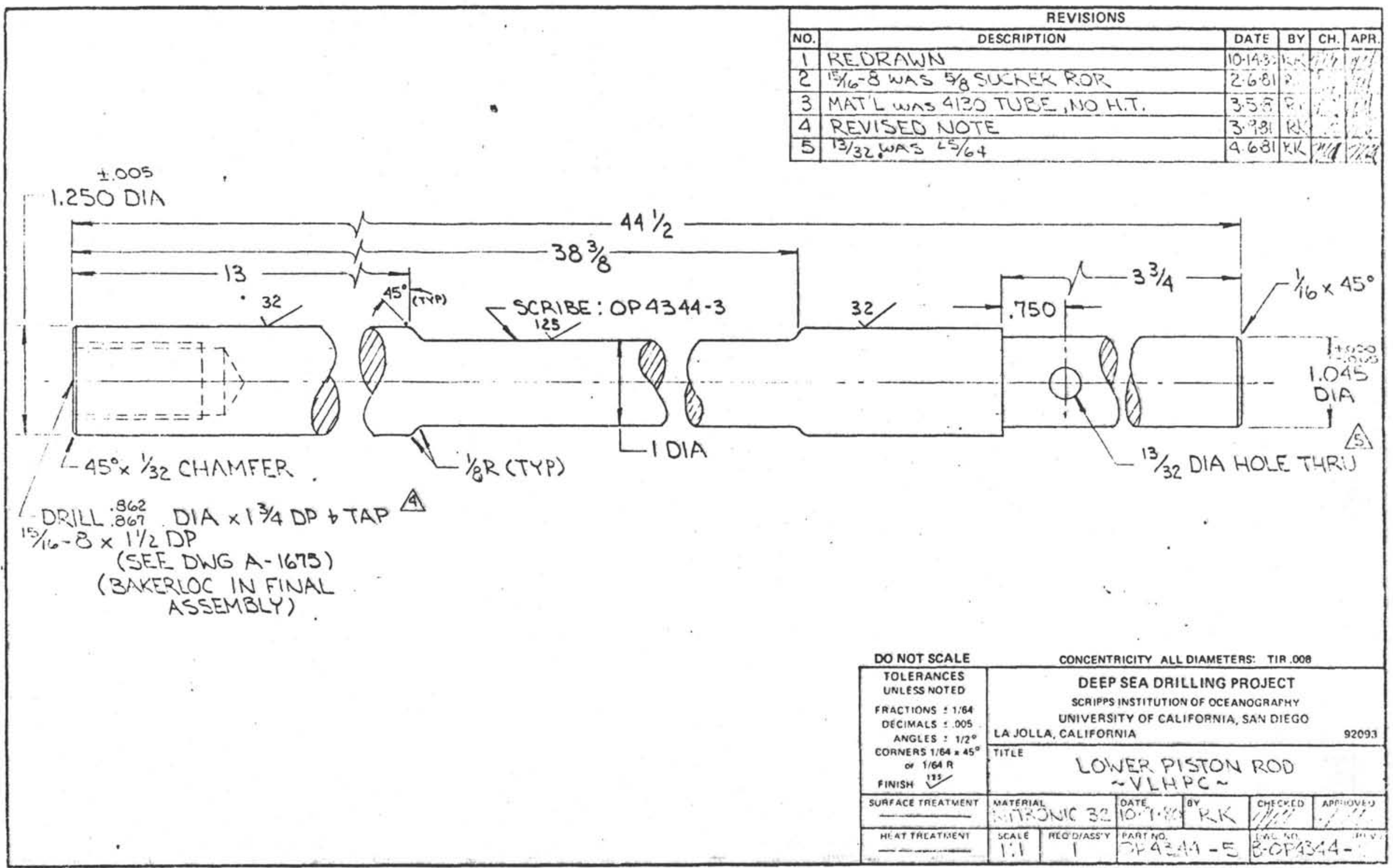




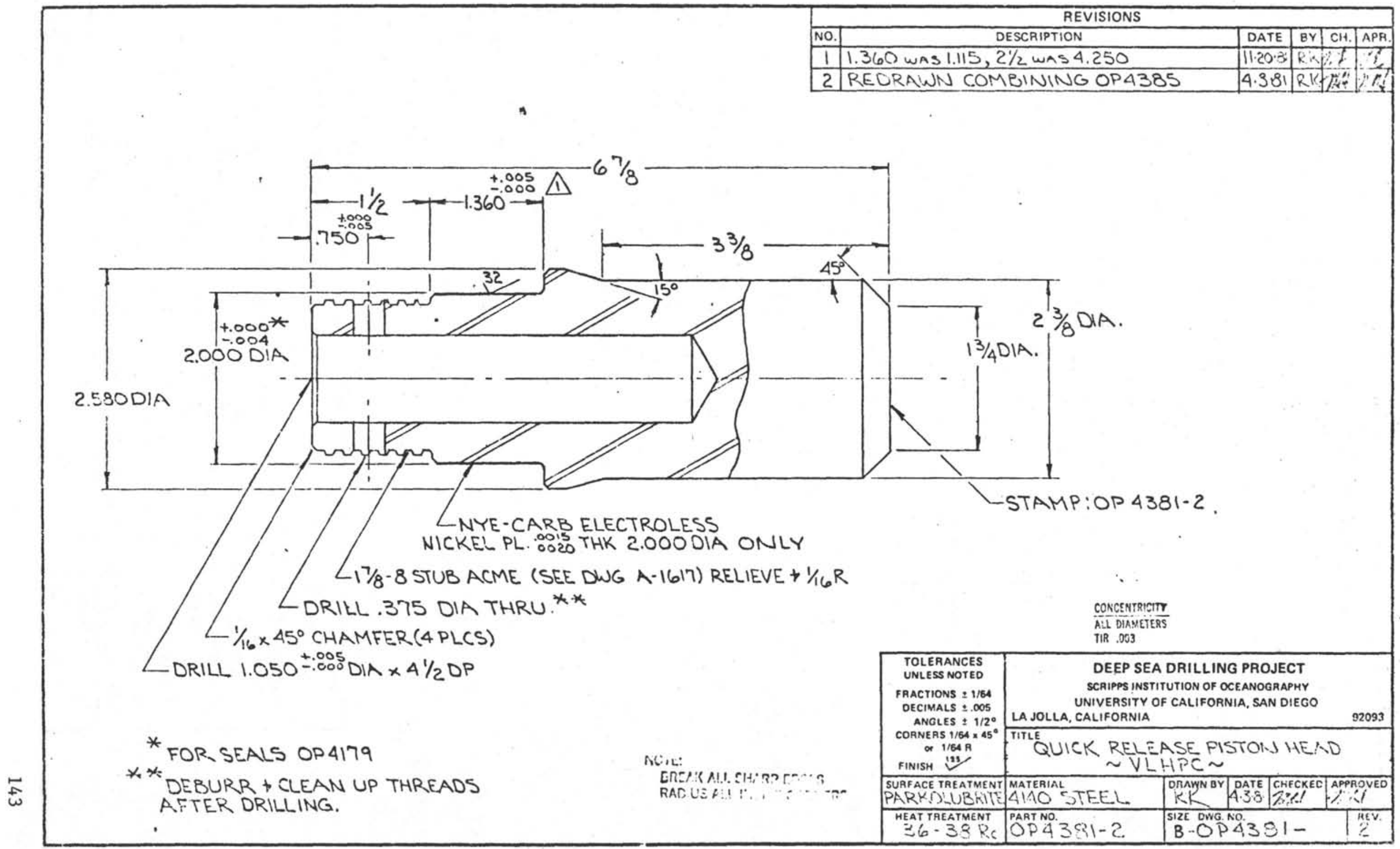




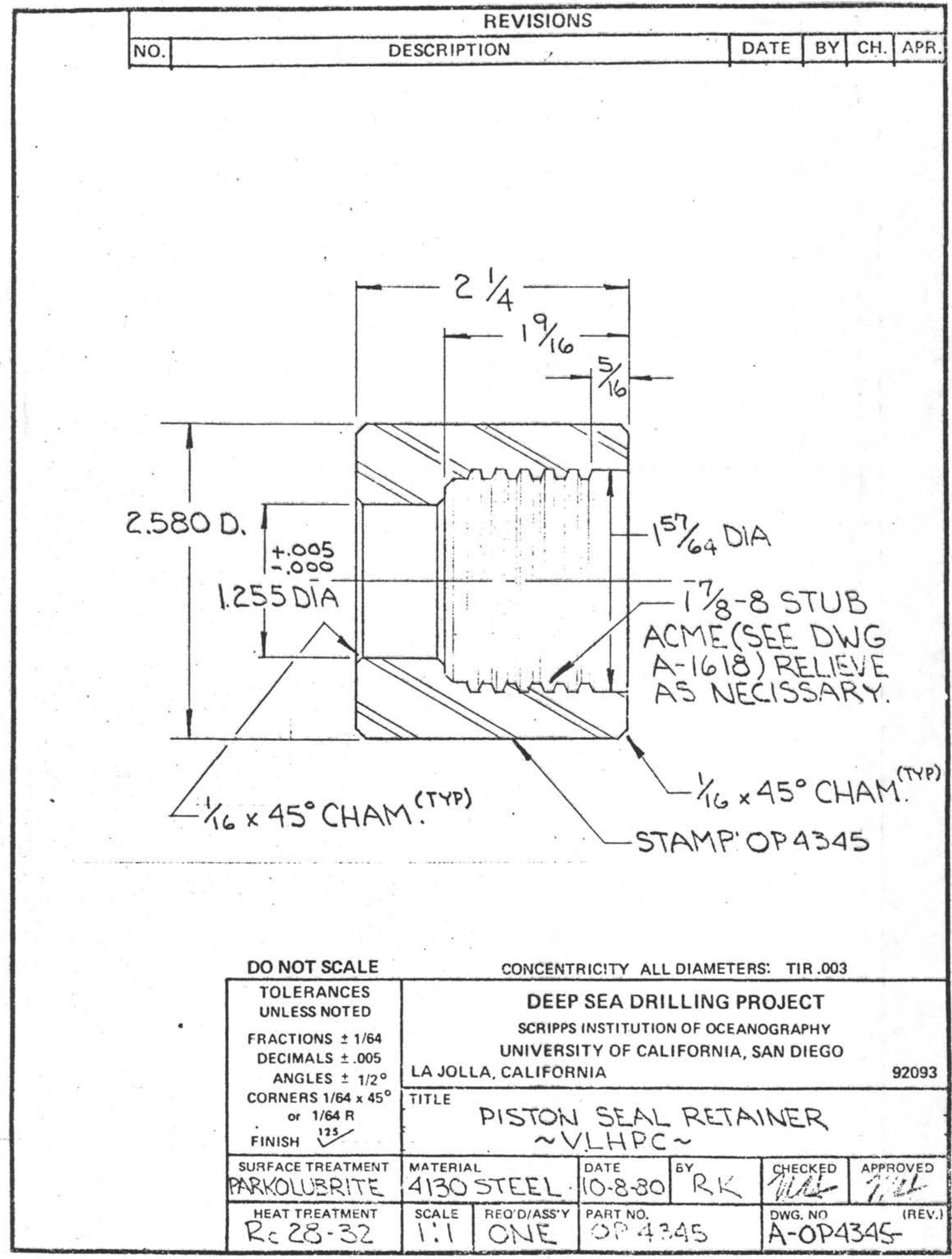

144 


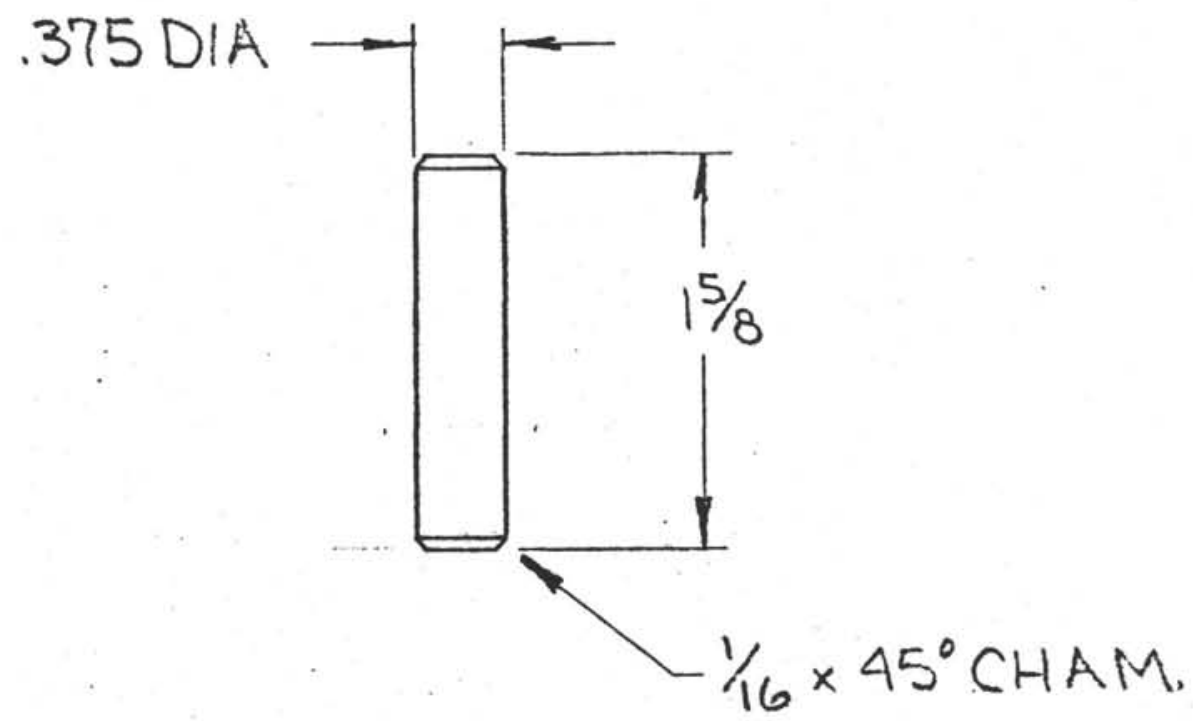

DO NOT SCALE TOLERANCES UNLESS NOTED

FRACTIONS $\pm 1 / 64$ DECIMALS \pm .005 ANGLES $\pm 1 / 2^{\circ}$ CORNERS $1 / 64 \times 45^{\circ}$ or $1 / 64 R$ FINISH 12S SURFACE TREATMENT

HEAT TREATMENT $H / 150$
CONCENTRICITY ALL DIAMETERS: TIR.003

DEEP SEA DRILLING PROJECT SCRIPPS INSTITUTION OF OCEANOGRAPHY UNIVERSITY OF CALIFORNIA, SAN DIEGO LA JOLLA, CALIFORNIA 92093 TITLE LOCK PIN - PISTON VLHPC DATE 0 BY. L. H. 3: $:$ R.K PART NOO. 1:i ONE op $4283-1$ AWG NOP $4383-1$ 


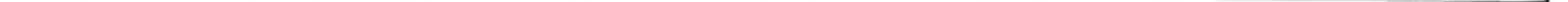




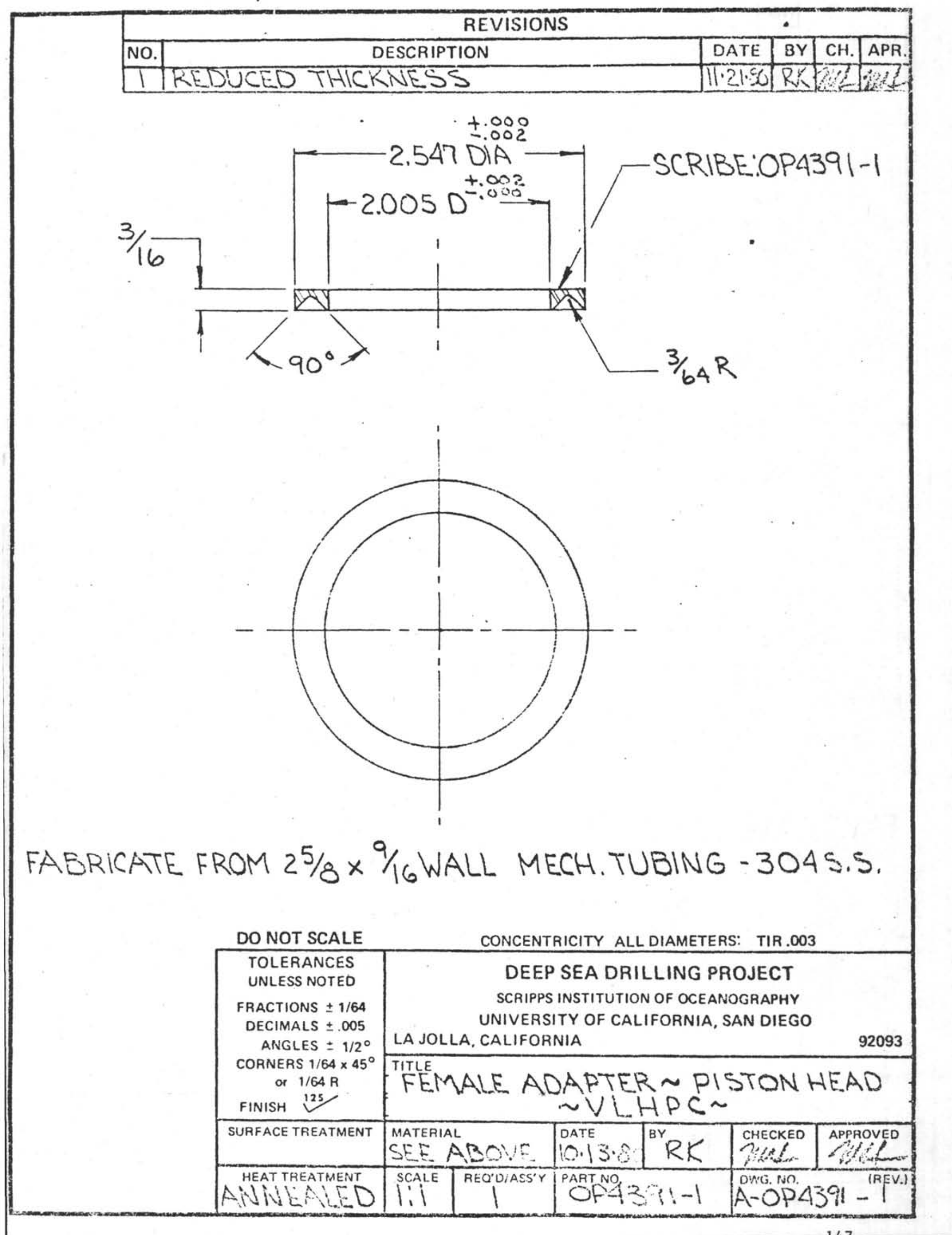




\begin{tabular}{|c|c|c|c|c|c|c|}
\hline \multicolumn{7}{|c|}{ REVISIONS } \\
\hline NO. & DESCRIPTION & . & DATE & BY & $\mathrm{CH}$. & APR. \\
\hline 1 & REVISED DESIGN & & 9.11 .00 & RK & 1:1! & hLet \\
\hline 2 & $3 / 8$ DIA TYP WAS $5 / 16,3 / 8+$ & & $2 \cdot 24 \cdot 81$ & RK & & \\
\hline
\end{tabular}

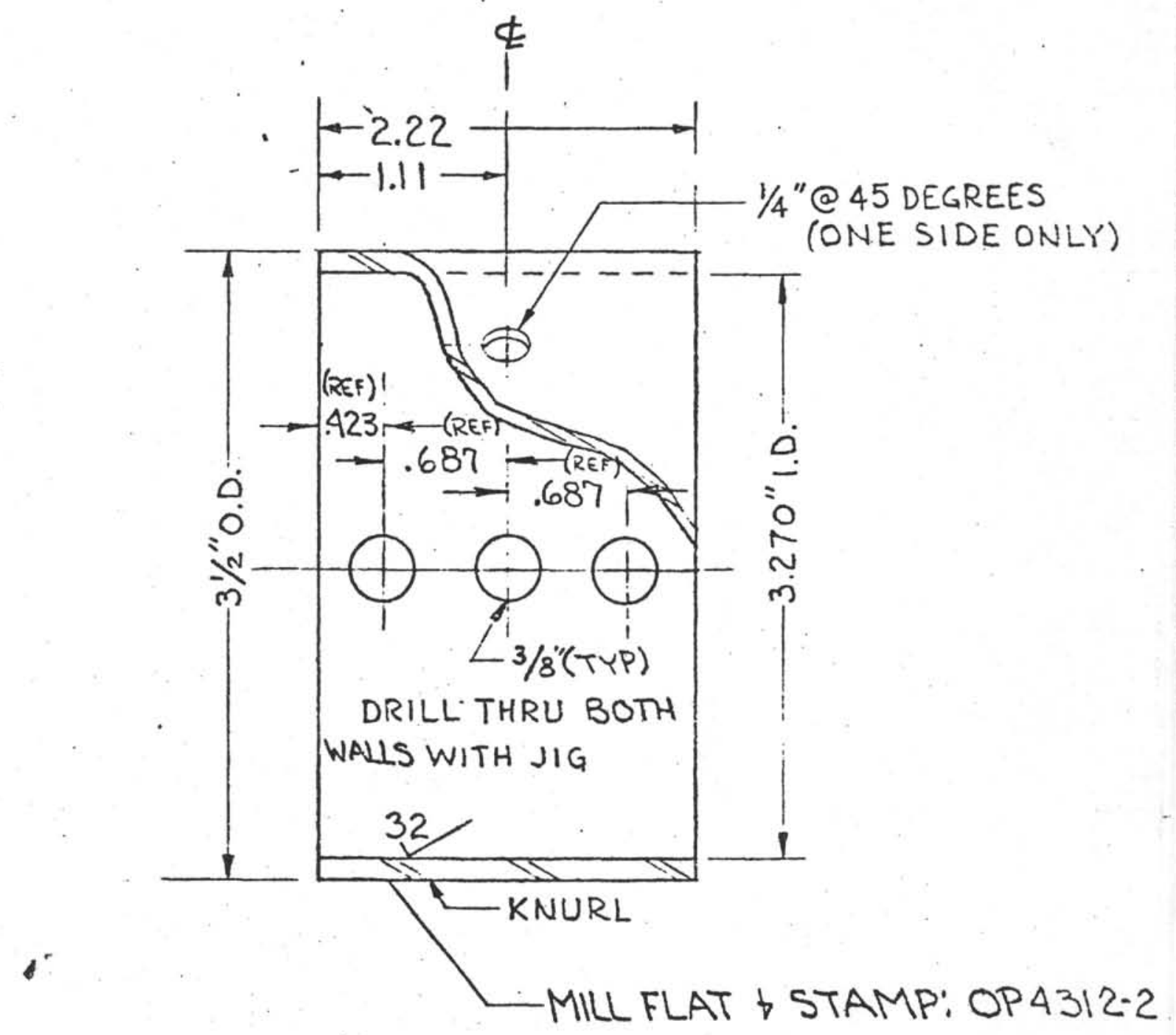

NOTE:

BREAK ALI SLIARP EDGES

FADIUS ALL INOIDE CORNERS

\begin{tabular}{|c|c|c|c|c|c|c|}
\hline \multirow{2}{*}{$\begin{array}{l}\text { TOLERANCES } \\
\text { UNLESS NOTED } \\
\text { FRACTIONS } \pm 1 / 64 \\
\text { DECIMALS } \pm .005 \\
\text { ANGLES } \pm 1 / 2^{\circ} \\
\text { CORNERS } 1 / 64 \times 45^{\circ} \\
\text { or } 1 / 64 R \\
\text { FINISH } 125 \\
\end{array}$} & \multicolumn{5}{|c|}{$\begin{array}{l}\text { DEEP SEA DRILLING PROJECT } \\
\text { SCRIPPS INSTITUTION OF OCEANOGRAPHY } \\
\text { UNIVERSITY OF CALIFORNIA, SAN DIEGO } \\
\text { LA JOLLA, CALIFORNIA }\end{array}$} & 92093 \\
\hline & THTLE & \multicolumn{4}{|c|}{$\begin{array}{l}\text { SLEEVE-OUTER BODY CAP } \\
\text { YLHPC }\end{array}$} & \\
\hline $\begin{array}{l}\text { SURFACE TREATMENT } \\
\text { PARKO LUREITE }\end{array}$ & WATERIAL & 4130 C.D. & DRAIVN BY & $\begin{array}{c}\text { DATEE } \\
\rightarrow / 2 / 30\end{array}$ & CHECKED & AriROVED \\
\hline $\begin{array}{l}\text { HEAT TFEATMENT } \\
\text { RC-30-32 }\end{array}$ & $\begin{array}{r}\text { PAPT NO: } \\
\text { O: }\end{array}$ & $4: 12-2$ & $\begin{array}{l}\text { SIZE DWG } \\
A-C T\end{array}$ & NOS3! & $2-$ & $\begin{array}{l}\text { REV } \\
?\end{array}$ \\
\hline
\end{tabular}


$\pm: 002$

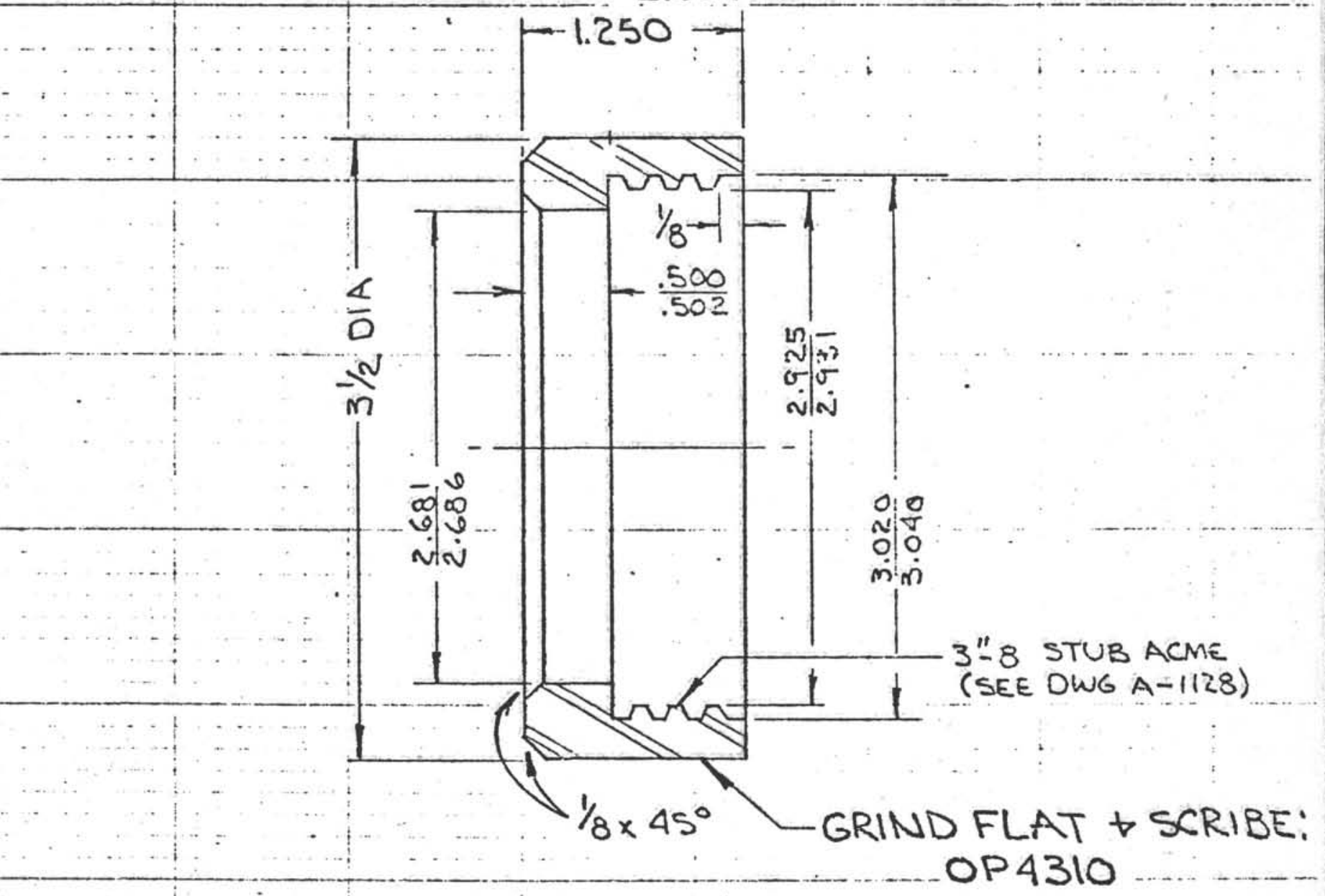

CONCENTRICITY:

ALL DIAMETERS :R. 002

\section{NOYES}

BREAK ALI SHARP EDGES

RADUUS ALL INSIDE CORNERS
- TOLERANCES UNLESS NOTED

FRACTIONS $\pm 1 / 64$ DECIMALS \pm .005 ANGLES $\pm 1 / 2^{\circ}$ CORNERS $1 / 64 \times 45^{\circ}$ or $1 / 64 R$ FINISH 125 SURFACE TREATMENT PAESCLUBRITE. HEAT TREATMENT $R(2,0-3 ?$

\begin{tabular}{|c|c|c|c|c|}
\hline $\begin{array}{r}\text { DEEP SEA } \\
\text { SCRIPPS INSTI } \\
\text { UNIVERSITY O } \\
\text { LA JOLLA. CALIFORNIA }\end{array}$ & $\begin{array}{l}\text { DRILLIN } \\
\text { UTION OFO } \\
\text { CALIFORI }\end{array}$ & $\begin{array}{l}\text { G PRO } \\
\text { CEANOC } \\
\text { NIA, SA }\end{array}$ & $\begin{array}{l}\text { JECT } \\
\text { SRAPHY } \\
\text { N DIEGO }\end{array}$ & 92093 \\
\hline $\begin{array}{r}\text { RETAHNER } \\
\text { VL }\end{array}$ & $\begin{array}{l}\text { RING OL } \\
\text { HPC }\end{array}$ & TEF. & BODY & $C A D$ \\
\hline IAATERIAL 4130 C.D. & $\begin{array}{l}\text { DRAWN BY } \\
\because !\end{array}$ & $\begin{array}{l}\text { DATE } \\
? / 121=8\end{array}$ & $\begin{array}{c}\text { CHECKED } \\
\text { LNS }\end{array}$ & APPROVED \\
\hline $\begin{array}{l}\text { PARTNO } \\
\text { OPA }\end{array}$ & $\begin{array}{l}\text { SIZE DWG. } \\
A-O \dot{P}\end{array}$ & 43 & $0-$ & $\begin{array}{l}\text { REV. } \\
\text { O }\end{array}$ \\
\hline
\end{tabular}

DEEP SEA DRILLING PROJECT UNIVERSITY OF CALIFORNIA, SAN DIEGO LA JOLLA, CALIFORNIA 2093

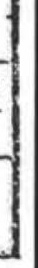




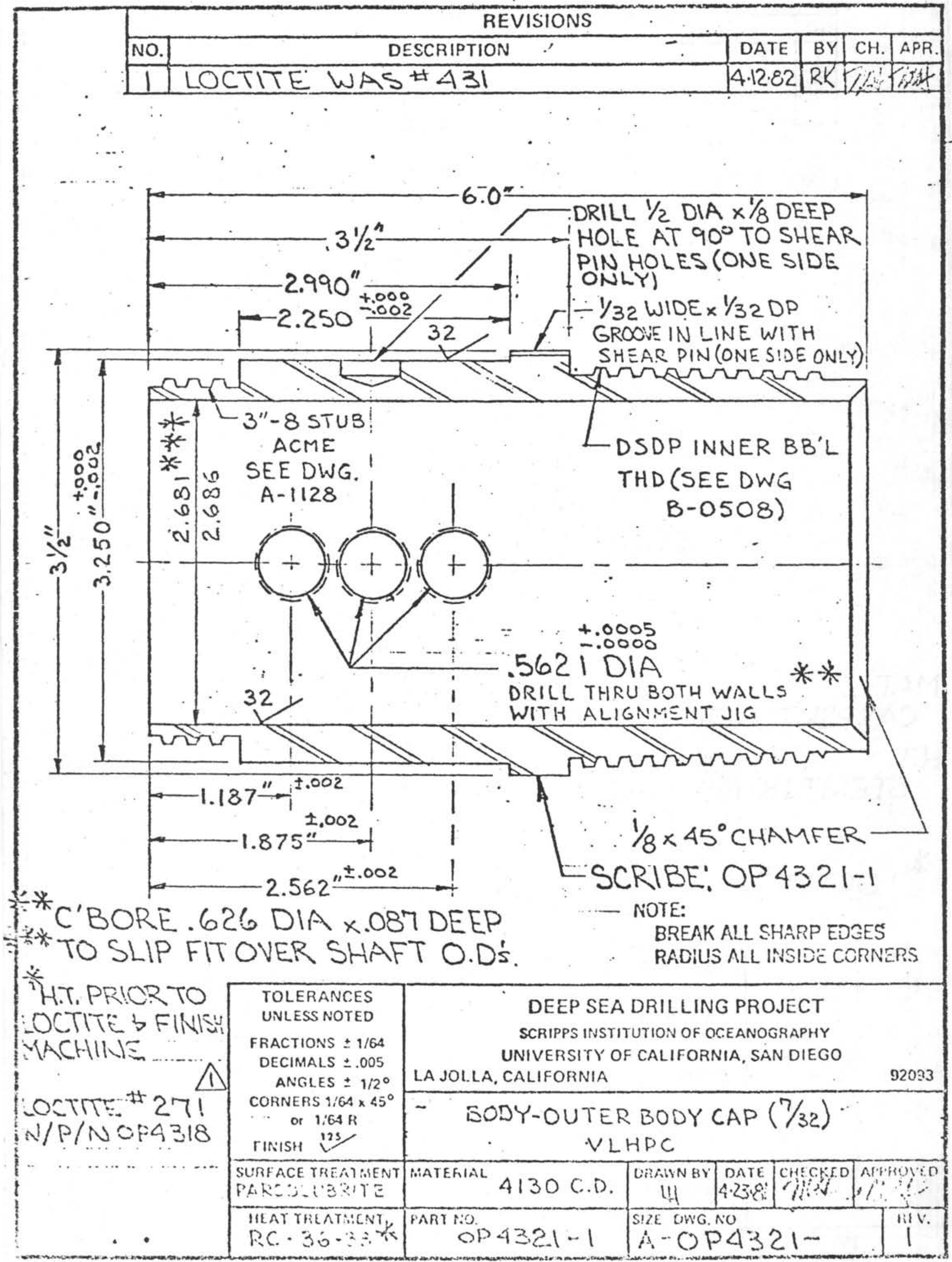




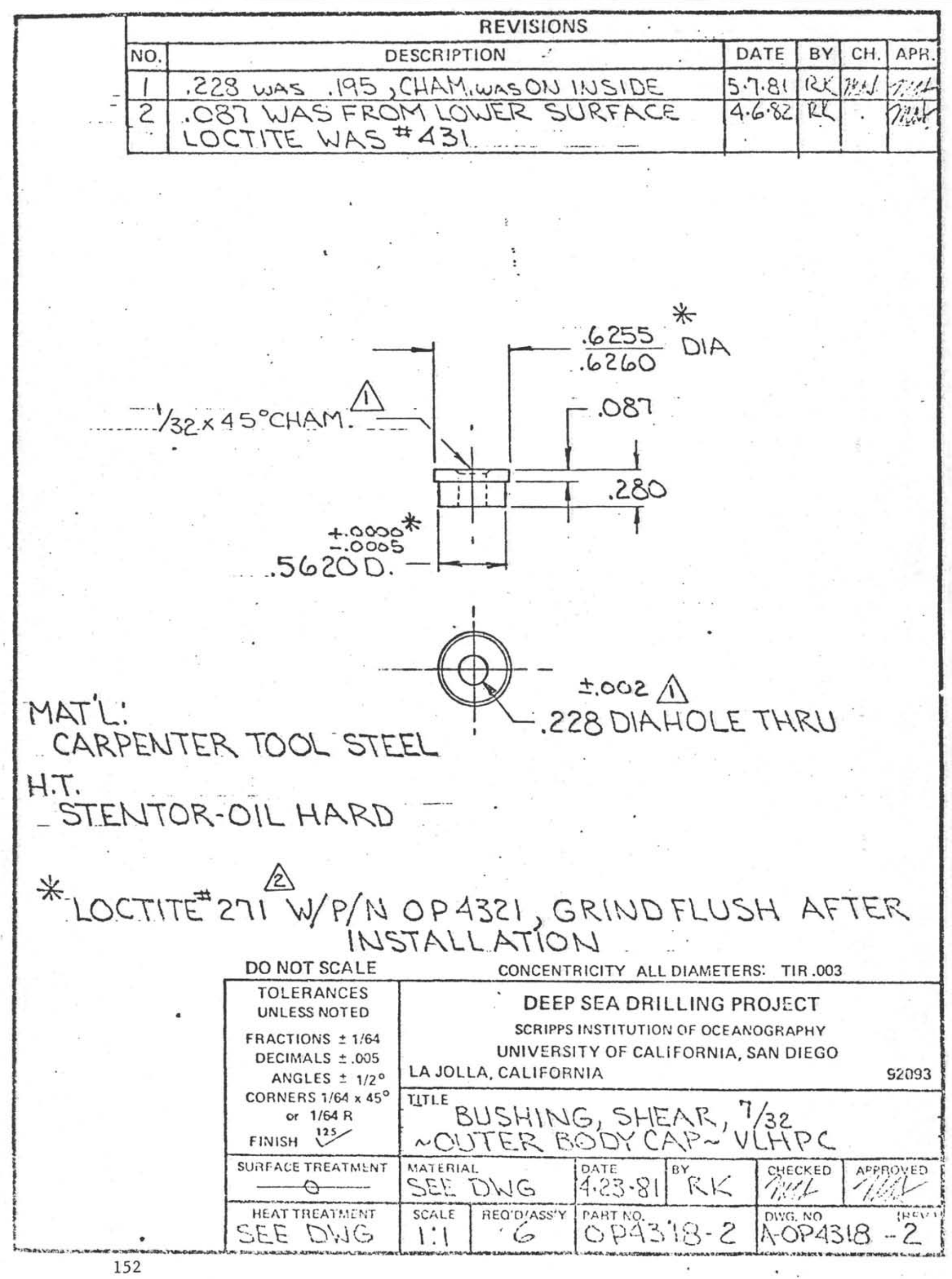




\begin{tabular}{|c|c|c|c|c|c|}
\hline NO. & DESCRIPTION & DATE & BY & CH. & APR. \\
\hline 1 & WAS: 3/16 DIA, & & 5.7 .81 & RY & \% \\
\hline
\end{tabular}

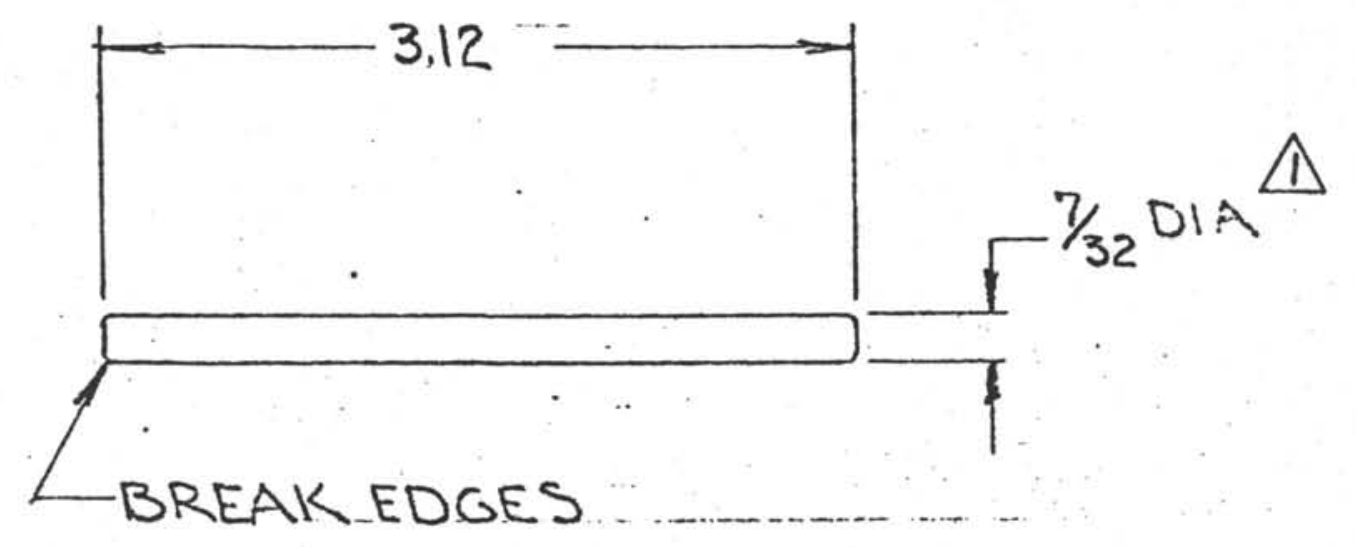

MAT'L:

1018 C.R. STEEL, TENSILE. 85,000 PSI, YIELD 70,000 PSI ALT. MAT'L:

.12L14 LEADLOY A, TENSILE 78,000 PSI, YIELD 70,000 PSI NOTE:

- PINS ARE IN DOUBLE SHEAR.

DO NOT SCALE

TOLERANCES

UNLESS NOTED

FRACTIONS $\pm 1 / 64$

DECIMALS \pm .005

ANGLES $\pm 1 / 2^{\circ}$

CORNERS $1 / 64 \times 45^{\circ}$

or $1 / 64 R$

FINISH 125

SUBFACE TREATMENT

- -

HEAT TREATMIENT

Q

CONCENTRICITY ALL DIAMETERS: TIR.003

- DEEP SEA DRILLINGG PROJECT

- SCRIPPS INSTITUTION OF OCEANOGRAPHY

UNIVERSITY OF CALIFORNIA, SAN DIEGO

LA JOLLA, CALIFORNIA

92093

\begin{tabular}{|c|c|c|c|c|c|}
\hline TITLE & $7 / 325$ & $\angle H P C$ & NM & $\ldots$. & \\
\hline $\begin{array}{l}\text { MATER! } \\
\text { SEE }\end{array}$ & ROUE. & 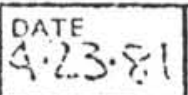 & ${ }^{8 Y} R K^{\prime}$ & CHECKED & APP+RUYED \\
\hline
\end{tabular}




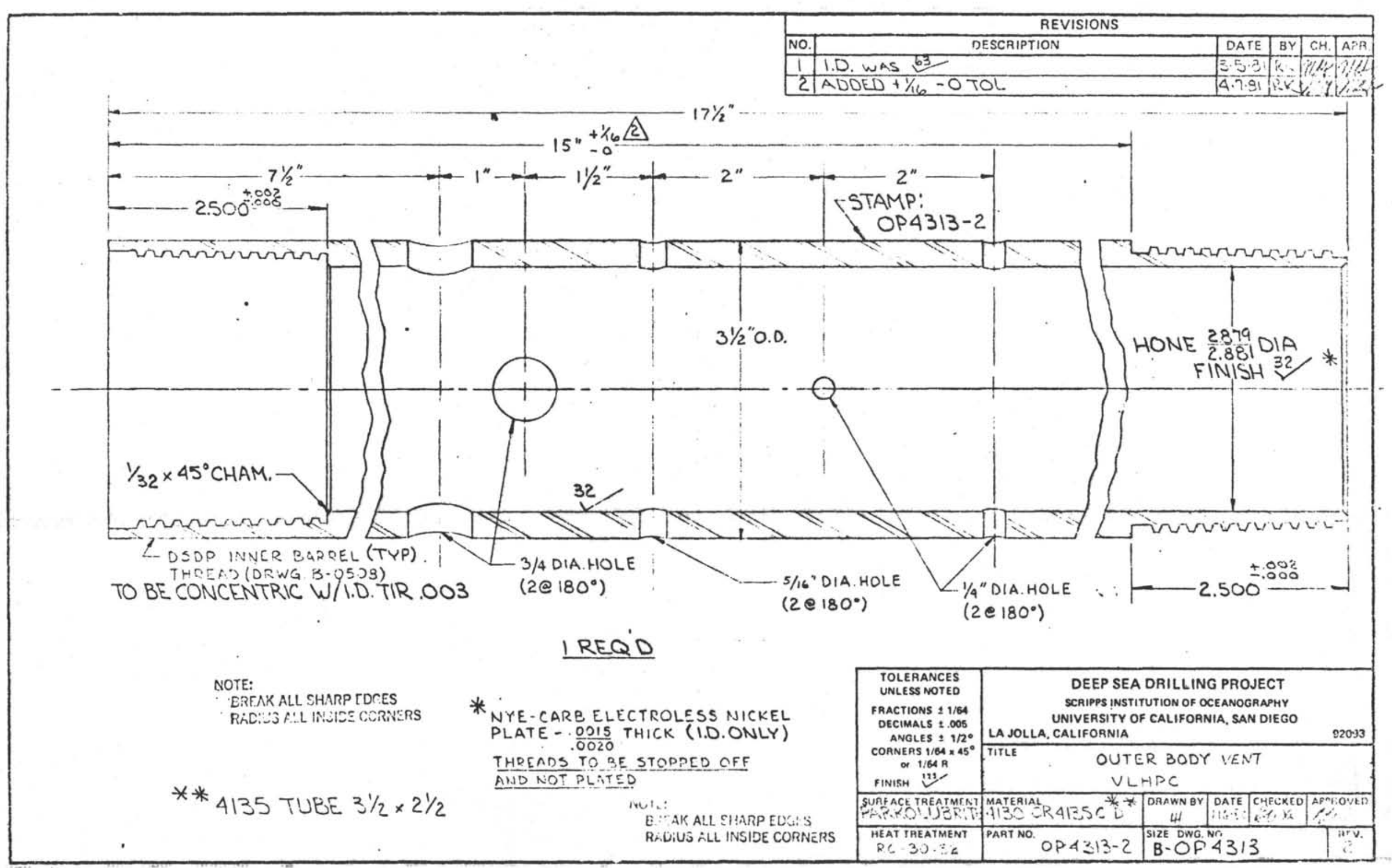




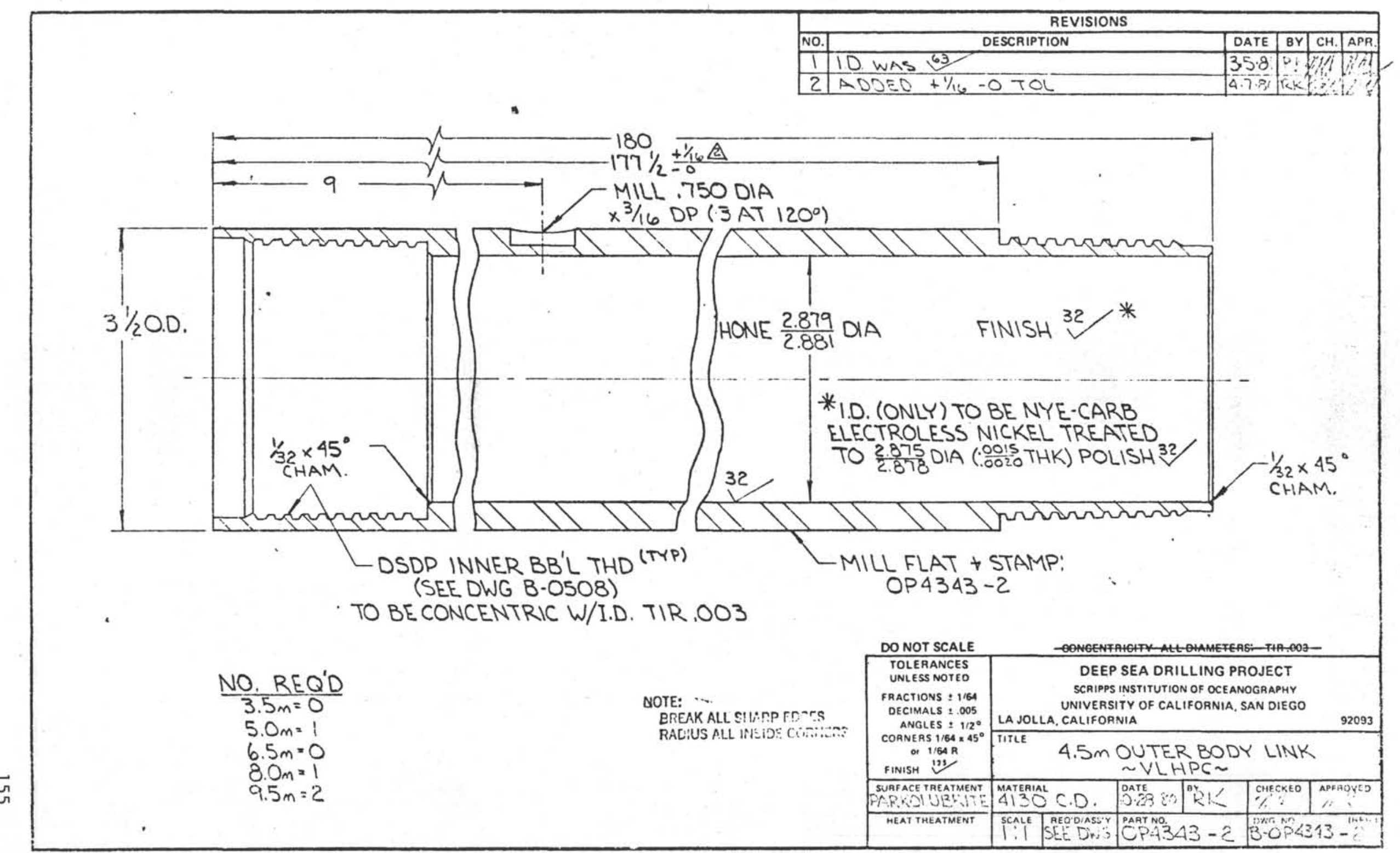




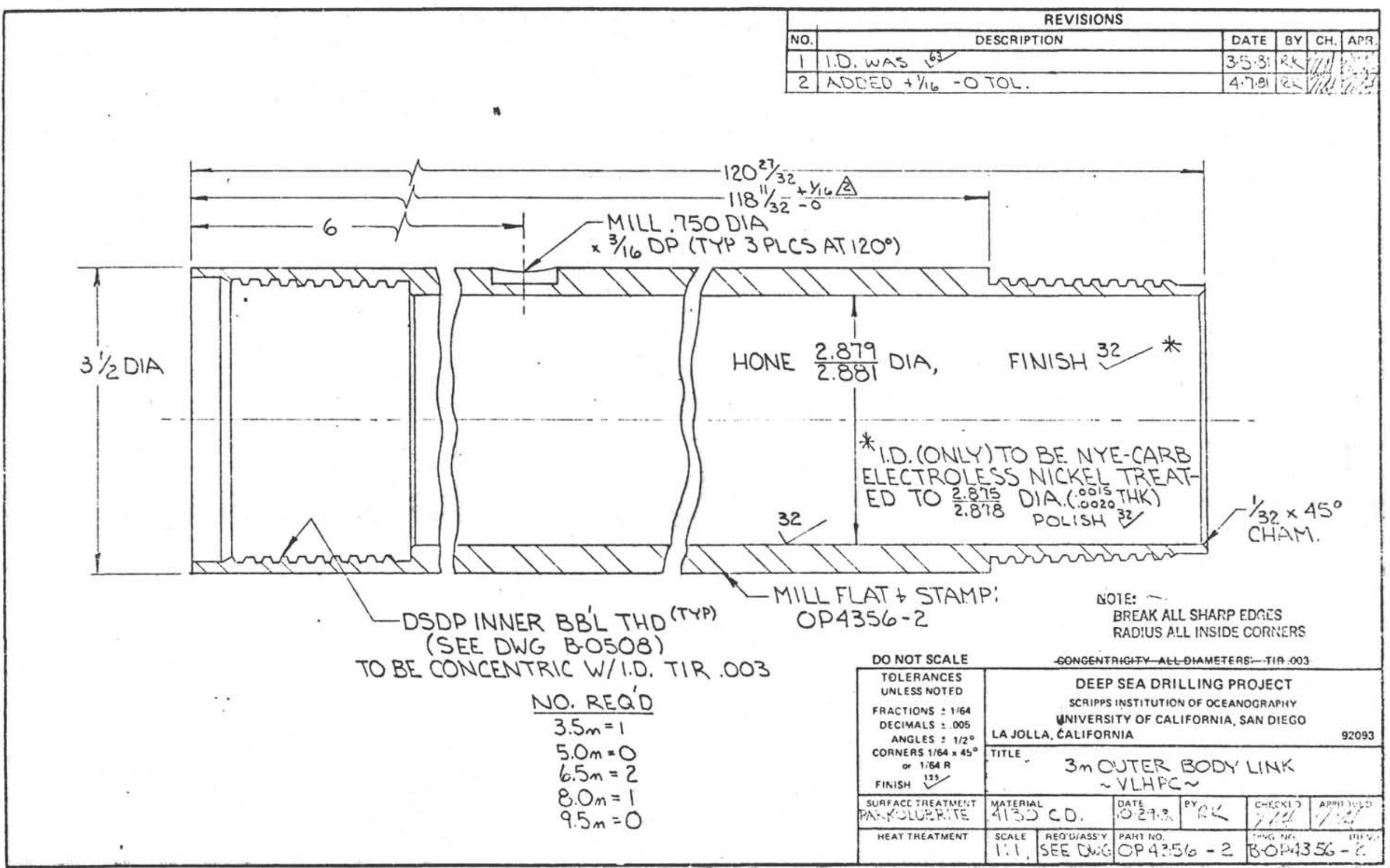




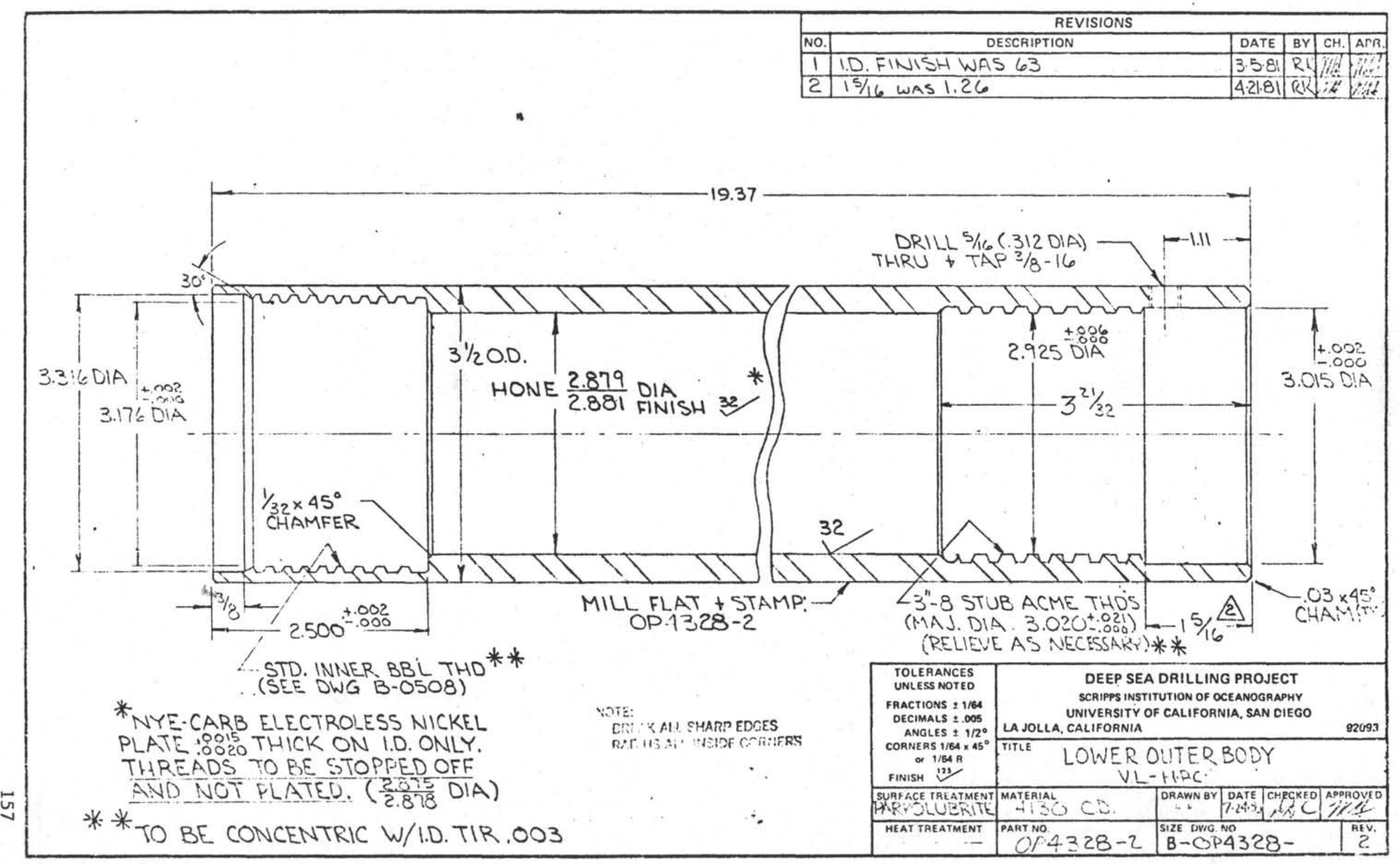




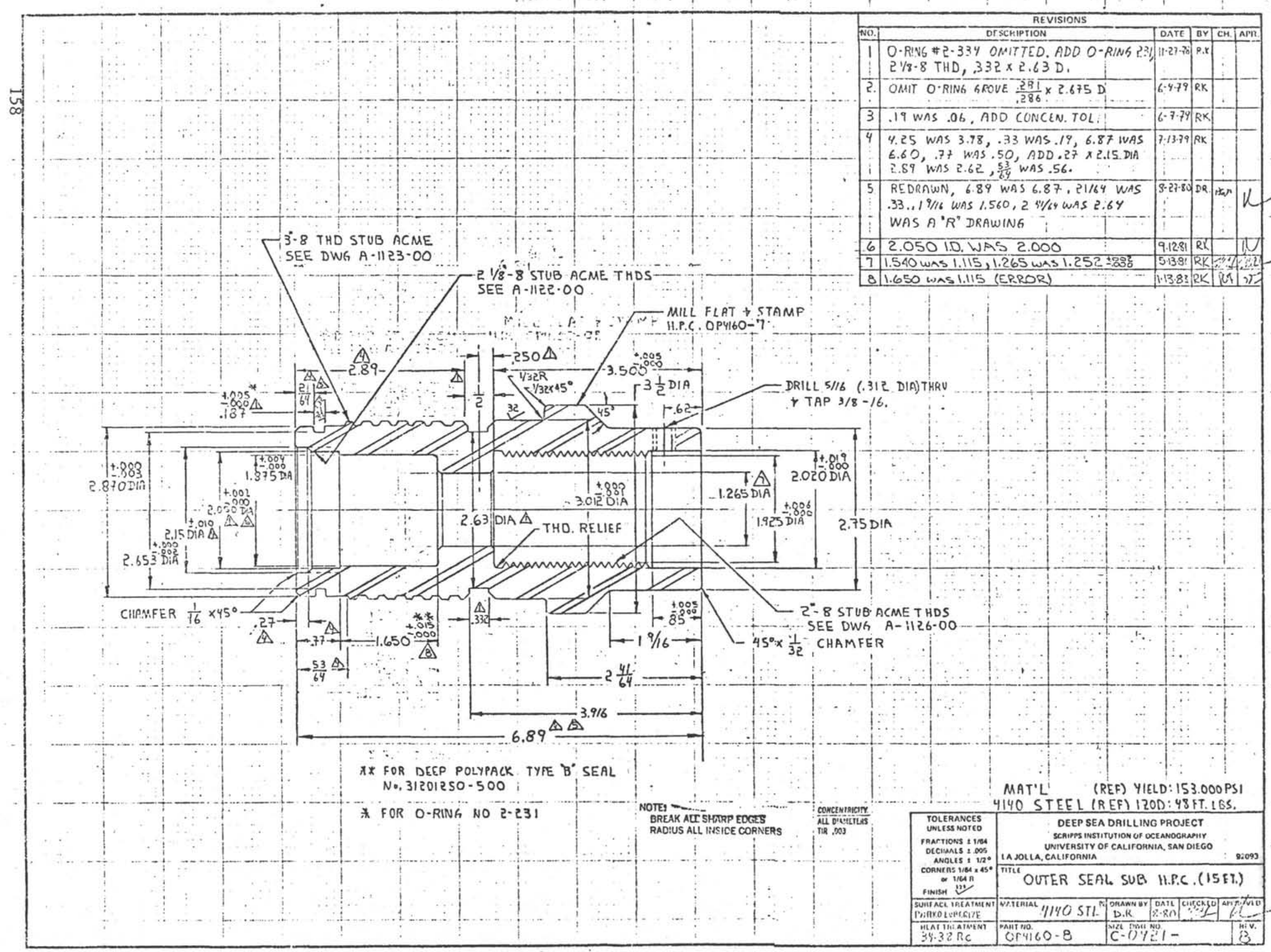




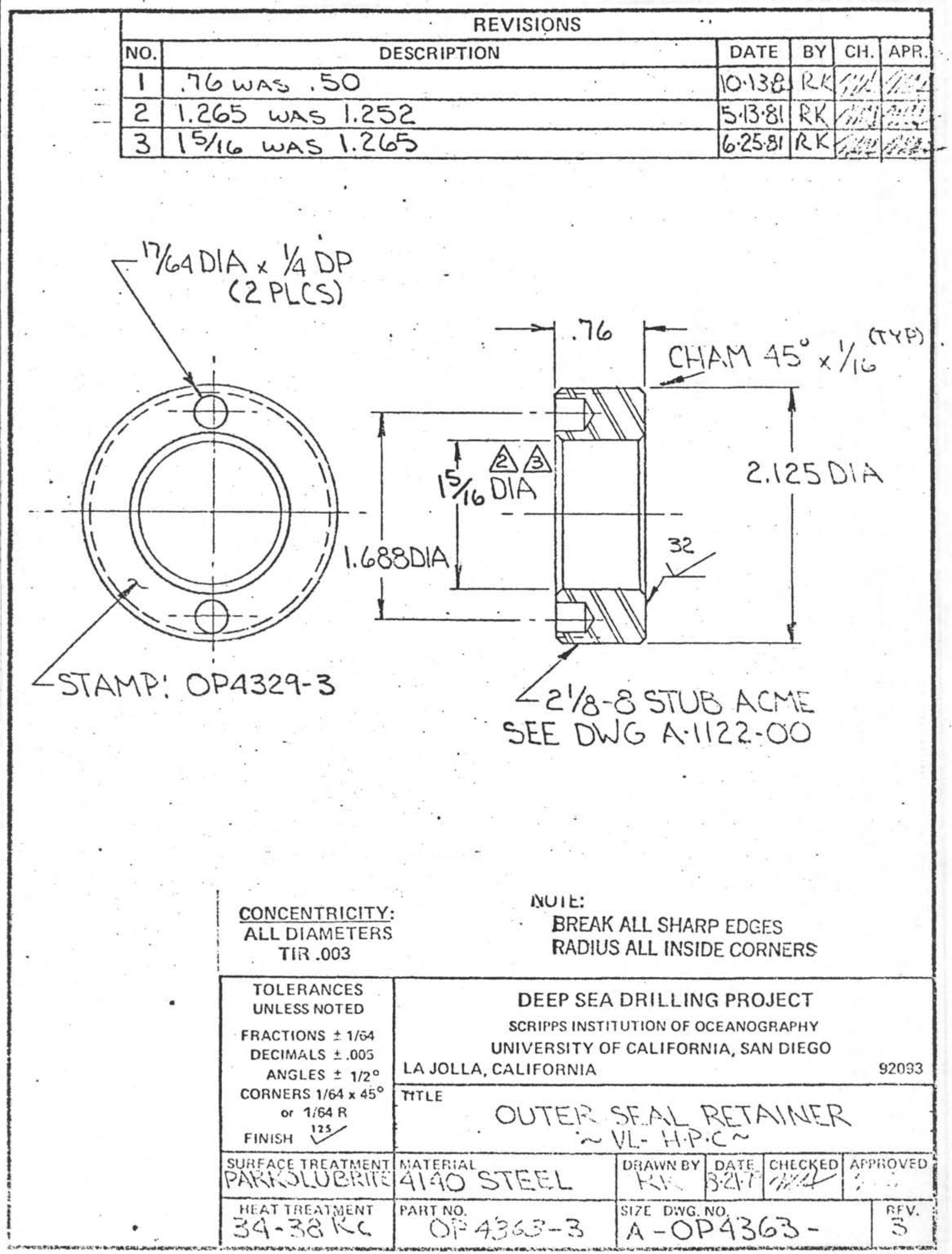




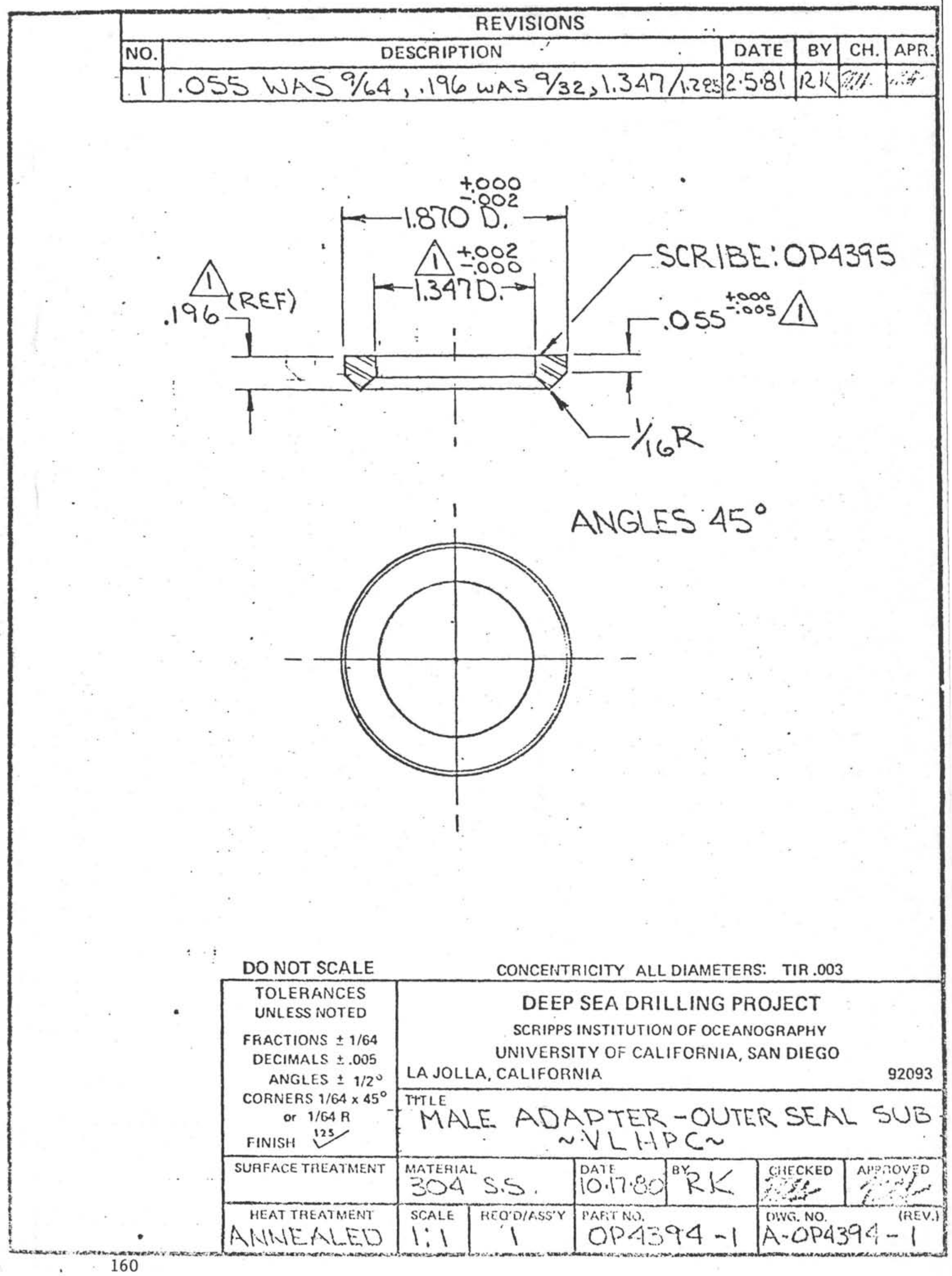




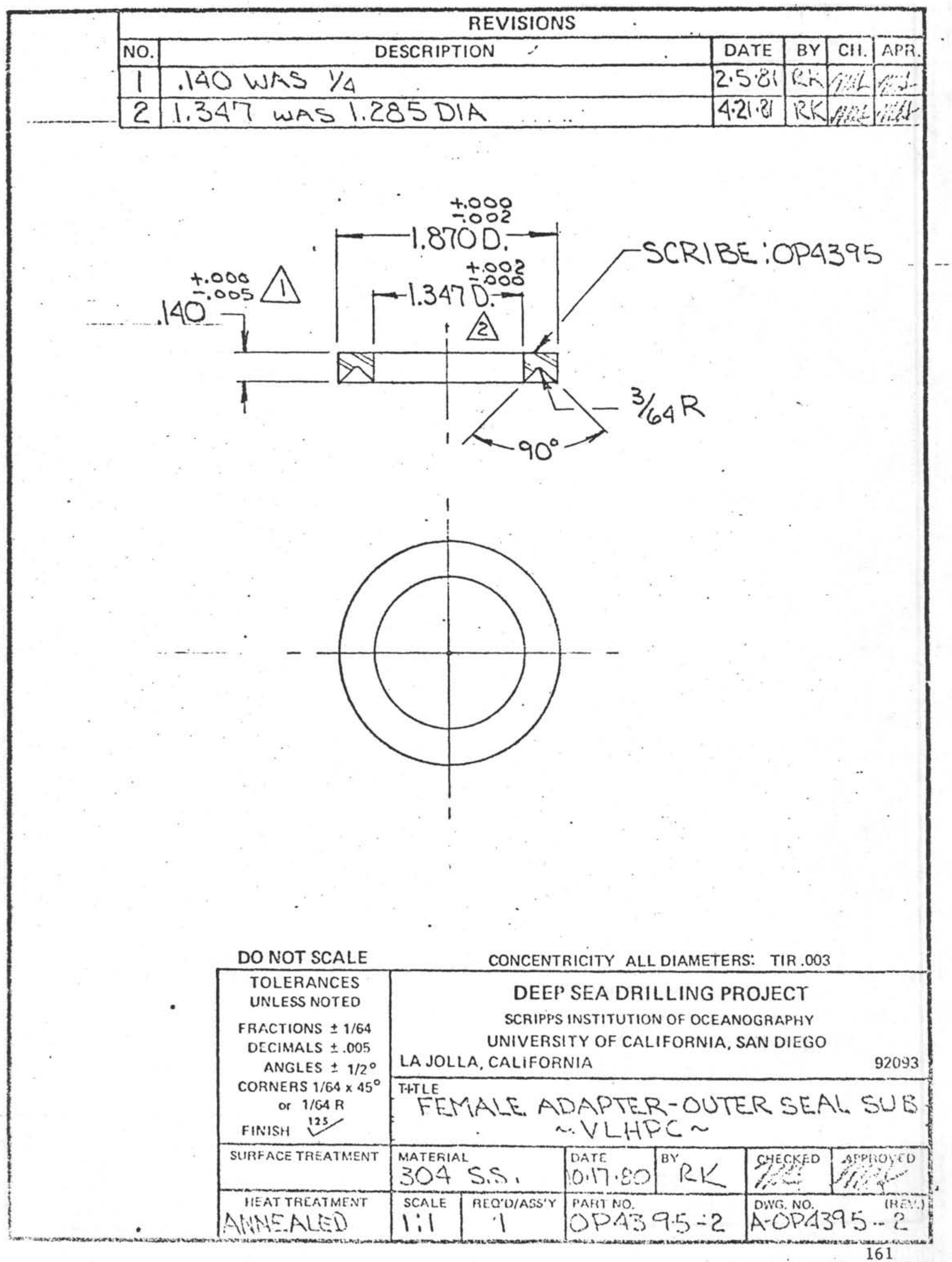




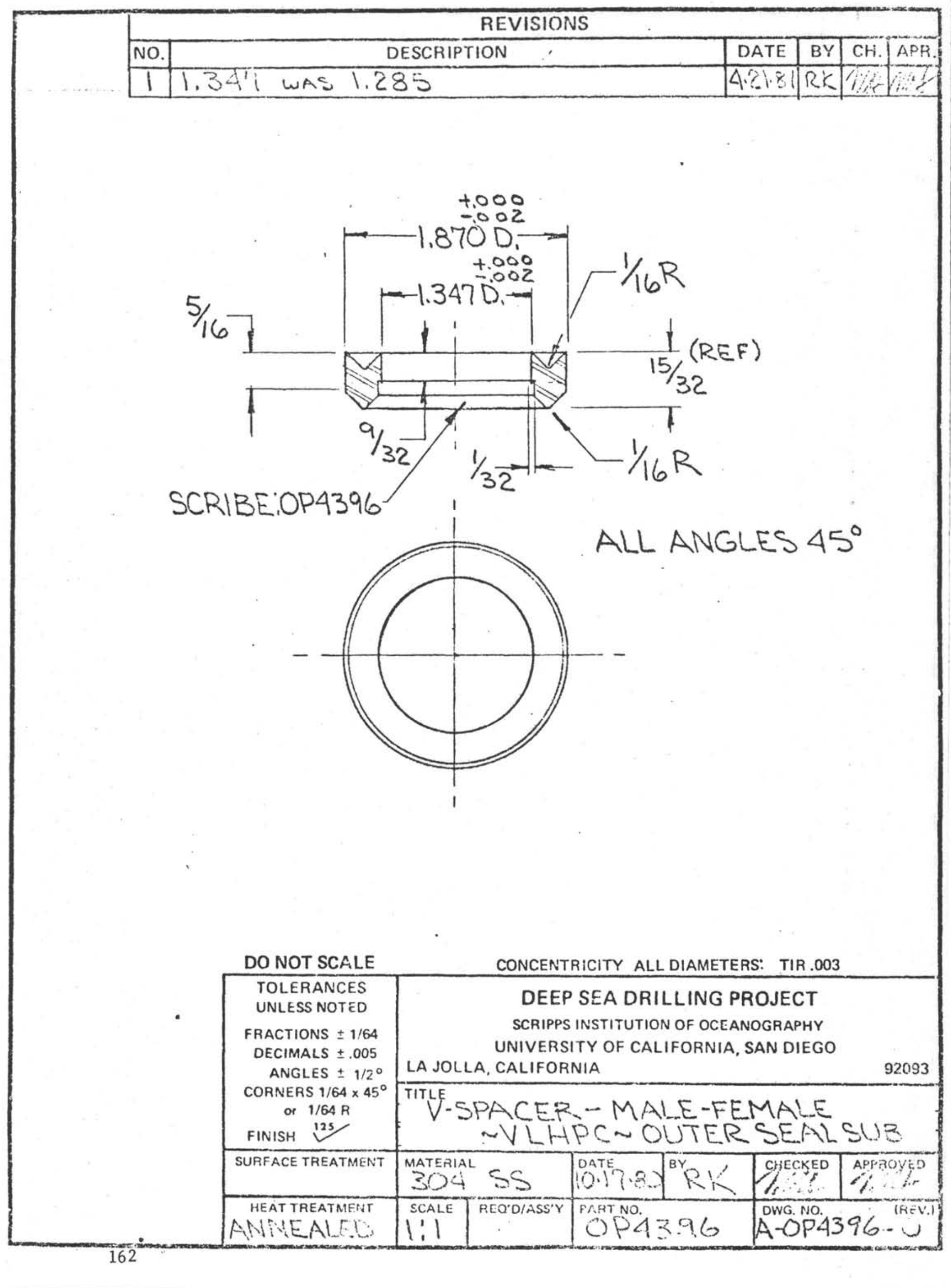




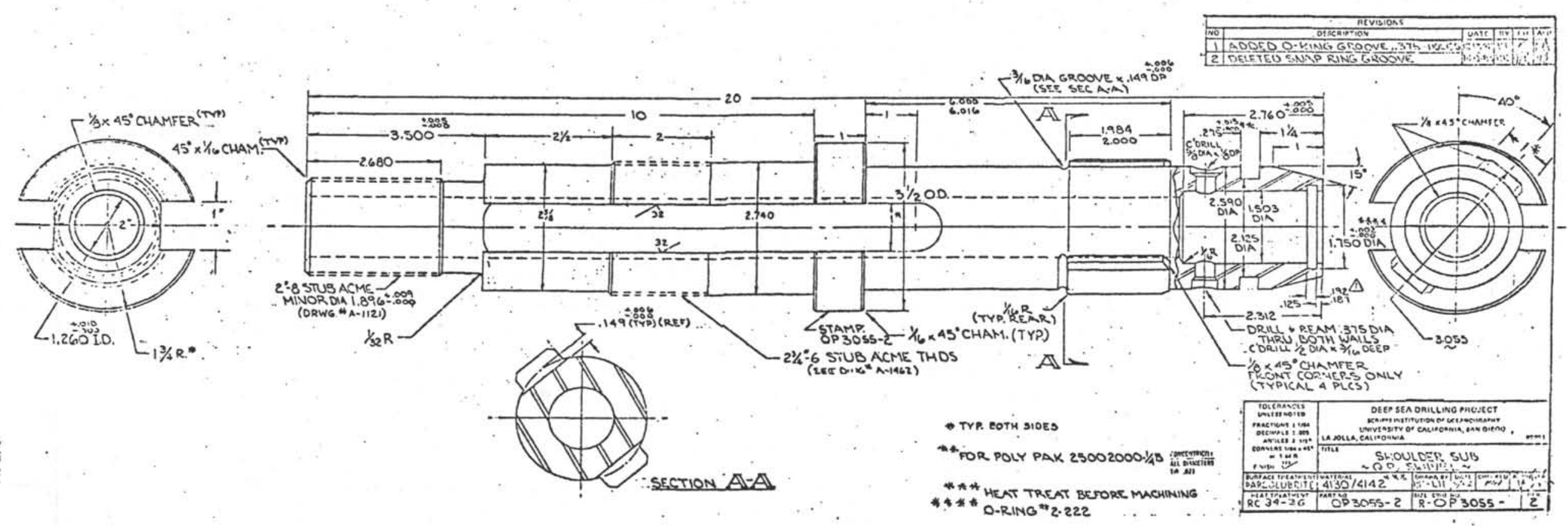




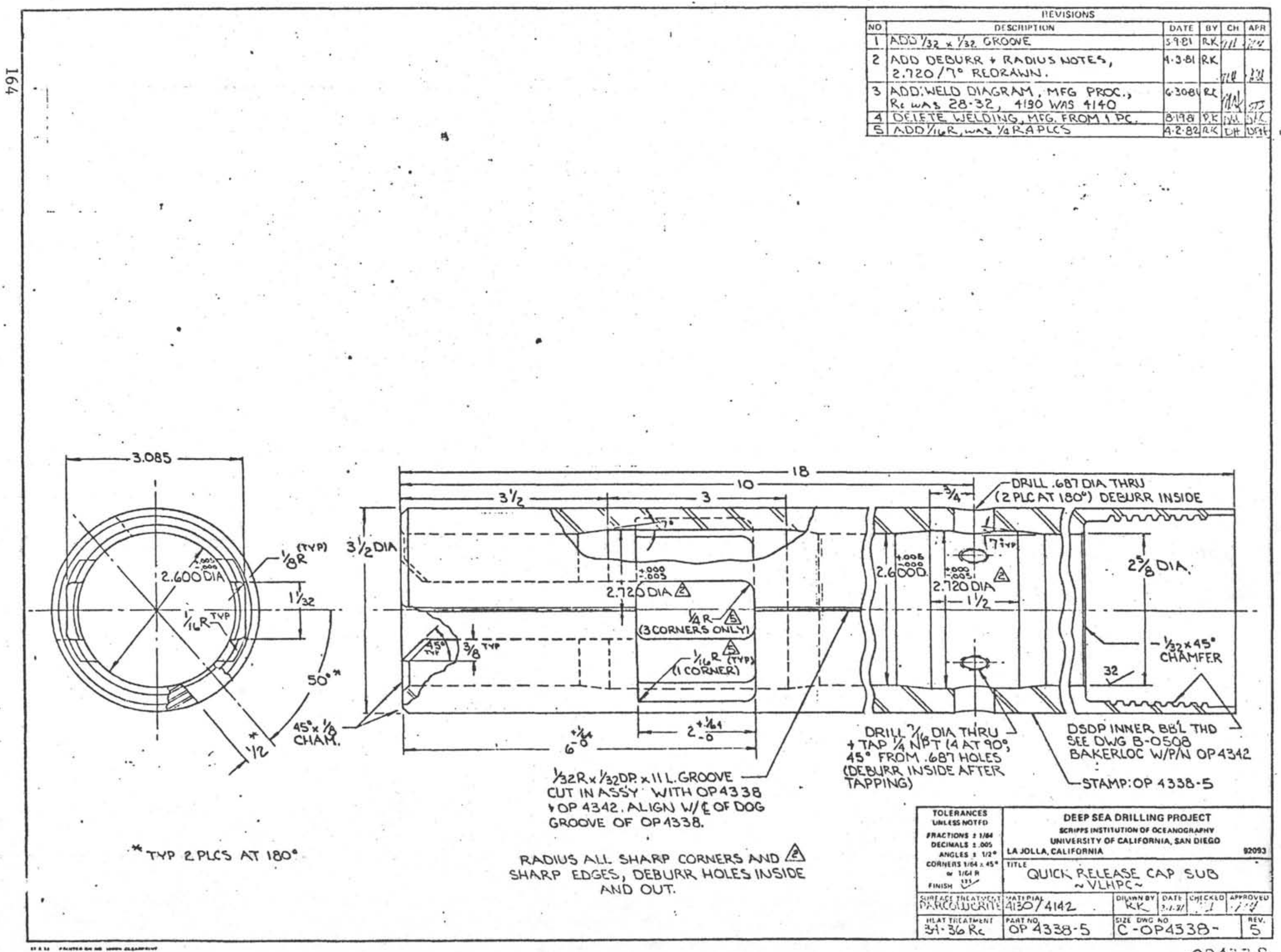




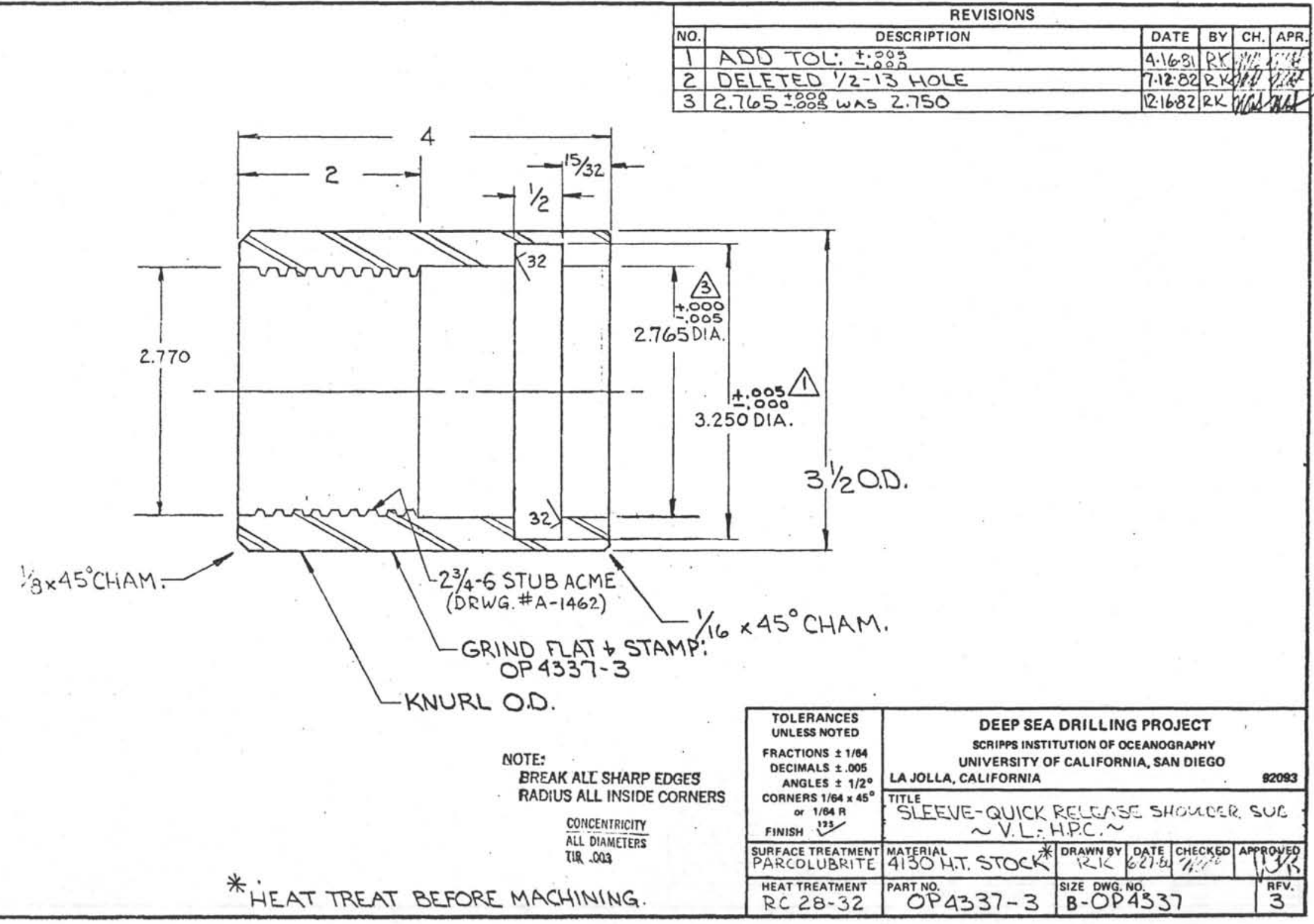




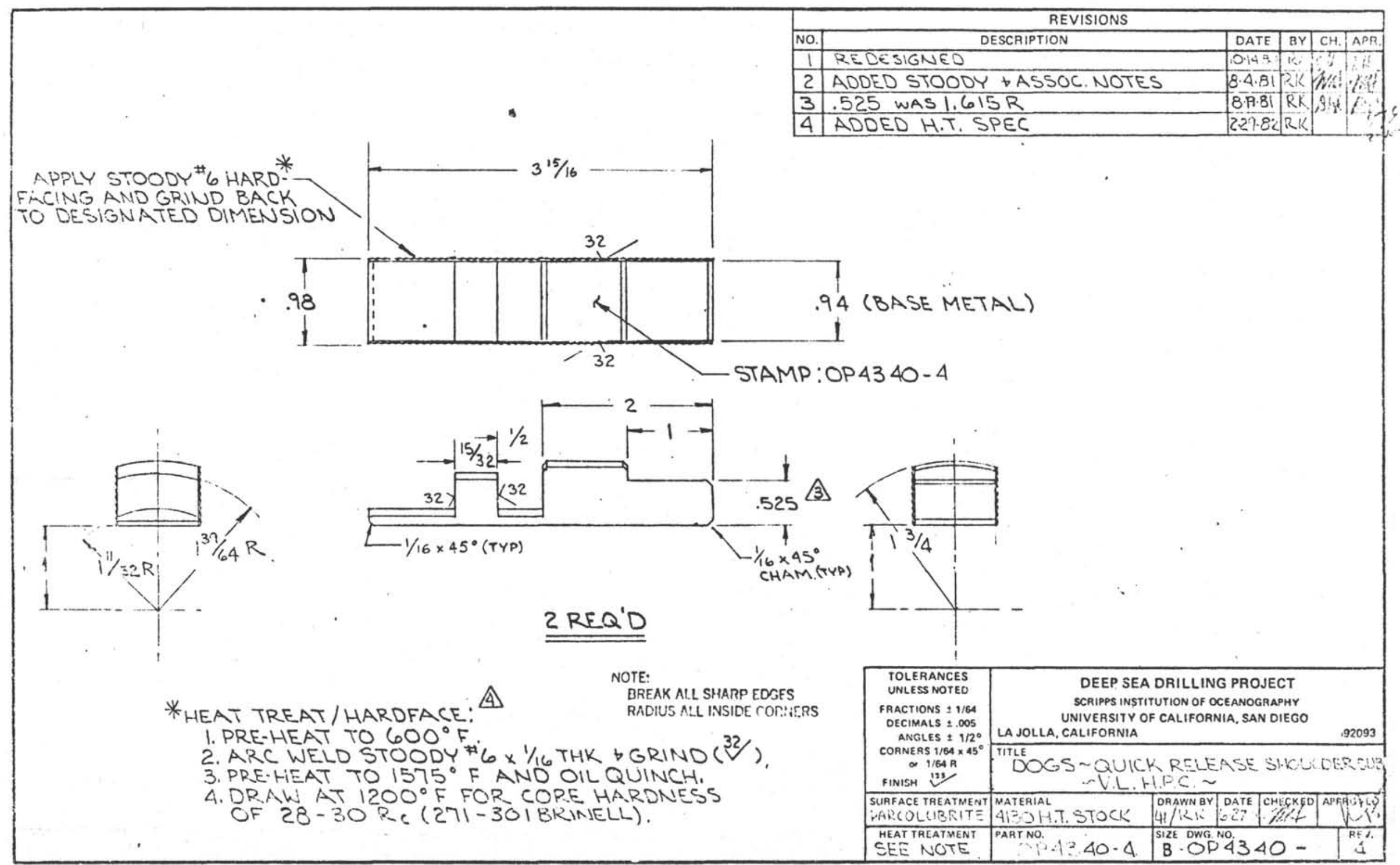




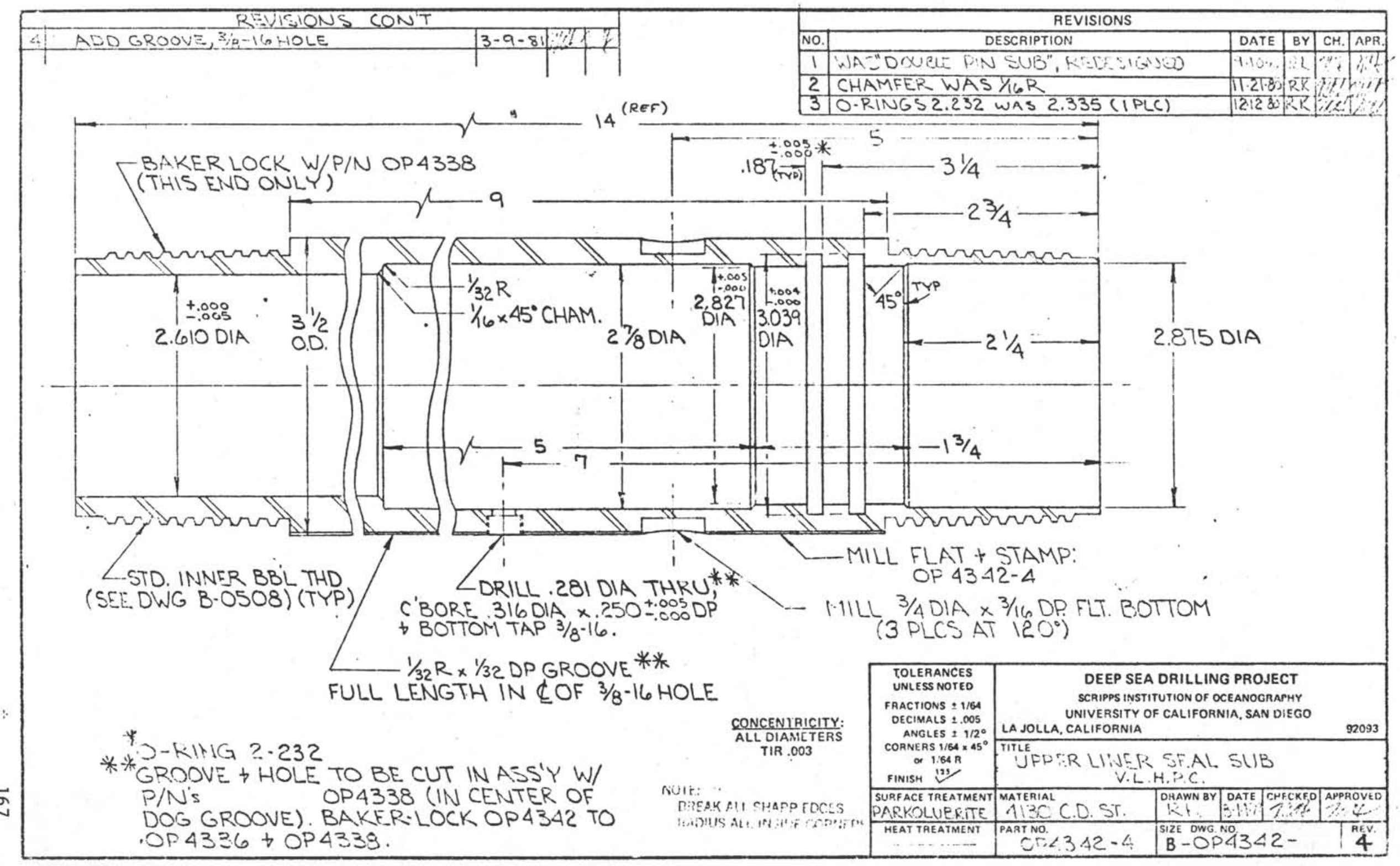




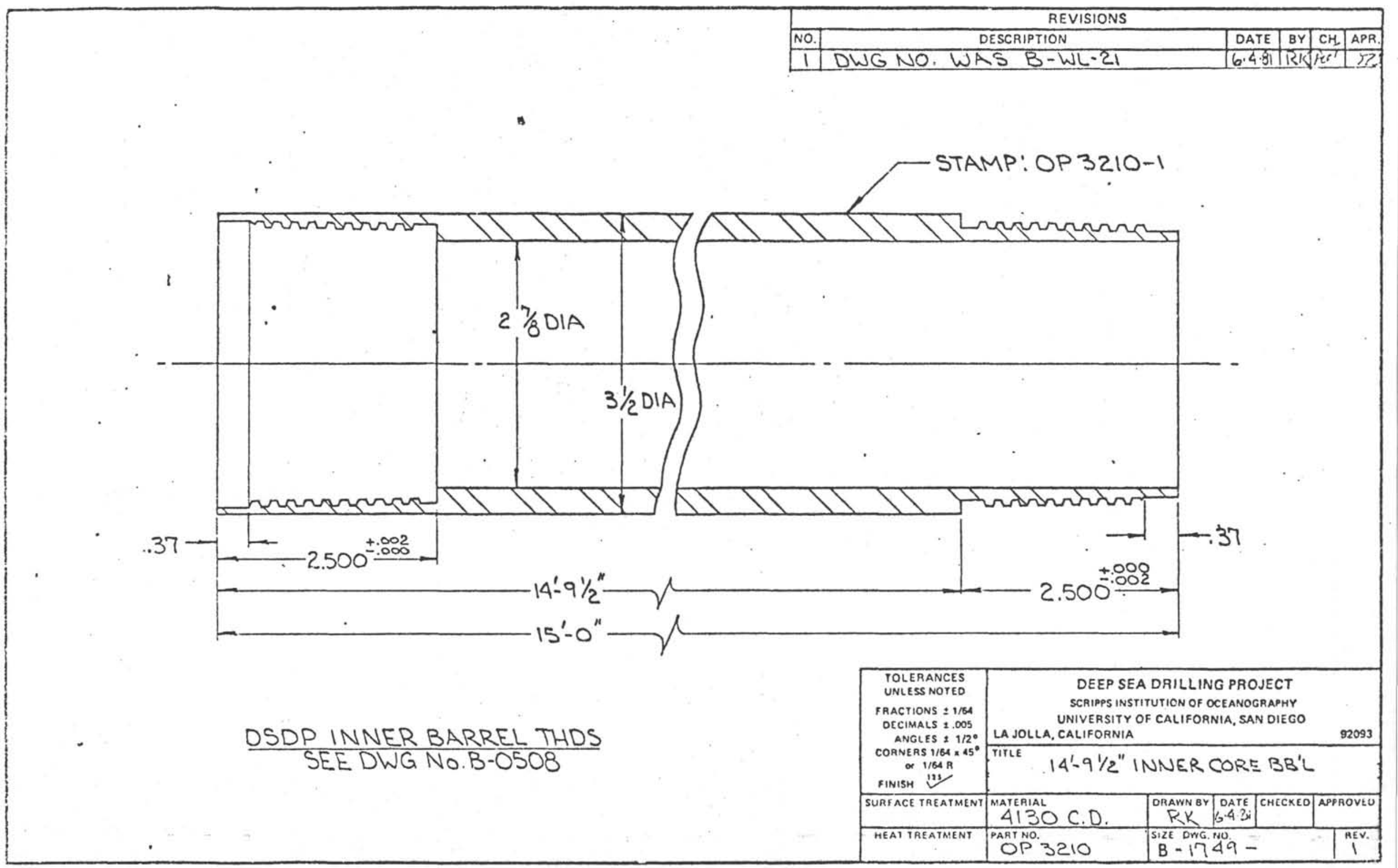




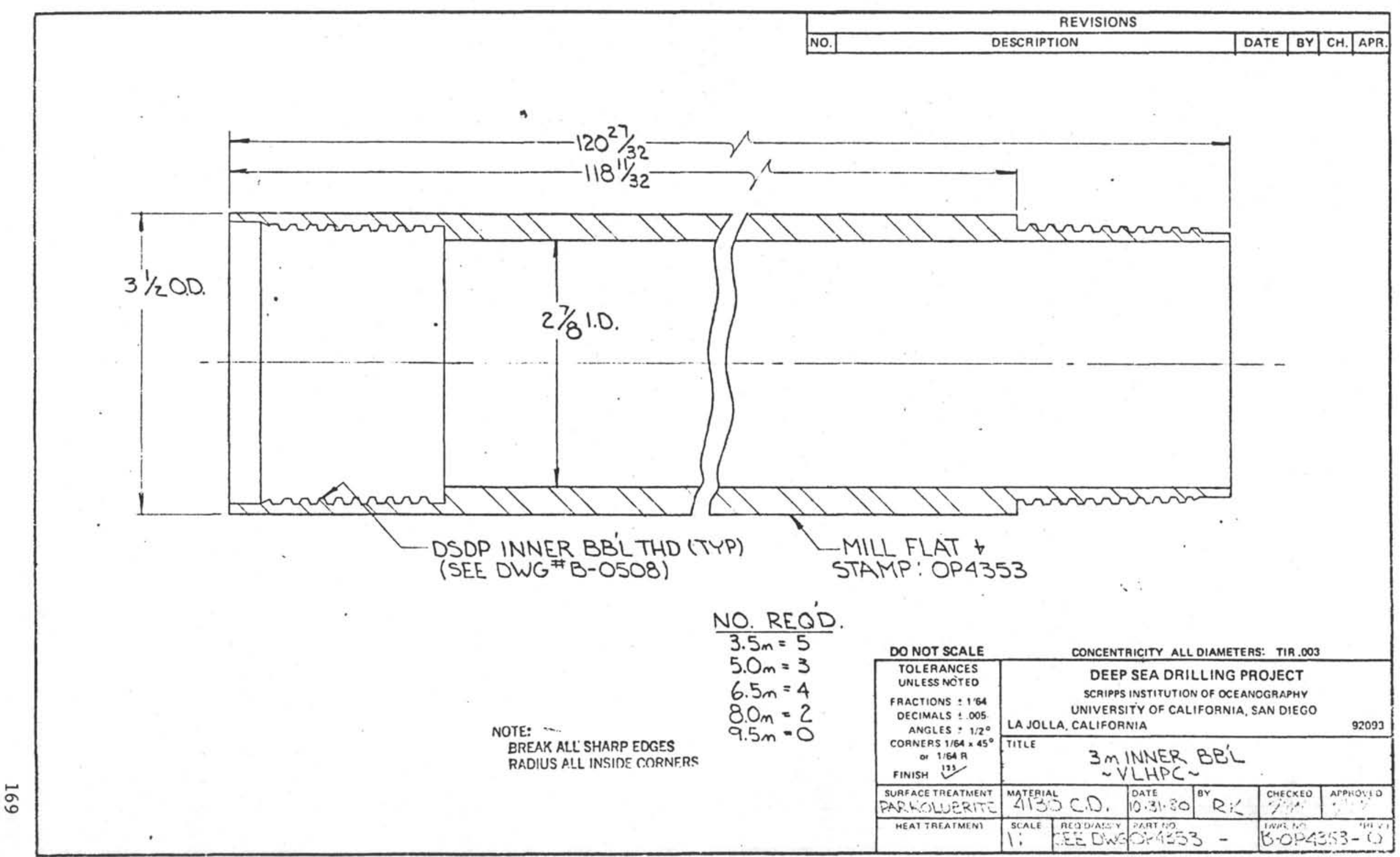




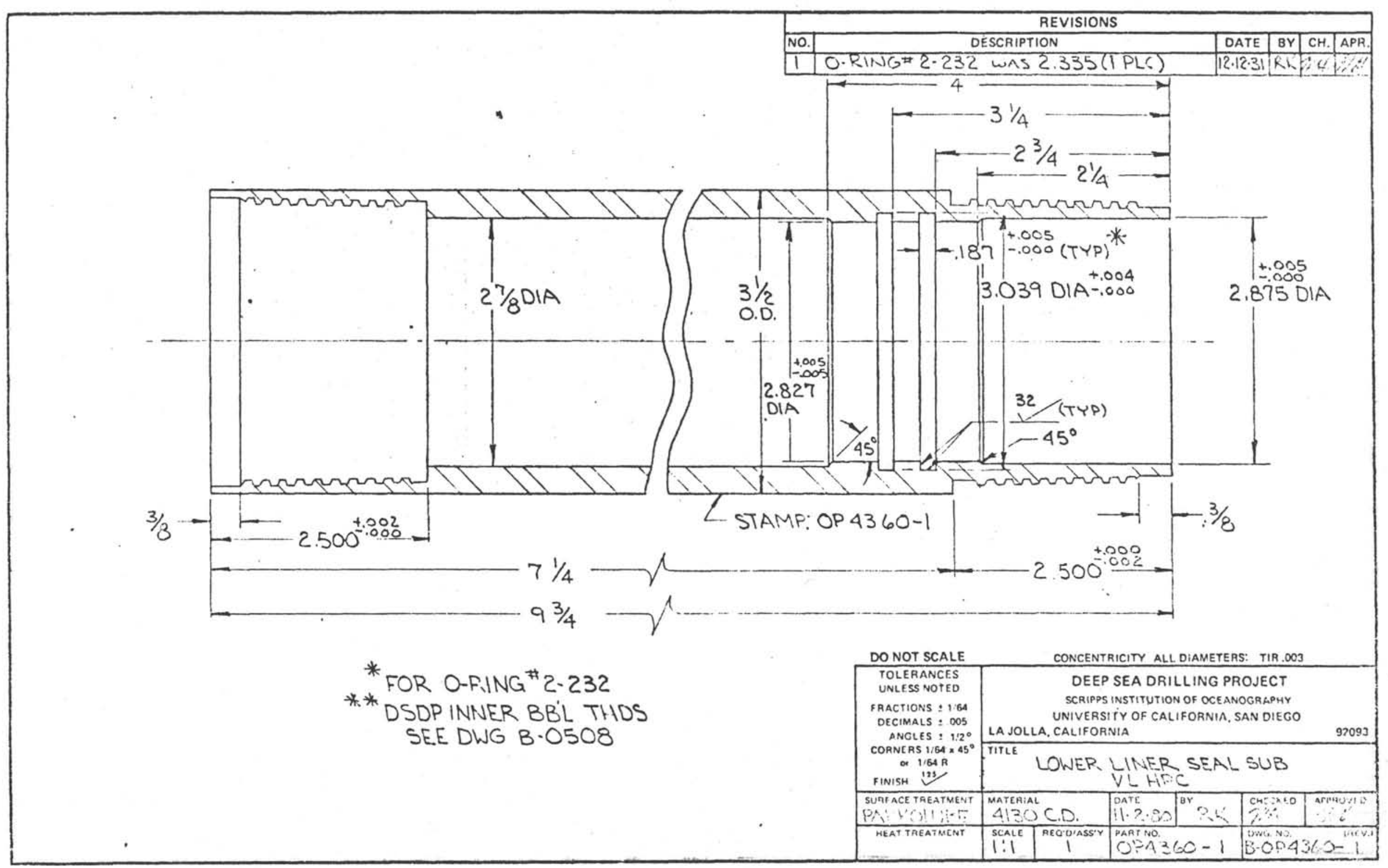




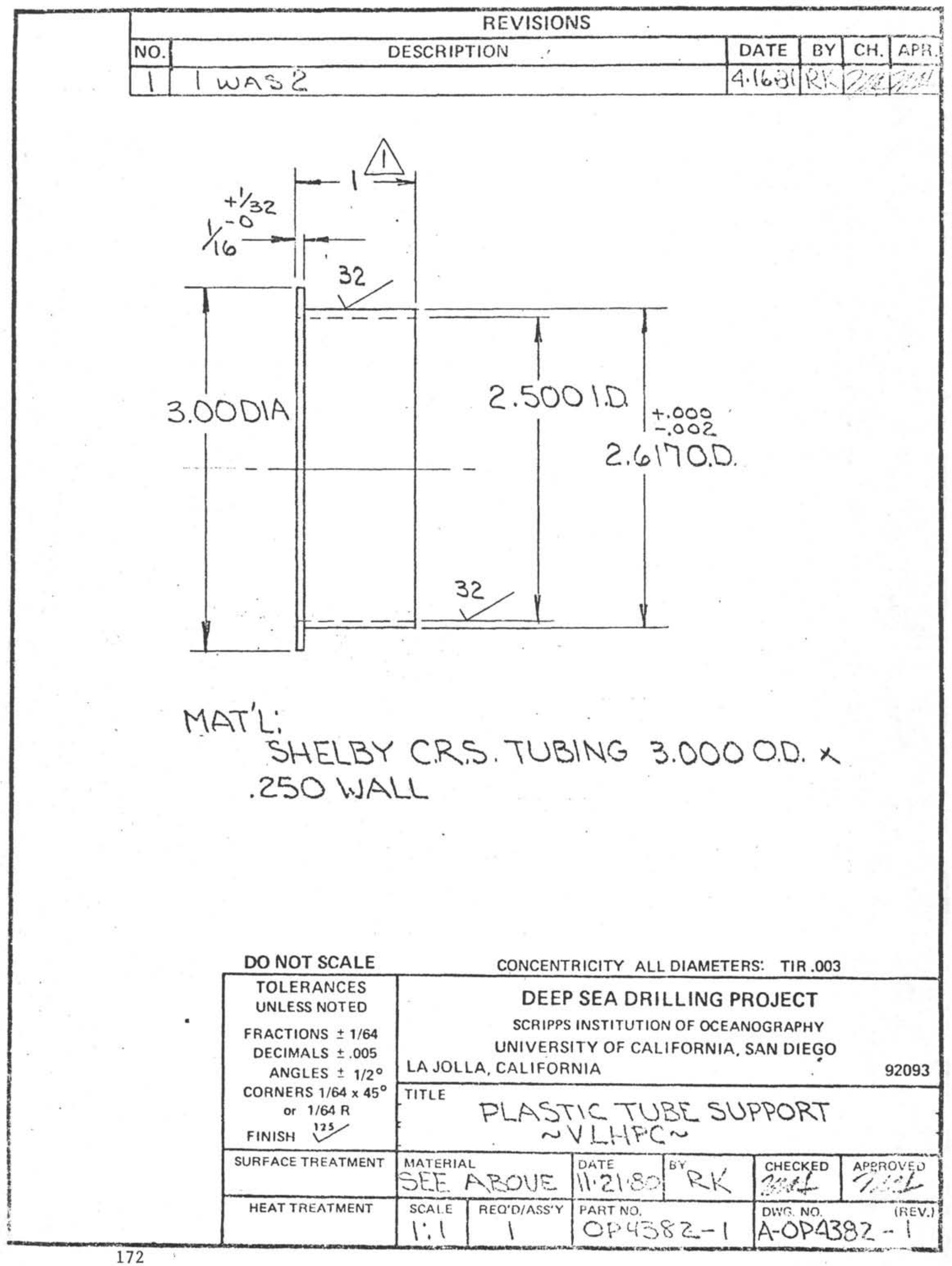




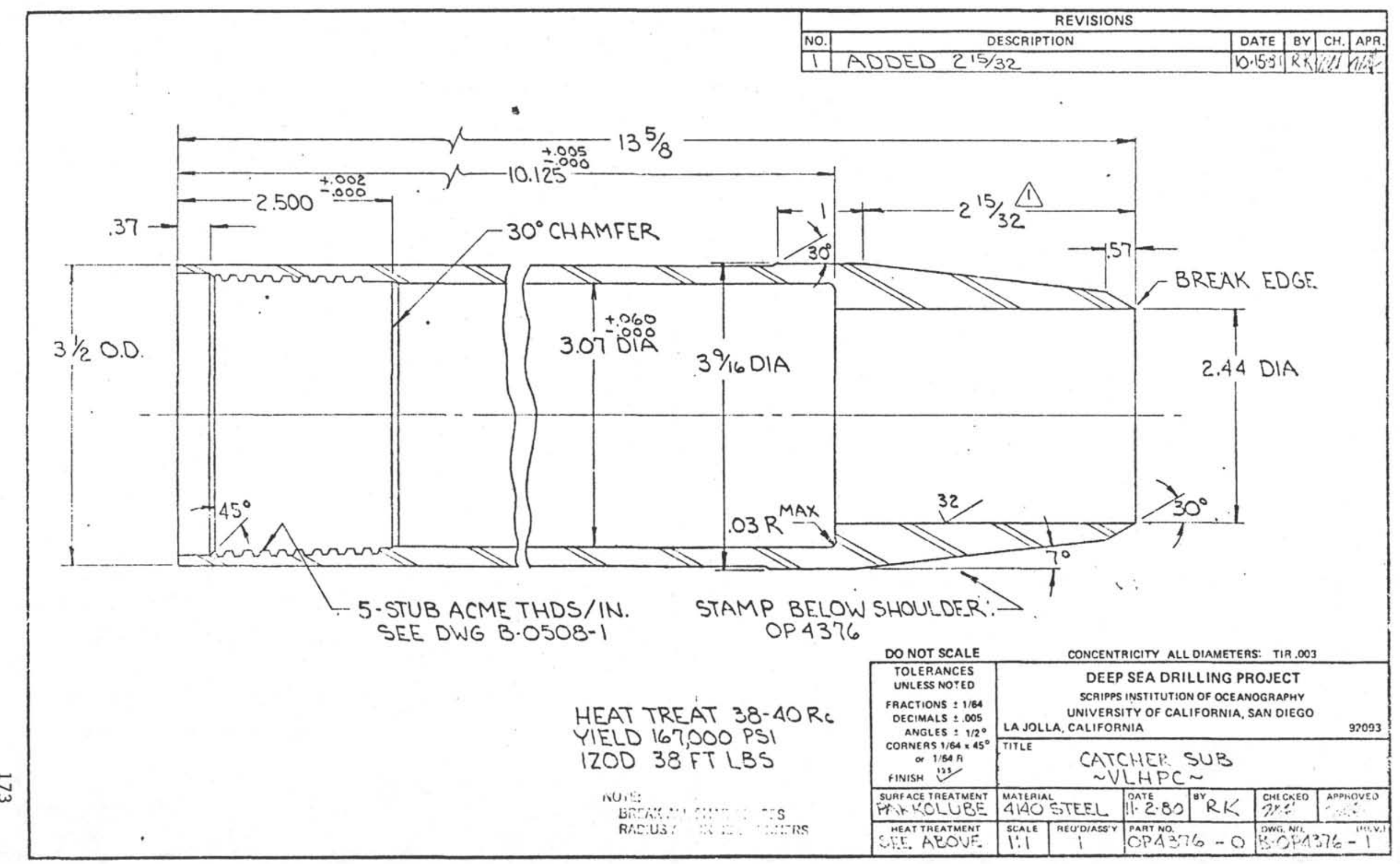




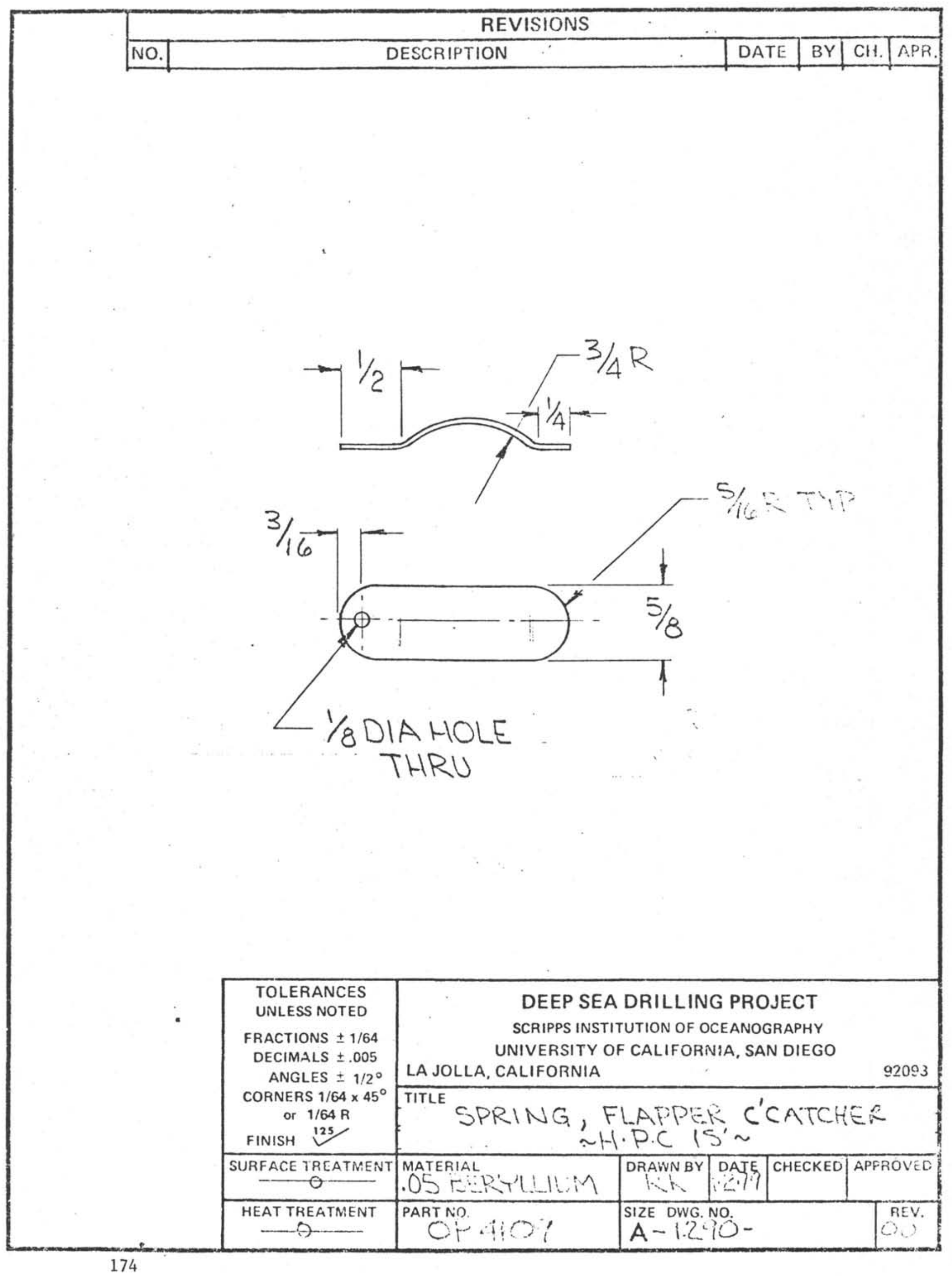




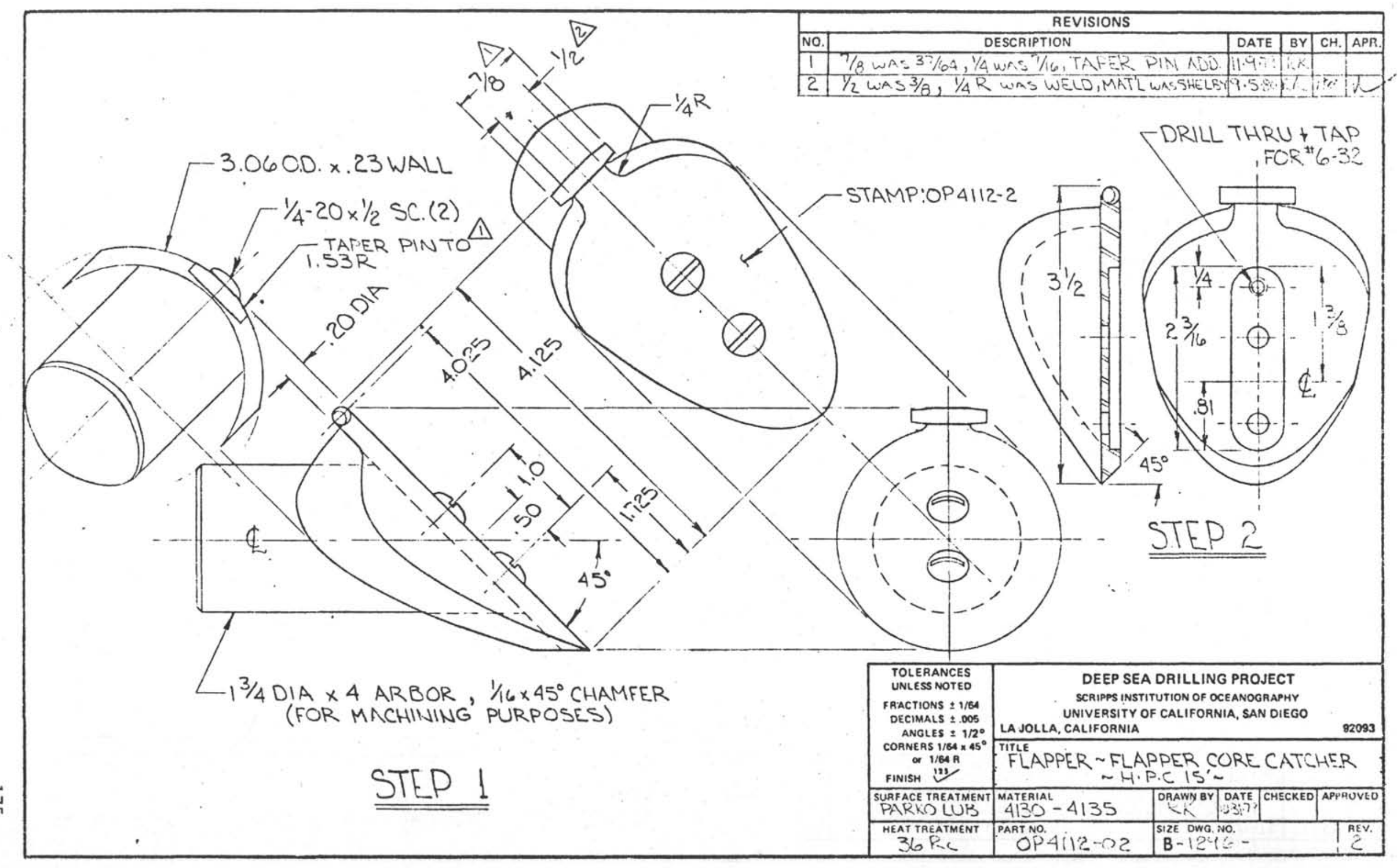




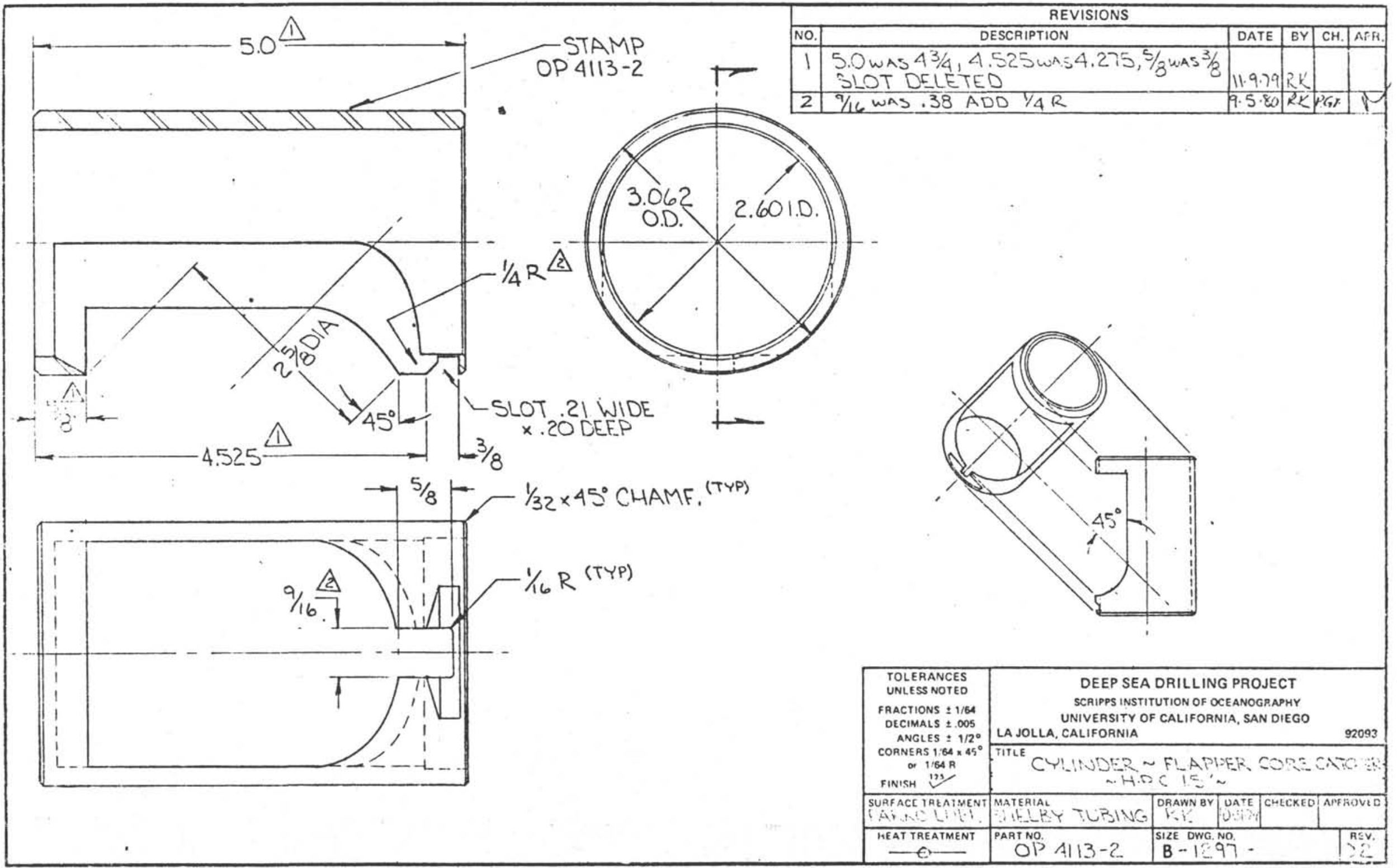




\begin{tabular}{|c|c|c|c|c|c|c|}
\hline \multicolumn{3}{|c|}{ REVISIONS } & \multicolumn{3}{c|}{} \\
\hline NO. & DESCRIPTION & DATE & BY & CH. & APR \\
\hline 3 & REDRAWN & $\cdots$ & 2.3 .81 & RY & YC & UER \\
\hline
\end{tabular}

\section{SMALLDOG FLAP} OR7021

- LARGE DOG FLAP OR7O22.....

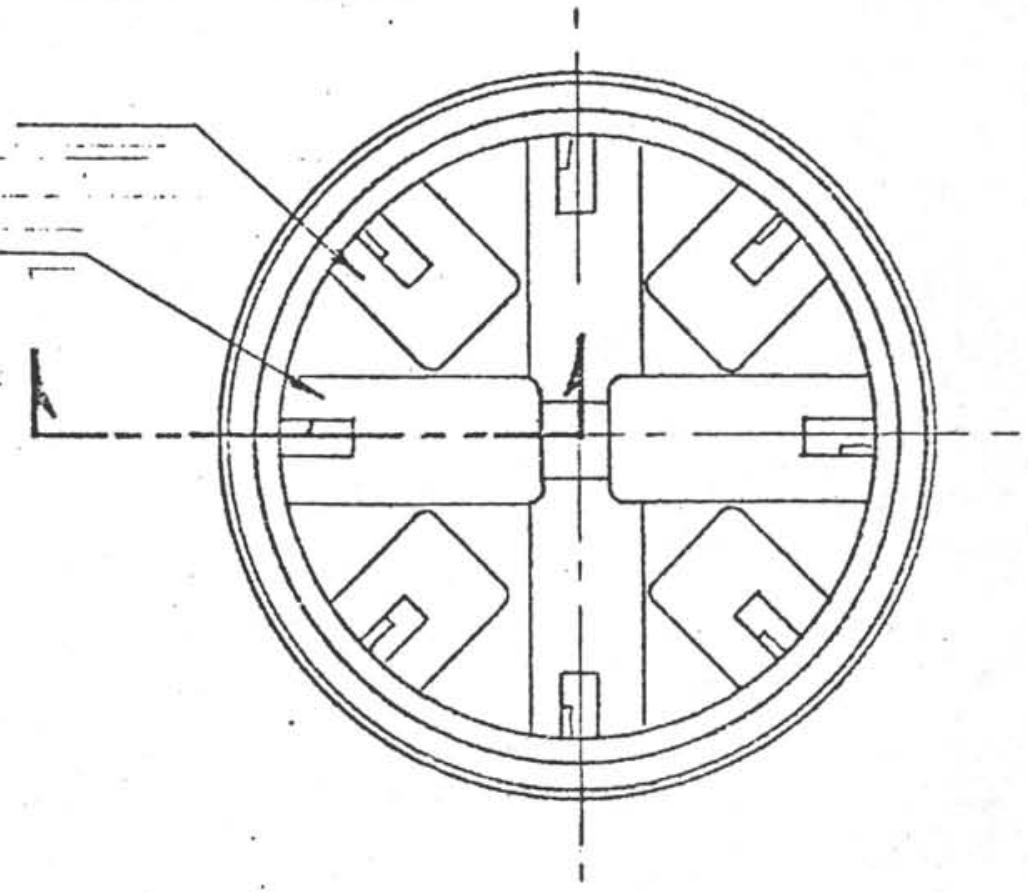

FLANGED RING OR 7014

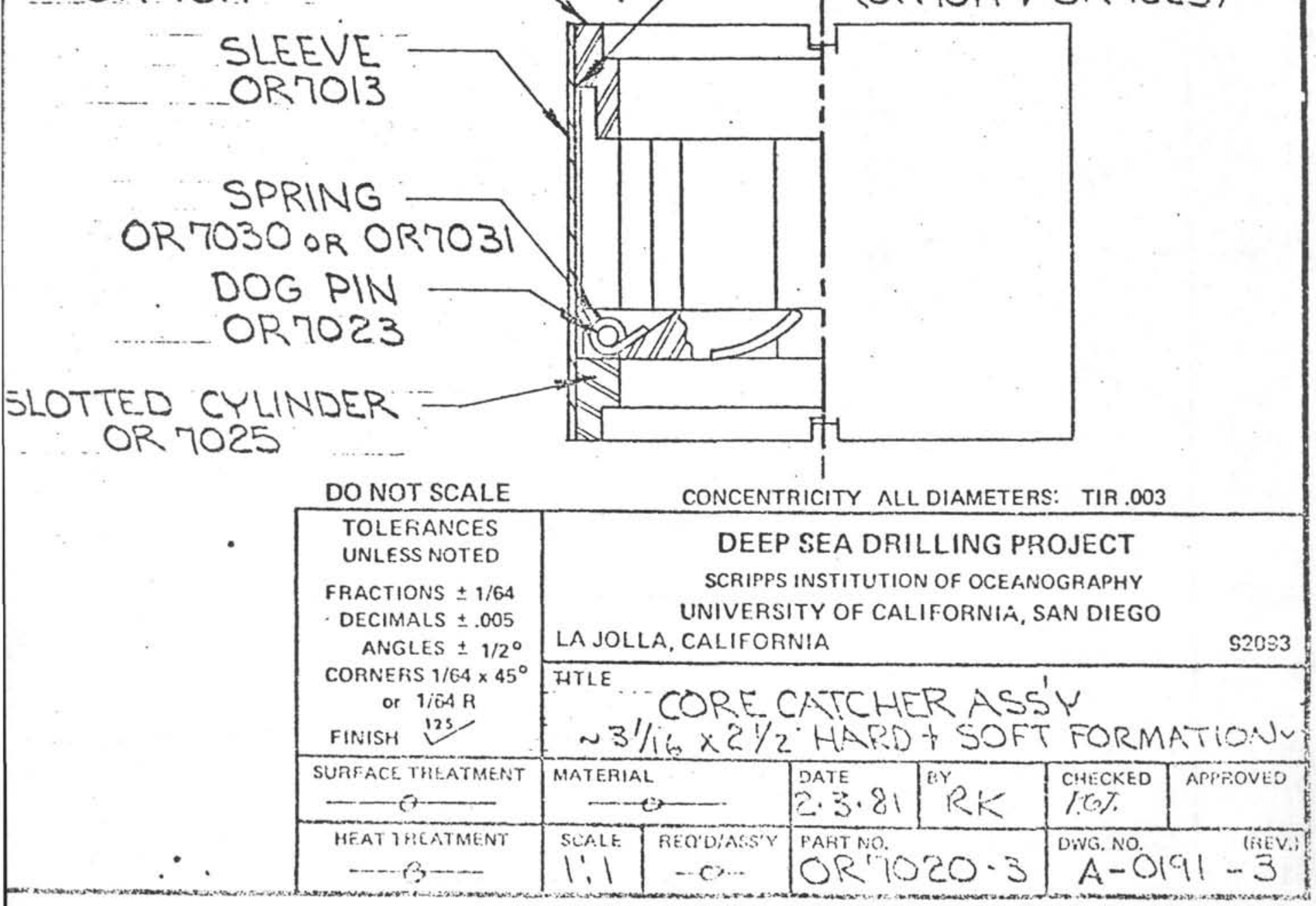




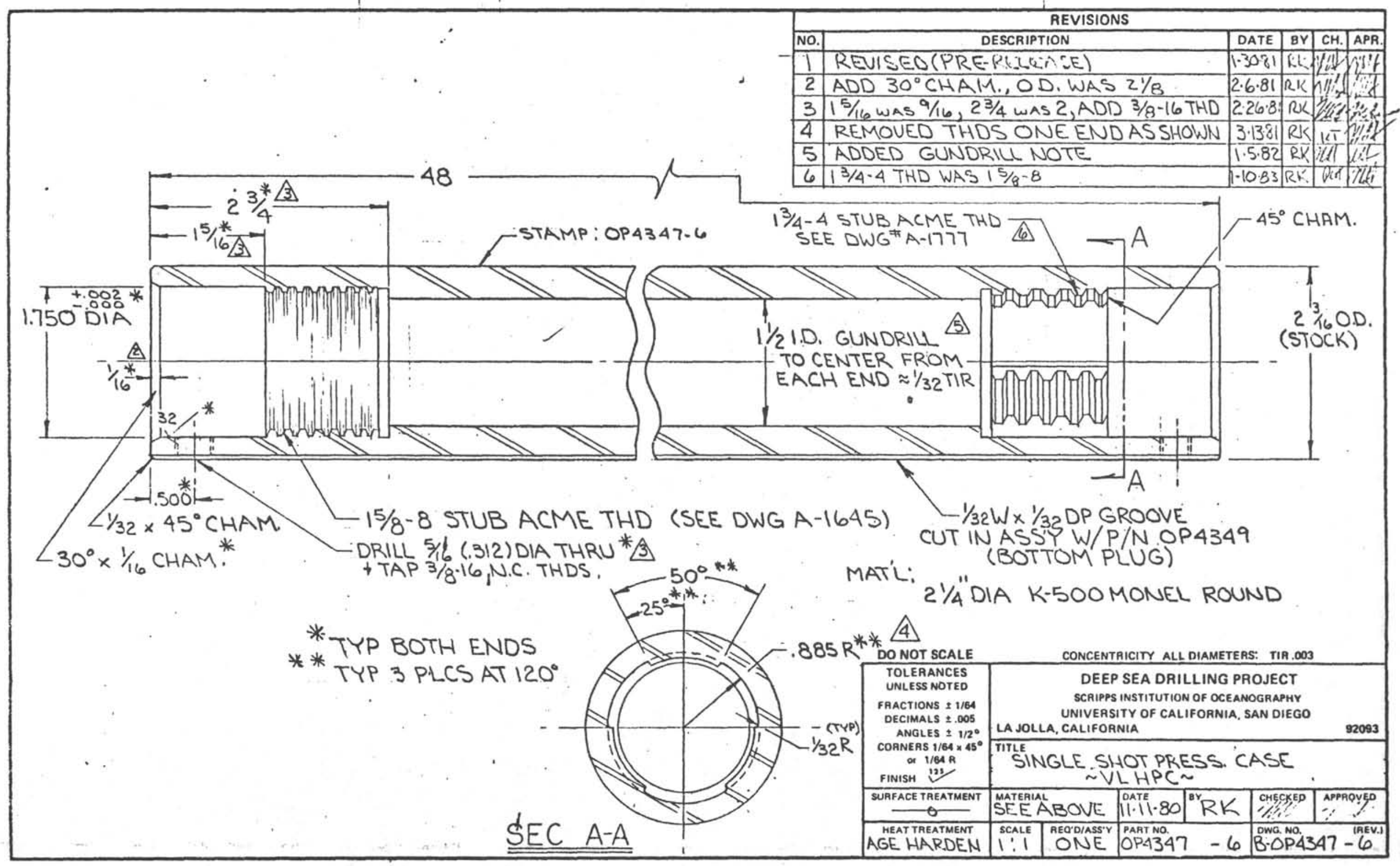



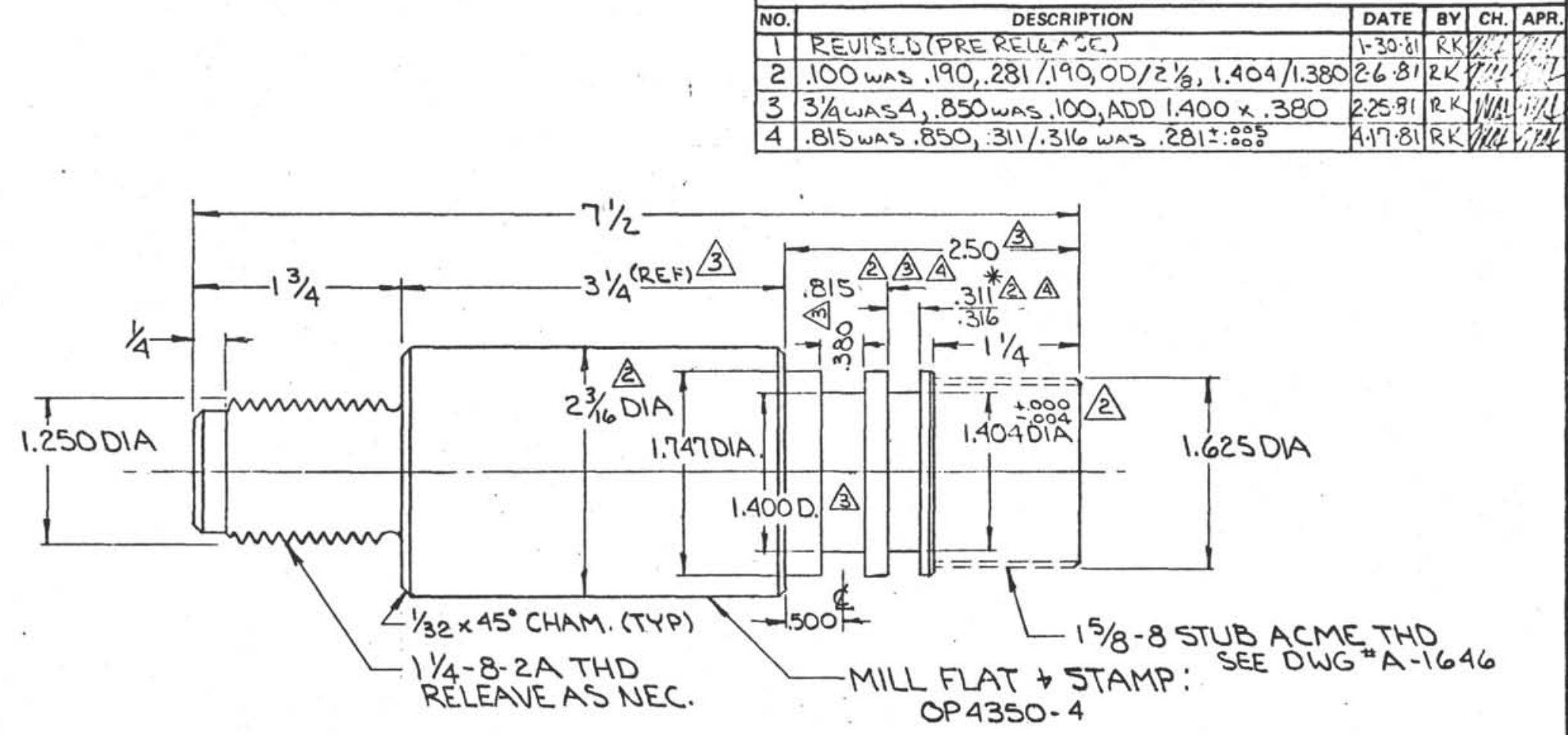

* For o-RING \#2-324

AND PARBAK 8.324

\begin{tabular}{|c|c|c|}
\hline & & \\
\hline $\begin{array}{l}\text { TOLERANCES } \\
\text { UNLES NOTED } \\
\text { FAACTIONS } \pm 1 / 64 \\
\text { OEEIMALS } 1.005 \\
\text { ANGLES }: 1 / 2^{\circ}\end{array}$ & $\begin{array}{r}\text { DEEP SEA } \\
\text { SCRIPPS INSTII } \\
\text { UNIIERSITY OI } \\
\text { LA JOLLA, CALIFORNIA }\end{array}$ & 92093 \\
\hline 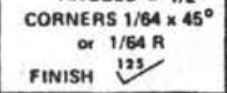 & TITLE SINGLE SS & \\
\hline SUAFACE TREATMENT & 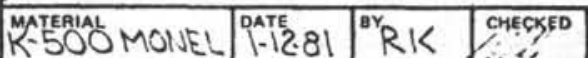 & \\
\hline$\theta$ & \begin{tabular}{l|l}
$1^{2 D / A S S^{\prime} Y}$ & PAAT NO. \\
OP 4350
\end{tabular} & \\
\hline
\end{tabular}




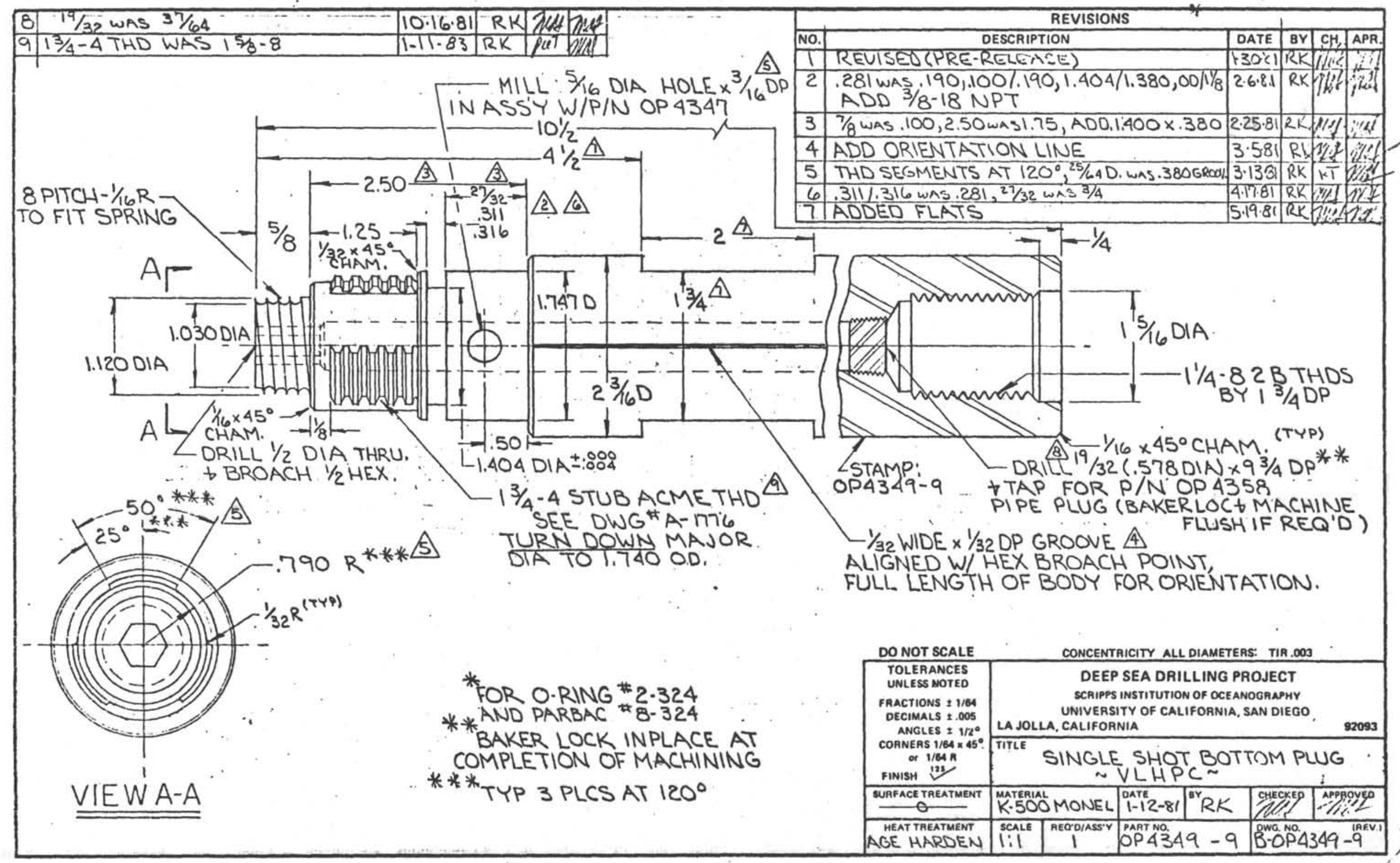



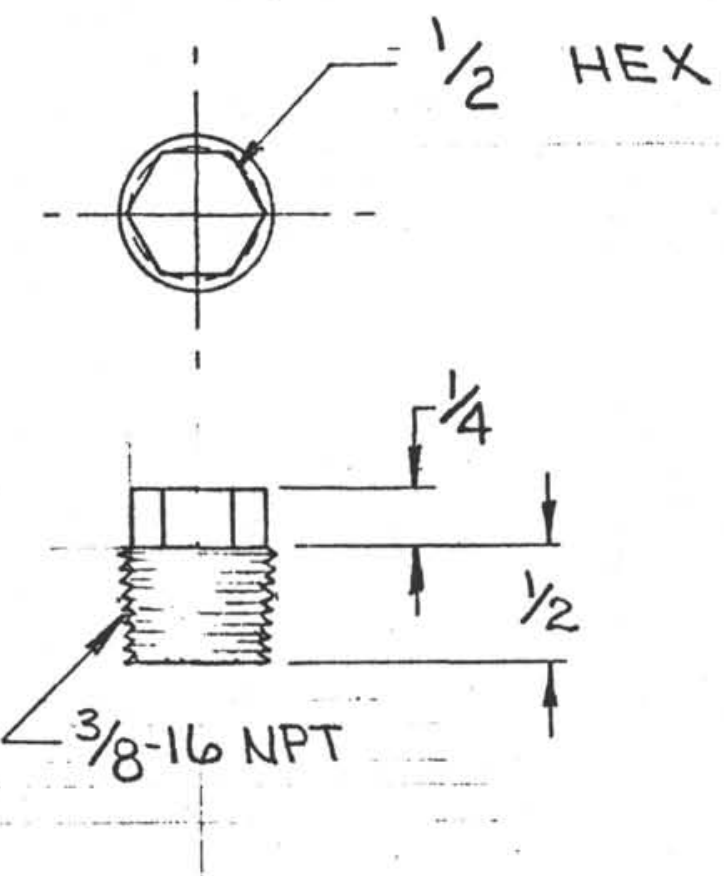

NOTE:

AFTER INSTALLATION TOP OF PLUG MAY REQUIRE MACHINING TO AVOID INTERFERENCE WITH P/N NO.OPA350. BAKER LOC IN PLACE.

DO NOT SCALE

TOLERANCES
UNLESS NOTED

FRACTIONS $\pm 1 / 64$ DECIMALS \pm .005 ANGLES $\pm 1 / 2^{\circ}$ CORNERS $1 / 64 \times 45^{\circ}$ or $1 / 64 R$ FINISH 125 CONCENTRICITY ALL DIAMETERS: TIR .003

\section{DEEP SEA DRILLING PROJECT}

SCRIPPS INSTITUTION OF OCEANOGRAPHY UNIVERSITY OF CALIFORNIA, SAN DIEGO

LA JOLLA, CALIFORNIA

TITLE

PIPE PLUG-SINGLE SHOT BOTTOM PLUG $\sim V L \cdot H P C \sim$

SURFACE TREATMENT

OW

MATERIAL

HEAT TREATMENT NITRONIC 60 DATE SCALE SCALE REGO/ASS'Y PAFT NO. OP4 458

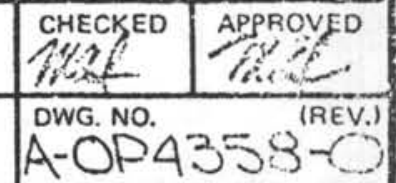




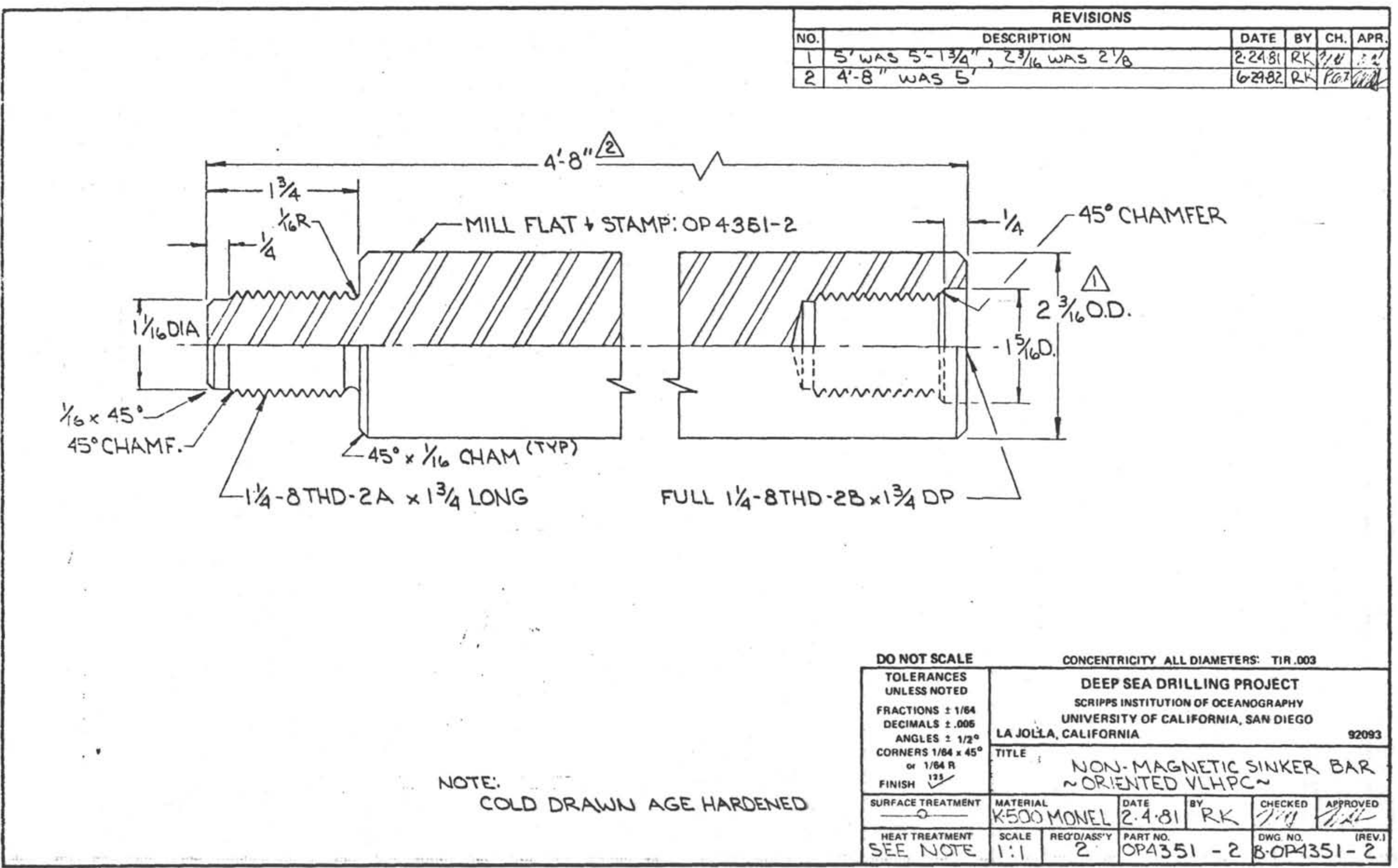




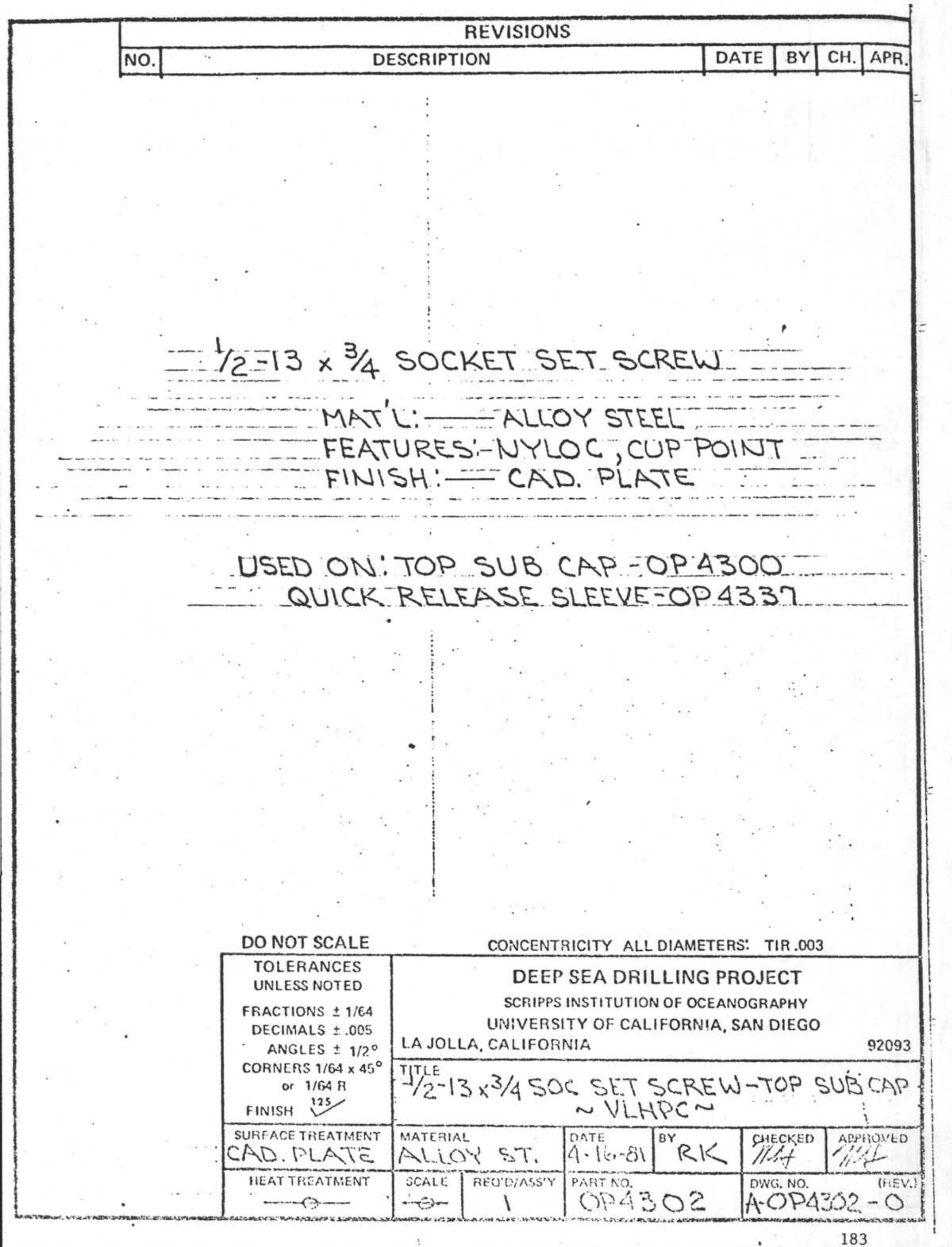




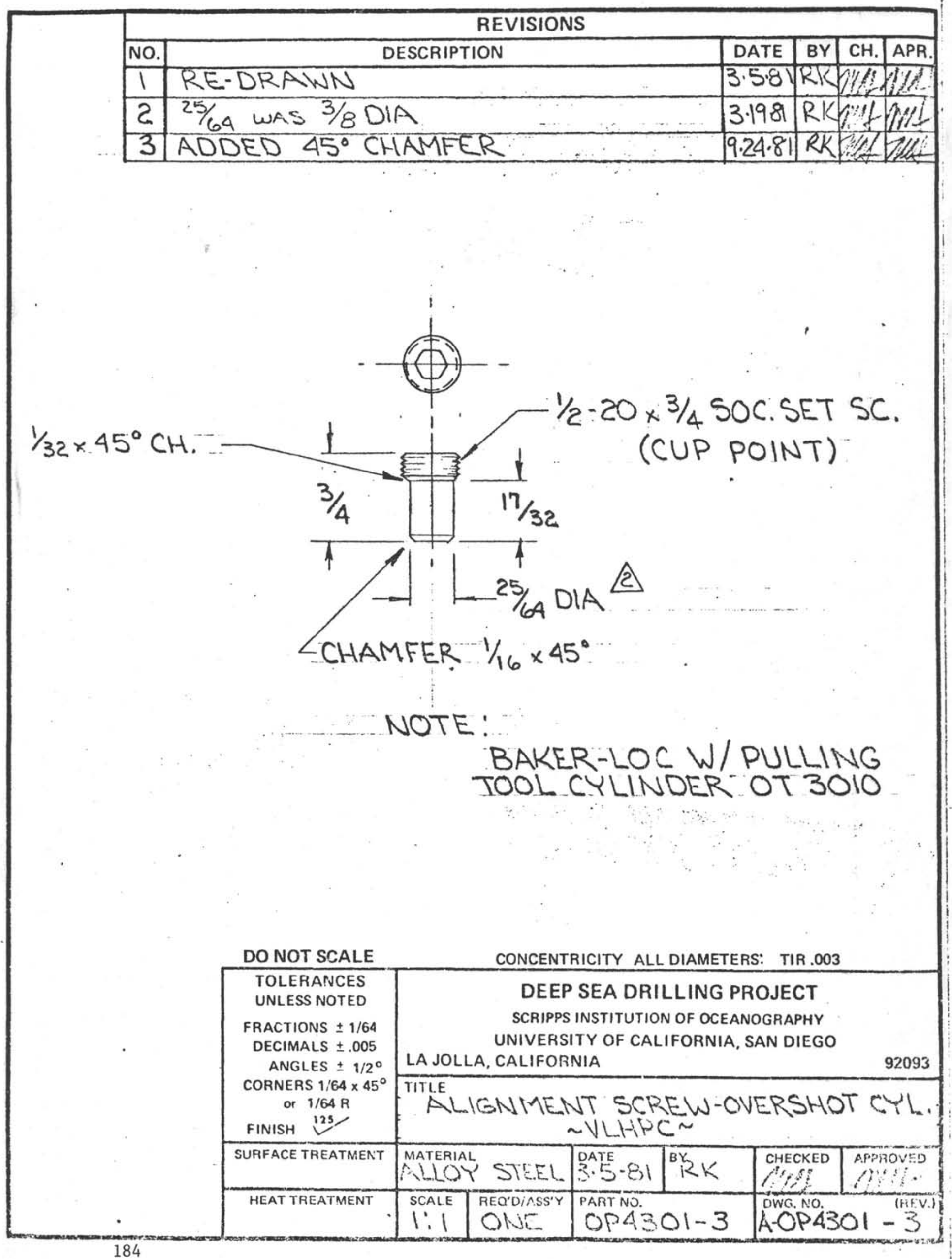




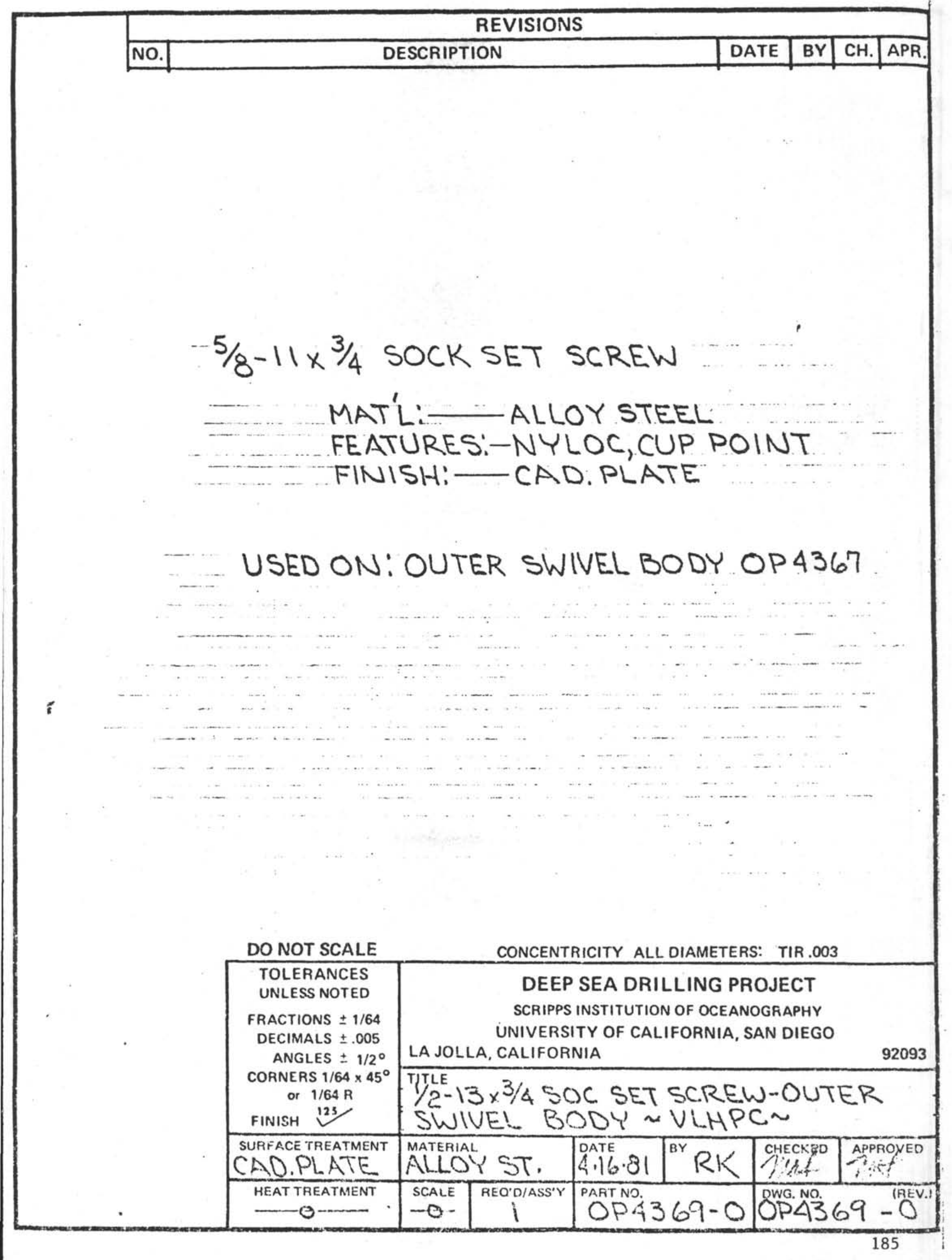




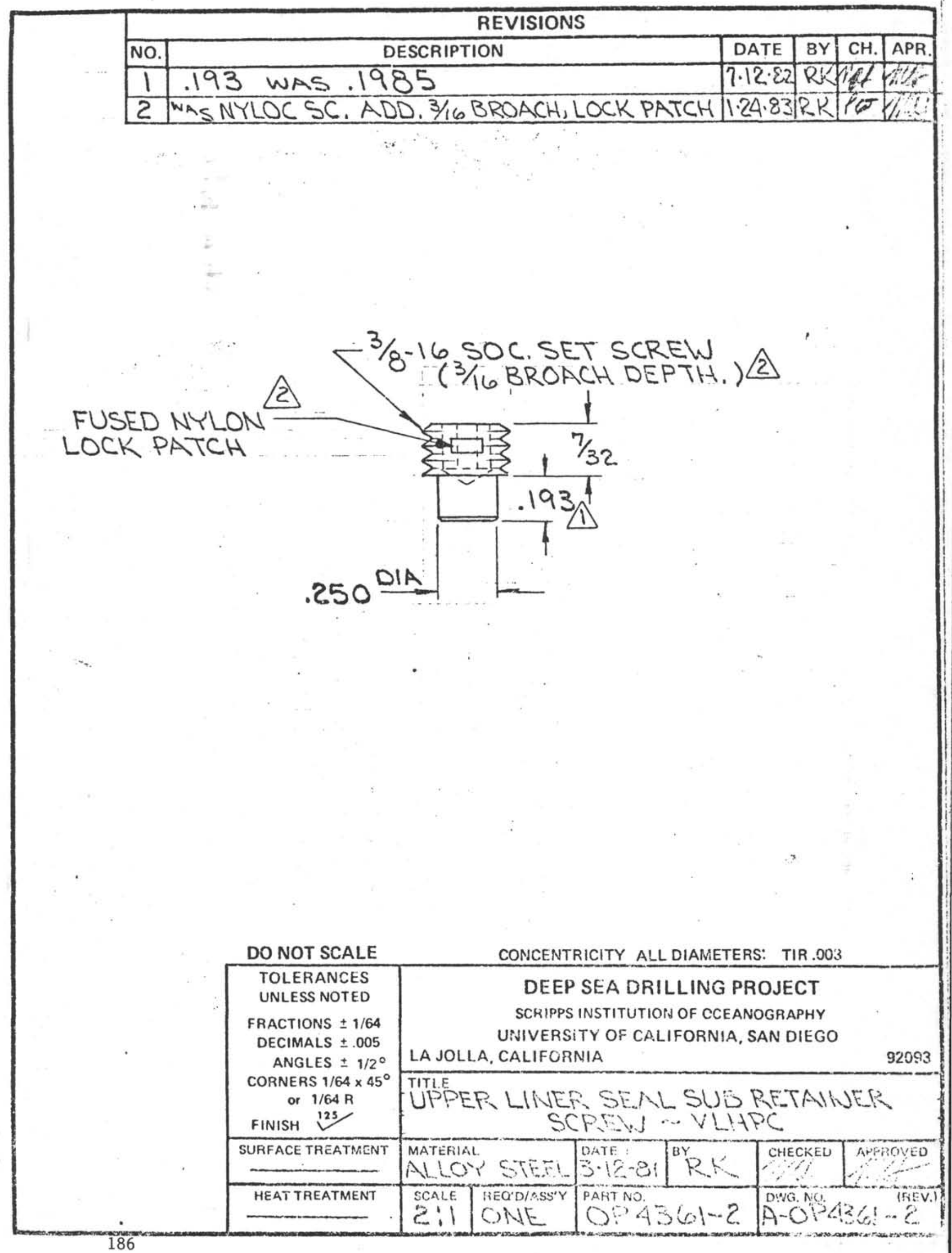




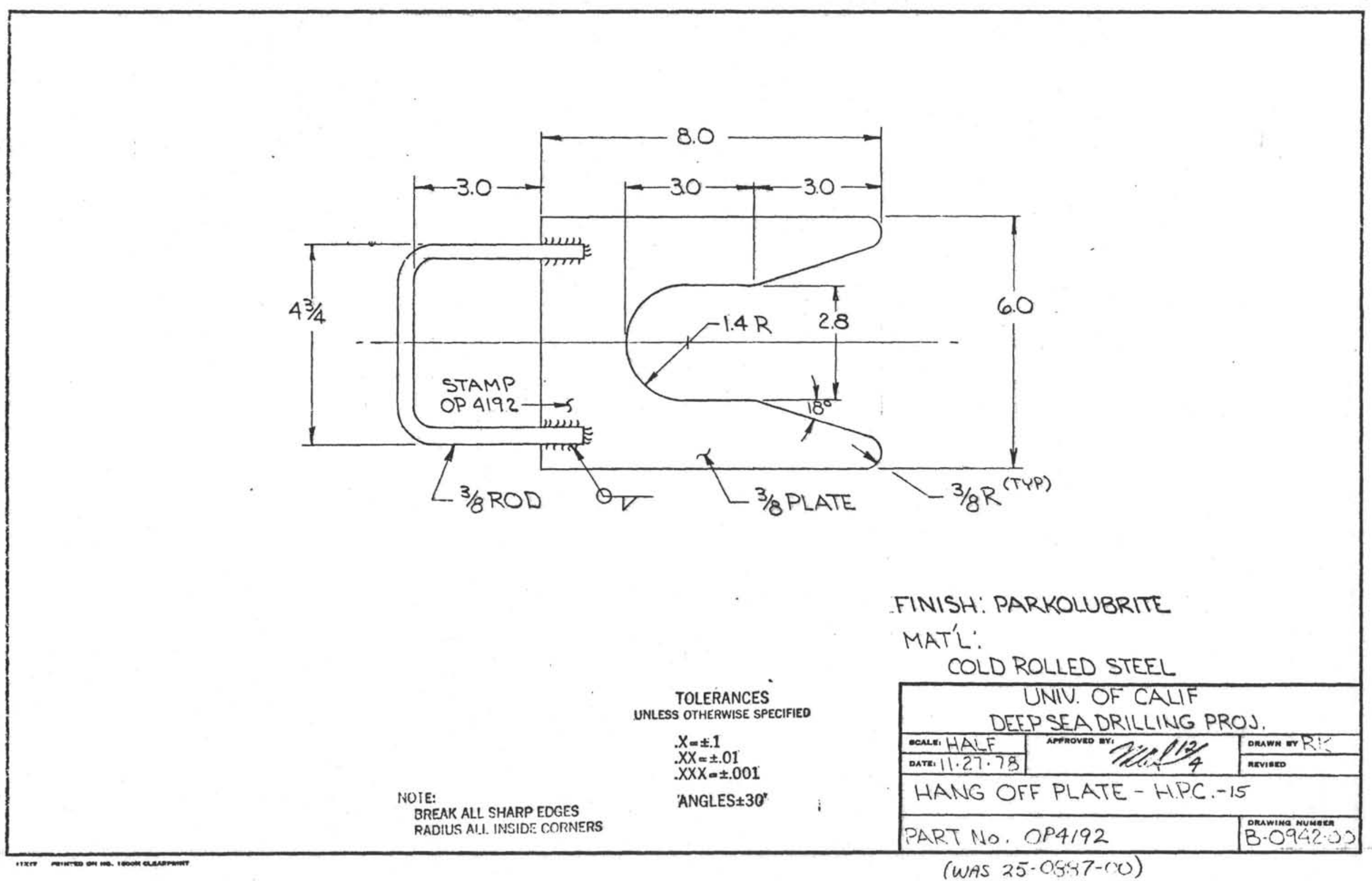



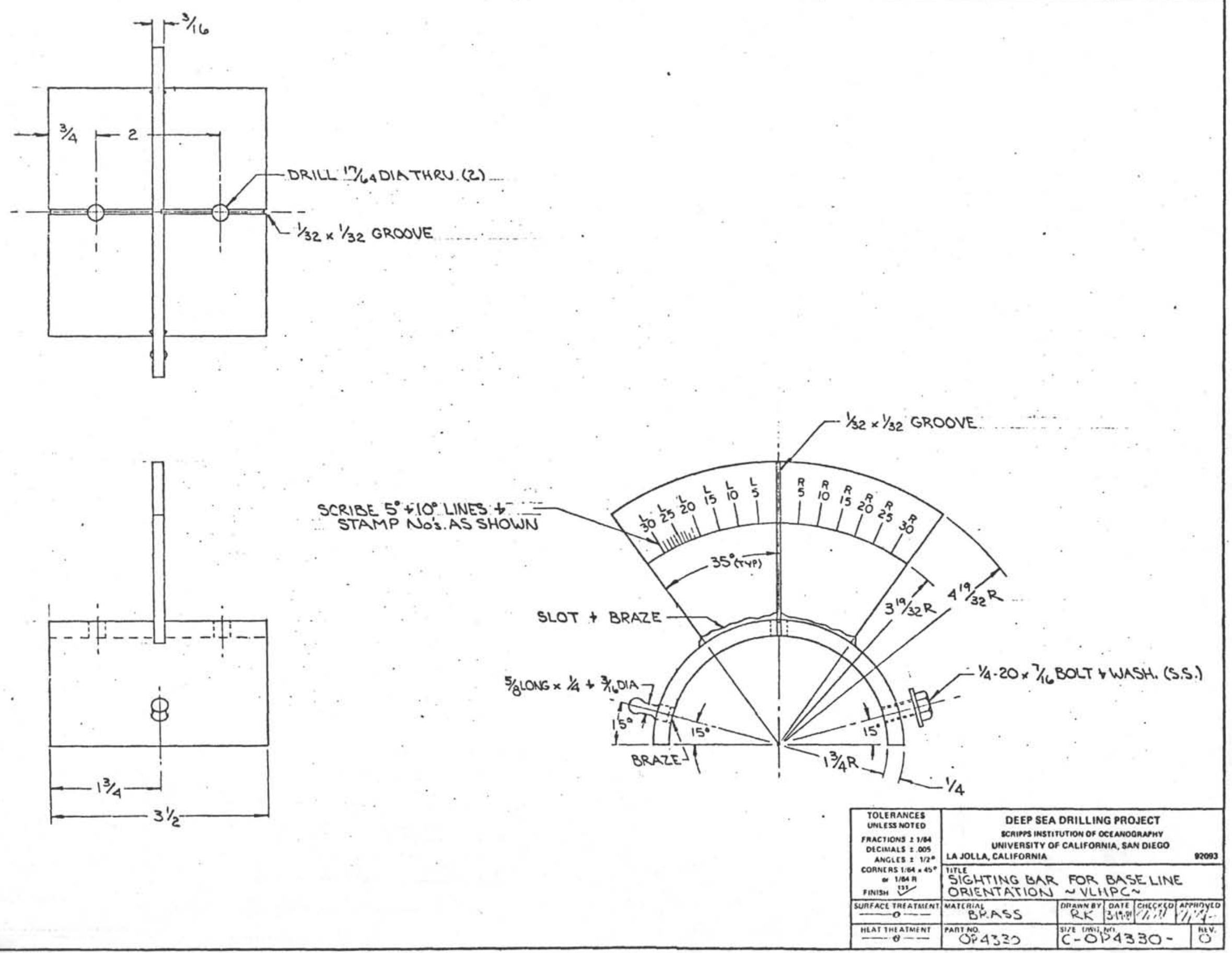


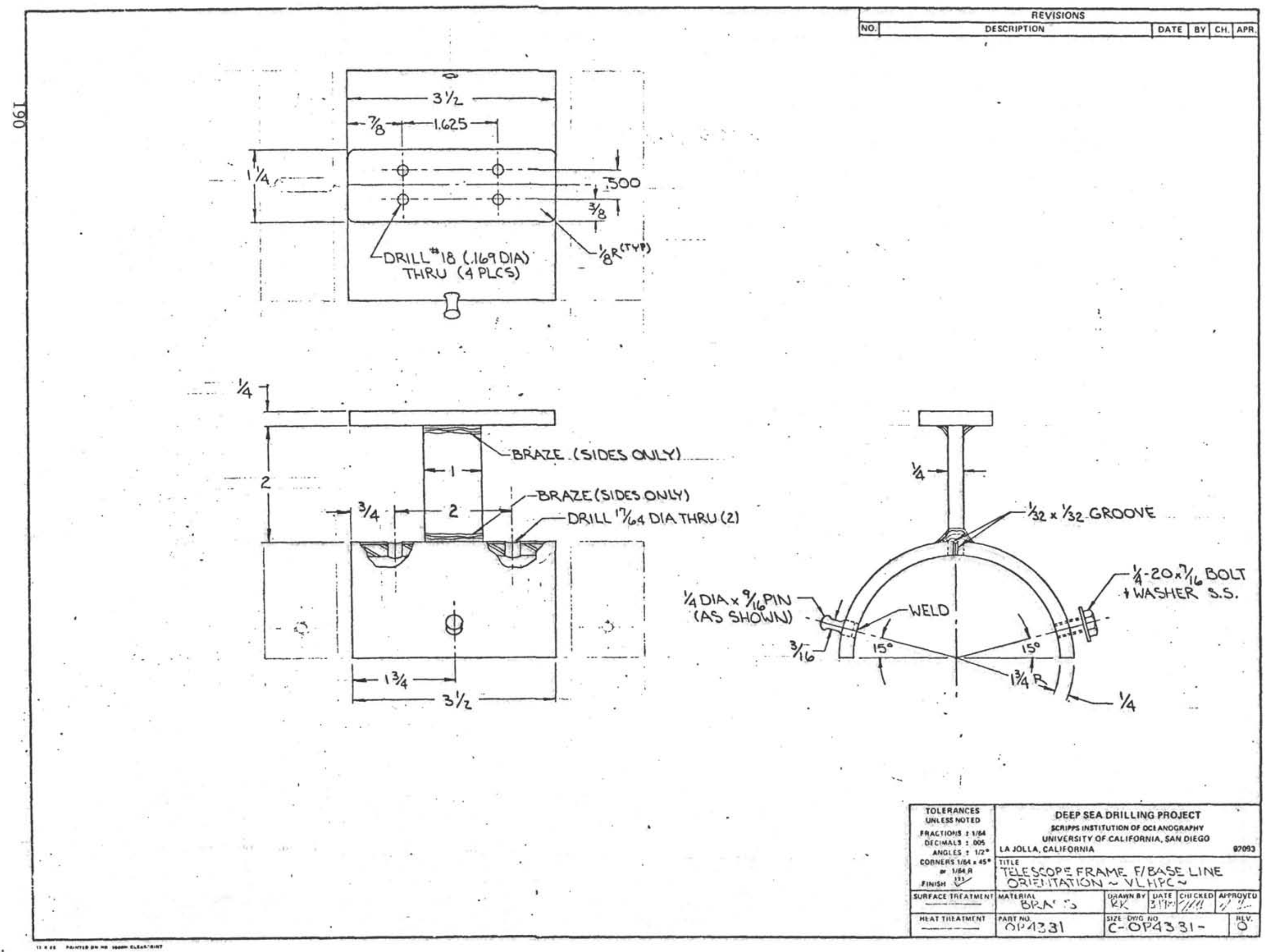




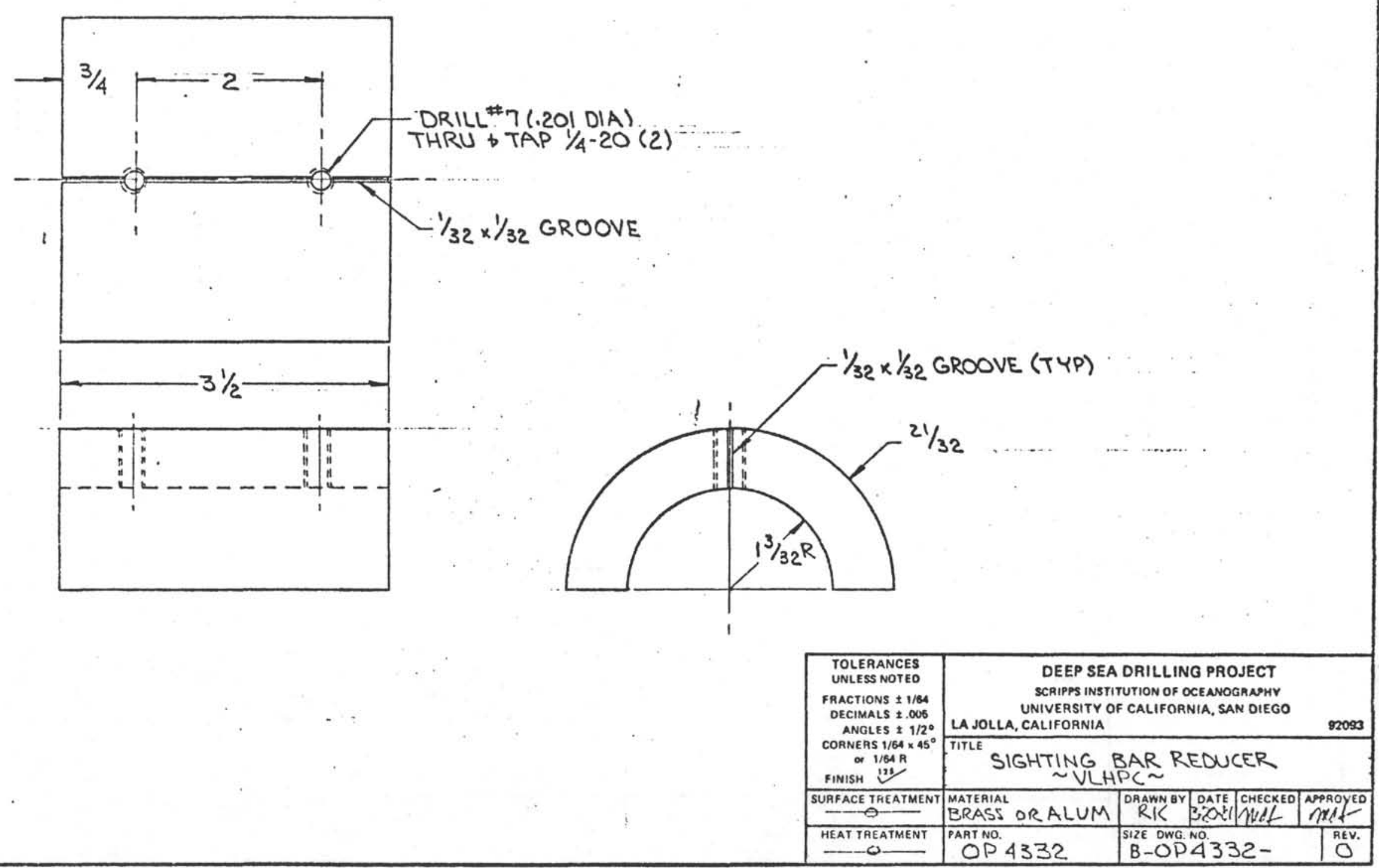




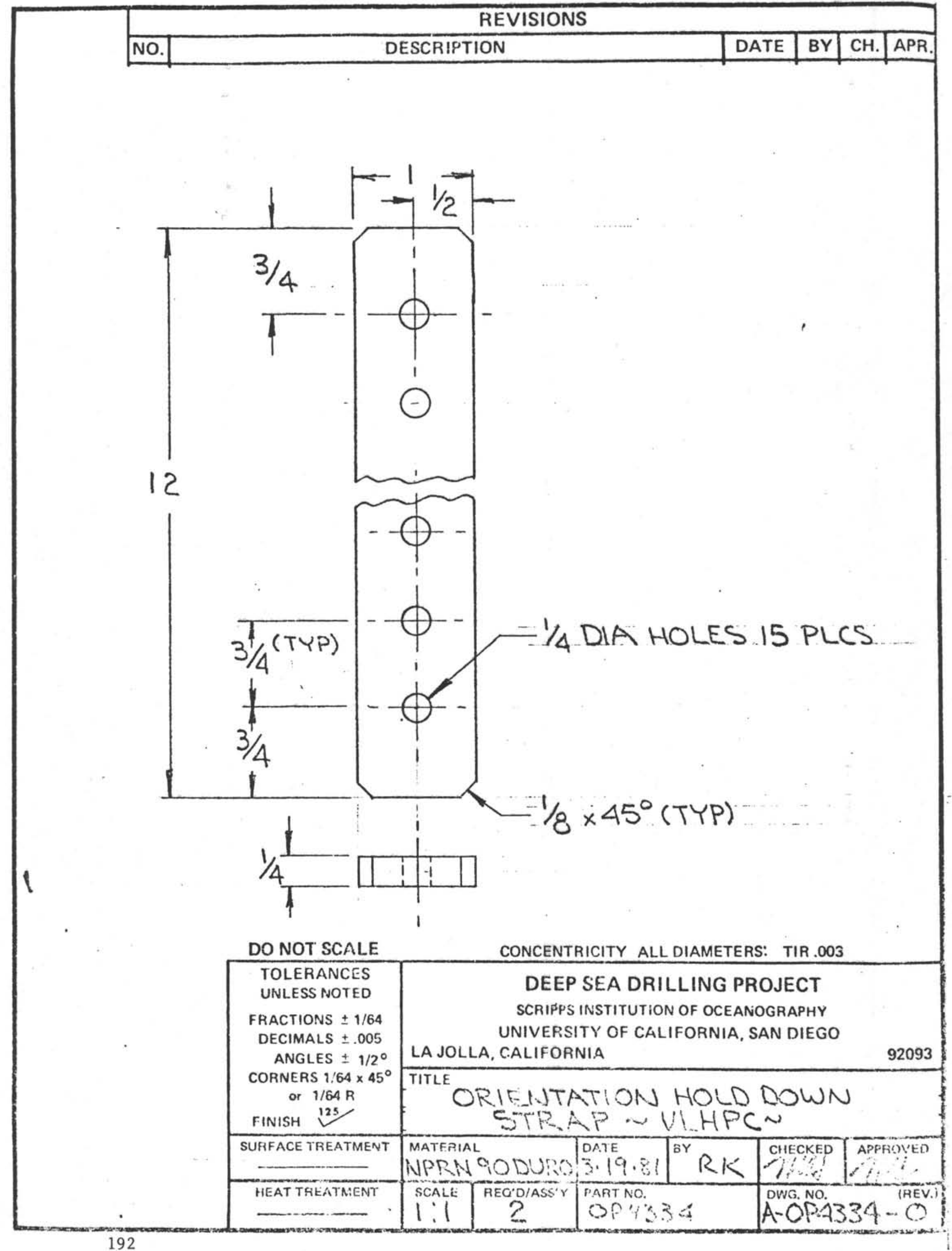




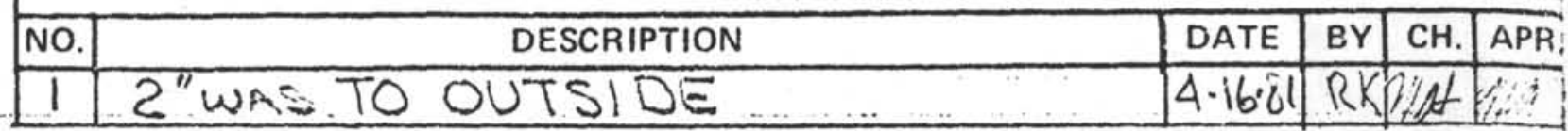

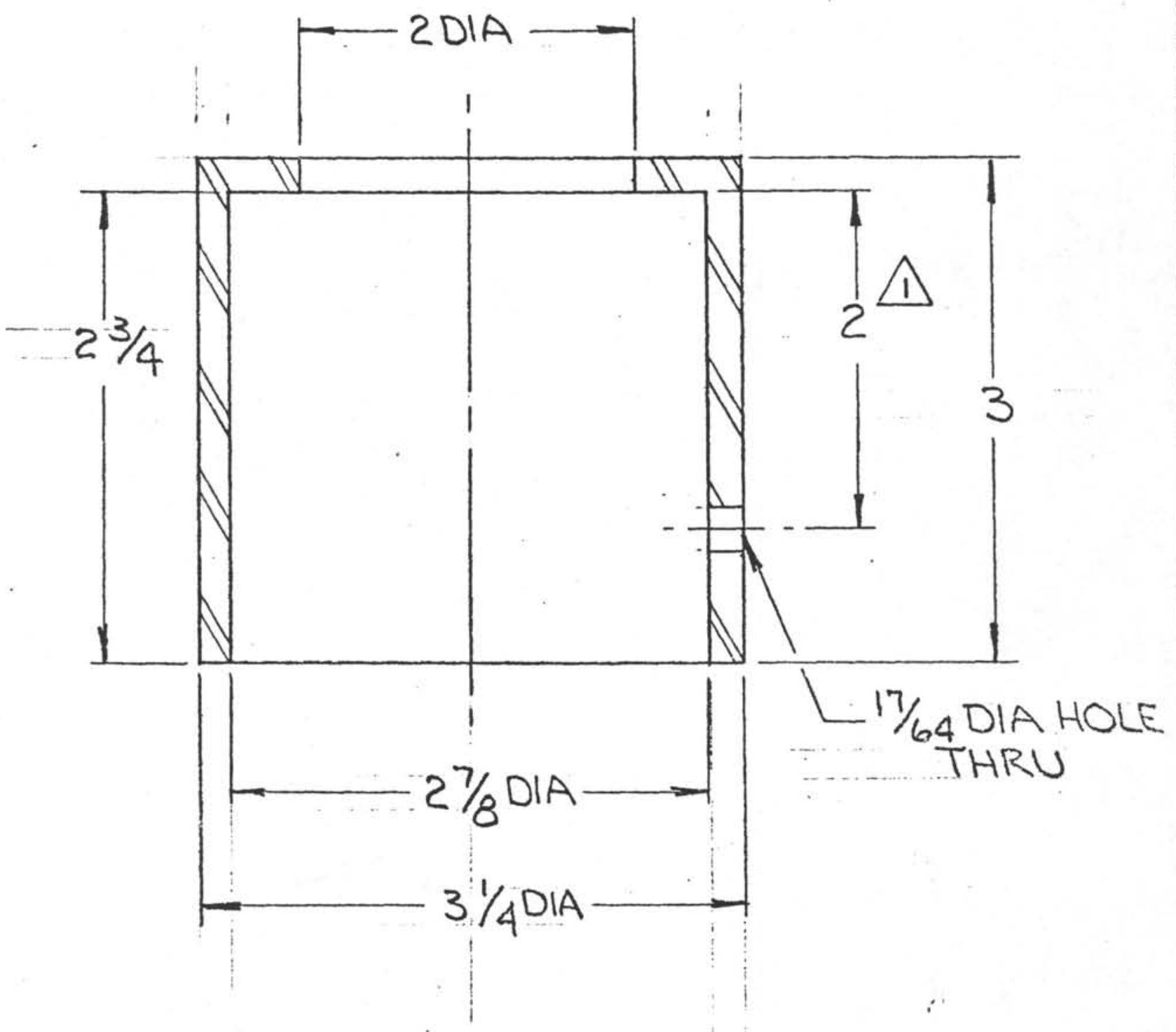

DO NOT SCALE TOLERANCES UNLESS NOTED

FRACTIONS $\pm 1 / 64$ DECIMALS \pm .005 ANGLES $\pm 1 / 2^{\circ}$ CORNERS $1 / 64 \times 45^{\circ}$ or $1 / 64 R$
FINISH $125 /$
CONCENTRICITY ALL DIAMETERS: TIR.003

\section{DEEP SEA DRILLING PROJECT}

SCRIPPS INSTITUTION OF OCEANOGRAPHY

UNIVERSITY OF CALIFORNIA, SAN DIEGO

92093

ORILL JIG-CORE LINER $\approx V L H P C \sim$

\begin{tabular}{|c|c|c|c|}
\hline $\begin{array}{l}\text { DATE } \\
4 \cdot 1 \cdot 81\end{array}$ & ${ }^{B Y} R K$ & $\begin{array}{l}\text { CHECKED } \\
\text { PKS }\end{array}$ & APProyED \\
\hline
\end{tabular}




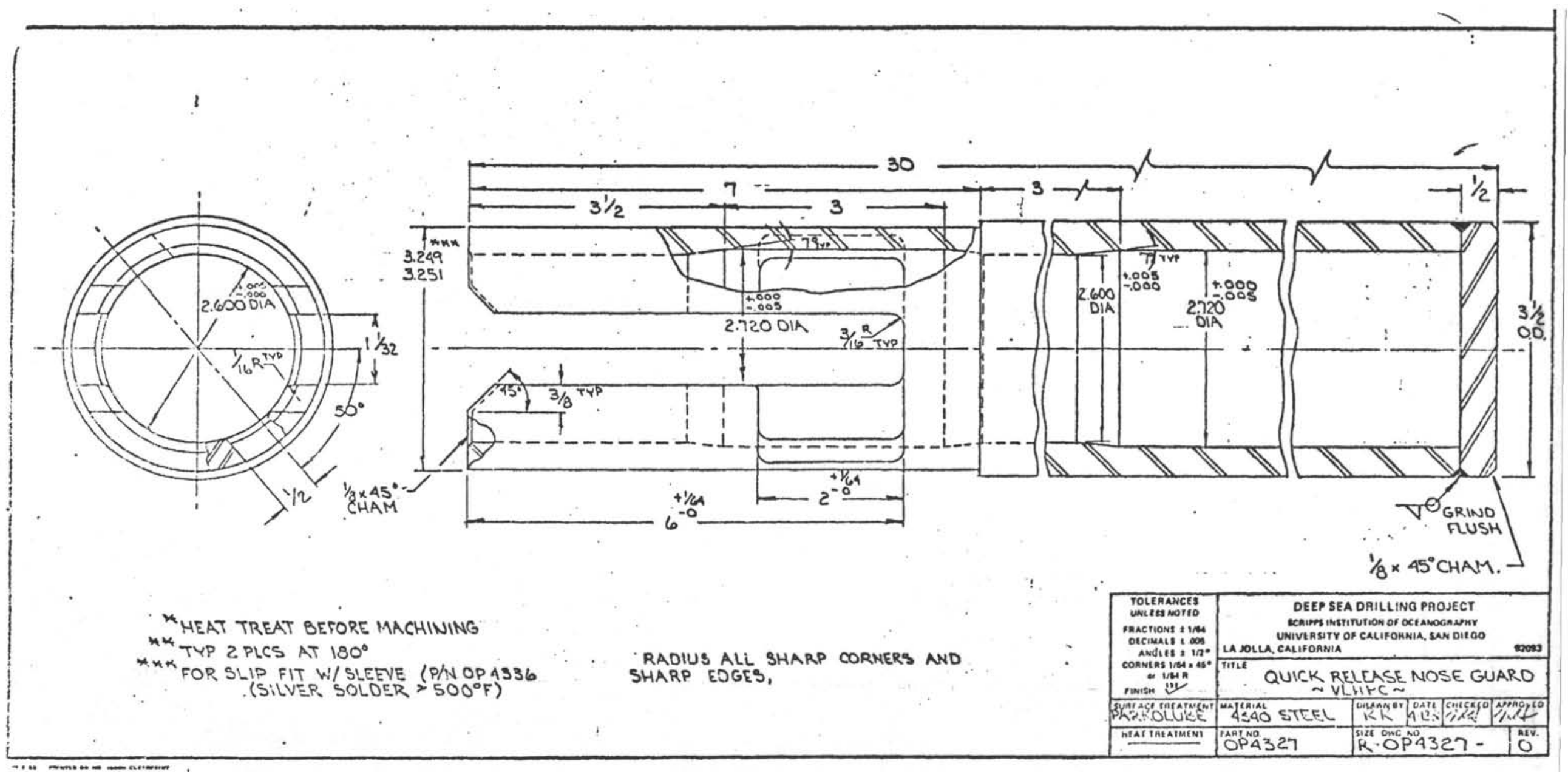




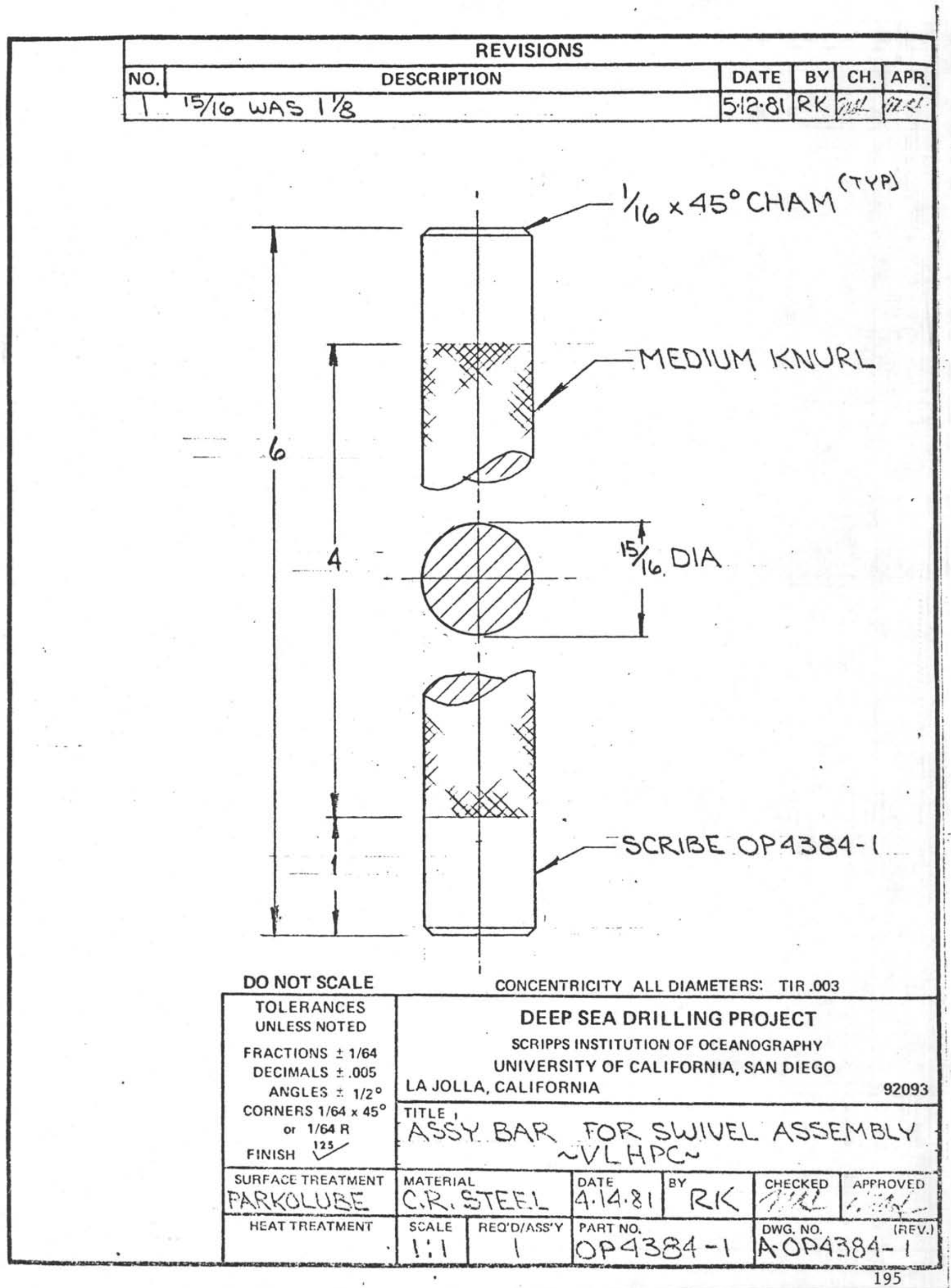




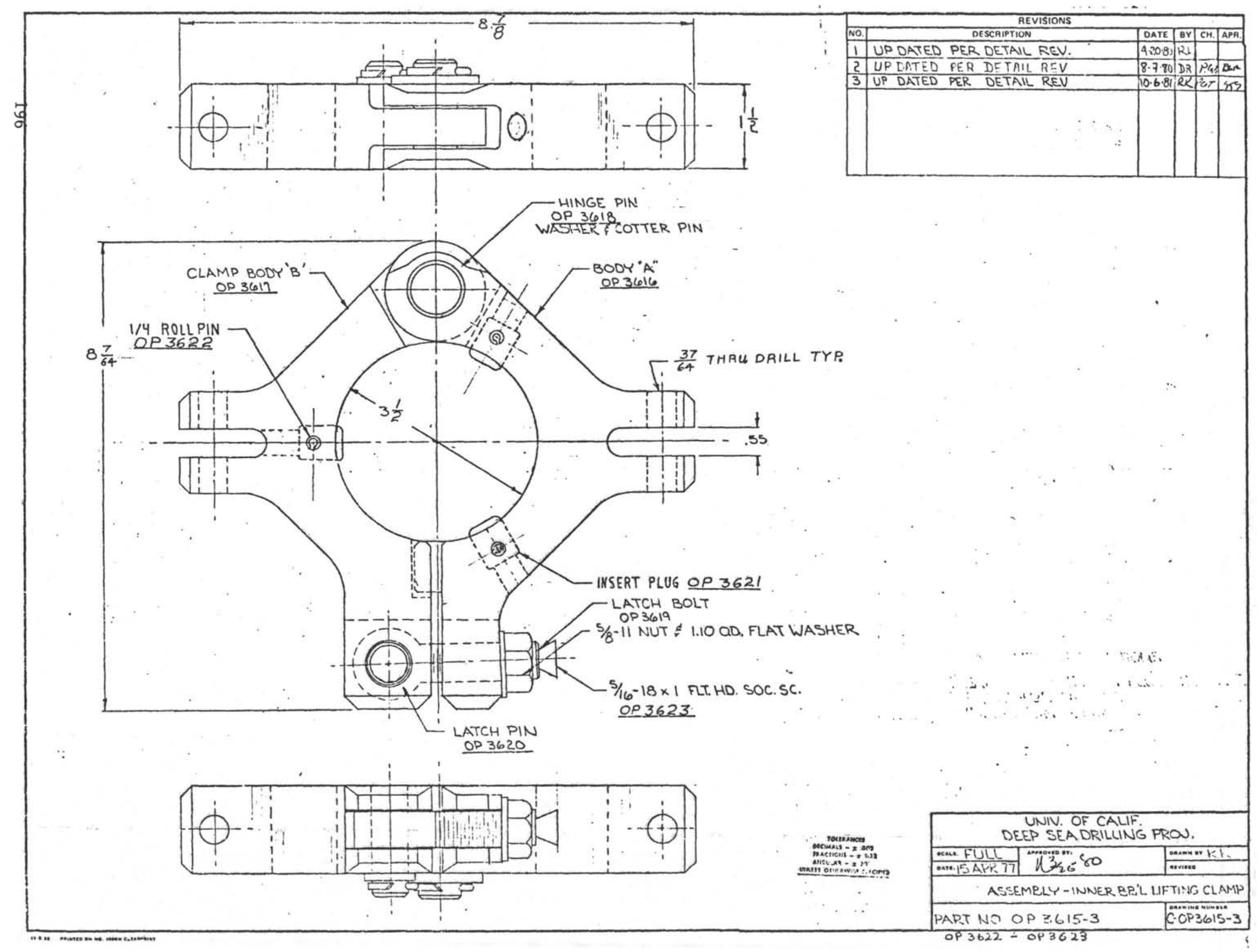




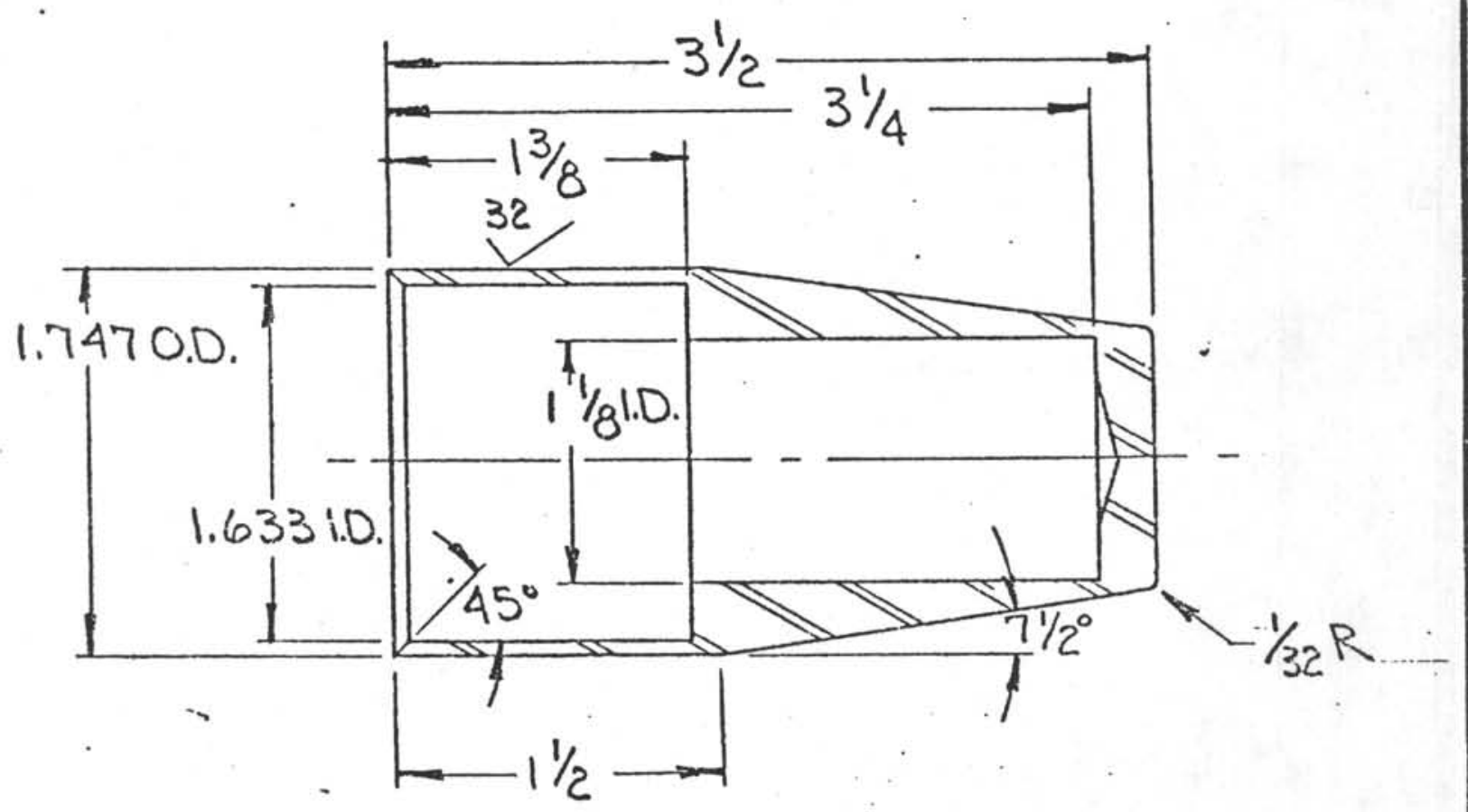

\section{NOTES ?}

BREAK ALI' SHARP EDGES

RACIUS ALL INSIDE CORNERS

DO NOT SCALE TOLERANCES UNLESS NOTED

FRACTIONS $\pm 1 / 64$

DECIMALS \pm .005

ANGLES $\pm 1 / 2^{\circ}$ COPNERS $1 / 64 \times 45^{\circ}$

FINISH$$
\text { or } 1 / 64 \mathrm{R}
$$

CONCENTRICITY ALL DIAMETERS: TIR.003

\section{DEEP SEA DRILLING PROJECT}

SCRIPPS INSTITUTION OF OCEANOGRAPHY UNIVERSITY OF CALIFORNIA, SAN DIECOO LA JOLLA. CALIFORNIA

TITLE

SEAL INSTALLATIOA-TOOL-PRESS CASE $\sim$ VLHPC心

\section{SUIFFACE TFEATM!ENT}

-

HEAT RHEATMENT

.....-C

C............

1

N:ATEFIAL

BRNSS

SCALE

HECU'A'ASS'Y

-O.....

$1: 1$

DATE

$5 \cdot 19 \cdot 8$

PAFit NO

001505
ShECKEA fOPFOYEO n'sic Divo . NO

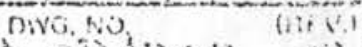
$A-(1) A B(5) \cdots()$ 


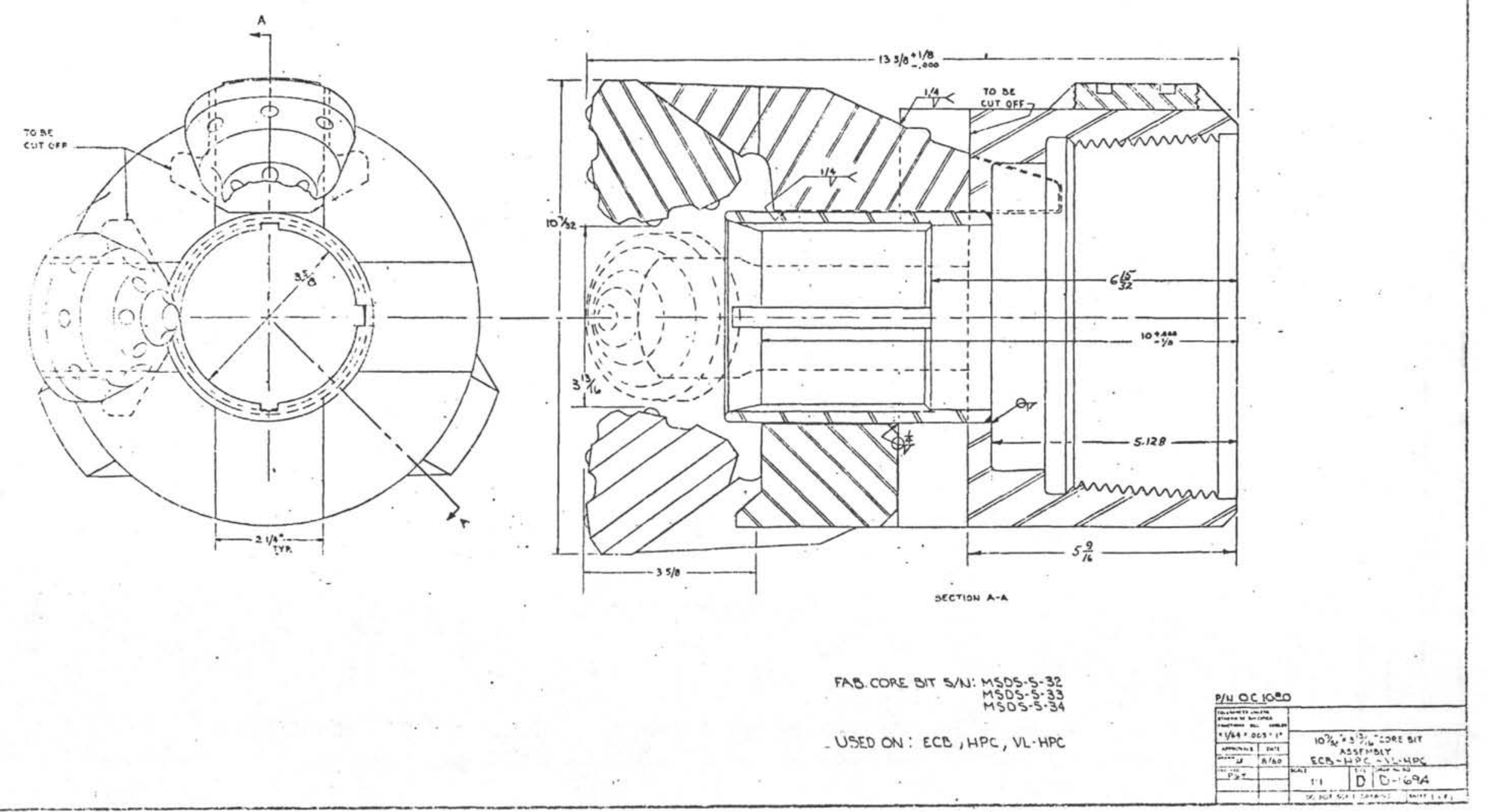




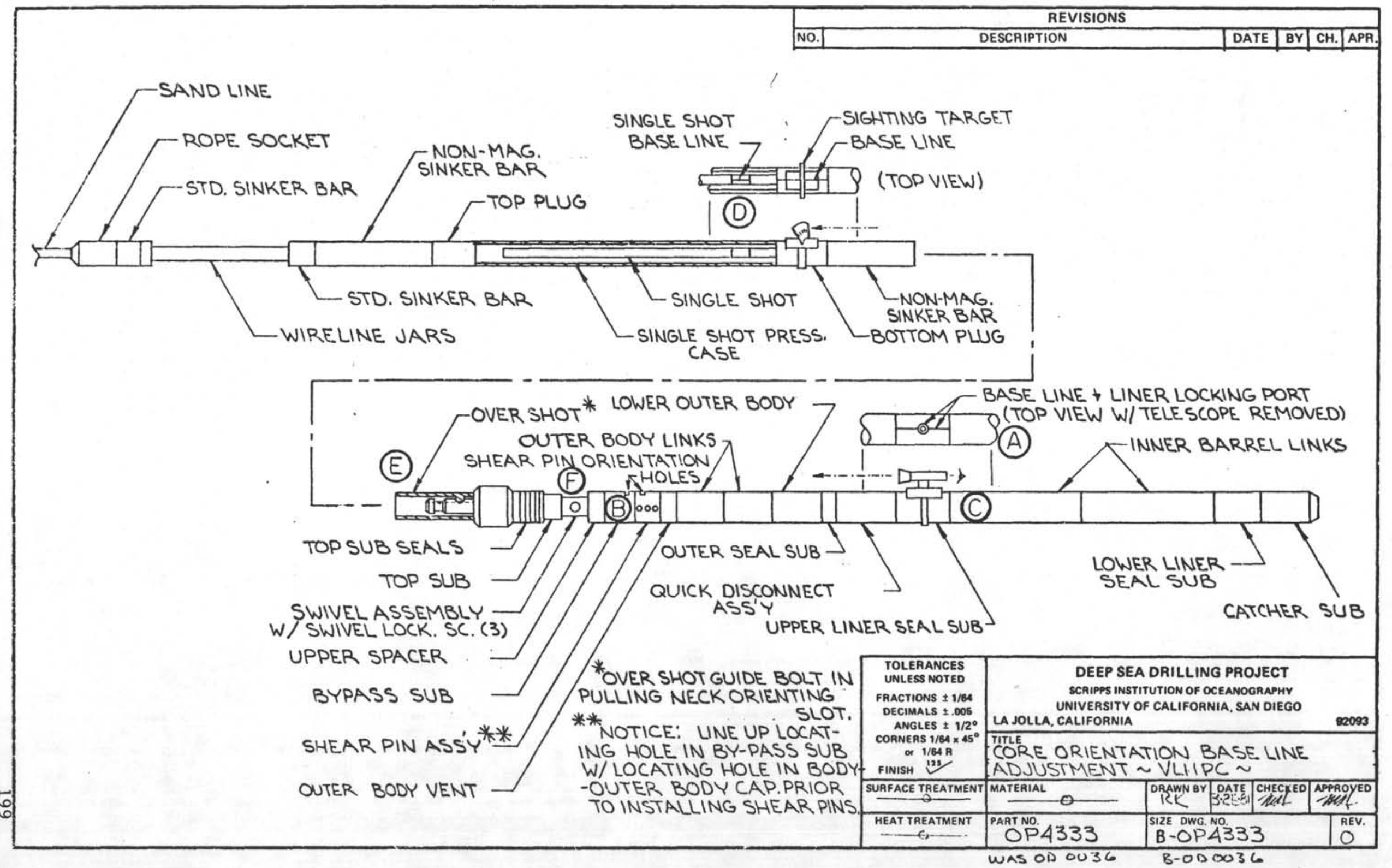




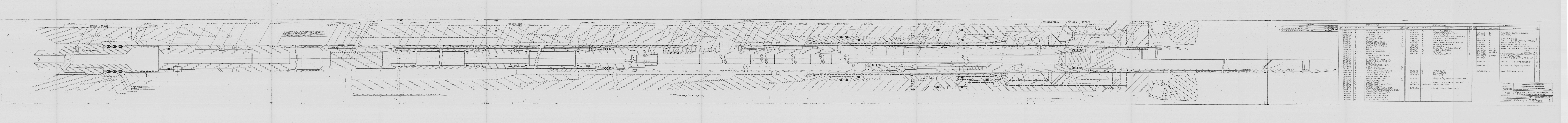


